
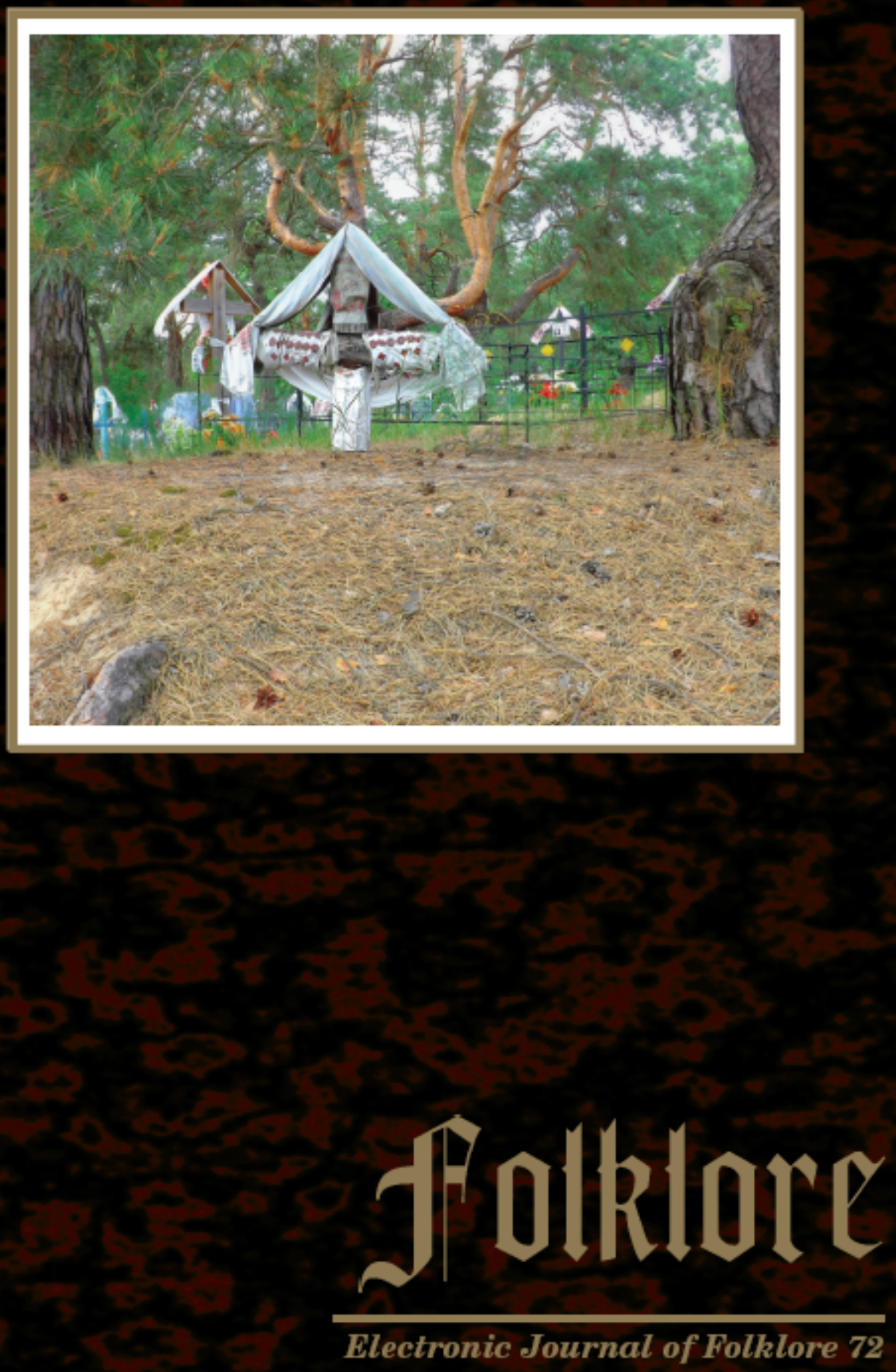


\section{Folklore}

Electronic Journal of Folklore

http://www.folklore.ee/folklore Printed version

Vol. 72

2018 
Folk Belief and Media Group

of the Estonian Literary Museum

Estonian Institute of Folklore

\section{Folklore}

Electronic Journal of Folklore

Vol. 72

Edited by Mare Kõiva \& Andres Kuperjanov

Guest editor: Tatsiana Valodzina

ELM Scholarly Press

Tartu 2018 


$\begin{array}{ll}\text { Editor in chief } & \text { Mare Kõiva } \\ \text { Co-editor } & \text { Andres Kuperjanov } \\ \text { Guest editor } & \text { Tatsiana Valodzina } \\ \text { Copy editor } & \text { Tiina Mällo } \\ \text { News and reviews } & \text { Piret Voolaid } \\ \text { Design } & \text { Andres Kuperjanov } \\ \text { Layout } & \text { Diana Kahre }\end{array}$

Editorial board 2015-2020: Dan Ben-Amos (University of Pennsylvania, USA), Larisa Fialkova (University of Haifa, Israel), Diane Goldstein (Indiana University, USA), Terry Gunnell (University of Iceland), Jawaharlal Handoo (University of Mysore, India), Frank Korom (Boston University, USA), Jurij Fikfak (Institute of Slovenian Ethnology), Ülo Valk (University of Tartu, Estonia), Wolfgang Mieder (University of Vermont, USA), Irina Sedakova (Russian Academy of Sciences).

This issue was financed by the Foreign Ministry of Estonia through the Developmental Cooperation Programme (66-2015-A).

The journal is supported by the Estonian Ministry of Education and Research (IUT 22-5), the European Union through the European Regional Development Fund (Centre of Excellence in Estonian Studies), the state programme project EKKM14-344, and the Estonian Literary Museum.

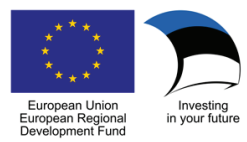

Indexed in EBSCO Publishing Humanities International Complete, Thomson Reuters Arts \& Humanities Citation Index, MLA International Bibliography, Ulrich's Periodicals Directory, Internationale Volkskundliche Bibliographie / International Folklore Bibliography / Bibliographie Internationale d'Ethnologie, Open Folklore, C.E.E.O.L., Scopus

\section{Editorial address:}

Folklore: Electronic Journal of Folklore

Vanemuise 42-235

51003 Tartu

Estonia

phone: $\quad+3727377740$

fax: $\quad+3727377706$

e-mail: folklore@folklore.ee

home page: http://www.folklore.ee/folklore

All rights reserved

(C) Estonian Literary Museum

Estonian Institute of Folklore

Authors

Design Andres Kuperjanov

According to Creative Commons licence BY-NC-ND 4.0

ISSN 1406-0957

doi:10.7592/FEJF2018.72 


\section{CONTENTS}

$\begin{array}{ll}\text { Introduction: Belarusian Folklore Studies } & 7\end{array}$

Tatsiana Valodzina

Reflexes of Ancient Ideas about Divine Twins

15

in the Images of Saints George and Nicholas in Belarusian

Folklore

Siarhei Sańko

On the Borders of Ethnolinguistic Equivalence:

Belarusian-South Slavic Parallels

Nikolai Antropov

Contemporary Recordings of Belarusian Folk Biblical and

Non-Biblical Etiological Legends in the Comparative-Historical

Aspect

Elena Boganeva

The Norm and Its Deviations in the Context of Childhood

Semiotics: The Belarus Tradition against the Slavonic

Background

Tatsiana Valodzina

Worldview of Belarusian Folk Song Lyrics

Yanina Hrynevich

The Pleiades in the Belarusian Tradition: Folklore Texts and

Linguistic Areal Studies

Tsimafei Avilin

The Problems Associated with Studying Folk Verse

Jury Paciupa 
From the Editorial BoArd

Patriotism and Love in the Context of the Estonian

Western Diaspora

Triinu Ojamaa

Continuity and Revitalisation in Sacrificial Rituals

203

by the Eastern Udmurt

Part I. The Collective Sacrificial

Rituals by the Bashkortostan Udmurt: Rooted in Tradition

Eva Toulouze, Ranus Sadikov, Laur Vallikivi,

Liivo Niglas, Nikolai Anisimov

INTERVIEW

Humor Makes Life More Tolerable. Interview with American

Folklorist Trevor J. Blank

Henri Zeigo

News IN BRIEF

Folklorists as Partners in an International Cooperation Project of Sustainable Rural Tourism. Reet Hiiemäe

International Conference of Humour Researchers in Tallinn. Piret Voolaid,

Liisi Laineste

Book Review

A Study of Human-Nature Relations. Anna Sirina 


\title{
INTRODUCTION: BELARUSIAN FOLKLORE STUDIES
}

\author{
Tatsiana Valodzina \\ Center for Belarusian Culture, Language and Literature Research \\ National Academy of Sciences, Belarus \\ e-mail: tanja_volodina@tut.by
}

In the centre of Europe, at the crossroads of its eastern and western cultural movements, as a result of a long-lasting and complex development, a unique culture of the Belarusian people was formed, which constitutes an integral part of modern civilization. As researchers claim, the national character and mentality of native Belarusian people (primarily, residents of rural areas) involve as one of the dominant features guidance by the cultural tradition, by which they mean the tactics (programme) of action which, on the one hand, contributes to the realization of this uniqueness and dissimilarity from other peoples, and, on the other hand, ensures stability, sustainability, ability to keep spiritual balance, and welfare in life.

Deep addiction of native Belarusian people to the customs and culture of their ancestors has been critical in determining one of the distinguishing features of this culture - the preservation of its root layer and its current topicality. Against the background of the general European cultural landscape, Belarus can rightfully be called a cultural reserve, since it is here that the oldest forms of folk art continue existing in rural life in their authentic form as a living proof of the life of the creative genius of one of the old Slavonic nations of Europe. (Encyclopaedia 2005: 4)

Belarusian folklore is primarily studied by the research fellows of the Institute of Art Study, Ethnography and Folklore of the National Academy of Sciences of Belarus. From the very beginning when the Institute was established (1957), the study of the problems of Belarusian oral poetic art and its linkage to the folklore of other peoples, literature, and the study of ethnic musical peculiarities was among the priorities. The collection of materials of different folklore genres, recording rituals, folk traditions, and melodies was considered to be of 
the utmost importance. The records of the Institute's research fellows as well as materials of some other folklorists who worked as correspondents directly from villages are kept in the Folklore Archive of the Institute.

Belarusian folklore researchers theoretically interpret the rich spiritual legacy of the Belarusian people and study modern folklore processes. Special attention is paid to the study of the genesis, content in terms of ideas and topics, poetics of individual genres and types; also comparative analysis of folklore works about Slavonic peoples is performed. In each of those directions many researchers, such as Piotr Hliebka, Alena Alfiorava, Halina Bartashevich, Tatsiana Valodzina, Tamara Varfalamiejeva, Uladzimir Vasilievich, Mihail Hrynblat, Yanina Hrynevich, Anton Hurski, Kanstantsin Kabashnikau, Tatsiana Kukharonak, Arsen Lis, Zinaida Mazhejka, Leanila Malash, Aliaksandr Marozau, Halina Piatrouskaja, Tatsiana Rabiets, Uladzimir Sivitski, Lija Salaviej, Vasil Skidan, Uladzimir Sysou, Halina Taulaj, Aliaksandr Tsitaviets, Ivan Tsishchanka, Tatsiana Tsiapkova, Anatol Fiadosik, Kanstantsin Tsvirka, Volha Sharaja, Viktar Jalatau, and others have worked and still do. Considerable attention is paid to the study of the history of Belarusian folk art and the history of folklore research. A joint monograph, Bielaruskaja narodnaja vusna-paetychnaja tvorchasc: Historyka-tearetychnaje dasliedavannie (Belarusian Oral Folk Art: Historical and Theoretical Study) (1967), joint publications Bielaruskaja falklarystyka: Zbirannie $i$ dasliedavannie narodnaj tvorchasci 60-h. XIX-pach. XX st. (Belarusian Folklore Science: Collection and Study of Folk Art of the 60s of the Nineteenth-Early Twentieth Centuries) (1989), Bielaruskaja falklarystyka: Epocha fieadalizmu (Belarusian Folkloristics: The Epoch of Feudalism) (1989), and Anatol Fiadosik's Bielaruskaja savieckaja falklarystyka (Belarusian Soviet Folkloristics) (1987) are dedicated to these problems. Monographs on different types and genres of folklore, their poetics and artistic peculiarities have also been published. A group of authors has prepared and published six books of the series Bielaruski falklor: Zhanry, vidy, paetyka (Belarusian Folklore: Genres, Types, Poetics) (2001-2004). ${ }^{1}$ The historiography of the Belarusian folklore research, its genesis, peculiarities of reality reflection, functionality, the system of images, and poetics of basic folklore genres are studied by a group of authors in volume seven of the series Bielarusy (Belarusians), under the heading Vusnaja paetychnaja tvorchasc (Oral Poetic Art) (2004).

Comparative studies of the folklore of Slavonic peoples are in the focus of attention in the books by Halina Bartashevich, Lija Salaviej, and Kanstantsin Kabashnikau, in a joint paper "Uzrouni ahulnasci falkloru uschodnich slavian" (The Levels of Unity of Eastern Slavs' Folklore) (1993), and in collections of articles by V. Jalataŭ, Piesni uschodnieslavianskaj ahulnasci (The Songs of Eastern Slavonic Community) (1977), and in the book titled Bielaruska-polskija kul- 
turnyja suviazi (Cultural Contacts between the Belarusian and Polish Cultures), edited by S. Martseleŭ (1991). The evolution of the national musical folklore science is researched in the book Bielaruskaja etnamuzykalohija: Narysy historyi (XIX-XX st.) (The Belarusian Ethnomusicology: Historical Essays (19th20th cc.)) (1997). The ethnomusicologists of the Institute have published regional collections of Belarusian folk songs, such as Piesni Bielaruskaha Paazierja (The Songs of Belarusian Poozerija) (1981), Piesni Bielaruskaha Paliessia (The Songs of Belarusian Polissya) (ed. 1 1983-1984), Piesni Bielaruskaha Paniamonnia (The Songs of Belarusian Neman River Basin) (1998), and Piesni bielaruskaha Padniaprouja (The Songs of Belarusian Dnieper River Basin) (1999).

Over the last decade theoretical folklore studies have been enriched through the use of modern methods of study, and a comprehensive approach to considering folklore facts. The scholarly paradigm of folkloristics (as a discipline studying traditional forms of lore) has undergone serious changes. In modern studies folklore is interpreted not only as an aesthetic phenomenon but also as a complex of important worldview and social and ideological functions. After a comprehensive consideration of the basic genres (separate monographs are dedicated to the description of most of them) folklorists have started researching the codes of the folklore model of the world of the Belarusian people. Over the last years, theses have been submitted, and a whole range of publications on separate codes have appeared - on dendrology (Ina Shved), ethnoastronomy (Iryna Malashuk, Tsimafei Avilin), subject matter and somatic code (Tatsiana Valodzina), vegetative (Uladzimir Sivitski), ornithology (Maryna Kamarova), and zoomorphic (Iryna Vyrva). Value and regulatory aspects of worshipping ancestors are in the focus of attention of Volha Sharaya's monograph.

Prior to the year 2000, an understanding of folklore as oral folklore, word art, etc. prevailed in the Belarusian scholarly tradition. In keeping with this understanding, the Belarusian folklorists started the new millennium with serious achievements - nearly fifty volumes of the series Belaruskaia narodnaia tvorchasts' (Belarusian Folklore), which contained almost all the basic genres of oral folklore, six generalizing books of the series Bielaruski falklor: Zhanry, vidy, paetyka (Belarusian Folklore: Genres, Types, Poetics) (2001-2004), and a two-volume encyclopaedia Bielaruski falklor (Belarusian Folklore) (20052006). Research into folklore by the traditions of philological folklore studies based on valid records of classical folklore of the nineteenth - the second half of the twentieth century in a way summed up the preliminary accumulation and interpretation of the material.

At the beginning of 2000 , the trend to consider textual complexes not in their genre relations, but as a complicated system of codes, the logical interpretation of which leads to tracing and description of contents important for 
the culture, regardless of the form or substance in which they are expressed, became obvious. The following codes started to be described to a certain extent: the spatial-landscape code, astronomy, ornithology, subject matter and somatic, and animalistic; in a particularly detailed way, the dendrology and coloristic codes were described in the papers by Ina Shved (Kosmas i chalaviek $u$ dendralahichnym kodzie bielaruskaha falkloru (The Space and Humans in the Dendrology Code of the Belarusian Folklore) (2006); Mifalohija kolieru u bielaruskaj tradycyjnaj duchounaj kultury (The Mythology of Colour in the Belarusian Traditional Spiritual Culture) (2011)).

Attention is already paid not to a specific genre or even text of oral poetic art, but to a unit of the symbolic language of culture. Therefore, the publication of the encyclopaedic dictionary Mifalohija bielarusau ${ }^{2}$ (The Mythology of the Belarusian People) (2011) was absolutely logical. The mythology and poetic picture of the ethnos's world were represented in almost one thousand articles, which were grouped into approximately fifteen basic codes, establishing its inner structure by topics.

Slow but confident dissemination of the ideas of anthropological folkloristics at the beginning of the third millennium is already bearing its fruit. Monographs are published in which semiotic and culture studies as well as other methods of folklore research add up to traditional philological methods. The monograph by Uladzimir Sivitski titled Rusalnaja tradycyja bielarusau: Mifapaetychnaja sistema, typalahichnyja paralieli (The Mermaid Tradition of the Belarusian People: Mythology and Poetic System, Typology Parallels) (2006) reconstructs the mythological model of the Russian tradition of the Belarusian people against the general Slavonic background. It suggests the concept of a genetic connection of the mermaid phenomenon to purely vegetative cult, and studies the natural and philosophical and, in fact, agrarian pragmatics as well as its calendar temporal determination. The monograph by Tatsiana Valodzina, Ciela chalavieka: Slova, mif, ritual (Human Body: Word, Myth, Rite) (2009) is dedicated to the image of a 'physical human', as well as ethnic medicine as one of the forms of interpreting the world and humans in it. Ethnic anatomy and ethnic medicine of the Belarusian people are represented as a fragment of traditional spiritual culture which is well-preserved, logically structured, full of mythological meanings and extremely rich in specific folklore manifestations.

The most significant trend in the current stage of development of the Belarusian folkloristics is the actualization of genres and types which used to be excluded from the domain to which professional research paid attention due to ideological considerations. A novelty is collections of the texts of the so-called Folk Bible, Bielaruskaja 'narodnaja Biblija' u suchasnych zapisach ${ }^{3}$ (The Belarusian 'Folk Bible' in Modern Records) (2010), and Zhorstki ramans: Falklornyja 
piesni $^{4}$ (Heart-Rending Romance: Folkloric Songs) (2010). The appearance of the 'Belarusian collection' of the Folk Bible prepared by Alena Bohanieva was a very timely and important event for specialists in the field of folklore text studies and non-fantastic prose, since this edition puts new extensive authentic material into scholarly circulation and represents the Belarusian folklore tradition in all its regional diversities.

The monograph by the ethnologist Uladzimir Lobach, titled Mif. Prastora. Chalaviek: Tradycyjny kulturny landshaft bielarusau u siemijatychnaj pierspiektyvie (Myth. Space. Human: Traditional Cultural Landscape of the Belarusian People in the Semiotic Perspective) (2013) is dedicated to the semantics and ritual functionality of the basic elements of traditional cultural landscape of the Belarusian people of both natural and anthropogenic origin in the system of their contacts and relations. On the basis of a wide range of ethnographic, folkloric and linguistic data as well as on the basis of his own field records, Uladzimir Lobach also characterizes cosmological parameters of the living space of the Belarusian people, which are shown in all the manifestations of the traditional culture of the ethnos. In the focus of consideration are the basic spatial and simultaneously axiological parameters of the Belarusian model of the world the ethnical territory represented in all the integrity of its taxonomic levels in the mythological and poetical world picture.

So far, as a rhetorical figure in all possible scholarly forums and, in particular, in popular science editions, a statement is expressed about the extraordinary richness of Belarusian folklore on the European scale, preservation of archaic beliefs, and special vitality of its basic forms. And with all its pathos, the statement is well-grounded since the classical peasant culture has really been preserved in the villages of Belarus in its authentic form, although in some cases passively (and each year faces irretrievable losses in its completeness and integrity). Therefore, Belarusian folklorists' most important direction of work is still the recording of the folk heritage, identification of the specifics of daily life and typology of the main types and genres, determination of the areals of song melodies, dances, plots, motifs, and images, and preparation of collections revealing the richness of the cultural landscape of the Republic of Belarus in its regional and local peculiarities.

Definitely, an event of importance was the publication of the series Tradycyjnaja mastackaja kultura bjelarusau (Traditional Artistic Culture of the Belarusian People) (2001-2013) in 6 volumes (ten books), the author of the idea as well as the compiler and scholarly editor of which was Tamara Varfalamiejeva. This collection is extremely rich in records of the texts made over the last decade; it constitutes a sample of a comprehensive study of the artistic tradition of the region, which represents calendar and family rituals 
and rites, non-ceremonial lyrics and instrumental music, dancing folklore, folk games, folk prose, small genres, spells, traditional costumes, and folk textile. The last three volumes were published with electronic appendices: records of authentic songs, instrumental music and folk prose performed by charismatic singers, instrumental music players, and story-tellers. Authenticity of the texts, accurate rendering of dialectal peculiarities, and individual speech manner of the informants, attention to the context and personal emotional experiences of the tradition bearers, and a wide regional coverage of materials create a largescale panorama of the daily life of the Belarusian traditional culture in its current stage. The corporate authors (Alena Bohanieva, Tamara Varfalamiejeva, Tatsiana Valodzina, Tatsiana Kukharonak, Volha Labacheuskaja, Mikalaj Kozienka, Iryna Smirnova, and others) are trying to show the vitality of ethnic culture and folklore.

Among the compilers and publishers of the Belarusian folklore, we may distinguish articles and collections by Henadzi Lapatsin from the Vetka Folk Art Museum, who is well-known by his publications in the Zhiva Starina, Antropologicheskiy Forum, Paleoslavica, and many conference collections and materials.

The publication of the texts in recent years, and scholarly approaches applied by their authors and compilers once again convince us that the division of culture into 'material' and 'spiritual' is disappearing, and the human being rises into the centre of attention. Field interviews, talks with local residents, extended stories told by informants which naturally go beyond the limits of the genre classification of folklore and mainly constitute evaluations, considerations, and conclusions, start showing their advantages. Such texts are particularly valuable in terms of the representation of the world outlook and serve as a reliable source for researching the current state of the traditional Belarusian culture.

Though some publications, mostly descriptive and informative ones, are available, urban, student, soldier, criminal, and other kinds of folklore still remain a closed area for the Belarusian folklore studies. There are a couple of reasons for that: an extensive field for collecting and interpreting keeps offering traditional and village folklore, almost every expedition provides new, sometimes unique findings which are waiting for their scholarly identification and their turn to be included in the system; the Russian nature of the urban folklore and post-folklore demonstrates itself here, which is partially why it is sometimes rejected; the absence of not only a respective school in the country but any generalizing works of a methodological nature (which, naturally, stem from the above reasons). The effort of scholars focuses on the development of an adequate set of tools not only for the study of the current state of tradition but also for the determination of the peculiarities of the effect the mythological 
models of folklore produce by means of reality interpretation, including interpretation by townspeople.

The most promising plans of the Belarusian folklorists and ethnolinguists include the compilation of the Belarusian Folklore and Ethnolinguistic Atlas (BFELA) launched by the sector of ethnolinguistics and folklore of the Centre for the Belarusian Culture, Language and Literature, under the supervision of Mikalaj Antropau and Tatsiana Valodzina. The BFELA, by its sense, the principles of its organization, objectives and tasks, shall act as a description of the traditional spiritual culture of the Belarusian people, systematized primarily on the basis of expedition data, generalized on the level of typologically significant features, and implemented in the form of maps with extended legends. The atlas will contain a detailed and consistent description of all the important meaningful elements of folklore culture of typological value, which are sustainably reproduced in a certain form characteristic of each given tradition.

Launching of a periodical - an annual collection of scholarly articles under the heading Bielaruski falklor: Materyjaly i dasliedavanni (Belarusian Folklore: Materials and Studies) has been a long-awaited and perspective event. Three issues of it have been published (2014-2016). The periodical has already outlined the range of topics and research priorities of the Belarusian folklorists as well as introduced into the scholarly circulation a considerable amount of authentic materials not published before. The edition has already become a fruitful and interesting platform for discussing topical problems of folklore studies.

\section{ACKNOWLEDGEMENTS}

The article was written as part of a project financed by the Foreign Ministry of Estonia through the Developmental Cooperation Programme (66-2015-A).

\section{NOTES}

1 Book 1. Arsen Lis et al. Kaliandarna-abradavaja paezija (Calendar Ritual Poetry), edited by Anatol Fiadosik (Minsk 2001); Book 2. Anatol Fiadosik \& A. Jemialjanau \& Uladzimir Sysou \& Mihail Kaladzinski. Siamiejna-abradavaja paezija: Narodny teatr (Family Ritual Poetry: Folk Theatre) (Minsk 2001); Book 3. Anton Hurski \& Halina Piatrouskaja \& Lija Salaviej. Pazaabradavaja paezija (Non-Ritual Poetry) (Minsk 2002); Book 4. Kanstancin Kabashnikau \& Anatol Fiadosik \& Aliaksandr Tsitaviets. Narodnaja proza (Folk Prose) (Minsk 2002); Book 5. Aliaksiej Nienadaviec et al. Mifalohija: Duchounyja viershy (Mythology: Spiritual Poems) (Minsk 2003); Book 6. Tatsiana Valodzina et al. Malyja zhanry: Dziciachy falklor (Small Genres: Children's Folklore) (Minsk 2004). 
${ }^{2}$ Mifalohija bielarusau: encykl. sloun (The Mythology of the Belarusian People: Encyclopaedic Dictionary). Compiled by Iryna Klimkovich \& Viktar Autushka; edited by Tatsiana Valodzina \& Siarhiej Sanko (Minsk 2011).

3 Introductory article, compilation and commentary by Alena Bohanieva.

${ }^{4}$ Compiler and author of the introductory article A. Kukresh.

\section{REFERENCES}

Encyclopaedia 2005 = Bielaruski falklor: Encyklapiedyja (u 2 t.). [Belarusian Folklore: Encyclopedia (in 2 vols.).] Minsk: Bielaruskaja encyklapiedyja. 


\title{
REFLEXES OF ANCIENT IDEAS ABOUT DIVINE TWINS IN THE IMAGES OF SAINTS GEORGE AND NICHOLAS IN BELARUSIAN FOLKLORE
}

\author{
Siarhei Sańko \\ Institute of Philosophy \\ National Academy of Sciences, Belarus \\ e-mail: siarhey.sanko@gmail.com
}

\begin{abstract}
As the images of Saint George and Saint Nicholas in Belarusian folklore converged, forming a non-canonical pairing, they assimilated a number of features indicative of an earlier tradition of divine twins' veneration. Specifically, the paper focuses on the following features: 1) the possible traces of the devatādvandva grammatical form and the dual number; 2) a special attitude towards horses; 3) Saints George and Nicholas accompanying (in the capacity of charioteers) a female deity or a mythological creature (Blessed Mother, Aurora); 4) Saints George and Nicholas accompanying a character who inherits the Thunderer's features (Saint Elijah, Saint Michael the Archangel); 5) systematic differences within a pair when one of the members is portrayed as a young man (Saint George) and the other one as an old man (Saint Nicholas); 6) the duplication of a single saint's image; 7) narratives of twin healers, one of whom functions as a surgeon and the other one as a thaumaturge.
\end{abstract}

Keywords: myths about twins, divine twins, paired saints, Saints George and Nicholas, twin healers

Grouping saints in pairs is a feature found in many European traditions. As early as the nineteenth century, Charles Cahier described different ways of grouping saints in Western European folk art and offered examples of paired saints (Cahier 1867: 453-463) and triads of saints (ibid.: 433-467). It is notable that the former are considerably more frequent than all the other grouping types (three, four, five, etc.). In a later analysis of saints' groupings in Celtic Christianity, Gilbert Doble argued that "there are numerous cases of dedications to Celtic saints being found in pairs. Thus dedications to S. David adjoin those to S. Nonna, while S. Winnow and S. Nectan, S. Mewan and S. Austol, S. Kea and S. Fili, S. Brioc and S. Marcan, seem to be always associated with each other" (Doble 1935: 43). He also suggested an alternative list of paired saints 
and noted that "the joint cult of SS. Mewan and Austol is a particularly striking example of this phenomenon" (Doble 1939: 16). The discussion of Celtic data can be found in Jankulak (2013 [2009]). A century ago, James Rendel Harris also suggested a connection between paired saints in European folklore and apocryphal literature with the ancient cult of "heavenly twins" (Harris 1903, 1906, 1913).

The same phenomenon of grouping saints existed in the cultural sphere of Russian Orthodoxy and sometimes manifested in canonisation (cf. the paired saints Anthony of the Caves and Theodosius of the Caves). This tendency is even more prominent in "folk Christianity" and is reflected in folklore texts of different genres. It is noteworthy that such grouping is often either entirely or mostly independent from both canonical and apocryphal hagiography. This tendency could not have been related to the spread of Christianity in Eastern Europe because it was not so prominent in the Byzantine Empire, where it stemmed from a persistent tradition of worshipping divine twins, which itself originated in the Greco-Roman world.

A prominent case of a saint pairing without a strong hagiographic influence in Belarusian folklore is the pair of Saints George and Nicholas. ${ }^{1}$ These saints invariably appear together in a vast body of folk charms which include enumerations of saints (often according to the folk calendar) and canonical saint pairings (Saints Cosmas and Damian, Florus and Laurus, Peter and Paul, Anthony and Theodosius, etc.), for example: “... Kuźma-Dziemian, ... Jahorja, i Mikola, ... Piatra-Paŭla, ...” (... Cosmas-Damian, ... George, and Nicholas, ... Peter-Paul, ...) (Romanov 1891b: 27, No. 90); “... śviatyj Jurij i śviatyj Mikola, i śviatyj Pavla j Piotra" (... Saint George and Saint Nicholas, and saints Paul and Peter) (ibid.: 77, No. 146); "Śviaty Jura, śviaty Mikola, i śviaty Antonij i Chviadosij, Illia i Pakrova" (Saint George, Saint Nicholas, and saints Anthony and Theodosius, Elijah and Pakrova $^{2}$ ) (Bartaševič 1992: 47, No. 61); "Śviaty Božy dzianiočak, Śviataja Subota, Śviataja Sluckaja Troica, Śviaty Ajciec Mikola, Śviaty Jurej-uhodničak Božy” (Holy God's Day, Holy Saturday, Holy Slutsk Trinity, Holy Father Nicholas, Saint George - God's chosen one) (Vasilievič \& Salaviej 2009: 200, No. 917).

It is interesting to note that the following features are not typical of the Russian tradition of charms: 1) enumerating saints in a calendar sequence (cf., for example, Maykov 1869: 76, No. 195; 114-115, No. 285; Vinogradov 1907: 53, No. 70; Vinogradov 1908: 23, No. 13; Vinogradov 1910: 8-9) and 2) grouping saints George and Nicholas even in a positional pair. Moreover, when George and Nicholas's names are listed in an enumeration not far from each other, they may be separated by some other saint or saints: 
Istinnyi Khristos i Bogoroditsa, Mater' Bozhiya, Mikhaile i Gavriile Arkhangeli Gospodni, Nikolae Chudotvorets, Vlasie, Sevatiyskii chyudotvorets, Georgie Khrabryi, Flore i Lavre, Merkurie Smolenskii, Averkii Yerapol'skii, Antonii, Feodosii Kiyevskie Pecherskie chyudotvortsy... (Vinogradov 1907: 53, No. 70)

True Christ and Dei Genetrix, the Mother of God, Michael and Gabriel the God's Archangels, Nikolaos the Wonderworker, Blaise the Wonderworker of Sebastea, George the Brave, Florus and Laurus, Mercury of Smolensk, Abercius of Hieropolis, Anthony, Theodosius of Kiev the Wonderworkers of the Caves...

Stoit velikii Nikolae Chyudotvorets ... Na gorakh kamennykh stoyu ya, rab bozhii (imya rek), poklonyayusya na vse chetyre storony Isusu Khristu, Vyshnemu Tvortsu, $i$ Khrabromu Georgiyu, $i$ arkhistratigu Mikhailu, i vsem nebesnym silam, Gavriilu i Koz'me i Domiyanu, i arkhidiyakonu Stevanu, i svyatym apostolom Petru i Pavlu, $i$ vsem svyatym apostolom. (Vinogradov 1908: 45, No. 42)

Great Nikolaos the Wonderworker is standing... I, God's slave (name), am standing on the stone rocks, bowing at all the four sides to Jesus Christ, Supreme Creator, and George the Brave, and Michael the Archistrategos, and all the powers of heaven, Gabriel and Cosmas and Damian, and Stephen the Archdeacon, and Saint Apostles Peter and Paul, and to all the Saint Apostles.

Umolyayu Tebya, istinnyi Khristos, Syn Bozhii, vsemiloserdnyi Bozhe, i Mater' Presvyataya Bogoroditsa, i svyatyi arkhangel Mikhail, groznyi voyevoda nebesnykh sil, svyatyi Georgii Khrabryi, i svyatye ugodniki Kossma i Damian, Nikolai chudotvorets, Vlasii, yepiskop Medostii Iyerusalimskii, Frol i Lavr, Merkulii Smolenskii, Averkii Iyerapol'skii, $i$ svyatye yevangelisty Matvei, Ioann, Luka $i$ Marko, $i$ svyatye ugodniki Antonii i Fedosii, kiyevskie chudotvortsy, kheruvimy $i$ serafimy $i$ vsya nebesnyia sily! (Maykov 1869: 114-115, No. 285).

I beg you, True Christ, the Son of God, God the All-Merciful and Holy Mother of God, and Saint Michael the Archangel, formidable commander of Heaven's forces, Saint George the Brave, and Saints Cosmas and Damian, Nikolaos the Wonderworker, Blaise, bishop Modestus of Jerusalem, Florus and Laurus, Mercury of Smolensk, Abercius of Hieropolis, and Saint Evangelists Matthew, John, Luke and Mark, and Saints Anthony, Theodosius the Wonderworkers of Kiev, cherubim, seraphim, and all the powers of Heaven! 
It should be noted here that academic discussion of the merging cults of the two saints was primarily based on Belarusian data (Anichkov 1892: 39-40; Uspenskiy 1982: 138-140). The repositories of paired saints in Belarusian and Russian charms overlap only partially. This could mean that the phenomenon of grouping saints in pairs continued into the period of Russian and Belarusian Orthodoxies' independent existence on ethnic Russian and Belarusian territory (at least, into the times of the Grand Duchy of Lithuania and the Polish-Lithuanian Commonwealth).

Saints George and Nicholas are much more often called upon together beyond these enumerations (see, for example, Romanov 1891b: 18-19, No. 50; 43, No. 158 ; 43, No. $160 ; 47$, No. 174 ; 82 , No. 168 ; 112 , No. 297 ; 137 , No. 2 ; 138 , No. 4; 139, No. 10; Bartaševič 1992: 56, No. 90; 62, No. 109; 64, No. 116; 65, No. 118; 344, No. 1185; Vasilievič \& Salaviej 2009: 199, No. 912; 200, No. 917; 471, No. 2323; 503, No. 2497).

If a saints' trio is called upon in a charm, then two of them generally appear as a pair in other cases. Saints George and Nicholas can be coupled with Saint Michael the Archangel in Belarusian charms: "śviatoha Jahorija ... śviatoha Mikalaja ... śviatoha Michajla" (Saint George ... Saint Nicholas ... Saint Michael) (Romanov 1891b: 183, No. 98; another variant in Vasilievič \& Salaviej 2009: 140, No. 606; 493, No. 2450), Saint Elijah: "Śviaty Mikola, Śviaty Juraj, Śviaty Illia" (Saint Nicholas, Saint George, Saint Elijah) (Vasilievič \& Salaviej 2009: 81, No. 274), and Holy Mary: "Śviaty Juraj, śviataja Mikola, matka Chrystova" (Saint George, Saint Nicholas, the Mother of God) (Bartaševič 1992: 312, No. 1051); "Śv. Jury, Śv. Mikola, matka Pakrova" (Saint George, Saint Nicholas, the Mother Pakrova) (Vasilievič \& Salaviej 2009: 265, No. 1230). There is a curious case when "Zaranica" (Aurora) takes the place of a female character: "Išoŭ śviaty Juraj ź Mikolam, stračaje zarnicu" (Saint George was walking with Saint Nicholas and met Aurora) (Bartaševič 1992: 344, No. 1185).

Saints George and Nicholas also appear together in Belarusian traditional calendar poetry: "Jurja i Mikola pa miežach chodziać, / Pa miežach chodziać, žyta rodziać" (George and Nicholas walk along the field edges / [They] walk along field edges, make the rye grow) (Bartaševič \& Salaviej 1980: 101, No. 61); “[Haspadar] Siadlaje kania vorana, / Jedzie ŭ polie žyta hliadzieć. / Spatykaje jaho Jurje ź Mikolaj: / - Nie jedź, panie haspadaru, / Tvajo žyta daŭno ahliedžana..." ([The master] saddles up a black horse, / Rides to the field to inspect the rye. / George and Nicholas meet him: / - Don't go, master, / Your rye was inspected long ago...) (Bartaševič \& Salaviej 1980: 87, No. 45); “Jurje, Mikola, / Abyjdzi žyta naŭkola, / I adamkni ziamlicu, / I vypuści rasicu” (George, Nicholas, / Walk around the rye, / And unseal the land, / And let the dew out) (Bartaševič \& Salaviej 1979: 173, No. 196); "A ty, Yurja, Mikola, / Abyjdzi žyta naŭkola" 
(And you, George, Nicholas, / Walk around the rye) (Bartaševič \& Salaviej 1979: 173, No. 195). Moreover, in the extensive body of Belarusian valačobnyja ${ }^{3}$ songs the plot revolves around the search for a missing fertility deity, a motif better known from surviving Hittite variants (Sańko 1994). In approximately half of the songs one of these paired saints (either George or Nicholas) represents the "fertility deity", while the other one tends to be the only character who is able to find the missing protector of good harvest and prosperity in the coming calendar cycle.

Saints George and Nicholas are portrayed as paired saints in a number of folk legends (Sheyn 1893: 360-362, No. 210; 367-370, No. 215; Romanov 1891a: 19-20, No. 15; 20-22, No. 15b; 66-67, No. 44; 163-165, No. 16). They also feature in proverbs related to the calendar cycle: "Jury z rasoj, a Mikola ź siaŭboj" (George is with the dew and Nicholas is with the sowing) (Fiadosik 1976: 99, No. 637); "Jury ź ciaplom, a Mikola z karmom" (George is with the warmth and Nicholas is with the fodder) (Fiadosik 1976: 99, No. 638); "Jury napjecca, i Mikola nie astajecca, da j Ivan by piŭ, kab chto kupiŭ" (George will get drunk, and Nicholas will follow him, and John would have drunk if someone had bought [him something to drink]) (Fiadosik 1976: 99, No. 639); "Skazaŭ śviaty Jurja: 'Ja žyty ǔradžu', a śviaty Mikola: 'Jak ja pahliadžu”' (Saint George said: 'I will grow rye' and Saint Nicholas [said]: 'As I will look after') (Fiadosik 1976: 99, No. 645); “Jury skazaŭ: 'Žyty ǔradžu'; Mikalaj adkazaŭ: 'Paždžy, pahliadžu"' (George said: 'I will grow rye' and Nicholas replied: 'Wait, I will look after') (Fiadosik 1976: 100, No. 645a); “Jury maścić, a Mikola hvaździć” (George makes it chilly, and Nicholas makes it frozen) (Fiadosik 1976: 113, No. 813); "Jury zamościć, Mikola zahruździć" (George will make it chilly, Nicholas will freeze the soil) (Fiadosik 1976: 113, No. 813a); "Viasnoju Heorhi, lietam Nikalaj z kormam, uvosień z mostam, zimoju z hvoździem" (In the spring it is George, in the summer it is Nicholas with fodder, with a chill in the autumn, with frost in the winter) (Fiadosik 1976: 113, No. 814), and also in ritual practices: "Na Mikolu kolas paśviačali, na Juryja - žyta” (On St. Nicholas's Day an ear [of rye] was consecrated, and on St. George's Day the [crop of] rye [was consecrated]) (Lopatin 2006: 294, No. 38).

One of the first scholars to investigate the reasons behind the convergence (up to the total merging) of the folk images of Saints George and Nicholas was Evgeniy Anichkov. He cited Saint Nicholas's “other vita” (Antonin 1873: 280; Leonid 1881: 61), which has an account of Saint Nicholas visiting Saint George's church and sacrificing oxen there (Anichkov 1892: 6), but he himself acknowledged the vulnerability of this evidence inasmuch as Saint Nicholas also visited other churches during his pilgrimage, where he also sacrificed oxen to other saints (ibid.: 7). What is more important is that hagiographic texts ascribed 
similar miracles to both saints (and also to Saints Nicetas and Theodore): the miracle of transference (delivering an enslaved young man from heathens), the miracle of prison liberation, the miracle of the servant who lost gold; although Anichkov ultimately argues that "this only proves the idea that the legends of Saints George, Theodore, Nicetas, and Nicholas developed in similar conditions" (ibid.: 9). Anichkov also noted that some stories about St. Nicholas incorporated the theme of dragon slaying (commonly associated with St. George).

Still, these similarities in most likelihood merely indicate what motifs were popular at the time when the respective vita variants emerged. Some of these motifs clearly are of pagan origin (including the dragon slaying).

It is likely that the real convergence of the images of these two saints occurred at the time of Ancient Rus'. The original variant of "Menology" that was included in the ancient Russian adaptation of the earlier Bulgarian "Streams of Gold" (Sreznevskiy 1867: 19-23, 26; Fomina 1984) includes a note that on 6 December (O.S.) there was "a miracle of Saint Nicholas and Saint Christian martyr George" (so-called "double miracle"), different versions of which subsequently became parts of various anthologies of Saint Nicholas's miracles (Makeyeva 2009). Turilov's idea that the "double miracle" had a Greek origin (that was transmitted via Bulgaria) (Turilov 1996) is still no more than a hypothesis, thus Uspenskiy's conclusion that the two saints' pairing is a uniquely Eastern Slavic phenomenon looks more plausible. This is all the more the case given that such merges are numerous and recurrent in folk culture and they are generally not motivated by a "double miracle" in theological and ecclesiastical literature.

It was already Anichkov who paid specific attention to Belarusian valačobnyja songs when discussing the reasons for the convergence of Saints Nicholas's and George's cults. He noted that "the performers of valačobnyja songs are of unsophisticated commoners: valačobniki who sang these songs on major holidays in front of houses' windows, of course, did not care to study the vita of a saint, but, on the contrary, sang about him what they learned from their immediate uneducated environment" (Anichkov 1892: 39). He also drew attention to the calendar proximity of the two saints' spring holidays and saw it as one of the reasons of their merging in folk tradition (ibid.).

I suggest that another important reason for this convergence both in charms and in folk songs was the older tradition of verbal and nonverbal veneration of "divine twins". So I consider it is necessary to focus on the possible traces of this twin mythology in the saints' images. Twin mythology was thoroughly discussed by James Rendel Harris (1906), Fernand Chapouthier (1935), Alexander Krappe (1936), Donald Ward (1968), Vyacheslav Ivanov and Vladimir Toporov (1983), and others. 


\section{POSSIBLE GRAMMATICAL INDICATORS OF SAINTS GEORGE AND NICHOLAS' PAIRING}

An analysis of ancient Russian literature shows that to designate special - "divine" or saint - pairs, forms of ancient dual number were used that are similar to what was known as devatādvandva (lit. "divine pair") in the ancient Indian language (Zholobov 1997, 1998; Zholobov \& Krys'ko 2001). In the Vedic tradition, it is extremely likely that it was the natural pairings of divine twins (such as Sky Father and Earth Mother, the Ashvins and Mitra-Varuna) that were originally referred to as devatādvandva in the Rigveda and the Atharvaveda (dyā'vāprthivī' 'Sky-Earth', mitrāvaruṇāu 'both Mitra and Varuna', aśvínāu 'both Ashvins'), which served as a model for similar references in other (originally non-twin) pairs. Oleg Zholobov argued that "when studying these facts, we cannot separate linguistic aspects from those of comparative mythology and the history of culture in general. In this particular case the interpretation of abovementioned illustrations as ancient Slavic examples of devatādvandva form corresponds entirely to their cultural status as venerated pairs. Nowadays we can consider it established knowledge that the pagan twin cult transformed into East and South Slavic veneration of sacred pairs" (Zholobov 1998: 51). This aspect was also highlighted by Vyacheslav Ivanov and Vladimir Toporov (Ivanov \& Toporov 1977: 115; Toporov 1989: 59-63 ff.).

Vitaliy Zaykovskiy emphasised that combining the saints' names into a single word (for example, Cosmas-Damian, Peter-Paul, Zosimus-Sabatius, GeorgeNicholas, etc.) in folklore texts reflects "the process of two names' integration into one devatādvandva-type name, a unified name that collocates with words in a singular form" (Zaykovskiy 1994: 56-59). In a paper on folk verses about Nikola Mokrush (St. Nicholas), Taisiya Khlybova tentatively suggested that the ancient literary dual number could have influenced the grammatical indicators of the feminine gender applied to male sacred characters: "In nominative, accusative and vocative cases of the dual number the declensional endings of masculine adjectives is "-as" (-aya) (for example: Raduytasya, Borise $i$ Glebe bogomudraya! <...> blazhennaya etc.), masculine verbs' dual number ends with the feminine inflexion - $a$ (nesla, khodila)." However, she ultimately favoured a different explanation of this phenomenon, saying: "In our opinion, the discrepancy between grammatical and natural gender in the verse is caused primarily by extralinguistic factors" (Khlybova 2007: 24). Six years earlier Svetlana Tolstaya had also highlighted this phenomenon:

The gender changes affected primarily male names of the feminine grammatical inflectional paradigm where a transfer to the feminine gender did not demand any formal modifications of the stem: 'Dve Mikoly u nas 
prazdnovali - zimnyaya i vesnovaya' (We celebrated two Nicholas's [days]: one in winter and one in spring), 'Varvara zavaryla, a Mykola zagvozdyla' (Varvara boiled and Nicholas froze), 'Svyataya Llya [Ilya]' (Saint Elijah), 'Llya nanesla gnillya' (Elijah brought rot), etc. (Tolstaya 2001: 57)

She noted that "they are a prominent testimony to the semantic disconnect between anthroponyms and original Christian reference; as a result, the category of the grammatical gender loses its real content (correlation with sex) and the anthroponym loses its onomastic function" (ibid.).

Such examples are indeed numerous in Belarusian folklore texts (Taisiya Khlybova cited primarily Belarusian examples). They mostly refer to Saint Nicholas (śviataja Mikola) and Saint Elijah (śviataja Illia), but can also be applied to Saint George's name: "Prošu ja i Jurju-Jahorju i Mikolu nadzieliajuščaho" (I also ask George and Nicholas the Giver) (Romanov 1891b: 48, No. 176). There is, however, one folk charm that most likely reflects the dual forms of masculine adjectives:

Śviaščennaja i votča načaĺnica Mikolaja, śviatyj božij uhodnik, vialikij čudotvorca, spasisia ob dušach našych. ... Śviatyj chrabryj Jahoraj, biari svoju zolotuju trubu ... Śviatyj prapodobnyj Chrolij, i ty žich spastyr, spasi jetu skocinu. Śviataja usierdnaja, $k$ vam pribehaju, Hospodi vyšnij Isusia Christe, synia božij, mać pračistaja, presviataja bohorodica. Śviataja mać pračistaja, spasi ž jetu skocinu ... I prosim śviatoho Mikolu, božaho uhodnička čudotvorca: śviatyj Mikola čudotvorac, spasi jetu skocinu... (Romanov 1891b: 46, No. 169)

Sacred and fatherly chief Nicholas, God's Saint, the great Wonderworker, take care of our souls ... Holy brave George, take your golden trumpet ... Saint Reverend Florus, you are their shepherd, take care of this stock. Holy zealous, I am turning to you, Holy God Jesus Christ, the Son of God, Blessed Mother, Our Lady, Holy Mother, save this stock ... And we ask Saint Nicholas, God's Saint the Wonderworker, to take care of this stock...

The charm's text is obviously contaminated with fragments of other charms used to strengthen the power of magical text. This is reflected in the double appeal to Saint Nicholas in different grammatical forms and the "incorrect" appeal to Saint Florus without mentioning Saint Laurus. The latter two saints only appear in charms as a pair. Thus we should attribute the words "Śviataja usierdnaja" (Holy zealous) to "Śviaščennaja i votča načaĺnica Mikolaja ... Śviatyj chrabryj Jahoraj" (Sacred and fatherly chief Nicholas ... Holy brave George), suggesting that the grammatical "incorrectness" reflects some formulas based on devatādvandva. This example is important because the name Nicholas does 
not fall into the feminine grammatical inflectional paradigm and, therefore, the usage of the feminine grammatical gender in this case ("Śviaščennaja i votča načaĺnica Mikolaja”) requires an alternative explanation to the one cited earlier by Svetlana Tolstaya. The suggestion that devatādvandva formulas might be reflected in this case could seem far-fetched were there no other hints of this ancient model's influence on the charms' texts. The folk image of paired saints Boris and Gleb is an interesting case. Strangely, while the pairing was very prominent in ancient Russian literary culture, it had almost no reflection in folk charms. This image is absent from Russian charms anthologies that were used for this study (by Maykov and Vinogradov), and its transformed variant is mentioned just twice in Belarusian texts and only in the enumerations that follow the calendar order (Romanov 1891b: 27-28, No. 90, 92). This means that the charms borrowed it from the folk calendar and not from the literary tradition. It is important that in both cases these paired saints are represented in the texts by only one of the brothers, Boris, whose name is pluralised: "Śviatyja Hanny, Borisa, Makavja - christovy dzianiočki" (Saint Anns, Borises, Maccabees - Christ's days) (Romanov 1891b: 27, No. 90); "pomolimsia śviatym Borisam, Hannam, Makavju, śviatomu Spasytalku...” (let's pray to Saints Borises, Anns, Maccabees, Holy Saviour ...) (Romanov 1891b: 28, No. 92).

In the first case the dual number (Borisa) is used, while in the second case it is plural (Borisam). This is reminiscent of the use of the elliptical dual number model to name divine twin pairs, dvandva ekaśeșa (Sanskrit ekaśeșa 'ellipsis') as in Vedic mitrā 'Mitra-Varuna' (lit. "both Mitras"). It could transform into plural if the dual number lost its independent grammatical meaning, for example, in Greek Aïavte "Ajaxes" (i.e., "Ajax (Aias) and Teucer"), Latin Castores (i.e., Castor and Pollux) and Cereres (i.e., Ceres and Proserpina) (Bremmer 2008: 60; Puhvel 1977: 404; Wackernagel 1905 [1896]: 151), cf. Latin patres and Belarusian baćkí where the elliptical dual number was replaced by plural. A similar form is presumed to have existed in the Hittite language. The elliptical dual number is not replaced mechanically by plural, but could be reinterpreted as single (Puhvel 1969: 61-62).

Therefore, it is logical to see the first example as an elliptical dual number and regard "Borisa" as "(oba) Borisa" (both Borises), i.e., Boris and Gleb. The inconsistency in transforming the dual number into plural, which was noted by Puhvel, may be at play in the cases when the Boris and Gleb holiday is referred to as a singular word, for example, Boris (Tolstaya 2005: 41).

This transformation and the interpretation of twin and divine pairs as a whole could have resulted in using the singular form in cases when SS. George and Nicholas act together: "Jurje, Mikola, / Abyjdzi žyta naŭkola, / I adamkni ziamlicu, / I vypuści rasicu" (George, Nicholas, / Walk around the rye, / And 
unseal the land, / And let the dew out) (Bartaševič \& Salaviej 1979: 172-173, No. 196, also No. 195). The same tendency can be observed in charms: “...budzia jechać śviaty Jury i Mikola, budzia vas sabirać i miečču halovy adsiakać” (Saint George and Nicholas will come, will call you together and cut the heads with a sword) (Bartaševič 1992: 125, No. 345).

\section{SS. GEORGE AND NICHOLAS' SPECIAL ATTITUDE TOWARDS HORSES}

It is well known that classical "divine twins" (the Greek Dioscuri and the Vedic Ashvins) had a special attitude towards horses:

In each of the Indo-European traditions, the association of the Divine Twins with the horse represents the most pronounced characteristic of the twin brethren. Moreover, the striking agreement in detail revealed by the various traditions makes it evident that this association dates back at least to the period of Indo-European unity. (Ward 1968: 11-12)

So it does not require any detailed additional comment.

Both George and Nicholas are regarded as the guardians of horses in folk culture. As a rule, on these saints' days in spring people tried to take their horses to the pasture for the first time either during the day ("na Jurjevu rasu"; "on George's dew”) or at night ("na Mikoĺskuju travu"; "on Nicholas's grass"). It depended on when spring started and on the proximity to the full moon. Belarusian valačobniki used to sing about it: "Kaniušok boha prosić: / - Pasi ž, boža, maich koni, / Maich koni ǔ čystym poli, / U čystym poli, u Jurjevych rosach, / U Jurjevych rosach, u Mikoĺskich travach" (A young groom asks God: / God, graze my horses, / My horses in an open field, / In an open field, in George's dews, / In George's dews, in Nicholas's grasses) (Bessonov 1871: 9-10).

The traces of the ancient theriomorphic veneration of divine twins are also worth mentioning. The Vedic Ashvins (Aśvinī, lit. "possessors of horses” or "related to horses") were given birth by Saranyū who took the form of a mare (cf.: the protagonist of "The Horse's Son" folk tale was given birth by a mare). The

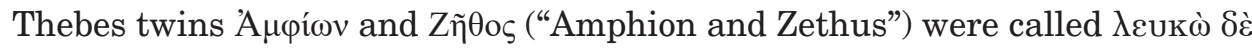

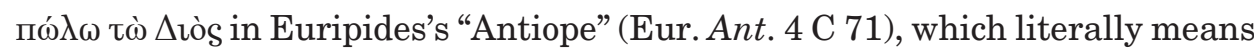
"a pair of Zeus's white stallions". A similar statement can be found in "Heracles":

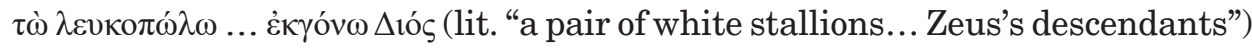
(Eur. Her. 29), even though the epithet $\lambda \varepsilon v \kappa o ́ \pi \omega \lambda \mathrm{("white-horsed")} \mathrm{referred} \mathrm{to}$ another pair of divine twins - Kastor and Polydeuces (Ward 1968: 12; Nikolayev 2012: 123). 
Lyuben Karavelov claimed that Belarusians venerated Saint George in the form of a horse (Karavelov 1861: 215). This claim was also cited in Boris Uspenskiy's work (Uspenskiy 1982: 139). However, it is evidently based on an inaccurate interpretation of a song fragment cited without a character representing the Belarusian sound “ $y$ ” (“ŭ”) (reinstated in square brackets): "Razyhra[ŭ] sia jur[j]ja[ŭ] konik / Zalacieńki konik" (George['s] the horse played much / The golden horse), cf. "Razhuliaŭsia Jurjeŭ koń, / Razbiŭ kamień kapytom" (George's horse played much / Broke a stone with his hoof) (Bartaševič and Salaviej 1979: 173, No. 197). In a fuller variant of this song, the actions of George's horse acquire cosmogonic connotations:

Ǔ čystym poli pad javarom Razhuliaŭsia Jurjï̌ koń.

Razhuliaŭsia Jurjï̌ koń, Chvastom mora raskalychaŭ. Chvastom mora raskalychaŭ, Kapytom kamień razbivaŭ. (Mažejka 1981: 83, No. 36)
In an open field under a maple Yury's horse immersed in play. George's horse immersed in play, Churned the sea with his tail, Broke a stone with his hoof.

In a fairy tale these actions are performed by an anthropomorphic protagonist in order to get the egg containing Koschei's ${ }^{4}$ death:

Jak daŭ liaskaj svajoj pa mory - dabivajecca da taho, što holy kamušak lia jaho. Jak udaryŭ liaskaj pa kamušku, tak kamušak hety razliacieŭsia! Tojčas vutka z kamuška, koršun za jaje da jamu daŭ! Jon uziaŭ hetu vutku, raździor jaje papalam. I jajco heta za pazuchu zaklaŭ. (Bandarčyk 1973: 200)

He hit the sea with his mace and kept hitting until just a stone was left in front of him. As he hit that stone with his mace, the stone broke to pieces. In that instant, a duck flew [out of the stone], but a hawk intercepted it and gave the duck to him. He took the duck and tore it in two halves. And he put this egg under his shirt.

The cosmogonic nature of this type of tales is revealed in another tale's opening:

Heta bylo z pačatku śvieta. Žyŭ Kaščej Biaśśmiertny, i bahatyroŭ usich pabiŭ, i valšebnikaŭ usich pahubiŭ, i ŭkraŭ sonca, $i$ miesiačka, $i$ zorački, i stala ciomna liudziam. (Bandarčyk 1973: 66)

This was at the beginning of time. There lived Koschei the Deathless and he beat all the heroes and killed all the wizards and stole the sun, the moon and the stars, and darkness fell onto people. 
These two motifs (churning of the ocean and breaking the original rock) also appear in a different form in cosmogonic myths of Ancient India. Consequently, George's horse also alludes to cosmogony as it is described as a cosmic animal whose body parts correspond to parts of the Universe:
Jaho konik chvaślivy,
His boastful horse,
Chvastom vulku padmiacie. ...
Will sweep the street with his tail. ...
Vuškami nieba padapre,
Vočkami zory paličyć,
Will prop up the sky with his ears,
Vočkami zory paličyć,
Will count the stars with his eyes,
Will count the stars with his eyes,
Ciabie, maladoha, padvialičyć Will bring glory to you, young man
(Bartaševič \& Salaviej 1979: 173, No. 200)

For comparison, there is a similar but more detailed description of a sacrificial horse in "Bṛhad-āraṇyaka Upanuṣad" (BAU I.1.1) (Radhakrishnan 1968 [1953]: 149).

Two antagonistic characters of Belarusian demonology have hippomorphic features. They were described by Pavel Shpilevskiy (Pavel Drevlyanskiy). One of them is Kumelgan. It is an evil spirit that harms household horses. It was depicted as a creature which had a human body covered with wool, a horse's head, and hoofs on his hands and feet. The second one is called Vazila. He had a humanlike form but with horse ears and hoofs. (Drevlyanskiy 1846: 85-87, 99-101). While existing critique of Shpilevskiy's accounts suggests that they cannot be regarded as a reliable source of Belarusian folklore and mythology (Toporkov 2002: 253-254; Levkiyevskaya 2002: 348-349), no persuasive arguments have been forwarded against the existence of these particular characters. As I have suggested elsewhere (Sańko 2011), these characters may reflect some (partially demonised) features of the "substrate" (Baltic) twins, which later carried over to paired saints George and Nicholas.

It is also important that in both the folk imagination and iconography saints George and Nicholas are depicted as horsemen on white horses (see, for example, Anichkov 1892: 19 on St. Nicholas). With regard to their pairing, a Belarusian charm against snakes is of interest, as Saint George appears there as a double:

... budu prasić śviatoje Jurja i Jahorja. Pryjedzieć śviaty Jury i Jahory na bielym kani, voźmieć try pruty miednych, try pruty zialieznych i pahonić vas na zialiezny tok, i budzieć bić, prabivać i skroź ziemliu prahaniać. (Bartaševič 1992: 136, No. 386)

I will ask Saints Jurja and Jahorja ${ }^{5}$. Saints Jurja and Jahorja will come on a white horse, will take three copper rods and will chase you to the iron barnyard, and will beat, crash, and drive [you] through the ground. 
Many valačobnyja songs emphasise the special relationship between George and Nicholas, on the one hand, and their relation to horses, on the other hand. If one of the members of the pair (either George or Nicholas) is missing, it is only the other one (either Nicholas or George) who can find him, precisely because he owns a horse, unlike other saints:

Da na tych kresličkach da ŭsio praźnički

Rachavalisia, sabiralisia,

Adnaho praźnička nie daždalisia.

Jakoha praźnička? - Śviatoha Mikolu.

Kaho syskać pa Mikolu paslać?

Pietryka syskać pa Mikolu paslać.

Pietryk im adkazyvaje:

- Ja kania nie maju, Mikolu nie znaju.

Nu kaho syskać pa Mikolu paslać?

Illiu syskać pa Mikolu paslać.

Illia ža im adkazyvaje:

- Ja kania nie maju, Mikolu nie znaju.

Aslaviŭsia śviaty Jury:

- Ja konika maju, Mikolu znaju.

Tolki Jury kania siadlaje,

Konika siadlaje, z dvara zjazdžaje,

Z dvara zjazdžaje, Mikolu strakaje

(Bartaševič \& Salaviej 1980: 183, No. 97; variants No. 105, 106, 112, 115, $116,117,119,120$, etc.).

So on these chairs all the holidays

Were gathering and counting each other,

One holiday was missing.

Which one? Saint Nicholas.

Who is to be sent to find Nicholas?

Peter is to be sent to find Nicholas.

Peter replies to them:

- I do not have a horse, I do not know Nicholas.

So who is to be sent to find Nicholas?

Elijah is to be sent to find Nicholas.

Elijah replies to them:

- I do not have a horse, I do not know Nicholas.

Saint George calls:

- I have a horse, I know Nicholas. 
Just as George saddles up a horse,

Saddles up a horse, rides from the backyard,

Rides from the backyard, meets Nicholas.

A similar emphasis on a connection to horses can be found in other paired saints' images, in particular Florus and Laurus, and Boris and Gleb. In Belarusian folklore, this connection manifests differently in the case of George and Nicholas than it does with other paired saints. But the very multiplicity of paired saints who possess a connection to horses points to the influence of an ancient mythological matrix, which persisted for a long time, filling the opening gaps with characters from the newer, folk Christian lore. In this context, it is characteristic that another pair of saints, not hagiographically bound, emerged: that of Chrol (Florus) and Jahorja (George), instead of the canonical pair of SS. Florus and Laurus: "Na Chrala i Jahorja nia tkuć i ni pashuć" (You cannot weave and plow on Florus's and George's [days]) (Dobrovol'skiy 1894: 46).

\section{SS. GEORGE AND NICHOLAS AND TWIN CHARIOTEERS}

It was already Macdonell who noted that despite having very little connection to horse riding in the Vedic tradition, the Ashvins are often described as charioteers whose chariot is more often drawn not by horses but by birds (Macdonell 2002 [1897]: 50). Many hymns in the Rigveda and Atharvaveda depict the Ashvins riding a chariot that carries the daughter of solar deity Surya (Sūryā) or the goddess of dawn Ushas (Ușas).

Particularly interesting are the hymns where the Ashvins act as matchmakers who take Surya's daughter to her bridegroom's home: "Having become pleased, the young girl, the Daughter of the Sun, has now mounted your chariot, o men" (RV 1.118.5ab) (Jamison \& Brereton 2014: 276), "The Aśvins were the wooers of Sūryā and Agni was the leader. // Soma was the bridegroom; the Aśvins were both wooers" (RV X.85.8cd-9ab) (Jamison and Brereton 2014: 1522).

Belarusian valačobnyja songs contain a strikingly similar adaptation of this mythological theme. The only difference is that they focus not on a female deity's marriage but on the birth of God's Son (more on it in Sańko 2016: 42-43):

Za tymi vazami jechala kareta,

Muliavanaja, vyzlačanaja,

To ž a ŭ toj karecie sam Haspoža.

Sam Haspoža, Matka Božža,

Matka Božža i Pračystaja, 
Jana pryjazdžala, sama pavitala, Da na koničku na bulanieńkim, A śviaty Jury za pavoźnička, Śviataja Mikola za pamočnička (Sheyn 1874: 98, No. 147)

A coach drove behind those carts, [It was] painted and gilded, And Our Lady herself was in that coach. Our Lady herself, the Mother of God, The Mother of God, the Most Pure, She arrived, she herself greeted [them], On a brown horse, And Saint George was a coachman, Saint Nicholas was a helper.

Tudym jechala pračystaja, Jana jechala šaśćma kaniami, Šaśćma kaniami ŭsio bulanymi, Karetami maliavanymi, Katočkami ŭsio kovanymi. Śviaty Juryj za pavoźnička, Śviataja Mikola za lahodnička, A śviaty Illia viadzieć kania.

(Bessonov 1871: 4, No. 3; cf. Sheyn 1874: 83, No. 141)

There went the most pure, She rode six horses, Six horses, all of them brown, On painted coaches, On forged wheels. Saint George was a coachman, Saint Nicholas was a friend And Saint Elijah guided the horse.

The Indian and Belarusian examples cited above are also interesting because they refer to a specific aspect of divine twin mythology. 


\section{SS. GEORGE AND NICHOLAS AS PART OF DIVINE (SACRED) TRIADS}

Apart from the abovementioned examples from songs, the association of George and Nicholas with female characters is frequent in charms: "Śviaty Juraj, śviataja Mikola, matka Chrystova" (Saint George, Saint Nicholas, Christ's Mother) (Bartaševič 1992: 312, No. 1051); "Śv. Jury, Śv. Mikola, matka Pakrova" (Saint George, Saint Nicholas, the Mother Pakrova) (Vasilievič \& Salaviej 2009: 265, No. 1230); "Išoŭ śviaty Juraj ź Mikolam, stračaje zarnicu" (There went Saint George with Nicholas, they met Aurora) (Bartaševič 1992: 344, No. 1185).

In comparative studies of Indo-European mythology much research has been conducted on the connection between divine twins and female deities, mostly the Daughter of the Sun (ancient Indian "duhitá süryasya", Lithuanian: "sáulès duktèldukrytè", Latvian "saules meita", "the Sun Virgin") and the morning dawn

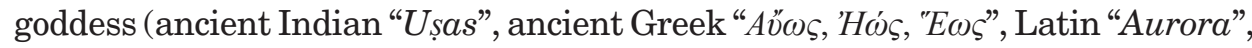
etc.) (Ward 1968: 10-11; West 2007: 227 ff.; Janda 2006: 6). (See Chapouthier 1935 for a detailed analysis of the genesis of this motif and its reflection in the art of classical antiquity.)

Certain parallels found in charms, riddles, and songs indicate that the folk image of the Blessed Mother may have appropriated some features of the preChristian solar goddess: "Zara-zaranica, krasnaja dziavica, pa niebu chadzila, kliučy ŭranila, jak sonca ǔzyjšlo i kliučy najšlo" (Venerable Aurora ${ }^{6}$, a beautiful girl, was walking around the sky, dropped her keys; as the Sun rose, it found the keys) - the answer to the riddle is "dew" (Fiadosik 1972: 46, No. 235, variants No. 227-234), "Ivańkina mamka ŭsiu nočku nie spala, / Usiu nočku nie spala: u Piotry kliučy krala, / Ziemliu razmykala, rasu vypuskala” (John's mother didn't sleep the entire night, / didn't sleep the entire night: she was stealing keys from Peter, / Unlocked the land, let the dew out) (Lis \& Taŭlaj 1985: 213, No. 436, variant No. 682); "Išoŭ sam Haspodź ź niebiasa, zhubiŭ zalatyja kliučy z-pad pajasa. Macier Božaja išla, zalatyja kliučy znajšla" (The Lord himself came from heaven, lost the golden keys from his pocket. God's Mother was walking, found the keys) (Bartaševič 1992: No. 1119), cf. "Miesiac kliučy pahubiŭ, sonca ŭstala, kliučy ŭkrala" (The moon lost the keys, the Sun rose, stole the keys) (Fiadosik 1972: 46, No. 230).

Another persistent association is between SS. George and Nicholas and male Thunderer characters. In the examples above it is exclusively Saint Elijah. The connection with him can also be found in charms texts: "Śviaty Mikola, Śviaty Juraj, Śviaty Illia, / Spasi ad hromu mianie" (Saint Nicholas, Saint George, Saint Elijah, / Save me from thunder) (Vasilievič \& Salaviej 2009: 81, No. 274). Here is another one: "Kacilasia zlata kareta, / U karecie try praźnički: / Pieršy 
praźnik - Jahor chrabior, / Druhi praźnik - Mikola śviatoj, / Jašče praźnik Illia-prarok" (A golden coach was driving, / There were three holidays in the coach: / The first holiday is George the Brave, / The second holiday is Nicholas the Holy, / The last holiday is Elijah the Prophet) (Bartaševič \& Salaviej 1980: No. 12).

However, it is Michael the Archangel who normally possesses the Thunderer's features in charms' texts: “Budu ŭ Boha prasić śviatoha Michajla-archaniela i z hrazoj, i ź pierunom, i z daždžom" (I will ask God for Saint Michael the Archangel with a thunderstorm, and lightning, and the rain) (Bartaševič 1992: 113, No. 307). Saints George and Nicholas go well together with him: “... pryjedzie sam Haspodź sa svaimi apostalami: ź Jurjem, ź Mikolam, ź Michajlam, z Archajlam. Jon vas pierunom pabje, malankaj papalie" (... God himself will come together with his apostles: with George, with Nicholas, with Michael the Archangel. He will strike you with thunder, will burn you with lightning) (Vasilievič \& Salaviej 2009: 140, No. 606); "śviatoha Jahoryja ... śviatoha Mikalaja ... śviatoha Michajla" (Saint George... Saint Nicholas... Saint Michael) (Romanov 1891b: 183, No. 98).

The associations of divine twins with the Thunderer in religions of classical antiquities and non-European nations were meticulously studied by Alexander Krappe (1936). He particularly focused on the triad of Prussian gods at the sanctuary of Romov and outlined several features of twin pairs that are relevant for the present study.

Krappe argued that in a divine pair of twins one is depicted as a young man and the other as an old man; moreover, one is shown as a patron of spring and the other as a patron of autumn and winter (Krappe 1936: 6-8).

\section{SYSTEMATIC DIFFERENCES BETWEEN ST. GEORGE AND ST. NICHOLAS}

Based on his analysis of Renaissance-era texts, Krappe defined the key triad within the traditional comparative framework: Perkuns - Juppiter, Potrimps Castor, Pikuls (Patollo) - Pollux (Krappe 1936: 7), making no distinction between the abovementioned Bardoayts and Potrimps. Vladimir Toporov refined Krappe's juxtaposition by linking the epithet Bardoayts ("bearded") with Patols and, consequently, with the lower world and the sphere of the dead (Ivanov \& Toporov 1983: 170). This idea is also supported by the following text:

[D]as eine war wie ein man junger gestalt ane bardt, gekronett mit sangelen und frolich sich irbot und der gott vom getreide und hies Potrimppo ... Das dritte bilde war ein alter mahn mit einem langen groen bardt und 
seine farbe gantz totlich, war gekronet mit einem weissen tuche wie ein morbant unde sag von unden auff die andern an unde his Patollo mit namen. (Grunau 1876: 77)

One was [the image] of a young-looking man without a beard, crowned with rye ears and with a happy look on his face, the god of grain, called Potrimpo ... The third was the image of an old man with long green beard and an absolutely deathly face colour, crowned with a linen turban-like bandage, who looked down at [two] others and was called Patollo.

It is also very important that there was a heraldic shield under the banner that contained images of the god. It was supported by two white horses standing on their hind legs, and on the shield itself one could see a bear-headed man. Thus in this composition we can see the triad in a theriomorphic code with a twin pair, symbolized by the two white horses.

This is how the Milanese represented their patrons, twin saints Gervasius and Protasius: the first one had a long white beard and the second one was a beardless youngster (Krappe 1936: 8).

If we compare the Prussian pair of saints to their Belarusian counterparts, it is obvious that Potrimpo corresponds to St. George and Patollo corresponds to St. Nicholas. A significant feature of St. Nicholas's iconography is indeed his old age, baldness, and grey beard. A valačobnaja song reads: "A Mikola, stary chaziain, / Pa miežach chodzić, / Žyta raŭnuić" (And Nicholas, the old master, / Walks along the field edges, / Cares for the rye) (Bartaševič \& Salaviej 1980: No. 94). When Nicholas and George had an argument over which one of them a man greeted ("zdrastuj daŭ", lit. "gave a greeting"), Nicholas said: "Mnie daŭ, bo ja čalaviek stary" (He said it to me, because I am an old man) (Hrynblat \& Hurski 1983: 122, No. 139). However, when asked which one of the two is more handsome, the man replied: "Nie, bratcy, abai charašy, usio roŭna jak braty adnaho atca-maciery" (No, brothers, you both are good-looking, as if you were children of the same father and mother) (ibid.: 125, No. 140).

There is one feature that brings Prussian Potrimpo even closer to Belarusian St. George. A highly probable etymology of the name Potrimpo derives from the Lithuanian word "trempti" (to trample). But it is not merely because he walks on the surface of the earth and, thus "trampling" on it, in contrast to the underworld Patollo (Ivanov \& Toporov 1992: 293). We should also take into consideration George's mythical function which was thus reflected in Belarusian folklore: "Dzie Jura stupaje - žyta vyliahaje, / A dzie Jura chodzić - usio zbožža rodzić, / Dzie Jura nahoju - tam žyta kapoju" (Where George steps, rye straightens up, / And where George walks - all grain fructifies, / Where George [puts his] foot - rye is abundant) (Bartaševič \& Salaviej 1980: No. 106). Therefore, we may conclude that "trampler" Potrimpo was stepping on the soil to awaken 
its fertile powers in spring (Ivanov \& Toporov 1983: 170). Moreover, ritualistic stamping that was often accompanied by tapping was an integral part of many dances and circle dances in spring and summer.

Saint Nicholas and Patollo, for their part, share a relation to the underworld (see Uspenskiy 1982: 70-72 on St. Nicholas).

Krappe noted that the different functions of characters within a pair are connected to a particular duplicity of the characters themselves. He supported Grunau's idea that Potrimpo correlates to spring Saturn and Patollo correlates to winter Saturn (Krappe 1936: 8). Ivanov and Toporov drew such parallels as spring and autumn Jarilo (George), spring and autumn Nicholas, Roman rituals dedicated to Mars in spring and autumn (Ivanov \& Toporov 1983: 170-171). This duplicity additionally manifested in the images of old and young Avsen (Toporov 1988) and young and old George.

\section{SS. GEORGE AND NICHOLAS AND THE IDEAS OF TWIN HEALERS}

The belief that divine twins can and will help people in case of disasters and misfortunes, such as shipwrecks, natural disasters, epidemics, and other diseases was very widespread (Bracken 1935; Hankoff 1977; O'Connor \& Hufford 2001). Indo-European cultures especially valued the healing abilities of divine twins (including Dioscuri, Ashvins, Asclepius, Apollo's son (Apollo was a twin himself), Erichthonius's twin brother, the father of twins Machaon and Podalirius who were doctors during the Trojan War) (Hankoff 1977: 308).

There are several texts in Belarusian folklore in which these ideas are reflected in a particular way. Pertinently to the present discussion, some of them mention Saints George and Nicholas as miraculous healers. These are the legends "The doctor", "The cripple and the blacksmith", and "Nicholas and the priest", which were published by Romanov (1891a: 60-79). One other text which comes from the Mogilev Province tells of a poor soldier who shares his dinner three times with two grey-haired old men, each time offering each of them "deniažcy" (money) as alms. Then he meets two gentlemen riding a carriage drawn by a pair of horses. The soldier offers to be their "coachman"; the gentlemen call themselves "doctors" and take it upon themselves to cure the czar's ailing daughter. The way of healing described in these texts is notable: one of the "doctors" who was sitting "s levyje ruki" (on the left-hand side), sharpened the knife, cut all the body parts of the sick girl, put them in a bathtub full of warm water, rinsed them, put them in a bathtub with cold water, then dried all the parts with a rag and re-assembled them in the correct order on the table. 
Then the second "doctor", who was sitting on the right-hand side, blew air three times through the body and revived the princess (Romanov 1891a: 71). In other variants of this tale only one of the characters ("beggar", "Nicholas") treats her this way, while the other one ("blacksmith", "priest") secretly watches him do it. "Nicholas" refers here to paired saint helpers George and Nicholas and the "blacksmith" refers to another popular folk Christian pair: twin blacksmiths Cosmas and Damian who are also famous for being doctors (see also Anichkov 1892: 49). In one of the texts George and Nicholas play the role of two old beggars, even though this variant lacks the healing part. The texts that mention only Nicholas as a doctor may reflect the archaic tradition of naming the entire pair by one of the brothers' names (see above).

The distribution of the functions between the Belarusian "doctors" mirrors that of their more famous counterparts: Asclepius's sons, twin god Apollo's grandsons Machaon and Podalirius. Eitrem regarded these "two brother doctors" together with some other ancient Greek paired characters as a manifestation of divine twins (Eitrem 1902: 92-98). Already Aristides compared doctor brothers Machaon and Podalirius with Dioscuri (Haudry 1992: 357). It is worth men-

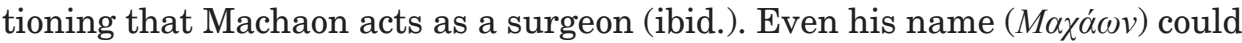
be related to $\mu \alpha \dot{\chi} \alpha \iota \rho \alpha$ "(sacrificial, cooking) knife; blade" (Doederlein 1850: 202; Höfer 1894-1897: 2231), because he used one to cut arrows from the wounds (Hom. Il. XI.844). On the other hand, Podalirius acts rather as a magic healer, using medicine and possibly charms. He is able to "diagnose invisible illnesses and cure incurable ones" (Haudry 1992: 357, 359).

It may be assumed that in the Belarusian legends under consideration, the distribution of functions between Nicholas and George was as follows: Nicholas was a surgeon and George was a thaumaturge (magic healer), but this requires further studies.

The limited scope of the paper does not allow me to analyse some other features of Saint George's and Saint Nicholas's pairing that can be traced to earlier ideas about divine twins. But even the folk ideas about God's helpers George and Nicholas outlined above give us a reason to suggest that they were influenced by an earlier mythological paradigm. This does not mean that the two saints functioned and were perceived as actual twins in folk culture, since folk texts contain no indications they were represented as the sons of the same couple. Compare, however, on the one hand: "Nie, bratcy, abai charašy, usio roŭna jak braty adnaho atca-maciery" (No, brothers, you both are good-looking, as if you were children of the same father and mother) (see above), and the presentation of at least one of the members of the pair, George, as a younger member of a divine family in this valačobnaja song, on the other hand: "Za maim stalom sam boh siadzić. / Piervy kubak - dlia samoha boha, / A druhi kubak - dlia žany jaho, / Treci kubak - dlia Jurja śviatoha" (The God himself 
sits at my table. / The first cup is for the God himself, / The second one is for his wife, / the third cup is for Saint George) (Bartaševič \& Salaviej 1980: 71, No. 27). Here Saint George takes the position that is occupied by the master's children in similar songs: "Zielianoje vino - panu haspadaru, / Čornaje piva - dlia žany jaho, / Saladok miadok - dlia jaho dzietak" (Green vine is for the master, / Black beer is for his wife, / Sweet honey is for his children) (Bartaševič \& Salaviej 1980: 63, No. 18, variants No. 21, 26, 115). These tendencies could not have formed a stable twin complex in the framework of folk Christianity, as many features of divine twins were distributed (and often duplicated) among other popular paired saints, mainly Cosmas and Damian, Peter and Paul, Boris and Gleb, Florus and Laurus, Anthony and Theodosius. Only the complete inventory of all these traits and their comprehensive interpretation will allow us to restore the crucial traits of ancient mythological matrix, including its regional modifications. This study attempts to define such features based on the image of SS. George and Nicholas in Belarusian folklore, which are not represented in the same way in any other parts of Eastern Europe.

\section{ACKNOWLEDGEMENTS}

The article was written as part of a project financed by the Foreign Ministry of Estonia through the Developmental Cooperation Programme (66-2015-A).

\section{NOTES}

1 In the Belarusian folk tradition, the names of saints are pronounced as follows: Saint George - Śviaty Jury (variants Jura, Jurja, Juraj, Jurej, Jahoryj, Jahorja and some others), Saint Nicholas - Śviaty Mikola (variant Mikalaj).

2 The feast of the Intercession of the Theotokos or the Protection of Our Most Holy Lady Theotokos and Ever-Virgin Mary is called Pakrova/Pokrova in Belarus and Ukraine and Pokrov in Russia. These titles are also used as a name of the personified holiday or Mother of God herself.

3 In Belarus the songs that are performed during the Easter Day celebration by groups of singers wandering between villages (valačobniki) are called valačobnyja peśni.

4 Koschei the Deathless in East Slavic folk tales is an archetypal immortal abductor of the hero's wife or bride.

5 As I noted above, both names denote the same character and are not translated here.

${ }^{6}$ In Belarusian texts Zara may designate most likely the Dawn goddess and is to be translated as Aurora. Zaranica is a diminutive form of Zara. This double appeal is to express a special veneration of the goddess. 


\section{REFERENCES}

Anichkov, Evgeniy 1892. Mikola Ugodnik i sv. Nikolai. [Mikola the Saint and St. Nicholas.] Zapiski Neo-Filologicheskogo obshchestva. [Notes of the Neo-Philological Society.] Vol. 2, No. 2, p. 55.

Antonin, arkhimandrit 1873. Yeshchio o svyatitele Nikolaye Mirlikiyskom. [More on Prelate Nicholas of Myra (in Lycia).] Trudy Kiyevskoi dukhovnoi akademii. [Works of the Kiev Theological Academy.] Vol. IV, No. 12, pp. 241-288.

Bandarčyk, Vasiĺ (ed.) 1973. Čaradziejnyja kazki. [Fairy Tales.] Vol. 1. Minsk: Navuka i technika.

Bartaševič, Halina (ed.) 1992. Zamovy. [Charms.] Minsk: Navuka i technika.

Bartaševič, Halina \& Salaviej, Lija (eds.) 1979. Viesnavyja piesni. [Spring Songs.] Minsk: Navuka i technika.

Bartaševič, Halina \& Salaviej, Lija (eds.) 1980. Valačobnyja piesni. [Easter Songs.] Minsk: Navuka i technika.

Bessonov, Piotr 1871. Belorusskiye pesni, s podrobnym obyasneniyem ikh tvorchestva $i$ yazyka, s ocherkami narodnogo obryada, obychaya i vsego byta. [Belarusian Songs with a Detailed Explanation of Their Expression and Language, with Notes on Folk Ritual, Custom and Way of Life.] Moscow: Tipografia Bakhmeteva.

Bracken, Helmut von 1935. Zwillinge als Zauberärzte und Heilgötter. Ciba Zeitschrift, Vol. 23, pp. 780-782.

Bremmer, Jan N. 2008. Greek Religion and Culture, the Bible and the Ancient Near East. Leiden \& Boston: Brill.

Cahier, Charles 1867. Caractéristiques des saints dans l'art populaire. Tome Second. Getc. Paris: Libraire Poussielgue frères. Available at http://gallica.bnf.fr/ark:/12148/ bpt6k5784430n, last accessed on 10 April 2018.

Chapouthier, Fernand 1935. Les Dioscures au service d'une déesse: étude d'iconographie religieuse. Paris: E. de Boccard.

Doble, Gilbert Hunter 1935. Saint Meriadoc: Bishop and Confessor, Patron of Camborne. Truro: Netherton and Worth.

Doble, Gilbert Hunter 1939. Saint Mewan and Saint Austol: Patrons of the Parishes of St. Mewan and St. Austell, Cornwall. Long Compton: King's Stone Press.

Dobrovol'skiy, Vladimir 1894. Smolenskiy etnograficheskiy sbornik. [Ethnographic Anthology of Smolensk.] Vol. III: Poslovitsy. [Proverbs.] St. Petersburg: Tipografia S. N. Khudekova.

Doederlein, Ludwig 1850. Homerisches Glossarium. Bd. I. Erlangen: Ferdinand Enke. Drevlyanskiy, Pavel 1846. Belorusskie narodnye poverya: Statya vtoraya. [Belarusian Folk Beliefs: The Second Paper.] Pribavleniya $k$ Zhurnalu Ministerstva narodnogo prosveshcheniya. [Appendix to the Journal of the Ministry of Folk Education.] Vol. 3, pp. 85-125.

Eitrem, Samson 1902. Die göttlichen Zwillinge bei den Griechen. Christiania: A. W. Brøggers Buchdruckerei. Available at https://bildsuche.digitale-sammlungen. de/index.html?c=viewer\&bandnummer $=$ bsb00067463\&pimage $=4 \& v=100 \&$ nav $=$ $\& \mathrm{l}=\mathrm{de}$, last accessed on 10 April 2018.

Fiadosik, Anatoĺ (ed.) 1972. Zahadki. [Riddles.] Minsk: Navuka i technika.

Fiadosik, Anatoĺ (ed.) 1976. Prykazki i prymaŭki ŭ dzviuch knihach. [Proverbs and Sayings in Two Books.] Book 1. Minsk: Navuka i technika. 
Fomina, Mariya 1984. Zhanrovye i syuzhetnokompozitsionnye osobennosti drevnerusskogo literaturnogo sbornika "Zlatostruj". [Genre and Plot Composition Peculiarities of the Ancient Russian Literary Anthology "Zlatostruj".] Voprosy syuzheta i kompozitsii. [Issues of Plot and Composition.] Gorky: Gor'k. gos. un-t im. N. I. Lobachevskogo, pp. 14-19.

Grunau, Simon 1876. Simon Grunau's preussische Chronik. Bd. I. Leipzig: Verlag von Duncker \& Humblot. Available at http://www.mgh-bibliothek.de/dokumente/a/ a016932+0001.pdf, last accessed on 10 April 2018.

Hankoff, Leon D. 1977. Why the Healing Gods Are Twins. The Yale Journal of Biology and Medicine, Vol. 50, No. 3, pp. 307-319. Available at https://www.ncbi.nlm. nih.gov/pmc/issues/174258/, last accessed on 10 April 2018.

Harris, J. Rendel 1903. The Dioscuri in the Christian Legends. London: C. J. Clay and Sons. Available at https://archive.org/details/cu31924099385084, last accessed on 10 April 2018.

Harris, J. Rendel 1906. The Cult of the Heavenly Twins. Cambridge: The University Press. Available at https://archive.org/details/cultheavenlytwi00harrgoog, last accessed on 10 April 2018.

Harris, J. Rendel 1913. Boanerges. Cambridge: Cambridge University Press. Available at https://archive.org/details/boanerges00harr, last accessed on 10 April 2018.

Haudry, Jean 1992. Podalire et Machaon. Lalies: Actes des sessions de linguistique et de littérature, Vol. 10 (Aussois, 1988 \& 1989), pp. 355-363.

Höfer, Otto 1894-1897. Machaon. In: W. H. Roscher (ed.) Ausführliches Lexikon der griechischen und römischen Mythologie. Leipzig: Druck und Verlag von B. G. Teubner, pp. 2228-2231.

Hrynblat, Majsiej \& Hurski, Anton (eds.) 1983. Liehiendy i padanni. [Legends and Traditions.] Minsk: Navuka i technika.

Ivanov, Vyacheslav \& Toporov, Vladimir 1977. Strukturno-tipologicheskiy podkhod $\mathrm{k}$ semanticheskoy interpretatsii proizvedeniy izobrazitel'nogo iskusstva v diakhronicheskom aspekte. [Structural-Typological Approach to Semantic Interpretation of Fine Art Works in a Diachronic Aspect.] Trudy po znakovym sistemam. [Works on Sign Systems.] Vol. VIII, pp. 103-119.

Ivanov, Vyacheslav \& Toporov, Vladimir 1983. K probleme ltsh: Jumis i baltiyskogo bliznechnogo kul'ta. [On the Issue of Latvian Jumis and Baltic Twin Cult.] Baltoslavyanskiye issledovaniya 1982. [Baltic-Slavic Studies 1982.] Moscow: Nauka, pp. 140-175.

Ivanov, Vyacheslav \& Toporov, Vladimir 1992. Patols. [Patols.] In: S. Tokarev (ed.) Mify narodov mira: Entsiklopediya. T. 2. K-Ya. [Myths of Peoples around the World: Encyclopedia.] Moscow: Sovetskaya Entsiklopediya, p. 293.

Jamison, Stephanie W. \& Brereton, Joel P. (transl.) 2014. The Rigveda: The Earliest Religious Poetry of India. 3 volumes. Oxford \& New York: Oxford University Press.

Janda, Michael 2006. The Religion of the Indo-Europeans. In: K. Jones-Bley \& M. E. Huld \& A. D. Volpe \& M. Robbins Dexter (eds.) Proceedings of the Seventeenth Annual UCLA Indo-European Conference, Los Angeles, October 27-28, 2005. Washington: Institute for the Study of Man, pp. 1-29.

Jankulak, Karen 2013 [2009]. Adjacent Saints' Dedications and Early Celtic History. In: S. Boardman \& J. R. Davies \& E. Williamson (eds.) Saints' Cults in the Celtic World. Woodbridge, UK \& Rochester, N.Y.: The Boydell Press, pp. 91-118. 
Karavelov, Lyuben 1861. Pamyatniki narodnogo byta bolgar. [Records of the Bulgarian Folk Way of Life.] Book 1. Moscow: Tipografiya K. Andersa.

Khlybova, Taisiya 2007. Stikh o Nikole Mokrushe. [Poem about Nikola Mokrush.] Zhivaya starina. [Living Antiquity.] No. 2, pp. 22-26.

Krappe, Alexander H. 1936. Les dieux jumeaux dans la religion germanique. Acta Philologica Scandinavica, No. 6, pp. 1-25.

Leonid, arkhimandrit 1881. Zhitiye i chudesa sv. Nikolaya Mirlikiyskogo i Pokhvala yemu: Issledovaniye dvukh pamyatnikov drevney russkoy pismennosti XI veka. [Vita and Miracles of Nicholas of Myra in Lycia and a Panegyric to Him: A Study of Two Records of Russian Writing of the 11th Century.] St. Petersburg: Tipografiya V. S. Balashova.

Levkiyevskaya, Yelena 2002. Mekhanizmy sozdaniya mifologicheskikh fantomov v "Belorusskikh narodnykh predaniyakh" P. Drevlyanskogo. [The Mechanisms of Mythological Phantom Creation in "Belarusian Folk Traditions" by P. Drevlyanskiy.] In: A. L. Toporkov et al. (comps.) Rukopisi, kotorykh ne bylo: Poddelki $v$ oblasti slavyanskogo fol'klora. [Manuscripts That Never Existed: Counterfeits in the Field of Slavic Folklore.] Moscow: Nauchno-izdatel'skiy tsentr "Ladomir", pp. 311-351.

Lis, Arsienij \& Taŭlaj, Halina (eds.) 1985. Kupaĺskija i piatroŭskija pieśni. [St John's Day and St. Peter's Day Songs.] Minsk: Navuka i technika.

Lopatin, Gennadiy 2006. Kul't sv. Nikolaya po sovremennym belorusskim svidetel'stvam. [St. Nicholas's Cult According to Modern Belarusian Testimonies.] Palaeoslavica, Vol. XIV, pp. 287-313.

Macdonell, Arthur A. 2002 [1897]. Vedic Mythology. Delhi: Motilal Banarsidass Publishers.

Makeyeva, Irina 2009. Chudesa Nikolaya Chudotvortsa o saratsine v russkoy pis'mennosti. [Nikolay the Wonderworker's Miracles of Saracen in Russian Literature.] Trudy otdela drevnerusskoy literatury. [The Works of the Ancient Russian Literature Department.] Vol. 60, pp. 3-28.

Maykov, Leonid 1869. Velikorusskiye zaklinaniya. [Great Russian Incantations.] St. Petersburg: Tipografiya Maykova.

Mažejka, Zinaida 1981. Pieśni bielaruskaha Paazierja. [Songs of Belarusian Poozer'e.] Minsk: Navuka i technika.

Nikolayev, Aleksandr 2012. "Gimn Dioskuram” Alkeya. [Alcaeus' "Hymn to Dioscuri".] Aristey: Vestnik klassicheskoy filologii i antichnoy istorii. [Aristeas: Philologia classica et historia antiqva.] Vol. V, pp. 114-140. Available at https://scholar. harvard.edu/files/nikolaev/files/nikolaev_gimn_dioskuram.pdf, last accessed on 10 April 2018.

O'Connor, Bonnie B. \& Hufford, David J. 2001. Understanding Folk Medicine. In: E. Brady (ed.) Healing Logics: Culture and Medicine in Modern Health Belief Systems. Logan: Utah State University Press, pp. 13-35. DOI: 10.2307/j.ctt46nwrq.5.

Puhvel, Jaan 1969. Hittite annaš šiwaz. Zeitschrift für vergleichende Sprachforschung. Bd. 83, H. 1, pp. 59-63. Available at http://www.jstor.org/ stable/40849411?seq=1\#page_scan_tab_contents, last accessed on 10 April 2018.

Puhvel, Jaan 1977. Devata-Dvandva in Hittite, Greek, and Latin. The American Journal of Philology, Vol. 98, No. 4, pp. 396-405. http://dx.doi.org/10.2307/293802. 
Radhakrishnan, Sarvepalli 1968 [1953]. The Principal Upanișads. London: George Allen \& Unwin Ltd. Available at https://archive.org/stream/ PrincipalUpanishads/129481965-The-Principal-Upanishads-by-SRadhakrishnan\#page/n5/mode/2up, last accessed on 10 April 2018.

Romanov, Yevdokim 1891a. Belorusskiy sbornik. [Belarusian Anthology.] Vol. 4: Skazki kosmogonicheskiye i kul'turnye. [Cosmogonic and Cultural Tales.] Vitebsk: Tipolitografiya G. A. Malkina.

Romanov, Yevdokim 1891b. Belorusskiy sbornik. [Belarusian Anthology.] Vol. 5: Zagovory, apokrify i dukhovnyye stikhi. [Charms, Apocrypha, and Religious Verses.] Vitebsk: Tipo-litografiya G. A. Malkina.

Sańko, Siarhiej 1994. Siužet “pra źniklaha boha”: hiecka-kryŭskija (bielaruskija) paralieli. [The "Missing God" Plot: Hittite-Belarusian Parallels.] Kryŭja: Crivica. Baltica. Indogermanica, No. 1, pp. 5-24.

Sańko, Siarhiej 2011. Kumiaĺhan. [Kumilgan.] In: T. Valodzina \& S. Sańko (eds.) Mifalohija bielarusaŭ: Encyklapiedyčny sloŭnik. [Belarusian Mythology: Encyclopedic Dictionary.] Minsk: Bielaruś, pp. 259-260.

Sańko, Siarhiej 2016. Heniealohija i hermienieŭtyka matyvu "Mifičnaja istota na drevie" ŭ zamoŭnych tekstach: svietapohliadny i kamparatyŭny aspiekty. [Genealogy and Hermeneutics of the Motif of a "Mythic Creature on the Tree" in Incantation Texts: Worldview and Comparative Aspects.] Bielaruski falklor: Materyjaly i dasliedavanni. [Belarusian Folklore: Materials and Research.] Vol. 3, pp. 10-52.

Sheyn, Pavel 1874. Belorusskiye narodnyye pesni, sotnosyashchimisya $k$ nim obryadami, obychayami i suyeveriyami, s prilozheniyem obyasnitel'nogo slovarya i grammaticheskikh primechaniy. [Belarusian Folk Songs with Relevant Rituals, Customs, and Superstitions, Supplemented by an Explanatory Glossary and Grammar Notes.] St. Petersburg: Tipografiya Maykova.

Sheyn, Pavel 1893. Materialy dlya izucheniya byta i yazyka russkogo naseleniya SeveroZapadnogo kraya. [Materials for the Study of Ways of Life and Language of the Russian Population of the North-Western Region.] Vol. II: Skazki, anekdoty, legendy, predaniya... [Tales, Jokes, Legends, Traditions...] St. Petersburg: Tipografiya Imperatorskoy akademii nauk.

Sreznevskiy, Izmail 1867. Svedeniya $i$ zametki o maloizvestnykh $i$ neizvestnykh pamyatnikakh. [Information and Notes about Little-Known and Unknown Records.] I-XL. St. Petersburg: Tipografiya Imperatorskoy akademii nauk.

Tolstaya, Svetlana 2001. Antroponimy v narodnoi kalendarnoi terminologii: (Na primere polesskogo narodnogo kalendarya). [Anthroponyms in Folk Calendar Terminology (on the data from Polesian folk calendar).] Izvestiya Ural'skogo gosudarstvennogo universiteta. [Reports of the Ural State University.] No. 20, pp. 54-59.

Tolstaya, Svetlana 2005. Polesskii narodnyi kalendar'. [Polesian Folk Calendar.] Moscow: Indrik.

Toporkov, Andrey 2002. O "Belorusskikh narodnykh predaniyakh" i ikh avtore. [On "Belarusian Folk Traditions" and Their Author.] In: A. L. Toporkov et al. (comp.) Rukopisi, kotorykh ne bylo: Poddelki v oblasti slavyanskogo fol'klora. [Manuscripts That Never Existed: Counterfeits in Slavic Folklore Field.] Moscow: Nauchnoizdatel'skiy tsentr "Ladomir", pp. 245-254.

Toporov, Vladimir 1988. Avsen' i “Avsenevy” teksty v svete rekonstruktsii. [Avsen and "Avsen's" Texts in Light of Reconstruction.] Etnolingvistika teksta: Semiotika 
malykh form fol'klora. [Ethnolinguistics of Text: The Semiotics of Small Folklore Forms.] T. I: Tezisy i predvaritel'nye materialy $k$ simpoziumu. [Abstracts and Preliminary Materials of the Symposium.] Moscow, pp. 16-21.

Toporov, Vladimir 1989. Ideya svyatosti v Drevnei Rusi: vol'naya zhertva kak podrazhaniye Khristu - Skazaniye o Borise i Glebe. [The Idea of Holiness in Ancient Rus': Free Sacrifice as the Imitation of Christ: The Legend about Boris and Gleb.] Russian Literature, Vol. XXV (1), pp. 1-102.

Turilov, Anatoliy 1996. Vizantiyskii i slavyanskii plasty v "Skazanii inoka Khristodula" ( $\mathrm{k}$ voprosu o proiskhozhdenii pamyatnika). [Byzantine and Slavic Layers in "The Story of Enoch Khristodul" (on the Issue of the Work's Origin).] In: G. Litavrin (ed.) Slavyane i ikh sosedi. [The Slavs and Their Neighbours.] Issue 6. Grecheskii $i$ slavyanskii mir $v$ sredniye veka $i$ ranneye novoye vremya: $S b$. statei $k$ 70-letiyu akademika G. G. Litavrina. [Greek and Slavic World in the Middle Ages and Early Modern Time: The Collection of Papers in Honour of Academician G. G. Litavrin's 70th Birthday.] Moscow: Indrik, pp. 81-99.

Uspenskiy, Boris 1982. Filologicheskiye razyskaniya v oblasti slavyanskikh drevnostei (Relikty yazychestva $v$ vostochnoslavyanskom kul'te Nikolaya Mirlikiyskogo). [Philological Research in the Field of Slavic Antiques (The Remnants of Paganism in the East Slavic Cult of Nicholas of Mura in Lycia)]. Moscow: Izd-vo Moskovskogo un-ta. Vasilievič, Uladzimir \& Salaviej, Lija (eds.) 2009. Zamovy. [Charms.] Minsk: Bielaruś. Vinogradov, Nikolay 1907. Zagovory, oberegi, spasitel'nye molitvy i proch. [Charms, Amulets, Salvatory Prayers, etc.]. Vol. I. St. Petersburg: Tipografiya I. N. Kushnereva i Ko.

Vinogradov, Nikolay 1908. Zagovory, oberegi, spasitel'nye molitvy i proch. [Charms, Amulets, Salvatory Prayers, etc.]. Vol. II. St. Petersburg: Tipografiya I. N. Kushnereva i Ko.

Vinogradov, Nikolay 1910. Zagovory, oberegi, spasitel'nye molitvy i proch. [Charms, Amulets, Salvatory Prayers, etc.] Vol. III. St. Petersburg: Tipografiya I. N. Kushnereva i Ko.

Wackernagel, Jacob 1905 [1896]. Altindische Grammatik. Bd. II, 1. Einleitung zur Wortlehre: Nominalkomposition. Göttingen: Vandenhoeck \& Ruprecht.

Ward, Donald 1968. The Divine Twins: An Indo-European Myth in Germanic Tradition. Berkeley \& Los Angeles: University of California Press.

West, Martin L. 2007. Indo-European Poetry and Myth. Oxford: Oxford University Press. Zaykovskiy, Vitaliy 1994. Narodnyi kalendar' vostochnykh slavyan: Vospriyatie vremeni cherez personifitsirovannye prazdniki, obyedinennye v pary. [East Slavic Folk Calendar: The Perception of Time through Paired Personified Holidays.] Etnograficheskoye obozreniye, No. 4, pp. 53-65.

Zholobov, Oleg 1997. Drevnerusskoye dvoystvennoye chislo v obshcheslavyanskom kontekste. [Ancient Russian Dual Number in General Slavic Context.] Kazan: Unipress.

Zholobov, Oleg 1998. Simvolika i istoricheskaya dinamika slavyanskogo dvoystvennogo chisla. [Symbolism and Historical Dynamics of the Slavic Dual Number.] Frankfurt am Main \& Berlin \& Bern \& New York \& Paris \& Wien: Peter Lang.

Zholobov, Oleg \& Krys'ko, Vadim 2001. Istoricheskaya grammatika drevnerusskogo yazyka. [Historical Grammar of the Ancient Russian Language.] T. II: Dvoystvennoye chislo. [Dual Number.] Moscow: Azbukovnik. 


\title{
ON THE BORDERS OF ETHNOLINGUISTIC EQUIVALENCE: BELARUSIAN-SOUTH SLAVIC PARALLELS
}

\author{
Nikolai Antropov \\ Center for Belarusian Culture, Language and Literature Research \\ National Academy of Sciences, Belarus \\ e-mail: antropov50@gmail.com
}

\begin{abstract}
This article compares and analyses, with the involvement of recent Belarusian materials, the two fragments of Belarusian spiritual culture and relevant South Slavic traditions, related to: a) Christmas (in southern Slawiya, it is concentrated around the badnjak, a log burned on Christmas Eve), and b) bear days/festivities (called kamajedzica in Belarusian ethnoculture). It is acknowledged that the detection of new pairs of Belarusian-South Slavic isolexes/ isodoxes/isopragms or the new interpretation of those detected earlier is not only valuable as a fact, but also as a chance for providing heuristic evaluation of the outcome of such comparison for the purposes of a new comprehension of the nature of different phenomena of spiritual culture under comparison, within their own rite-ritual continua and, in relation to that, for objectifying the historical borders of ethnolinguistic equivalence.
\end{abstract}

Keywords: badnjak, bear days/festivities, Christmas, equivalence, ethnolinguistics, kamajedzica

The particular value of Belarusian-South Slavic ethnolinguistic equivalents (convergences) has been repeatedly pointed out and discussed in scientific literature (Antropov, Cychun, Kryvicki, Radenković, Tolstoi, and others). However, continuing the search in that regard is still relevant, and not only because finding new pairs of isolexes/isodoxes/isopragms or a new interpretation of those already substantiated would be indicative of the existence of ancient bonds between certain language formations in the south and the east of the Slavic world (Cychun 1983: 4), but also because of the possibility to heuristically evaluate the efficiency of such comparison for the purposes of new apprehension of the nature of the phenomena of spiritual culture under comparison, both in their own rites and ritual spheres and in the overall Slavic context in general. The latter lemma seems to be of crucial importance in terms of defining the borders 
of ethnolinguistic equivalence, i.e., posing the question that could be articulated as follows: do the phenomena of the traditional culture of the two Slavic (ethno) linguistic/-cultural continua under comparison have a typological character (with due consideration of deep Indo-European or all-European common roots), or can we assume a multidirectional - both temporal and spatial - genesis of ethnocultural dialectic phenomena of (late)proto-Slavic era?

\section{ETHNOCULTURAL CHRISTMAS COMPLEXES}

In the sense asserted above, it seems not incurious to once again opt for systemic consideration of a number of elements of actional, but especially objectspecific code of such rite complexes that are rich in multi-faceted semantics as Christmas rites and rituals, both in South Slavic and Belarusian traditions. The research earlier conducted by the author on the basis of other material of traditional spiritual culture (Antropov 2004: 75-84; Antropov 2007b: 10-18) has shown that it is the object-specific code that is diagnostic in terms of steady delimitation of homogeneous elements in each one of them. In the South Slavic Christmas traditions, different actions with the Christmas log, the badnjak, seem to be of extreme importance, as is everything related to and happening around it. A general overview of the badnjak as 1) the name of the log that is burnt on Christmas Eve, and 2) the name of the main ritual of the Christmas cycle of the South Slavs has been presented in a number of published works (Kulišić 1970: 20-22; Tolstoi 1995: 127-131) and some local variations and the Common-Slavic perspective of the ritual (in Tolstoi 1986: 128-131). The summarized "benchmark of the ritual", which, in the opinion of Nikita Tolstoi, mainly reflects a Serbian-Bulgarian variation, contains the following set and sequence of ritual activities: felling the badnjak, taking it to the house, putting it up in the yard near the house, bringing it into the house, meeting and greeting the badnjak, laying it on the fire, kissing the badnjak, feeding it, beating the fireplace (this is done by the polaznik, the first person who visits the family on Christmas Day), guarding the badnjak, burning it into two halves, and keeping the soot and ashes for further use in many different ways (cf. Toporov 1976: 9-11 for common features of the ritual).

In the opinion of Tolstoi, some specific motives of South Slavic ritual actions with the badnjak have something in common with the Ukrainian ritual kolodka (chump) ${ }^{1}$ and the Belarusian ritual of bringing firewood into the house for Christmas: ${ }^{2}$ 
V den'Roždestva Christova každyj hozjain, vstavši iz-za stola posle obeda, dolžen vnesti $v$ hatu tri polena drov, kotorye kladutsja na $g r j a d k u$ (matica, poperečnaja perekladina $v$ izbe) $i$ hranjatsja do teh por, poka ne pospeet rož'.

On the day of the birth of Christ, every master of the house, after finishing his lunch, must bring three logs into the house, which should be put on the beam and kept there until the rye has ripened.

It follows from the text that later on these logs are used to heat the barn when the sheaves are about to be dried, with a rare personified, even naive and poetic motivation - so that the barn is protected from fire throughout the whole year. Thus, in addition to the common element of "bringing it into the house", for the Belarusian tradition it is also possible to reconstruct the hidden motif of a wholesome Christmas fire related to Christmas $\operatorname{logs}^{3}$ (cf. a similar appeal in relation to the badnjak). The motif of "bringing the logs into the house" can clearly refer to a similar widespread action that precedes girls' Christmas "oddeven" fortune-telling (e.g. Seržputoŭski 1998 [1930]: 138):

Na peršuju Kuccju. Posle večjery dzeŭki bjaguc' na dryvotnik i bjaruc’ tam ne ličačy vjaliznae bjarjemja droŭ i njasuc' ich u chatu.

At first Kuccia. After supper, the girls run to the woodshed and pick, without counting, a large bunch of firewood and carry them into the house.

The commonality of the object-specific code of the ritual adjoins the abovementioned tradition: the burning of the badnjak / Christmas logs by the master of the house, which in the Belarusian tradition has been recorded in the south of the Sluck (Slutsk) locality of the Minsk Region (Seržputoŭski 1998 [1930]: 141) and in western Polesye (Tolstaya 2005: 84):

a) Na Kaljady zapal'vajuc' agon' $i$ zapal'vac' pavinen mužčyna, a ne žančyna, kab perasceragscisa at pažaru;

At Christmas, a fire is lit and a man should do it, not a woman, to protect himself from the fire;

b) Mužčyny ž rospaljuvaly drova v pyči pjeršogo dnja na Novyj god, na Koljady drugogo dnja i potom na Vodochrišča - try razy.

Men also kindle firewood in the stove on the first day of the New Year, on the second day of Christmas and then on Epiphany - three times.

Without doubt, the "fire-preventive" expansion of the cultural semantics in the Sluck evidence is clearly secondary.

It resembles "feeding the badnjak", which has been mentioned in Tolstaya (1986: 106), i.e., the custom of pouring the remains of the funeral repast (kolivo 
'coliphia'4, perhaps) on the firewood. See a description from eastern Polesye in the same source (ibid.):

Na dedy jak pominajut, iz pominalnogo bljuda $\breve{u}$ bljudečko nemnogo zlivali. A s togo bljudečka na drugij den' vylivajut na drova, šob zgoralo, a dym do boga šoŭ.

When the dead are remembered on Dedy [one of the memorial days of the year], a little is poured into a saucer from a memorial dish. And from that saucer on the second day they pour on wood so that it would burn, and smoke would go to God.

It is clear that time constituents of the actions compared are different (Christmas - Dziady (commemoration of the dead)), but if we take into consideration the existence of the commemorative segment in the overall semantics of Christmas (and Christmastide in general), which has been emphasized repeatedly, the relatedness of these ritual elements will not seem far-fetched.

An interesting parallel to "beating the badnjak/fireplace" by a polaznik (striking the sparks out), which was wishing hosts well, more precisely, the possibility of semantic relatedness of the definitions badnjak/polaznik $\leftrightarrow$ char/ guest, is demonstrated by the following beliefs documented in the Sluck Polesye (Seržputoŭski 1998 [1930]: 160):

a) Kali ŭ pečy drovy raskocjacca tak, što až galaveška ŭpadze da dolu, to z'javicca daljoki gosc';

If in the stove the firewood rolls apart, so that a piece of charcoal even falls down, a distant guest will appear;

b) Kali drovy raskocjacca ŭ pečy tak, što palena abo galaveška vykacicca až na prypek, to hutka prykocjacca gosci.

If the wood rolls apart in the oven, so that a log or a piece of charcoal even rolls out onto the hearth, the guests will quickly roll over.

In the other short text, what is peculiar is a series of verbs with the root $\kappa a u_{-}$ $i u_{-} / \kappa o ́ u_{-}-я u_{-}$- and the prefixes of space semantics, the last of which manifests

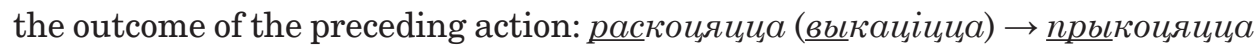
(semantically and derivationally intensified by the preceding $\underline{n p b \iota n e \kappa) . ~}$

However, the most amazing coincidences are marked in the semantics of ritual actions that are related to keeping and reusing badnjak / Christmas soot and ashes, on which, as it is known, the properties of the things that have been burned are projected (Plotnikova 2004a: 666), which, on top of everything else, is once again indicative of the specific status of Christmas firewood in the Belarusian tradition. It is essential that the most important determinative, both in the Belarusian tradition and in South Slavic cultures, is the black colour of 
soot. Thus in Edessa (southern Macedonia) the badnjak char was buried in the vineyard, so that "the grapes would be black", i.e., ripe and juicy; in western Macedonia (Debar) it is kept for treating domestic animals (Tolstoi 1995: 130). Mediated correlations to it can be seen in the opposition of "black soot - black lamb (sheep)", which is present in a number of superstitions written down in the Viciebsk Region: Christmas soot must not be put out because otherwise black sheep will be born; if you rake the fire out from the stove at Christmas and throw it away, black lambs will be born; if you want black sheep to multiply, you should pour Epiphany water over soot and then take it out to the sheepfold (Vasilevich 1998: 354, 362, 379; adapted from Aleksandr Pschelko and Nikolay Nikiforovsky). In the same ethnocultural region, derivatives have also been recorded (that are clearly dependent on basic concepts): lambs will be born black if you dirty your shoes with soot at Christmas; for the sheep not to be bandy-legged, the mistress of the house should leave ashes and soot in the stove at Christmas (Vasilevich 1998: 356, 363; adapted from Nikolay Nikiforovsky and Yevdokim Romanov). The latter belief, which, most probably, could be transformed reconstructively into the Christmas ban on taking soot and ashes out of the house, which also exists in the Bulgarian and Polesye Ukrainian traditions (Plotnikova 2004a: 669-670), is related to the overall semantics of Christmas (Christmastide) evenings being "holy" ones, during which it was undesirable to perform certain actions because of the danger for future crops or domestic animals.

Quite representative is also the ritual use of ashes left after burning the badnjak and firewood at Christmas in the South Slavic and Belarusian traditions (see Tolstoi 1995: 130-131; Plotnikova 2004a: 667-668; Tolstaya 2005: 267; PA; Varlyha 1972: 8; Vasilevich 1998: 334, 371):

1) scattering it in the fields, gardens, and vineyards by the southern Slavs (north-western Serbia (Jadar), Macedonia, Bulgaria (Pirin Region), Viciebsk Region; also observed in Ukraine in Chernihiv (Chernigov) and Zhytomyr oblasts);

2) dusting the roots of planted fruit trees with ashes (in the Bulgarian tradition, wine mixed with ashes and crushed nuts is poured over the roots), so that they bear plenty of fruit (north-western Bulgaria, the area of Kyustendil, Minsk Region (the south of the Sluck District), the central part of western Polesye);

3) sowing grain mixed with ashes (eastern Macedonia, eastern and southern Thrace in Bulgaria, Viciebsk Region $)^{5}$;

4) dusting vegetables and sprouts with ashes against pests (Herzegovina, western Bosnia, Hrodna (Grodno) Region); 
5) rubbing it into the bodies of domestic animals for prophylactic purposes and rubbing it into lichen as an element of remedial magic (Thrace and the area of Plovdiv in Bulgaria, Minsk Region, Homiel (Gomel) Region).

The sacral status of the first Christmas ashes (unique to the Belarusian tradition) is vividly emphasized by its use in Christmas / New Year fortune-telling which predicted the coming back from war (= 'life - death'), recorded in the Viciebsk Region (Volodina):

Byli ne pryšli z armii mužyki, i vos' jany [ženščiny] gadali, ci jos'jany dze žyvyja. Na bljudačak naseili popilu, kab popil byŭ čys'cin'ki, k a l a d n y, vot [kotoryj polučilsja] na pervuju kaljadu, a patom na ftaruju kaljadu možna gadac'. Pos'le nakryvajuc' popil belen'kaj bumažačkaj... patom staviš stakan ... čys'cin'ki, bez rubcoŭ... Vady nalivaiš $i$ kalco [obručalnoje] kidaiš ŭ stakan ... kab jano bylo ... pasradzi stakana... Nu i zerkala, balšoja zerkala. I sadzis'sja, naginais'sja i gljadziš u kalco ŭ zerkali, i vidziš. I vot pagljadzela byla mačacha, $i$ sasedka, $i$ ŭvidzili jany. Adna ŭvidzila bugor zjamli, bugor taki nasypany i palka, i drugaja [to že uvidela].

[After the war] men did not come from the army, and they [the women] wondered if they were alive. The ashes were sprinkled on a saucer, but such that the ashes were clean, from Christmas, [which were left after burning of firewood] on the first day of Christmas, and then on the second day of Christmas you can tell fortune. Then they cover the ashes with white paper... then you put a glass ... clean, without scars [facets]... You pour water and put the ring [engagement] in the glass ..., so that it appears ... in the middle of the glass... And the mirror [you put], a large mirror. And you sit down, lean over, and look at the ring in the mirror, and you see... And then my stepmother and neighbour looked and they saw it. One saw a hillock of soil, a hillock that was piled up, and a stick, and the second [saw the same things].

In view of the above-mentioned practices, both the issues concerning the obvious ethnocultural Belarusian-South Slavic equivalents in the field of Christmas ritualism, which, without any doubt, are difficult to be reduced to their typological essence, and the potential linguistic and, hence, ethnolinguistic indices of this equivalence have acquired a new dimension. This is all the more essential, as the existence of the terminological row in the ritual and rite field, in particular, the names of the rite on the whole, its important parts, etc., facilitate its conservation to a large extent and - when one or another rite-ritual ceases to be practiced - also the memories thereof (which will be displayed later through another example). As for the badnjak, such an attempt was made by 
Vladimir Toporov, who believed that when "taking into account the importance of ashes in this rite..., we must consider the possibility of including in a specified range of words of the Russian and Belarusian budnik, budnyi (compare budnoje delo) 'zolnik, -yi', 'potashnik, -yi'" (Toporov 1976: 10). However, to the best of our knowledge, this remark has never evolved into anything bigger, perhaps because the Russian and Belarusian names are derivatives of the borrowing from the Polish language (in Belarusian literary texts since 1527, in Ukrainian texts since 1530, in Russian texts since 1634): buda "forestry enterprise for wood processing; tar distillatory", "tar distillation, potassic, or saltpetrous enterprise in the forest and a settlement near it", "forest products" (e.g., chotyri budy popelu dobrogo) (ESBM 1978: 398-399; ESUM 1982: 277; GSBM 1982: 231; Shelud'ko 1931: 23; SRJ 1975: 344, 346).

Consequently, it should be acknowledged that on the Belarusian (and East Slavic on the whole) linguistic territory, there are simply no special cultural terms that could be correlated with proto-Slavic dialectal ones (South Slavic *bzdbnz (SP 1974: 459) or *bsdbńbjb (ERSJ 2003: 69). However, it is perfectly clear because even the South Slavic badnjak, as was aptly noted by Nikita Tolstoi, "is neither typologically nor genetically a single whole. It contains different aspects, some of which could be qualified as Slavic and Baltic-Slavic (opening up to the Indo-European perspective) and others as Balkan ones (opening up to the same perspective), and the third group can be qualified as the outcome of various impacts and effects in wide areas of ethnocultural tradition" (Tolstoi 1986: 131; see more information about the latter in Kulišić 1970: 22).

The material presented in this text allows us to make an assumption concerning the fact that the existence of a consistent row of correlative elements of actional, object-specific, subject-specific, and other codes in Belarusian and South Slavic Christmas traditions is, in terms of the Belarusian traditional culture, not so much a typological, but rather a genetic factor, determined by the peculiarities of the ethnogenesis of the Belarusians. The names and the aspects of cultural terminology as such are represented here by the opposition of existence/absence, but with the availability of nominative rows, with their own lexical database in each of the traditions (Antropov 2007a: 71), which could be one of the themes of ethnolinguistic equivalence of this kind.

\section{BEAR DAYS/FESTIVITIES}

Another type of ethnolinguistic equivalence is revealed in the extremely archaic South Slavic bear days/festivities and relevant local Belarusian traditions in two ethnocultural areas that are geographically opposite. Notably, in this case, 
there is a reverse situation in the terminological field, namely, the availability of the name of the rite and, at the same time, of the ritual term in the Belarusian tradition, with the absence of such in the South Slavic and the neighbouring Albanian traditions. It should be emphasized that it is only in the Belarusian, on one side, and in the Macedonian, Serbian and, partly, Albanian (Plotnikova 2004b: 292-293) ethnocultures, on the other side, that these rituals have been preserved in quite an integral whole, as compared to individual representations and actions in other Slavic traditions, which are fragments of the European or even the Eurasian cultural heritage of the extremely distant past (see Ivanov \& Toporov 1994: 128-130; Gura 1997: 211-215 for additional information). This refers to the Belarusian kamajedzica and the New Year customs of the ritual feeding of a bear (a she-bear) observed in Macedonia (in the neighbourhood of Skopje, Tetovo), Serbia (in Kosovo, the Resava region), and southern Albania among the Orthodox inhabitants of the Deval River (Schneeweis 1925: 83; 1961: 109; Plotnikova 2004b: 292).

The Macedonians and the Serbians from Kosovo cook a thick parturient porridge for a she-bear who will supposedly give birth on New Year's Eve (St. Vasily's (Basil's) Day) (Serb. коте се мечка), мечкина повојница оr бареница, mainly from corn flour: "Свака кућа прави колобоћне баренице за повојницу" (In each house a special barenica is cooked as a gift [for the bear]) (Debelković 1907: 251), which is sometimes mixed with milk but is still quite thick (Elezović 1932: 32; 1935: 13). It is revealing that just about all of the Serbian names for bread/flatbread (of the meals of the mămăligă ${ }^{6}$ type) with the roots баран-, боран-, барен- are the names of ceremonial dishes and are directly or indirectly related to the naming of domestic animals (see ERSJ 2003: 187). The Serbs of the Resava River baked a special kind of bread called мечки повојница (a gift to a new-born bear). Compare with the similar barenicu kačamak or nešto za ručak (gift to a bear) in Kosovo, which was brought out of the house by the mistresses of the house who were addressing the bear: "Evo ti nosimo povojnica, posle da ni ne diraš stoka" (This is our gift that we bring you, so that you do not tear [ruin] our cattle) (Vukanović 1986: 373). The Orthodox inhabitants of southern Albania baked a special round loaf (a pie or flatbread) called arushkë (a she-bear). ${ }^{7}$ It is important to stress that before eating the arushkë, it was taken out of the house for several minutes (Ivanova 1973: 299-307). It was the idea of Anna Plotnikova that in the general semantics of the rite, both the actions aimed at mollifying the bear and protective, apotropaic acts are combined, and are related to a symbolic "putting out" of the bear's eyes (which is imitatively done by pinning of the upper bread crust or piercing the bumps on it), so that in summer the bear would not destroy corn plantings or attack cattle (Plotnikova 2004b: 292-293). 
As for the Belarusian kamajedzica, until recently, it was seen as something ethnoculturally unique, since researchers could only use a single record of the rite, which was described and published in the last quarter of the nineteenth century by the local priest Simeon Nečajev in the then existing Biahomí Parish of the Barysaŭ District of the Minsk Governorate (Nečajev 1874: 229-230). This description was noticed by a famous collector and publisher of Belarusian folklore, Pavel Shein, and was included in the third volume of his renowned collection (Shein 1902: 162-163), after which it was repeatedly published in many different publications. Comparatively recently, the author of this article discovered a similar, anonymous text with a number of important additions, which was published in 1879 in an eparchial yearbook. Judging by some common aspects of both publications, this text had been written by Nečajev. It is republished for the first time below (it has Latin characters based on the contemporary Cyrillic alphabet; the author's spelling has been more or less preserved, while punctuation marks have been preserved completely; angle brackets contain the reconstruction of the fragments of the text which were clearly typographical mishaps in the original text):

Kamojedica prazdnuetsja v čest' medvedja, i ustanovlena dlja togo, čtoby on ne sjel kogo-libo, kogda budut' hodit' letom v les za lykami, jagodami, gribami i orechami. Počemu v označennyj den' oni ničego ne delajut, dlja togo, čtoby i medved' ničego ne sdelal chudogo. Ženščiny, obyknovenno $v$ etot den' odna druguju straščajut tak: 'oj ne prad<i> segodnja, kuma, bo medved'zadjarec', jak pojdeš u <les pa> gribe'-Meždu tem prigotovljajetsja obed, sostojaščij iz sledujuščich kushan'jev: varenoj botvy ot repy, ili brjukvy, zasušennych letom, - takoe bljudo prigotovljajetsja dlja togo, čtoby napomnit', čto i medved' možet pitatsja rastitelnoju piščeju, - i vtoroe bljudo kamy, ot kotorogo i prazdnik poluča<e>t nazvanije kamajedicy. Kamy sii delajutsja iz parennogo gorocha, $i$ vsja sem'ja naedajetsja sim bljudom nepremenno dosyta. Posle obeda vse ložatsja spat', no sobstvenno ne spjat, a pominutno povoračivajas's boka na bok, revut $i$ mychat pomedvežjemu, čtoby napomnit' etim rev i mychanie medvedja, ležaščego $v$ berloge. Nakonec, vse vstajut i raschodjatsja; znachit i medved' vstal iz svoej berlogi i pošel po lesu. Po mneniju krest'jan, medved' na Blagoveščenie probuždajetsja ot spjački, vot potomu $i$ svoju kamoedicu oni prazdnujut pred etim dnem, čtoby črez to vstretit' medvedja s blagopoželanijami. Prazdnik etot osobenno sobljudajetsja krest'janami derevni Volči, kotoraja okružena byla dremučimi i neprochodimymi lesami, v kotorych vodilos' množestvo medvedej, pričinjavšich mnogo vreda, istrebljaja celyje polja, osobenno gorocha, a takže často ubivavšich skot i ljudej, a inogda jakoby vyryvavšich i pokojnikov iz mogil. Vot, čtoby umilostivit’ sego zverja, ljudi $i$ 
pridumali v čest' ego prazdnik, kotoryj, bez vsjakogo somnenija, vedet svoje načalo ot vremen jazyčestva, $i$ daže imejetsja predanije, čto $v$ starinu v etoj mestnosti ljudi bogotvorili medvedja. Nekotorye kamojedicu spravljajut $v$ sredu na četvertoj nedele velikogo posta.

Kamojedzica is celebrated in honour of the bear, and is set so that it does not eat anyone when they go to the forest in the summer for splint [fibrous part under the bark of deciduous trees], berries, mushrooms and nuts. Therefore, on this day they do nothing, so that the bear does nothing wrong. On this day, women usually frighten each other in the following way: 'Oh, do not strand today, kuma, because the bear will kill you when you go to the forest for mushrooms.' - Meanwhile, a dinner is cooked, consisting of the following dishes: boiled leaves from turnips, or swede dried in summer - such a dish is cooked in order to remind that the bear can also eat vegetarian food - and the second dish is kamy, from which the feast received its name kamajedzicy. This kamy is made from steamed peas, and the whole family eats this dish to the full. After lunch, everyone goes to bed, but they do not actually sleep, but are constantly turning from side to side, roaring and mumbling like a bear, to remind the roar and mooing of a bear lying in a lair. Finally, everyone gets up and leaves; then the bear also rose from his lair and walked through the forest. According to the peasants, on the Annunciation the bear is awakened from hibernation, that is why they celebrate their kamojedzica before this day, in order to meet the bear with good wishes. This holiday is especially observed by the peasants of the village of Volčy, which was surrounded by dense and impenetrable forests, in which there were many bears that caused much harm, destroying whole fields, especially peas, and also often killed livestock and people, and sometimes allegedly tore dead people from the graves. Here, in order to propitiate this beast, people invented a feast in its honour, which, without any doubt, originates from the time of paganism, and there is even a tradition that in olden times people worshiped a bear in this locality. Some people mark kamojedzica on Wednesday in the fourth week of the Great Lent.

As is seen from this verbose text, relevant elements in bear-related rituals within the traditions that are being compared overlap in the most prominent features, namely in the culinary code (cornmeal porridge - pea balls), the motifs of making nice and greeting the animal, which can serve as evidence of their originally totemic nature (see a direct reference in the text: "in the olden times, people were worshipping bears here"; see also Licjvinka 2001: 61). This text is also very important because it virtually eliminates the issue concerning 
the authenticity of the record of kamajedzicy. (Admittedly, the South Slavic material has propagated this authenticity even earlier.) However, some of the issues might still be under consideration, and, firstly, it concerns the name, since the composite word колоедица (kamajedzicy) with an absolutely transparent structure (eating komy from boiled peas) cannot but seem artificial to some extent, but more precisely as an outcome of folk etymology and/or terminological creation by the people having participated in the rite. However, an attempt to link the Belarusian naming to the name of the ancient Greek bear festival Comoedia in honour of the goddess Artemis, which was supposedly celebrated around the 25th of March (Zajkoŭski \& Sanjko 2004: 334), should be regarded as ill-founded. No matter how original it might seem, it has never been supported with any kind of historical or ethnocultural evidence: fundamental sources related to the ancient Greek language and culture do not confirm the existence of such a festival.

In recent years, Belarusian folklorists have filed some new records directly concerning the rite or related to it, which expressly contain the naming, for example:

a) Ot jak Kamaedzica. Gavorac': na Kamaedzicu!... Ja čula i znaju, što takoe slova jo: Kamaedzica. A što za Kamaedzica? što-to takoe Kamaedzica... 'Na Kamaedzicu,' - kazhuc'! (Boganeva \& Varfolomejeva) Here's how Kamaedzica. They say: on Kamaedzica!... I heard and I know that there is such a word: Kamaedzica. And what kind of Kamaedzica? What is Kamaedzica... 'On Kamaedzica,' they say!

b) Колэдь, Колоедьца. Колоедьца, вона ж всю жьзнь вэдэица, кілько cвim йісьия. (Boganeva \& Volodina)

Komedy, Komojedyca. Komojedyca, it has always been [there], as long as the world is there.

It should be pointed out that the other record (see the information about its contents below) takes the bear rite-ritual practices outside of the borders of the south of the Viciebsk Region.

While there is no specific term, certain motifs (a special day for greeting the bear; a ritual action motivated by rendering assistance to the bear who is waking up from its winter sleep) are also present in the legend about the reincarnation of a man who wanted to scare God, into a bear, which was recorded comparatively close to the Biahoml area of the existence of the rite (Viliejka District of the Minsk Region): 
... u tym carstve ǔžo gjetkae s'vjata adzin dzen': pa zjamli kačajucca. Gjeta vedz'mjadzju pamagajuc'... [u] toj dzen', [u] katory vjadz'medz' nastrašyŭ Boga. (Boganeva \& Volodina)

... in that kingdom there is such a holiday on one day: they are rolling on the ground. It helps the bear ... on that day in which the bear frightened God.

Thus, there are reasons to claim that relevant practices related to bear days spread in Belarus much more widely than it had been believed before.

As for the ritual semantics of the Belarusian kamajedzicy, comparatively recent records from the Motal ethnocultural area of western Polesye (Psyščava, Ivanava District, Brest Region), which are directly correlated with the evidence found in the territories where the South Slavs / Balkan people lived, considerably expand the understanding of it and, most importantly, allow issues of more general character to be discussed. Stratification analysis of the record made in Psyščava allows the following scheme with respect to individual codes to be built:

- Temporal: St. Thomas Week (after Easter):

... buly takjee dni $v$ aprjeli misjacy. Na provody zymy ... Eto pos'lja Vjelykonnja Provodnaja nydilja nazyvajecca ... Zimu progonjaty, myd'vidja kormity... V etu nydilju progonijut' zymu. I ot vsjo gjeto robymo.

... there were such days in April. During the farewell of the winter... This is after Easter; it's called the farewell week... We drive out the winter and feed the bear... This week, they drive out the winter. And all this is done.

- Spatial: the backyard where people put food and drinks:

To i prychodyv [medved'] ... užje vin idje v silo, kob dje čym požyvytysja... [Korzinu s ugoščeniem stavili] na dvori. U chatu ž myd'vid' nje prydje. And so [the bear] came... already going to the village to get some food somewhere [the basket was set with a treat] in the yard. The bear does not come into the house.

- Culinary: wheat kliocki (dumplings), honey, kissel:

Vo gety galušky, vo gety komy... Tisto rosčynjajecca na droščjech, zamjesyty vrano, tak gustjen'ko nakačetje etych buločok maljen'kih, i vkydaju v vodu, a oni povsplivajut', takie puchkjen'ki... I takie vo kamy nazyvalysja... Tisto $v$ vodi varycca, to ž nazyvalosja galušky, i komy zvaly ich ... jogo ž [medvedja] trjeba ... nakormyty vsim tym: $i$ komamy, i mjedom, vsim kisjeljom. Here are these galušky, here are these komy ... The dough is prepared and raised, you should [knead] it early [in the morning], you'll make more small buns; and throw them into the water, and they float up, so fluffy ... And so these were called kamy... The dough is boiled, and it was called 
galušky, and komy also... it [the bear] must be fed with all this: komy, and honey, and kissel of course.

- Object-specific: a special basket:

Nu naklaly ž myd'vidjovy v kiš, da njechaj užje jist'.

They put it for the bear in the kosh [basket], and let him eat.

- Motivational:

a) greeting the bear as "the king of the forest":

Vin žje ž car lisu. Do jogo ž trjeba pryladytys', jogo ž trjeba šanovaty, odobraty, nakormyty...

He is the king of the forest. You should learn to deal with him, it is necessary to respect him, to collect [food], to feed him...

b) mollifying the bear as a precaution:

Šo kormyly mid'vidja, kob nje robyv porčy ljudjam... Tody ž [posle togo, kak ugostitsja] vin idje i nikomu porčy nje robyt'.

They fed the bear, so that he did not damage people... Then [after the treats] he goes and does not damage anyone.

Certainly, this invariant of ritual actions is a far cry from the "classical", Biahomí scenario, but instead it resembles the Macedonian, Serbian, and Albanian scenarios described above, which allows us to notice another Belarusian (Polesyan)South Slavic isodox of the bear day/festivity. It is also essential to point out obvious inconsistencies, the most important of which is related to the timing parameter. However, we should bear in mind the correlative ritual importance of New Year's Eve (Christmas Eve) in particular (and St. Vasily's (Basil's) Day at the same time), on the one hand, and St. Thomas Week (Farewell Week), on the other hand (we should also think about Biahoml's Eve of the Annunciation Day and Mid-Pentecost). All of these time periods actualize the basic temporal opposition of the beginning/end and optionally the beginning/middle/end.

The relation between the temporal code and the motivations behind certain "actions"/"behaviour" of certain actions ascribed to the object, i.e., to a bear (a she-bear) in both ethnocultural areas is of particular interest. Indeed, in the Balkan tradition, the New Year and New Year's Eve are related to birth (the new appearance of a bear cub); in the Belarusian tradition the Eve of Annunciation Day and Mid-Pentecost is the time related to the waking up of the bear after winter sleep as the new beginning of vital activity (Biahoml area), and St. Thomas Week is for the greeting of the bear and giving it treats, which in the Motal area is perceived as saying farewell (tody ž vin idje (then he goes)). It should definitely be pointed out that all of those three motifs are unique transformations of the overcoming of different kinds of the transition situation by the object (perhaps once being a totem). 
The comparison of the South Slavic/Balkan material with the new (western Polesyan) records, kamajedzicy also allows a question to be raised concerning the availability in the Belarusian ethnoculture of two interrelated parts of one single ritual of a bear day/festivity with its own ritual practices, one of which, namely the imitative one, was cultivated in the southern Paazerje in Belarus, while the second one, which generalizes the motifs of greeting and saying farewell, was practiced in central Zaharoddzje (western Polesye). It is worth mentioning that the first part is not represented in some ethnocultural areas of Slawiya even at the level of individual echoes, perhaps with the exception of ritual bear disguises and the existence of the pea ingredient in the culinary code, for example, during the bear days that take place on Saint Andrew's Day (30 November/13 December) (see Vinogradova \& Tolstaya 1995: 109-111 for additional information).

\section{CONCLUSION}

The material represented in the research, which manifests the ethnolinguistic equivalence based on South Slavic and Belarusian correlations at Christmas time and on bear days/festivities allows the historical borders of such equivalence to be objectified. In the first case, the entire set of correlations analysed, which are of clearly consistent nature, provides evidence of their common (late) proto-Slavic foundation and further genesis in the Slavic space of traditional spiritual culture. The comparison of South Slavic bear days/festivities and the Belarusian correlations suggest that in this case we are dealing with the phenomena of typological essence, since both for South Slawiya and for the Belarusian part of the eastern Slavic ethnocultural continuum, the different ways of worshipping the bear are the Indo-European (common European) heritage.

\section{ACKNOWLEDGEMENTS}

The article was written as part of a project financed by the Foreign Ministry of Estonia through the Developmental Cooperation Programme (66-2015-A). 


\section{NOTES}

1 It is very important to point out here that the ritual actions with a chump are also native for Belarusian traditional culture (see Antropov 1998: 21-33 for additional information).

${ }^{2}$ In the article (Tolstoi 1995) the evidence refers to north-western Belarus. However, its primary source is an anonymous ethnographic note from a geographically opposite region, namely from the Mahilioŭ (Mogilev) Governorate (see Sueveriya 1849: 100).

3 A distant but related parallel to the above-mentioned tradition is planting a birch log under the threshold of a new stable, which is also described in the same source as a peculiar fertility stimulator - "so that there would be plenty of horses" (Sueveriya 1849: 117).

4 Boiled rice with raisins and honey.

5 At this point, it should be brought to notice that on the basis of the analysis of the actions listed above, a fundamentally different motivational essence of the ritual Christmas log burning could be reconstructed, which actualizes the opposition of fertility/infertility: "Supposedly, burning wood in the fireplace partially acquired the function of purification. ... A fruitless tree that had been purified with fire became fructiferous" (Strakhov 2003: 162). In this context, curious is the evidence of the first heating of the new house (also with the purpose of preventing fire), which can be found in the record from the historical Mahilioŭ Region about heating up drying-houses with Christmas firewood - namely apple tree firewood (Sueveriya 1849: 100).

6 Thick porridge of coarse maize meal.

7 Interestingly, the same realia was observed in the southern German ethnocultural area: in Lüneburg (Lower Saxony), special breads in the shape of a bear were baked for Christmas, which were afterwards given away as gifts to wish the receiver success in the new year (Makovsky 1996: 215).

\section{MANUSCRIPT SOURCES}

Boganeva \& Varfolomejeva = Boganeva, Elena \& Varfolomejeva, Tamara. Ličnyje arhivy . [Personal Archives.]

Boganeva \& Volodina = Boganeva, Elena \& Volodina, Tatiana. Ličnyje arhivy. [Personal Archives.]

Volodina = Volodina, Tatiana. Ličnyj arkhiv. [Personal Archive.] 


\section{REFERENCES}

Antropov, Nikolai 1998. Belorusskie etnolingvisticheskie etiudy: 1. koloda/kolodka. [Belarusian Ethnolinguistic Studies: 1. koloda / kolodka.] In: T. Agapkina \& A. Zhuravlev \& S. Tolstaia (eds.) Slovo i kul'tura: Pamiati Nikity Il'icha Tolstogo. Vol. 2. Moscow: Indrik, pp. 21-33. Available at http://inslav.ru/publication/slovo-ikultura-pamyati-nikity-ilicha-tolstogo-m-1998-t-i-ii, last accessed on 18 May 2018. Antropov, Nikolai 2004. Ab etnalingvistychnaj ekvivalentnasci ŭ slavyanskih nekantaktuyuchyh arealah (belaruska-slavacki aspekt). [On Ethnolinguistic Equivalence in Slavonic Noncontact Areas (Belarusian-Slovak Aspect).] In: N. Kiseleva (ed.) O spoločných hodnotách v slovensko-bieloruských vztahoch: Zborník materiálov $z$ vedeckej konferencie Slovensko-bieloruské vztahy. Banska Bystrica: Poniky, pp. $75-84$.

Antropov, Nikolai 2007a. Kaštoŭnasnyja aryjenciry bielaruska-inšaslavianskaha etnalinhvistyčnaha paraŭnannia. [Value Orientations of the Belarusian-OtherSlavonic Ethnolinguistic Comparison.] Bielaruskaja linhvistyka [Belarusian Linguistics], Vol. 60, pp. 64-76.

Antropov, Nikolai 2007b. Traditsionnaia kartina mira v belorussko-bolgarskoi etnolingvisticheskoi prizme. [Traditional Worldview in the Belarusian-Bulgarian Ethnolinguistic Prism.] In: B. Norman \& N. Suprunchuka (eds.) Iuzhnoslavianskie iazyki $v$ ikh istorii i sovremennom sostoianii. [South-Slavic Languages in their History and Current State.] Minsk: Izd. I. P. Logvinov, pp. 10-18. Available at https://uploads.philology.by/ms/suprunchuk2007serb_gram_interact.pdf, last accessed on 18 May 2018.

Cychun, Genadz 1983. Paŭdnjovaslavjanska-ŭshodneslavjanskija moŭnyja suvjazi: Da prablemy slavjanskaga ŭkladu ŭ balkanski moŭny sajuz. [South-Slavic East-Slavic Linguistic Ties: On the Issue of Slavonic Contribution to the Balkan Language Area.] IX Mizhnarodny z'ezd slavistaŭ: Daklady. [9th International Assembly of Slavonic Scholars: Papers.] Minsk: Navuka i technika.

Debelković, Dena 1907. Običaji srpskog naroda na Kosovu Polu. [The Customs of the Serbian People in the Kosovo Field.] Srpski etnografski zbornik [Serbian Ethnography Collection], Vol. 7, pp. 171-332.

Elezović, Gliša 1932. Rečnik kosovsko-metohiskog dijalekta. [Dictionary of the KosovoMetohija Dialect.] Vol. I. Belgrade: Srpska kraljevska akademija.

Elezović, Gliša 1935. Rečnik kosovsko-metohiskog dijalekta. [Dictionary of the KosovoMetohija Dialect.] Vol. II. Belgrade: Srpska kraljevska akademija.

ERSJ 2003 = Etimološki rječnik srpskog jezika . [Etymological Dictionary of the Serbian Language.] Vol. 1. Belgrade: Institut za srpski iezik.

ESBM 1978 = Etymalagičny sloŭnik belaruskaj movy. [Etymological Dictionary of the Belarusian Language.] Vol. 1. Minsk: Navuka i technika / Belarus. navuka.

ESUM 1982 = Etymologičnyj slounyk ukrajins'koji movy. [Etymological Dictionary of the Ukrainian Language.] Vol. 1. Kyiv: Naukova dumka.

GSBM 1982 = Gistaryčny sloŭnik belaruskaj movy. [Historical Dictionary of the Belarusian Language.] Vol. 1. Minsk: Navuka i technika.

Gura, Alexandr 1997. Medved'. [The Bear.] In: N. Tolstoi (ed.) Slavjanskie drevnosti: Etnolingvističeskij slovar'. [Slavic Antiquities. Ethnolinguistic Dictionary.] Vol. 3, Moscow: Mezhdunarodnyje otnoshenija, pp. 211-215. 
Ivanov, Vyacheslav \& Toporov, Vladimir 1994. Medved'. [The Bear.] In: S. Tokarev (ed.) Mify narodov mira. [Myths of the World.] Vol. 2, pp. 650-651. Moscow: Sovetskaia Entsiklopediia. Available at https://www.indostan.ru/biblioteka/ knigi/2730/3412_1_o.pdf, last accessed on 18 May 2018.

Ivanova, Julia 1973. Albancy. [The Albanians.] In: S. Tokarev (ed.) Kalendarnye obychai i obriady v stranakh zarubezhnoi Evropy XIX - nachalo XX v.: Zimnie prazdniki. [Calendar Customs and Rites in European Countries outside Russia in the 19thEarly 20th Centuries: Winter Holidays.] Moscow: Nauka, pp. 299-307.

Kulišić, Špiro 1970. Badnjak. [Christmas Log.] In: Špiro Kulišić \& Petar Ž. Petrović \& Nikola Pantelić (comps.) Srpski mitološki rjecnik. [Serbian Mythology Dictionary.] Belgrade: Izdavachko preduzeћe Nolit, pp. 20-22. Available at https://www. scribd.com/doc/204003750/Srpski-Mitoloski-Recnik-Grupa-Autora, last accessed on 21 May 2018.

Licjvinka, Vasil 2001. Svjaty i abrady belarusaŭ. [Holidays and Rites of the Belarusians.] Minsk: Belarus.

Makovsky, Mark 1996. Sravnitel'nyi slovar' mifologicheskoi simvoliki v indoevropeiskikh iazykakh: Obraz mira i miry obrazov. [Comparative Dictionary of Mythology Symbols in Indo-European Languages: Worldview and Worlds of Views.] Moscow: Gumanit. izd. tsentr Vlados.

Nečajev, Simeon 1874. Prazdnik komoedicy. [The Holiday of Kamajedzica.] Minskie eparkhial'nye vedomosti [Minsk Diocesan News], Vol. 7, pp. 229-230.

PA = Polesskij arhiv Instituta slavjanovedenija Rossijskoj Akademii nauk. [Polesye Archive of the Institute of Slavic Studies of the Russian Academy of Sciences.]

Plotnikova, Anna 2004a. Pepel. [Ashes.] In: N. Tolstoi (ed.) Slavianskie drevnosti: Etnolingvisticheskii slovar'. [Slavic Antiquities: Ethnolinguistic Dictionary.] Vol. 3. Moscow: Mezhdunarodnyje otnoshenija, pp. 666-670.

Plotnikova, Anna 2004b. Etnolingvisticheskaia geografiia Iuzhnoi Slavii. [Ethnolinguistic Geography of the Southern Slawiya.] Moscow: Izd-vo Indrik.

Schneeweis, Edmund 1925. Die Weihnachtsbräuche der Serbokroaten. Vienna: Verlag des Vereines für Volkskunde.

Schneeweis, Edmund 1961. Serbokroatische Volkskunde: Volksglaube und Volksbrauch. Erster Teil. Berlin: De Gruyter.

Seržputoŭski, Aljaksandr 1998 [1930]. Prymhi i zababony belarusaŭ-paleshukoŭ. [Superstitions and Prejudices of the Polesye Belarusians.] Minsk: Universiteckaje.

Shein, Pavel 1902. Materialy dlia izucheniia byta i iazyka russkogo naseleniia SeveroZapadnogo kraia. [Materials to Study the Lives and Language of the Russian Population of the North-Western Land.] Vol. 3. St. Petersburg: Tip. Imp. AN. Available at http://books.e-heritage.ru/book/10084991, last accessed on 21 May 2018.

Shelud'ko, Dmytro 1931. Nimec'ki elementy v ukrajins'kij movi. [German Elements in the Ukrainian Language.] Zbirnyk komisiji dlja doslidžennja istoriji ukrajins’koji movy. [Collection of the Commission on the Studies of the History of the Ukrainian Language.] Vol. 1. Kyiv.

SP 1974 = Stownik prastowiański. [Common Slavic Dictionary.] Vol. 1. Wrocław: Ossolineum. 
SRJ 1975 = Slovar' russkogo jazyka XI-XVII vv. [Dictionary of the Russian Language of the 11th-17th Centuries.] Vol. 1. Moscow: Nauka. Available at http://etymolog. ruslang.ru/doc/xi-xvii_1.pdf, last accessed on 21 May 2018.

Strakhov, Alexandr 2003. Noch' pered Rozhdestvom: Narodnoe khristianstvo i rozhdestvenskaia obriadnost' na Zapade i u slavian. [Christmas Eve: Folk Christianity and Christmas Rituals in the West and in Slavic Cultures.] Palaeoslavica, Vol. 11, Supplementum I.

Sueveriya 1849 = Sueveriia i predrassudki v Mogilevskoi gubernii. [Superstitions and Prejudices in the Mahilioŭ Governorate.] Mogilevskie gubernskie vedomosti [Mahilioŭ Governorate News], No. 6, pp. 99-100; No. 7, pp. 117-118; No. 8, pp. 138-140.

Tolstaya, Svetlana 1986. Polesskii narodnyi kalendar': Materialy k etnodialektnomu slovariu. [Polesye Folk Calendar: Material for the Ethnic Dialect Dictionary.] In: L. E. Kalnyn' \& T. N. Moloshnaia (eds.) Slavianskoe i balkanskoe iazykoznanie. Problemy dialektologii: Kategoriia posessivnosti. [Slavonic and Balkan Linguistics Problems of Dialectology.] Vol. 10: D-I. Moscow: Nauka, pp. 98-131.

Tolstaya, Svetlana 2005. Polesskii narodnyi kalendar'. [Polesye Folk Calendar.] Moscow: Indrik. Available at http://inslav.ru/publication/tolstaya-s-m-polesskiy-narodnyykalendar-m-2005, last accessed on 21 May 2018.

Tolstoi, Nikita 1986. Balkano-slavianskii badniak v obshcheslavianskoi perspektive. [The Balkan-Slavic Badnjak in the Common Slavic Perspective.] In: V. Ivanov \& V. Neroznak \& V. Toporov \& T. Tsiv'ian (eds.) Balkany $v$ kontekste Sredizemnomor'ia:Problemy rekonstruktsii iazyka i kul'tury. Tezisy i predvaritel'nye materialy $k$ simpoziumu. [Balkans in the Context of the Mediterranean Region: Problems of the Reconstruction of Language and Culture.] Moscow: Nauka, pp. $128-131$.

Tolstoi, Nikita 1995. Badnjak. [Christmas Log.] In: N. Tolstoi (ed.) Slavianskie dreunosti: Etnolingvisticheskii slovar'. [Slavic Antiquities: Ethnolinguistic Dictionary.] Vol. 1. Moscow: Mezhdunarodnyje otnoshenija, pp. 127-131.

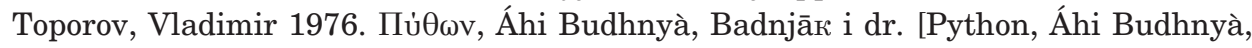
Badnjak, and Others.] In: O. N. Trubačev (ed.) Etimologija 1974. [Etymology 1974.] Moscow: Nauka, pp. 3-15.

Varlyha, Adam 1972. Zababony. [Superstitions.] New York: Zaranka.

Vasilevich, Uladzimir 1998. Žyccja advečny lad: Belaruskija narodnyja prykmety i paverï. [The Eternal Way of Life: Belarusian Folk Signs and Beliefs.] Vol. 2. Minsk: Belarus.

Vinogradova, Liudmila \& Tolstaya, Svetlana 1995. Andrej. N. Tolstoi (ed.) Slavianskie drevnosti: Etnolingvisticheskii slovar'. [Slavic Antiquities: Ethnolinguistic Dictionary.] Vol. 1. Moscow: Mezhdunarodnyje otnoshenija, pp. 109-111.

Vukanović, Tatomir P. 1986. Srbi na Kosovu. [The Serbs in Kosovo.] Vol. 2. Vranje: Nova Jugoslavija.

Zajkoŭski, Edvard \& Sanjko, Sjarhej 2004. Mjadz'vedz'. [The Bear.] In: S. Sanjko (ed.) Belaruskaja mifalogija: Encyklapedyčny davednik. [Belarusian Mythology: Encyclopaedic Reference.] Minsk: Belarus, pp. 333-336. 


\title{
CONTEMPORARY RECORDINGS OF BELARUSIAN FOLK BIBLICAL AND NON-BIBLICAL ETIOLOGICAL LEGENDS IN THE COMPARATIVE-HISTORICAL ASPECT
}

\author{
Elena Boganeva \\ Center for Belarusian Culture, Language and Literature Research \\ National Academy of Sciences, Belarus \\ e-mail: elboganeva@gmail.com
}

\begin{abstract}
The article considers some rare etiologies in contemporary recordings - non-biblical cosmogonic and folk biblical anthropogenic etiologies in the comparative and historical aspect. Cosmogonic etiologies are stories about the predetermination of spatial and temporal parameters of the world (texts about the origins of the elements of the earthscape, in particular, mountains; about the agreement made between God and Satan concerning the distribution of ascendancy over people at the beginning of the world and at the end of it; about the determination of the time of the existence of the world and the change of time); about the structure of the current status of the Universe (the Earth is round, it revolves and is supported by a giant turtle or tortoise); about the primary entity or body, from which the following emerges: the world (out of a child's body), a part of cultural space - a group of inhabited localities (out of a felled statue), and one of the primary elements - fire (out of a human). Anthropogenic folk biblical etiologies include stories about the origins of sexual relations between the first people (two versions); the birth of children out of different body parts (the head, through the side of the body); and the origins of hair on male bodies.
\end{abstract}

Keywords: anthropogenic etiologies, etiological legend, etiologies of cosmogonic legends, folk Bible, folk biblical etiologies, folk narratives, non-biblical etiologies, vernacular Christianity

\section{INTRODUCTION}

According to its administrative division, there are 6 regions (oblasts) and 118 districts in Belarus. Archaic forms of folklore can be collected in Belarus even to this day. Among other texts, the collected pieces include new additions to etiologies, the earlier versions of which were mainly collected at the beginning of the twentieth century and no longer exist in the living heritage of many European countries. One of the purposes of folklore studies in Belarus has 
been the ethnolinguistic mapping of mythical and religious lore and in-depth studies of the material that includes vernacular Christianity.

The purpose of this article is an analysis of contemporary recordings of the etiologies of Belarusians. Etiological legends explain the origin of things as well as the properties and the peculiarities of the world, living creatures, natural and cultural objects, customs and traditions, social attitudes, taboos, and orders, and give answers to numerous "why" and "where from" questions. ${ }^{1}$

Etiological folktales have to do with biblical characters, elements, and motifs that are related to the Old Testament and the New Testament, Apocrypha, and other oral and written Christian tradition or mythology in general. Other etiologies do not usually relate directly to the Christian texts or the Bible, biblical events or characters, although some of them do. For example, the origins of storks, reasons for shortening down the ears of grain, for why a woman is always busy, etc., are not uncommonly incorporated into oral biblical narratives. ${ }^{2}$

In order to achieve the purpose of the research, the following tasks should be accomplished: exploring the main concepts and terms that are used in the article; providing a brief description of the history of the research object and publications within the international and Belarusian context. The main part of the article analyses contemporary etiological legends, including cosmological stories with a background in vernacular Christianity and mythology, stories related to genesis and the end of the world, and also part of anthropogenic legends. The comparative historical method is used in the article to analyse the material. The presented material includes several new and rare, single variants of etiologies.

\section{PUBLICATIONS AND RESEARCH}

In comparison to fairy tales, etiological legends are poorly studied corpora of texts. At the end of the nineteenth and beginning of the twentieth centuries, a number of regional studies were conducted within the territory of Belarus, as a result of which fundamental corpora of folklore texts were published, including popular prose with a substantial proportion of etiological legends, both biblical and non-biblical. These collections were compiled by Vladimir Dobrovol'skiy (1891), Yevdokim Romanov (1891, 1912), Pavel Sheyn (1874, 1893), Michał Federowski (1897), Aleksandr Serzhputovskiy (1911, 1930), Czesław Pietkiewicz (1938), and others. These collections contain a rich and varied set of texts, and their classification system, skilful delivery of the characteristics of dialects, and the personal touch of a storyteller have, in the long run, become benchmarks for regional publications; they have not faded from importance even today. 
In Soviet times, starting from the 1930s, throughout the Eastern Slavic countries and later also in the countries of the "socialist camp", legends (also memorates and any kind of genre varieties telling about supernatural forces mythological fairy tales, stories about miracles, mythological stories about God's help and punishment) were on the fringes of research interest due to their "religiousness" and "reactionism". In the volume Legendy i padanní (Legends and Stories), published by Grynblat and Gurskiy in 1983 as a part of the Belarusian academic series Folk Art, consisting of 47 volumes, almost the entire corpus of biblical and non-biblical legends is made up of records written by Vladimir Dobrovol'skiy, Yevdokim Romanov, Pavel Sheyn, etc., made at the end of the nineteenth and the beginning of the twentieth centuries. In the foreword to the second edition of this scientific work published in 2005, Mikhail Grynblat and Anton Gurskiy point out that, "as a matter of fact, Belarusian folk legends and stories are still poorly studied. There have been no separate works dedicated to the Belarusian legends and stories until recently. The first steps in this field are just being taken" (Grynblat \& Gurskiy 2005: 11).

Researchers started taking meaningful interest in etiological legends in the last decades of the twentieth century. One of the first national publications about etiologies was the collection of the Lithuanian author Norbertas Vèlius, titled Kaip atsirado žemé: lietuviu etiologinès sakmès (How the Earth Appeared: Lithuanian Etiological Legends) (Vèlius 1986), which was translated into English and published later (Vèlius \& Dapkute \& Kupcinskaite 1998). The research of Marlène Albert-Llorka, L'ordre des choses: Les récits d'origine des animaux et des plantes en Europe (The Order of Things: European Stories about the Origins of Animals and Plants), was also of considerable importance in terms of stimulating scientific interest in etiologies (Albert-Llorka 1991).

Purposeful collection of such texts in the post-Soviet period started in the second half of the $1990 \mathrm{~s}$, within the framework of the inter-institutional and interdisciplinary scientific programme of the research of the territories of Belarus, titled The Current State of the Traditional Culture of Belarus, in which scientists from different institutions (including the Academy of Sciences of Belarus) and representatives of various branches of science (ethnologists, folklorists, ethnomusicologists, ethnochoreographers, art experts, etc.) participated. ${ }^{3}$ The programme provided for field research in every district of Belarus with as extensive coverage of the territories as possible. Series of questionnaires were initially developed in line with the methodology of the research, which were related to different types of traditional culture, including popular prose (Boganeva 1998). Questionnaires were mainly compiled on the basis of the publications issued at the end of the nineteenth and beginning of the twentieth centuries, and they were purposefully "verified" in the process of regional research. 
In Belarus, within the framework of the regional studies of the current state of Belarusian folklore tradition, in 2002-2013, a 10-volume series called Traditional Artistic Culture of Belarusians was published, which had chapters about etiological legends (both non-biblical and biblical) ${ }^{4}$ (Tradytsyynaya 2004: 719-724, 752-761; Tradytsyynaya 2006: 348-399; Tradytsyynaya 2009: 373-439; Tradytsyynaya 2011: 384-454; Tradytsyynaya 2013: 526-611).

Ten years later, the team of contributors within regional studies published 20 specified and revised collector programmes pertaining to different types and genres of traditional culture, including popular prose (Boganeva 2008a), folk Bible (Boganeva 2008b), and folk Orthodoxy (Boganeva 2008c). It is in the course of the fieldwork in different districts of Belarus that it became clear what kind of biblical and non-biblical legends are "massive", which ones are rare, and which of them were recorded as individual cases. ${ }^{5}$

A considerable contribution into the research and publication of etiological texts was made by such recent publications as the multi-authored (both foreign and Russian researchers) monograph called Contes et légendes étiologiques dans l'espace européen (Etiological Fairy Tales and Legends in the European Context) under the editorship of Galina Kabakova (2013) as well as a collection of etiological folklore texts of the nineteenth-twenty-first centuries with extensive commentaries, called $U$ istokov mira: Russkie etiologicheskie skazki i legendy (At the Origins of the World: Russian Etiological Legends and Fairy Tales) (compiled and commented on by Olga Belova and Galina Kabakova) (2014).

\section{TERMINOLOGY: EMIC AND ETIC TERMS}

To designate oral folktales on biblical topics, the term folk Bible has become the most common in Slavonic studies, and this is exactly how the corpora of oral biblical texts were called by the Poles (Zowczak 2000, 2013), the Russians (Belova $2004)^{6}$, the Macedonians (Vrazhinovski 2006), and the Belarusians (Boganeva 2010). ${ }^{7}$ The researchers use also the terms "the rural Bible" (Lammel \& Nagy 1985), "the Bible for the poor" (Lapucci 1985), "the folklore Bible" (Badalanova 1994, 1997-1998), "parabiblical folklore" (Lammel \& Nagy 2005), etc. ${ }^{8}$ In the opinion of Magdalena Zowczak, "the most emphatic term, 'folk Bible', came into use as a result of shifting the field of attention and concern of the humanities towards the phenomenon of 'frontier' cultures and the changes that are taking place as a result of migrations and the mixing of cultures. Studying the 'folk Bible' is similar to being interested in apocryphal stories, which is an example of both a shift in cultural discourse and changes in culture itself throughout the territories of post-communist countries" (Zowczak 2013: 9). What is meant 
here is not only and not so much the territorial and geographical frontier, but rather the "frontier" cultural phenomena. In conclusion, the folk Bible is "on the borders" between oral and literary traditions, the canon and the Apocrypha, Christianity and archaic worldview paradigms.

In emic terms, the oral texts on biblical topics and with biblical plots are defined by rural informants in a depictive way, referring simultaneously to the oral tradition and a written source - either the Bible or the Law of God. ${ }^{9}$ For example, when retelling a biblical story of the Creation, the informant says ${ }^{10}$ :

Tak yana, mama, raskazyvala. Yana gavaríla, shto $k$ ím u shkolu u Studzyantse byŭ príkhod, i $k$ im batsyushka kozhnuyu nyadzelyu príkhadzíŭ i chytaŭ Zakon Bozhy. ${ }^{11}$

This is what Mum told me. There was a parish in Studenets, and she said that a priest would visit them every week and read the Law of God.

Below the informant answers the collector's question about who Adam and Eve were.

Adam, pa Bíblíi píshetstsa, suyashchenník. A Yeva-Míkoly Chudatvortsa matsi. ${ }^{12}$

Adam, according to the Bible, was a priest. And Eve was the mother of Saint Nicholas the Wonderworker.

As for the emic definition of non-biblical etiologies, according to my field observations of twenty years, they were referred to as anecdotes, parables, fairy tales, and sometimes even embellishments, without any precise meaning being read into those definitions. However, even if referring to etiological legends as fairy tales and anecdotes, as a rule, the bearers of tradition believe that they describe true events which happened an indefinitely long time ago, "when God walked the earth". ${ }^{13}$

A legend is not a term of folk origin, which is why, while collecting material, collectors have to ask questions related to plots, main characters, and etiological morals of popular legends: "Why can't a stork be killed?"; "Do they say that a stork (a cuckoo, a bear, etc.) comes out of a human?"; "Why is the aspen shaking?"; "Why does a swallow have a swallowtail?"; "Why doesn't a human know the time of his or her death?"; etc.

By answering such questions, storytellers open up different meanings in narratives, for example, discuss the relationship of truth-value and fantasy in stories. For example, the initial response to such questions among informants was quite similar - a forbearing smile would appear on their faces, as if it was about something trifling and not too serious. However, after hearing a legend followed by a question about whether it was the truth or a fairy tale, they would 
seriously say that it was not a fairy tale but rather the truth. For example, after hearing the legend about how God puts people into couples (one person in the couple is lazy, while the other one is hard-working), the informant starts reasoning about the "truthfulness" of this legend, and then suddenly notices a voice recorder in the collector's hand, which she had not paid attention to before.

'Nu yano mozha í praŭdu tak. Praŭda. Yany... Tak Vy mozha zapísyvayetse tu yerundu, shcho ya gavaru?' - 'A vy dumayetse, shto geta: yerunda abo praŭda?' - 'Nu... kali geta raskazvali stareyshyya lyudzí.. Tak geta $z$, peŭna, praŭda bylo!'14

'It might be true. Really. They... Are you recording the nonsense I'm saying?' - 'What do you think it is: truth or nonsense?' - 'Well... considering that the old people told us these things... It was the truth, of course!'

At the start of telling a rare etiological tale about differences between sexes, the informant claims straight away:

Eta, dzítsyatka, praŭda. Eta praŭda. Eta yak s'vet asnoŭvaŭsya, geta, dzítsya, praŭda. Eta ne skazka, ne. Eto praŭda, mílaya maya, tak vo tak. ${ }^{15}$ (Tradytsyynaya 2011: 389-390)

Yes, child, this is true. It's true. This story about the creation of the world is true. It's not a fairy tale, no way. It's true, my darling, yes, it is.

It means that in the perception of contemporary informants, legends have a dual status. On the one hand, they are not taken very seriously these days, since axiologically, they are more "inferior" with regard to the Holy Bible, for example (although in the oral tradition, the former is often mixed with the latter), but on the other hand, these are texts that are consecrated through tradition; they explain world phenomena, instruct, and, thus, are of extreme importance for the bearers of the tradition. Maybe this is the reason why etiological texts have been preserved in the rural traditional culture of Belarus until the present.

\section{COSMOLOGICAL LEGENDS, GENESIS: DISTRIBUTION OF AND PARALLELS TO ETIOLOGICAL STORIES}

Among the plots of etiological legends (folk biblical and non-biblical), recorded in the territory of Belarus in recent years, the most typical and widespread predominate, such as those about the origins of storks, cuckoos, bears, pigs, turtles, about a ban on killing spiders, the spots on the Moon, about why a woman is always busy, why humans do not know the time of their death, why a child 
does not walk until he or she turns one, why horses never eat their fill, cows do not work, the aspen tree is shaking, alder trees have red bark, the reasons for shortening the ear of grain (dogs' and cats' fate), etc. All of these plots have parallels in the Baltic and Slavic countries, while sometimes their geography can be even wider than that (see Berezkin \& Duvakin; Vèlius \& Dapkute \& Kupcinskaite 1998; Kerbelite 2001; Belova 2004; Badalanova Geller 2008; Zowczak 2013).

In addition to that, in the course of the past 20 years, some rare, single etiologies have also been recorded in the territory of Belarus, many of which have direct and indirect counterparts in the folklore of Slavic, Balkan, and Baltic people as well as in non-Slavic and non-European traditions. Today the most popular cosmogonic plots are folk biblical: about how God created the world in stages, day after day (Boganeva 2010: 14-15). In Western and Central Polesye there are legends about "how a spider whisked the light" (Tradytsyynaya 2009: 373-374; Tradytsyynaya 2013: 585-586). Many other etiologies also have parallels in the folklore of different nations. The collection efforts made in the last decade have broadened our existing knowledge of genesis stories. We have seen the addition of several dualist creation motifs, and there are interesting parallels between several oriental traditions, according to which the world is created by dividing up a (human) being. Parallels to this motif can also be found in Slavic and other traditions. Such motifs include, for example: the origins of the Earth's relief (the devil scatters mountains, competing with God); the world order (the Earth is round, it revolves and is supported by a giant turtle or tortoise); the change of time (angels "added" 200 extra years of existence to our world); how God allowed Satan "to rule the world" and how things turned out; the genesis of the world from the body of a child; the genesis of a group of villages from a huge statue that broke into pieces; the genesis of fire from the body of a man. Let us have a closer look at each of these etiologies.

In 2012, a rare, in terms of current existence, recording of the legend about the origins of the Earth's relief was made:

Kazali kolís': Bog posporyŭ z chortom. Chort zha tozhe byŭ na nebesakh. A Bog yogo odtul' s'kínuŭ. Dak vun yek padaŭ na zemlyu, dak polovínu z'vozd khvostom zamoŭ. Dzed raskazyvaŭ. Dzed khodzíŭ u tserkoŭ, dzesyats' kílometraŭ peshkom khodzíŭ. 'A chago yon yago skínuŭ?' - 'Nu dyk Bog uzyaŭ sílu bol'shuyu za yago. A dali yany posporylí, stali sypats'... Chort staŭ sypats' gory. A voda byazhyts' s'lizits', a treba yekhats' choŭnom, a yedze cholovek, pkhayetstsa, pkhayetstsa da kazhe: 'Ot chort nasypaŭpovuchaye yego.' A potym: 'Slava Tabe, Gospadzi, shto ya pereyekhaŭ!' Von yamu ne ponravílas'. ${ }^{16}$ (Tradytsyynaya 2013: 585) 
They said that once God argued with the devil. The devil would live in heaven in those days, too. And God cast the devil from heaven. When he fell down, he swept away half of the stars from the sky with his tail. My grandfather told me. My grandfather would go to church, ten kilometres on foot. 'Why did He cast down the devil?' - 'God took great power for him. And they started arguing and scattering... The devil started scattering mountains. And the water runs like tears, and the man has to go by boat. He goes by boat and bumps against those mountains and says: 'The devil scattered those mountains!' - he swears at the devil. And then: 'Thank God! I crossed it!' The devil didn't like it.

The dualistic motives are very well pronounced in this legend - the joint creation of the world by God and devil. Among Belarusians, the legends with full-fledged dualistic motifs, where the devil takes soil from the sea bottom to create land, "spoils" the earthscape with marshes and mountains, "spoils" humans with diseases, tries to create some animals (wolf, goat, horse, and others, but cannot make them alive without God), were on numerous occasions recorded at the end of the nineteenth and beginning of the twentieth centuries by Belarusian folklorists and ethnologists Pavel Sheyn (1874: 428-429; 1893: 340-342), Yevdokim Romanov (1891: 1-10, 153-158), Vladimir Dobrovol'skiy (1891: 230-240), Aleksandr Serzhputovskiy (1911: 171-173), and others. At the end of the nineteenth and beginning of the twentieth centuries, this type of plot was repeatedly recorded among the Belarusians, Russians, Ukrainians, Bulgarians, Serbians as well as among non-Slavic ethnoses inhabiting Russia (the Karelians, Finns, Udmurts, Mordovians, etc.) (Kuznetsova 1998; Badalanova Geller 2011; Grynblat \& Gurskiy 1983: 32-64; Belova \& Kabakova 2014: 22-48). At present, dualistic plots have become irrelevant for the bearers of tradition and only rarely pop up in etiological legends (both non-biblical and folk biblical).

A text about who rules the world, recorded in the village of Byvalki, Loyevsky District, Gomel Region, in 2011 also belongs to ambivalent plots about the beginning and the end of the world at the same time.

A Bog skazaŭ satane: 'Nyakhay kíruye! Khay kíruye getymí lyudz'mí..' I ŭzho ne Bog kíruye, a satana nashym maladym narodam. Bo yany ŭ blud payshlí. Getaya garelka - ŭso! Na pervym plane adna vodka. Í ní rabota ím ne nada, ní dzetsí, níchavo. Yany paturavali dzyatsey z-za garelkí. 'Tak geta Bog dazvolíŭ satane kíravats' getym svetam?'- 'Da, Bog. A skora pryydze, shto Bog budze kíravats'. Skora pryydze, vot-vot, shto Bog budze kíravats'.' Yon skazaŭ, razrashyŭ yamu: 'Kíruy, pabachym, shto budze.' Nu tak i vot shto robitstsa. ${ }^{17}$ (Tradytsyynaya 2013: 585). 
And God said to the devil: 'Let him rule! Let him rule all of those people!' And God no longer rules, but the devil rules our youth. Because they indulge in lust. It is all because of vodka! Vodka is always on top. They don't want a job, kids, they want nothing. They get rid of their children because of vodka. 'Has God allowed the devil to rule the world?' - 'Yes, God. But very soon God will resume his rule. He told him, allowed him: 'Go on, rule! We'll see what happens.' And this is what's happening...

The narration can be perceived as eschatological, all the more so if it is told within the context of a talk about eschatology. However, there are no predictions about the end of the world and the coming of the Antichrist in the text. On the opposite, there is a prophecy saying that the world will soon be ruled by God again because the devil has not managed "to be a good ruler". There is also a parallel to the teaching of the Bogomils which said that Satan (Sataniel) subdued mankind completely, and his rule will reign on the Earth for a very long time, until God releases mankind from the power of Satan (Yastrebov 1993: 269-274). It is more rational to consider this text not as eschatological, but as a dualistic legend about the beginning of times, when a decision was made about who is going "to rule these people" and for how long.

The text about the world being supported by a huge turtle (or tortoise) is rare in contemporary recordings.

'Na chym svet staits'?'... 'Cherepakha dzerzhyt. Vona krutsitstsa zemlya, krutsitstsa, staryye baby kazali...' - 'A yakaya yana, kruglaya? Tsí ploskaya?' - 'Kruglaya, kazali. Kruglaya i krutsítstsa. Na cherepasi.' ... 'A nebo vzhe yak dzerzhytstsa... Kazhut, yak budze konchyna s'vetu, to vono vzhe upadze. I vsekh uzhe...' - 'A khto yago trymaye toye neba? Chago yano ne padaye?' - 'Kazhe, vono v vozdukhu, vozdukh dzyarzhyt. Kazhut, tam yanguly letayut, tamaka dushy lyudzey, baby roskazuvali... $O$, dushy poshli - eto yak cholovek umer - na nebesa. Na nebe vzhe dusha. Tulovíshche budze gnítsí, a dusha budze na nebi letats'. Dusha letaye. ${ }^{18}$ (Tradytsyynaya 2009: 373)

'What does the world stand on?' ... 'On a turtle. It goes round and round, the old women said...' - 'What is it like - round or flat?' - 'They said it was round. It keeps on going round and round. On the back of the turtle. And the sky is holding on... They say when the end of the world comes, the sky will fall down. And all of us will be...' - 'Who is holding the sky? Why doesn't it fall down?' - 'They say it's in the air, the air is holding it. They say there are angels flying over there, people's souls, the old women said. Yeah, souls, when a person dies, his soul goes to heaven. The soul 
is in heaven. The body will rot, and the soul will be flying around in heaven. Souls can fly.'

A contemporary text about the Earth being supported by a turtle (tortoise) is rare among Belarusians not only with relation to contemporary recordings. In the popular versions of cosmogonies, in the recordings that date back to the nineteenth and beginning of the twentieth centuries, made in the territory of Belarus, the Earth stands on a fish (Serzhputovskiy 1930: 22; Federowski 1897: 162), on three or four whales (Romanov 1912: 292; Serzhputovskiy 1930: 21-22), or on a chicken leg (Federowski 1897: 162-163). A turtle was not involved in those recordings.

In addition to the contemporary text cited above, another recording about a turtle holding the world, made in Belarusian territory (Eastern Polesye) is available:

Zyamlya na cherepasí. Yana bula bu ŭuzh, bu zhaba. Bog yey nakinuŭ cherap. ${ }^{19}$ (Sudnik \& Tsiv'yan 1982: 146)

The Earth on the turtle. It was like a grass snake, like a toad. God put a skull on it.

In these recordings, there is a good reason why a turtle appears as an image of the Earth's anchorage: firstly, two known recordings were made in Polesye, which, in addition to being regarded as one of the most archaic Slavic areas (see Tolstoy 1983: 6-8), is also the northern part of the natural habitat of the fresh-water turtle (see also Boganeva 2012: 104-107). Secondly, the turtle is a widespread zoomorphic character in the cosmogonies of different Eurasian peoples and of the Indian tribes in North America (see Berezkin 2005: 251-279; Sharakshinova 1980: 26). Herewith the distribution can be regarded as typological, ${ }^{20}$ since the image of a turtle, whose shell can carry a load that exceeds its own weight many times, is perfectly suitable for functioning as a support for a load as huge as the Earth itself.

It is commonly known that cosmogony often transgresses into eschatology and the other way round. In recent years, we have been able to observe many times how a storyteller, beginning to talk about the last times, moves on to talking about the Creation. Or, while attempting to describe the world order cosmography - proceeds to talk about the last times. A contemporary text about a turtle holding the world, cited above, is not an exception in this sense either. In this text, the description of the world state and order (the Earth is round, it goes round, and lies on the turtle) moves on to informing the listener that "when the end of the world comes, the sky will fall down", followed by a transgression from a "collective" eschatology to an individual one, i.e., what happens to a person after his or her death. 
A plot about the genesis of the Earth from the body of a child is typical neither for Belarusian folklore nor for any other Slavic or even European peoples.

Vygan vyalikí.. Neyak raskazana... at veku bylo eta. Zhyvoga ryabonka nayshli malen'kaga, i tady svet zavoŭsya. A khto nayshoŭ, yak geta - ne pomnyu. ${ }^{21}$ (Tradytsyynaya 2004: 758)

There was a large pasture (field)... They said... Since the beginning of time. They found a little baby who was alive, and this is how the world started. I don't remember who found it and how.

In spite of its uniqueness, this plot does not seem random or accidental, but it appears to be quite typological or even archetypal, since the motif of the genesis of the world from the body of a child (a human) is intrinsic in a huge number of mythologies throughout the territories of Asia, Africa, Oceania, and South America (Berezkin \& Duvakin: B2A; B2C). ${ }^{22}$ Incidentally, in terms of its meaning, the recording made in Belarus turns out to be quite close to another type of etiological texts - the world emerging from the body of the first human (Purusha) ${ }^{23}$ (Berezkin \& Duvakin: B43). Besides, this text correlates with a cosmogonic fragment of the Russian spiritual poem, Golubinaia Kniga ${ }^{24}$ in which the world is created from the body of Christ.

U nas belyy svet ot Svyata Dukha, Samavo Khrista, Tsarya Nibesnyva; Sontsa krasnyya ot litsa Bozh'iva, Samavo Khrista, Tsarya Nebesnyva; Mlad-svetol mesyats ot grudey Bozhiikh, Samavo Khrista, Tsarya Nebesnyva; Nochi temnyya ot volos Bozhiikh, Samavo Khrista, Tsarya Nebesnyva; Zori utrenni ot riz Bozhiikh, Samavo Khrista, Tsarya Nebesnyva; Zvezdy chastyya ot ochey Bozhiikh, Samavo Khrista, Tsarya Nebesnyva; Buyen veter ot dykhaniya Bozh'yego, Samavo Khrista, Tsarya Nebesnyva; Drobon dozhzhik iz sloz Bozhiikh, Samavo Khrista, Tsarya Nebesnyva. (Vlasova 1986, № 5: 10-16)

The wide world is from the Holy Spirit, Christ himself, the Heavenly Father; the Sun is from God's face, Christ himself, the Heavenly Father; the young bright moon is from God's breast, Christ himself, the Heavenly Father; the dark nights are from God's hair, Christ himself, the Heavenly Father; the morning dawn is from God's garments, Christ himself, the Heavenly Father; the stars are from God's eyes, Christ himself, the Heavenly Father; the tempestuous wind is from God's breath, Christ himself, the Heavenly Father; the fine rain is from God's tears, Christ himself, the Heavenly Father. 
The famous apocryphal Story of the Creation of Adam by God ${ }^{25}$ has the same plot, which is reversed: it is not the world that is created from human body, but a human body is created from the elements of the world.

[This is how God made a man]: 1) the body was made from soil; 2) bones were made from stones; 3) blood was made from the sea; 4) eyes were made from the sun; 5) thoughts were made from clouds; 6) light was made from light; 7) breath was made from wind; 8) warmth was made from fire. (Pypin 1862)

Thus an individual Belarusian recording turns out to be incorporated into the tradition of ancient Russian mythological and apocryphal texts, in which the world does not simply correlate with the human body, but is linked to it under the genesis principle.

One more text correlates with the previous one about the genesis of the world with the genre that can be classified as toponymic stories. ${ }^{26}$ This is a tale about the origins of the names of a group of villages - Tsytskovichi, Grudkovichi, Cherepa, Golovichi, Gornovschina, Puzovo, Ridkovichi, Zubki, etc., in Kletsk District, Minsk Oblast. ${ }^{27}$

Nekali statuya byla, ... i yaye razbílí. ... Yak u pushku ŭsorna ŭpustsílí, yana yak bukhnula. Í dze shto nashlí, tam vosku pastavíli. Eta zh ran'shy-ryn'shy bylo. Vot ye Rudkovíchy, Grudkavíchy... Rukí. Puzava nekali bylo, u nas Tsytskavíchy, shto nashli, Charapy - cherap galavy nashlí tam. Galavachy-galava tozha. Gornaŭshchyna, vrodze ad grudzí. Puzava - puza. Í Zubkí yos', my myazhuyemsya z ímí. Yano razbílasya tut nedaloka. ${ }^{28}$ (Tradytsyynaya 2011: 462)

There was a statue once, ... then it collapsed. ... They hit it from a cannon, and it was gone. And they built a village in every single place where they found pieces of the statue. It was a long, long time ago. We have Rudkovichi, Grudkovichi - arms. There was Puzovo, Tsytskovichi. Cherepa - they found a skull there. Golovichi - they found a head. Gornovschina - from the breast. Puzovo - belly. And we have Zubki, too, we border with them. It crashed right here, nearby.

Just like the myths about the creation of the Earth from the human body, in this story, a significant feature is the creation of a specific utilized cultural space (villages) from a cultural object (a statue). Herewith we should pay attention to the fact that while in the previous etiology the world was created from a living child (just like in Golubinaia Kniga, where the world is created from living Christ), in the toponymic story the statue collapsed, and its parts 
were scattered all over a specific area. In this respect, it is the story that corresponds to the type of etiologies labelled "Purusha" by Berezkin and Duvakin (B43) much more than the legend about the found child.

\section{LEGENDS ABOUT THE END OF THE WORLD}

Let us go back to stories about the end of the world. In 2012, a detailed narrative about the end of times was recorded:

Í ŭ Yago [Khrysta] bylo atabranykh lyudzey, yakíya bylík Bogu. A ŭ satany bylo mala. Í yon zaplakaŭ, satana yetyy, shto, mol, $k$ Tabe ŭso. A Yon gavoryts': 'Pad kanets use buduts' tvaye. A Mne takaya chas'tsichka tol'ki budzets', yak u tsyabe sychas.' Tak yano i yos'ts'. Ne verats'. Ran'she $z h$ Bogu malílís', bayalisya... ${ }^{29}$

And he [Christ] had selected people who were close to God. Satan had just a few of them. And he started crying, Satan, he said: 'You have them all.' And He said: 'In the end, all of them will be yours. And I will have just a few of them, just like you do right now.' So this is it. People do not believe. They used to believe in God, used to pray and feel some fear...

Even though this story deals with the end of times, it also contains a dualistic motif describing how God and Satan discuss the redistribution of power over people at the beginning and at the end of times.

Another etiology that refers simultaneously to the beginning of times and to the last times was recorded in Central Polesye, Zhitkovichsky District, Gomel Region, in 2004:

Sechyk u nas byŭ dzed, Yon chytaŭ i gavaryŭ, shto buduts' itsí brat na brata, syn na bats'ka, bats'ka na syna, budze s'vet uves' abtsyanuty pravadamí... Shto zhaleznyya ptushkí lyatatsímuts'... Í shche yon kazaŭ, shto yak Bog pus'tsíŭ na zemlyu yangelaŭ, da skazaŭ, shto dolzhen s'vet sushchestvavats' tysyachu vasemsot god. A yangoly spus'tsílísa na etu zemlyu da rashylí ŭdvoíkh: 'A chago-to tam Bog skazaŭ tysyacha vasemsot? Davay okruglim, nyakhay budze dz've tysyachy.' Nu, prylyatselí nazad i kazhuts': 'Ot, tak i tak my zrobílí. Pravil'no my zrobíli tsí nepravíl'no?' A Von kazhe: 'Znayetse, shto? Tysyachu vasemsot god lyudzí buduts' poBozhomu. A getyya dzvestse god buduts' zhyts' - khto yak prydumaye.' Mozha yano tak i ye? Khto yak khocha, tak i zhyve. A pos'le dvukh tysyach, kazaŭ, i s'veta isnavats' ne budze, uso budze garets', budze kanets s'vetu. A kali yon budze? Uso ídze k yetamu. ${ }^{30}$ (Tradytsyynaya 2013: 575) 
Our grandfather's nickname was Sechik. He would read and say that brother would be incited against brother, son against father, father against son, and the whole world would be covered with wires... Iron birds would be flying... He would also say that God had let the angels descend on the earth and said that the world would exist 1,800 years. The angels came down to the earth and decided: 'Why did God say 1,800 years? Let us round it up and make it 2,000.' Then they returned to God and told him: 'This is what we did. Was it right or wrong?' And He said: 'You know what? People will be living according to God's laws for 1,800 years. And they will live the remaining 200 years any way they like.' Maybe this is it? Today we are living any way we like. He said that after two thousand years, there will be nothing, everything will be burning, the end of the world will come. When will it happen? I think we're heading that way.

In this narrative, the prophecies about the last times before the end of the world, which are common for the Belarusian vernacular religious stories, transgress into a single (for Belarus) etiology about the primary purpose and change of times. The recordings of such etiologies also exist, for example, among the Russians and the Komi. In the Russian version, God's messenger brings the books written for people, which say how long the world will exist. The messenger adds 200 years more, during which people will be living in great depravity, and that will be the time before the end of the world. ${ }^{31}$ In the Komi legend, extra years are added neither by the angels nor by God's messenger, but by Solomon, who chained Satan in hell until the end of times, and, on his way to Mount Zion, changed the inscription on the stone post put up by Christ, saying that "people will live for a thousand years, and then changes will come". Solomon added 1,000 years, not $200^{32}$ (Limerov 2012: 35-36). A full text of the Komi legend corresponds to the international fairy tale plot ATU 803 about Solomon chaining Satan in hell with a trick, using the chain that will keep him there till the end of times. The Belarusians, Russians, and Ukrainians have a similar fairy tale plot about Satan's chain (Sravnitel'nyy 803), but without the legendary fragment concerning the change of times. Perhaps the source for this fragment is an international fairy tale plot about Solomon, from which the Belarusians and Russians singled out an independent legendary plot that helped them to justify the end of the world. 


\section{CREATION OF FIRE}

A text about the origins of fire, i.e., one of the main elements of the world, was recorded in 2003. It seems very laconic and quite ambiguous:

Ya chula davno ge, sho to ogon'- yogo ne mozhno bits'. Bo von s choloveka. 'A chamu ne mozhna?' - 'A ya vedayu? Ogon', kaa, s choloveka.'33 (Tradytsyynaya 2009: 438)

I heard it a long time ago, about fire, that you shouldn't beat it. Because it comes from Man. 'Why shouldn't you do that?' - 'I don't know. They said fire originated from Man.'

There are counterparts to that one neither in contemporary recordings made in Belarus nor in the recordings made by collectors in the nineteenth and twentieth centuries. Concerning the origins of fire, at the end of the nineteenth and the first half of the twentieth centuries, recordings were made in Belarus, according to which fire originates from perun (lightning) that was used by God when he wanted to kill the devil, who seduced Adam and Eve in Paradise (Federowski 1897: 239; Pietkiewicz 1938: 29-30); God taught Man to make fire, showing to him how to rub pieces of wood against each other. The devil saw how to make fire, which had become "as huge as a forest" and scorched him, and made it himself. The devil took fire into hell "to torture sinful souls with fire" (Federowski 1897: 239; Serzhputovskiy 1930: 25-26). The Ukrainians from Transcarpathia have a similar version of the story. However, they believe that fire was invented by the angels that fell from grace and headed to hell. They invented fire in hell to torture sinful souls (Sen'ko 1993: 21-22). Christ and Peter stole fire from the devil, who had laid the fire near the road, to bring it to people. Similar etiological versions exist among the Russians and the Polish (in Polish Yule-songs).

The Slavs do not know tales about the genesis of fire from a human, although the European geography of the plot describing the anthropomorphic embodiment of fire and the God of Fire is quite extensive (Baltic-Scandinavian, Balkan, South-European) (Kerbelite 2001: 252; Berezkin \& Duvakin: D1). Additionally, the Finns have a legend about fire being given birth to by a woman, who had carried to term but was only able to give birth in the sea and could not touch the newborn (Berezkin \& Duvakin: D3).

As for a ban on beating fire, it exists among the Ukrainians living in Sloboda Ukraine. In particular, it was forbidden to spit on fire, since in the afterlife, any person who spit on fire would be licking a burning-hot pan (Chubinskiy 1995: 49). 


\section{LEGENDS ABOUT THE CREATION OF PEOPLE}

While all of the original cosmogonic etiologies were non-biblical, all of the rare anthropogenic etiologies that are under consideration in this article are folk biblical. The selection provided here makes up part of the motifs in legends about the creation of people.

The most frequent motifs of anthropogenic legends are folk biblical plots about the creation of the first people (Adam from the dust of the ground and Eve from Adam's rib), the differences between the sexes (after the fall from grace, people lost their "fingernail" bodies, and sex differences between men and women came into being). This also includes the etiologies about why children cannot walk from their birth and why people do not know the time of their death, which are widespread in Belarus.

As for rare, single recordings of etiologies pertaining to the origins of people, the following has been recorded in the last 20 years: about how sexual intercourse between Adam and Eve happened (two versions); why women do not give birth through the top of their heads; why men have hair on their bodies.

Íshlí yany ŭdvaíkh - staíts' mora. Cheraz mora lyazhyts' kladka. Yany na etu kladku ŭzyyshlí. A eta kladka zasygalasya. Eta Yeva sela, a ety staíts' lya yaye Adam. Í zrabílasya: mora nyama, a mos'tsík taki astaŭsya. Yany na kladku stalí, uzho i níma mora, bylo mora, a zrabíŭsya mos'tsík. Í abkhvatsíla îkh noch. Í shto - adnamu legtsí tol'kí, drugomu níma dze legtsí. Í vot aní tut sablaz'nílí drug druga. ${ }^{34}$ (Tradytsyynaya 2013: 534-535)

They were walking together - and then there was the sea right in front of them. There was a boardwalk across the sea. They stepped on the boardwalk. But it wobbled. Eve sat down, and Adam stood right beside her. And this is what happened: there was no sea any longer, but just the boardwalk. They were standing on the boardwalk, there was no sea, just the bridge. And then the night embraced them. And if one of them would lie down, another one would have nowhere to lie. And this is when they seduced each other.

The full text is an extensive narrative with the contamination of many motives: the creation of Adam and Eve, their skin as if covered by fingernails before the fall from grace, the fall from grace of the first people, turning a man into a stork, origins of hair on human bodies, etc. When specifying details, the informant provides the following version of the text: 
Íshlí cheraz rechku tsí cheraz mora í payavílasya kladachka. Yany íshlí i payavilasya noch. Yany z nochy. Noch nastupíla-kuda itsí? Í payavíŭsya mos'tsík. A ety mos'tsík tol'kí adnamu chalaveku legtsí. Log Adam, nyama dze Yeve. Yeva lyazha, Adamu nyama dze. Vot yany ŭ eta ŭremya i sagrashyli Bogu. Vot tak. (Tradytsyynaya 2013: 534-535)

They were walking across the river or across the sea, and they saw a boardwalk. They kept on walking, and then the night fell. They walked into the night. The night came - where to go? And then there was a bridge. But only one person could lie on that bridge. If Adam lies down, there will be no place for Eve. If Eve lies down, there will be no place for Adam. This is when they sinned before God. This is how it happened.

In this interpretation, the etiology of the sexual relationship between men and women is singular, although the perception of the fall from grace of the first people as having sexual relations is typical of many Slavic (Belarusian, Ukrainian, Russian, Polish, Bulgarian, etc.) traditions. In the text cited above, an original element is the motif of crossing the sea over the bridge, which was obviously borrowed from magic fairy tales, while at the same time it is perfectly logical and justified: the transition from the "Paradise" state into the earthly life is depicted via mythologically rich images of the sea (water barrier), and a bridge (crossing the barrier, connecting the worlds).

As for the next text about the origin of sexual relations, in the Belarusian version it is clearly incomplete and very unclear.

'A dzetsí ŭ Adama í Yevy bylî?' - 'Nu, konechno, poyavílísa. To zh vony Bogu i nagreshylí. Sho vony nekogo platochka, chí sho, s'tsírali... A sushyts'-to ne bulo dze. Nu ya ne pomnyu, sushyli yak. Odam... Uzhe vony sogreshyli vdvokh.' - 'A shto zh za platochak yany stsírali?' - 'Nu nosovy platochok. Kogda vony sogreshyli, to vono i poshlo. ${ }^{35}$ (Tradytsyynaya 2009: 375-376)

'Did Adam and Eve have children?' - 'Yes, of course they did. They sinned before God. They said they were washing a kerchief or something... And there was nowhere to dry it. I don't remember how they were drying it. Adam... They sinned together.' - 'What kind of kerchief were they washing?' - 'A handkerchief. They sinned, and then it all started.'

The motif of a kerchief washed and dried by Adam and Eve in relation with the fall from grace is clarified in comparison with the Polish narratives about the fall from grace, particularly with the following text: ${ }^{36}$

When Adam and Eve lived on the Earth, there were no trees. They washed a handkerchief and did not know where to dry it. Eve saw Adam's branch. 
She put the handkerchief on his branch, and Adam bent down. He saw Eve's hole and inserted his branch into her hole, and there was a bull behind Adam who hit him all of a sudden, almost breaking Adam's branch. (Zowczak 2013: 96)

In another version of the Polish legend, Adam and Eve went down to the river and washed a handkerchief. There was nowhere to dry it, and Eve saw Adam's branch. She put the handkerchief on his branch. Adam grew tired of holding the handkerchief and snuggled against Eve. At this very moment, the devil disguised as a bull butted Adam at his back - "this is how the world started" (ibid.). According to the comment made by Zowczak, the Polish texts differ in the fact that in the first case, sexual relations start by themselves and at the will of God. In the second case, sexual intercourse happens as a result of the act of the devil disguised as a bull, who is literally pushing Adam into intercourse (ibid.).

Since the Belarusian text (more precisely, a fragment of it) was recorded in the Brest Oblast, which had been under the jurisdiction of Poland until 1939, ${ }^{37}$ in this case we can assume a direct borrowing from the local Polish tradition. Along all other folk biblical motifs of the Belarusian-Polish frontier, this particular plot is absent from the Belarusian territory in contemporary existence, while many others are widespread until now (about the miraculous growth of wheat, the spider who saved the Holy Family, the reasons why an aspen tree shakes, a prudent bandit, turning Christ into wheat, etc.) (see Tradytsyynaya 2009: 388-394; Boganeva 2010: 79-89).

A rare folk biblical anthropogenic legend is also the etiology explaining why women do not give birth through the top of their heads.

Eto bylo tak. Byla, vobshcham, Yeva byaremenna, vot. Yey nada bylo razhats'. Í Bog skazaŭ tak, shto yes'li ty, Adam, z'yasí yablako... Yana skora razhala, yana ne razhala tudeyu, kudeyu zaraz razhayuts'. Eto maya s'vyakrukha raskazvala. Yana tsem'yam razhala, tut, dze ŭ nas tsem'ya, Yeva razhala yeto dzitso. Í, znachyts', nya nada bylo yes'tsi eto yablyko. A yon yeto yablyko z'yeŭ, í ŭ yago yeta kostachka. A zhanchyny ne razhayuts' dzyatsey praz tsemya. ${ }^{38}$ (Tradytsyynaya 2013: 533)

This is how it happened. Right, so, Eve was pregnant. It was time for her to give birth. And God said that if you, Adam, eat an apple... Soon she started giving birth, but she was giving birth through a different place than the one women give birth through today. My mother-in-law told me this. She was giving birth through the top of her head, this is how Eve gave birth to her child. It means that Adam should not have eaten that apple. But he did, and now he has an apple in his throat. And women do not give birth to children through the top of their heads. 
I am not going to dwell upon the motif of miraculous birth through the leg, the top of the head, etc., because this topic is too extensive and is partially dealt with in the Analytic Catalogue by Yuri Berezkin and Evgeniy Duvakin (F2). In Europe, this motif comes across repeatedly in the legends of ancient Greece, particularly in the legends about the birth of Dionysus - through Zeus's hip, and the birth of Athena - from Zeus's head; in Icelandic legends called the Prose Edda we observe the entire generation of frost giants that are born from the leg of the giant Ymir: "They say that once after falling asleep he broke into perspiration, and he birthed a male and a female from the pits of his arms. And his legs together begat a son. And this is where all of his offspring, the frost giants, came from" (Sturluson 1970: 11).

In Slavic legends a miraculous birth is usually ascribed not to Eve, but to Mary, the mother of Jesus. The same motif exists in the Belarusian tradition, too.

Vyn zhe Syn Bozhy. Yogo zh narodzíla Matsí... Prostaya dzevka. Vona i skazala... Pryyshli do Yeye, toye Dzevochki, í govorats': 'Ot, Ty bíremenna.' A Vona kaa: 'Kak ya budu bíremenna, yak ya muzha ne meyu?' A vony skazalí: 'Ty ot Dukha S'vyatogo budzesh, da, í vrodzish Bozhogo Sína. Í nazovuts' Ísus Khrystos.' I ot tak vono í bulo. Í Vona zh ne rozhala gek by mí rozhayem. Vona proz bok. ... Yangol sputsívsa s nebes í skazav. A v Yeyí buv zheníkh Íosíf. Vyn... Yangol spustsívsa i skazav na Yeyí, shcho Ty blaslovlena ot Dukha S'vyatogo. 'Tak Yana praz bok naradzíla?' - 'Da, da. ... Vona ne rozhala tak, gek by mí.'39 (Boganeva 2010: 64)

He is a son of God. Born from a simple girl... She said... They came to visit that girl and told her: 'You are pregnant!' And she said: 'How can I be pregnant if I don't have a husband?' And they said: 'You are pregnant from the Holy Spirit, and you will give birth to God's Son. And he will be named Jesus Christ.' And this is indeed what happened. And she did not give birth the way we do. But through the side. ... An angel came from the skies and told her that she was blessed by the Holy Spirit. 'So did she give birth through the side?' - 'Yeah, yeah. ... She didn't give birth the way we do!'

The motive of the birth of Christ from the head of Mary, the mother of Jesus, also pops up in the legends of the Ukrainians living in Podolia (Chubinskiy 1995: 160). In the legends of the Hutsuls, Christ is born from the cross which "jumped out of the water" and hit the armpit of the Mother of God (Belova 2004: 313).

The etiology about why men have hair on their bodies is individual among the Belarusians. 
A toy yashche Adam. Yano í napos'le bylo. Yany íduts'. Staíts' zabor, plot. I za plotam voŭk avechkí kradze. Nu yak zha yon? Khatseŭ zalez'tsí í ne zaleze - vysoka. Khatseŭ pad níz - ne mozhna. Dyk u takuyu shchylínu papaŭ i ŭlez. Ulez - dyk u nekatorykh vo tut valasy rastuts' [pakazvaye na grudzí] í tut rastuts' [pakazvaye nizhey poyasa]. Vot yon pralez, tut i zrabílasya takoye tsela ŭ yago. Praŭda tsí ne... ... Yon ulez cheraz ety zabor, shtob adbaraníts' ad voŭka, avets spas'tsí. Yamu tak nada, ad Boga dadzena. Vot u nekatorykh... tut, dze zachapíŭsya grudz'mí, tut i zastalisya valasy, vot i yos' u nekatorykh mushchyn, a tut astalisya naŭsegda. 'Yon byŭ uves' valasaty?' - 'Yon ne byŭ valasaty, bylo takoye tsela, yak kípets'. '40 (Tradytsyynaya 2013: 534-535)

And there was Adam. It happened after that. They were walking, and then they saw a fence. And a wolf was stealing sheep behind that fence. And what about Adam? He wanted to climb the fence, but he couldn't, because it was too high. He wanted to crawl under the fence, but he couldn't do that either. Then he managed to squeeze through a gap in the fence. He squeezed through it, and then he had hair on his body, here [points at the chest] and here [points at the area below the belt]. He squeezed through, and then he had a body like that. I don't know if it is true or not... ... He squeezed through that fence to save the sheep, to protect them from the wolf. And God gave him hair on his body. Yeah, and some men... Hair started growing right where his body clung against the fence, for example, on his breast, and now some men have hair on those parts of their bodies, for good. 'Was he hairy all over his body?' - 'He was not hairy, but his body was like boiling water.'

The origin of hair on the human body is quite a rare motif in the folk Bibles of the Slavic and Baltic peoples. More often, we can come across the opposite motive in folk Bibles: at the beginning of times, first people were hairy all over their bodies, but then their bodies became smooth.

Adam í Yeva... Yak payaŭlyaŭsya yashche tol'kí bely s'vet. Íz Adamavaga rebra vyrezali, í yak-to yany tamats'ka sheptali... Tol'ka my iz Adamavaga rebra. Lyudzí pervyya bylí. Í payavíŭsya ŭ îkh dzítsonak. Yany bylí takíya zaroslyya, a tady ŭzho ... stali narazhdatstsa lyudzi kharoshyya. Payavíŭsya s'vet, i stalí narazhdatstsa kharoshyya. Achys'tsílasya íkhnaye tsela, i payavilisya lyudzi kharoshyya. ${ }^{41}$

Adam and Eve... How did the wide world come into existence? Cut from Adam's rib, whispering something... We come from Adam's rib. There were 
the first people. And they had a baby. Their bodies were hairy all over ..., and good people were born. The wide world emerged, and good people were born. Their bodies became clean, and good people came into being.

The motif of the initial hairiness (together with the motive of "fingernail"-type bodies) of people also occurs in Polish (Zowczak 2013: 97) and Bulgarian (Badalanova 1997-1998: 14) traditions, among the Ukrainians living in Transcarpathia and the Old Believers from Kirov Oblast (Belova 2004: 241).

As for the emergence of hair on human bodies, Vladimir Gnatyuk (Galicia, Western Ukraine) reveals the following etiology. Eve was not afraid of Adam at all, and Adam started asking God to make Eve scared of him, perhaps just a little. God told him to go into the river and wash his face, then he would have a beard and moustache. This is what Adam did, and then he put his hand between his legs, and had hair there, too. Eve was not scared that much, and she decided to do the same thing as Adam to make Adam scared of her. But when she entered the river, a bee stung her between her legs. Eve seized her perineum with a wet hand, and hair appeared there. Eve did not touch her body with wet hands anymore, because she was afraid of the bee (Gnatyuk 1902: 23). A similar plot exists in the Lithuanian tradition: Adam washed his head, chin, and the area around his mouth with spring water, and hair started growing there. Eve washed her head and flicked the flies away with wet hands. The parts of her body that she touched became covered with hair (Kerbelite 2001: 53).

In Belarus, there is an original version of the etiology with the motif of squeezing through a gap in the fence. As Volodina has pointed out, "in the Gomel version of the legend, hair started growing on the chest and the genitals of a man after he was trying to squeeze through a gap in the fence in order to chase a wolf away from the sheep" (Volodina 2013). A desire to squeeze through the fence is perfectly clear within the framework of the sound peasant pragmatics. However, the idea of the fence itself and squeezing through it are deeply mythological in the actional language of the culture, where they symbolise a successful crossing of the inter-universe border.

\section{CONCLUSIONS}

The existence and distribution of etiological plots (non-biblical about the origins of the universe and folk biblical about the genesis of human beings), without any doubt, reflect a specific level and character of folk religiousness, i.e., the actualisation of religious experience in culture (see Panchenko 1998: 8). In the vast majority of cases contemporary rural informants of the older generation 
belong both to the culture of the oral tradition, and the written, "technical" one (see Chistov 2005: 26-43 about the fundamental differences between those culture types). Among the generation born in the $1920 \mathrm{~s}$, there are still some informants who did not have any school education at all, but the majority of them have primary education (four years). The vast majority of the representatives of the generation born in the 1930s-40s have either primary or secondary education (7-10 years). This means that they can acquire knowledge about the origins of the universe and human beings both from the oral local tradition and from written sources (including radio, TV, mass media, etc.). This is why there are contaminations of traditional oral perceptions with the prevailing scientific worldview, resulting in "the Earth is round, it goes round, and lies on the back of the turtle".

As for the folk Bible, even though today the Bible is generally available, and the informants are able to read it, the proportion of people reading it (especially the Old Testament) among rural bearers of the Orthodox and Catholic tradition is relatively small. At the same time, at the contemporary stage, they find their way around biblical events quite easily, particularly in Western Belarus where the tradition of religious upbringing in families has virtually not been interrupted, and informants often recall older members in their families reading something to them from the Bible (see Boganeva 2015: 285-303). This is why in a vast majority of recordings about the creation of the world and people informants retell the first chapters of the Book of Genesis, in some cases quite close to the original. Dualistic motifs are rarely present in contemporary recordings.

It is as a result of all of the factors listed above as well as due to universal globalisation processes, migration, the distribution of technical communication means, etc., that the field of rural traditional culture in general and of etiological prose in particular is narrowing in Belarus year after year. Nevertheless, even in current decades the corpus of the recordings of facts and artefacts of the rural oral tradition is replenished and expanded, including some rare facts that are deeply enrooted in the tradition of etiologies.

\section{ACKNOWLEDGEMENTS}

The article was written as part of a project financed by the Foreign Ministry of Estonia through the Developmental Cooperation Programme (66-2015-A). 


\section{NOTES}

1 The term "etiological legends" in the sense specified above is used all over Europe-

2 As far as tradition bearers are concerned, these biblical texts are quite often related to the Bible in particular. For example, Adam and Eve are turned into storks as a punishment for their fall from grace (Boganeva 2010: 39), ears of grain also stop being filled with grain from the bottom to the top as a result of the fall from grace (ibid.: 18, 26), and this is also the reason why a woman is always much busier than a man (ibid.: 28-29).

3 Following the results of this work, which lasted from 1995 until 2013, 10 volumes within the series The Traditional Artistic Culture of the Byelorussians, mentioned above, were published, covering all the 6 historical and ethnographical regions of Belarus.

4 Elena Boganeva authored and compiled these chapters.

5 According to its administrative division, there are 6 regions (oblasts) and 118 districts in Belarus. In the course of 20 years, the author of this article conducted field research in the 64 districts of all of the regions of Belarus (10-12 districts per region, 6-8 villages studied in each district). In addition to the team mentioned above, which was doing field research in 1995-2013, regional studies were also carried out by regional universities (within the framework of student practice at philology departments), and also the staff of the Academy of Sciences on separate topics. Talking about rare and individual etiologies, I also considered archives (academic and university ones) and publications on relevant topics.

6 In her collection, Belova studies the Eastern Slavic etiological legends of the folk Bible.

7 The term folk Bible itself has not appeared in recent decades parallel to the writings mentioned above, but was used by Russian researchers of the Apocrypha at the end of the nineteenth century, for example, in the work by Mochul'skiy, Traces of the Folk Bible in Slavic and Old Russian Writing Systems (Mochul'skiy 1893), but it became obsolete for almost a century.

8 For more detailed information about the history of the terminology and evolution of biblical narratives as a subject of research see Boganeva 2016.

9 References can also be given only to a written source or to the oral tradition.

${ }^{10}$ From this point onward, extracts from expedition experience of the author of the article are cited.

${ }^{11}$ Recorded in 2012 by N. Antropov, E. Boganeva, and T. Volodina in the village of Kanichi, Kostyukovichsky District, Mogilev Region, from Raisa Moiseenko, born in 1936.

${ }^{12}$ Recorded in 2007 by E. Boganeva in the village of Dukora, Pukhovichi District, Minsk Region, from Sofia Mazovka, born in 1927. If no collector is further indicated, the records are those collected by the author of this article. 
${ }^{13}$ Admittedly, at present many rural informants, especially those born in the 1940s-1950s, who have secondary or vocational secondary education, regard etiological legends as fairy tales.

${ }^{14}$ Recorded in 2002, in the village of Voistam, Smorgon District, Grodno Region, from Anelia Petukh, born in 1919.

${ }^{15}$ Recorded in 2006, in the village of Kamenka, Uzden District, Minsk Region, from Larisa Guleichik, born in 1929.

${ }^{16}$ Recorded in 2012 by T. Volodina in the village of Pogost, Zhitkovichsky District, Gomel Region, from Ivan Zokhno, born in 1929.

${ }^{17}$ Recorded in 2011 in the village of Byvalki, Loevsky District, Gomel Region, from Maria Davydovskaya, born in 1933.

${ }^{18}$ Recorded in 2007 by I. Mazyuk in the village of Ulka Telekhanovskaya, Ivatsevichi District, Brest Region, from Lydia Kuprianchik, born in 1923.

${ }^{19}$ Recorded in 1975 by T. Sudnik in the village of Veliky Bor, Khoynitsky District, Gomel Region.

${ }^{20}$ It occurs in different parts of the world consistently through a combination of a number of common attributes. Typological relations are not limited by some temporal, territorial or other external factors and are determined by the resemblance between the historical development of peoples, and their social, cultural, household, and psychological differences (see Putilov 1976: 9).

${ }^{21}$ Recorded in 1998 by E. Boganeva and T. Varfolomeyeva in the village of Andreevskaya Sloboda, Shumilinsky District, Vitebsk Region, from Anna Kozlova, born in 1901.

${ }^{22}$ That being the case, the proximity to the myths of these distant countries is only in terms of the topic, but not in terms of the plot of meaning.

${ }^{23}$ In ancient Indian mythology, Purusha is the first human, from whom the elements of space emerged. Purusha is sacrificed by means of dismembering his body into constituent parts, from which the elements of social and cosmic organisation emerge (see Toporov 1992: 351).

${ }^{24}$ Golubinaia Kniga (Stone Book, Depth Book) is a collection of spiritual folk poems from the end of the fifteenth and the beginning of the sixteenth centuries. Questions and answers provide information about the origins of the world, people, social strata, geographical and scientific data, etc. "The basis of the poem from The Book of the Pigeon is made up of the oldest cosmogenic folktales that the great Russian people have in common with other Indo-European peoples" (Mochul'skiy 1887: 4).

${ }^{25}$ This apocryphal story was well known in the traditional culture of Eastern-Slavic peoples. In particular, it greatly influenced Belarusian dualistic legends, in which the God and the devil take part in the creation of living beings; for example, a legend about the creation of a human and a dog (Dobrovol'skiy 1891: 230-231).

${ }^{26}$ Unlike the legends describing common regularities of the world, lore tells us about the peculiarities and history of specific areas, their toponymy, hydronymy, etc. 
${ }^{27}$ Translator's note: all of those names refer to the names of body parts.

${ }^{28}$ Recorded by E. Boganeva and T. Varfolomeyeva in 2006 in the village of Rassvetnoye (formerly Tsytskovichi), Kletsk District, Minsk Region, from Konstantin Shalokha, born in 1935, and Alexandra Shalokha, born in 1930.

${ }^{29}$ Recorded in 2012 by E. Boganeva and T. Volodina in the village of White Dubrova, Kostyukovichsky District, Mogilev Region, from Sofia Efimenko, born in 1935.

${ }^{30}$ Recorded in 2004 by E. Boganeva and T. Varfolomeyeva in the village of Veresnitsa, Zhitkovichsky District, Gomel Region, from Olga Mozhak, born in 1948.

${ }^{31}$ Recording from the archives of the National Literary Museum, made in the village of Yarki, Yeniseysk Governorate of Pinchugskiy District (Belova \& Kabakova 2014: 43-44; 333-334).

${ }^{32}$ Recorded in 2000 by P. Limerov in the village of Pozheg, Ust-Kolomsky District, Komi Republic, from E. Shakhova, born in 1928.

${ }^{33}$ Recorded by E. Boganeva and T. Varfolomeyeva in 2003 in the village of Sitnica, Luninets District, Brest Region, from Ulyana Yarmolich, born in 1913.

${ }^{34}$ Recorded by T. Volodina in 2012 in the village of Smykovichi, Oktyabrsky District, Gomel Region, from Evgenia Lukashevich, born in 1929.

${ }^{35}$ Recorded by E. Boganeva and T. Volodina in 2007 in the village of Ulka-2, Luninets District, Brest Region, from E. Sots, born in 1938, T. Vechorka, born in 1935, and L. Germanovich, born in 1938.

${ }^{36}$ Author's translation.

${ }^{37}$ In accordance with the Treaty of Riga (1921), after the Soviet-Polish war (1919-1921), the western part of contemporary Belarus formed a part of Poland until the Soviet invasion of Poland (September 1939). Officially, Western Belarus was incorporated as part of the USSR on 2 November 1939.

${ }^{38}$ Recorded in 2005 in the village of Novaya Rudnya, Yelsk District, Gomel Region, from Nadezhda Mazurenko, born in 1937.

${ }^{39}$ Recorded by E. Boganeva and T. Volodina in 2007 in the village of Ulka-1, Luninets District, Brest Region, from Olga Stasyuk, born in 1929, and Maria Lobko, born in 1933.

${ }^{40}$ Recorded by T. Volodina in 2012 in the village of Smykovichi, Oktyabrsky District, Gomel Region, from Evgenia Lukashevich, born in 1929.

${ }^{41}$ Recorded by T. Volodina in 2012 in the town of Khotimsk, Mogilev Region, from Elizaveta Shunkinay, born in 1927. 


\section{REFERENCES}

Albert-Llorca, Marlène 1991. L'ordre des choses. Les Récits d'origine des animaux et des plantes en Europe. Paris: Éds. du CTHS.

Badalanova, Florentina 1994. BIBLIA FOLKLORICA (Folklorna konfesionalna konventsiya na balgarite v Besarabiya i Tavriya). [Biblia Folklorica (Folklore and Confessional Convention of the Bulgarians Living in Bessarabia and Tavria).] Balgarski folklor, Vol. 1, pp. 5-21.

Badalanova, Florentina 1997-1998. Ekskursy v slavyanskuyu fol'klornuyu Bibliyu: zhertva Kaina (Fol'lornyye i literaturnyye versii odnogo bibleyskogo syuzheta). [Excursions into the Slavonic Folklore Bible: The Sacrifice of Cain (Folklore and Literary Versions of One Biblical Story).] AION. SLAVISTICA: Annali dell'Istituto universitario Orientale di Napoli, No. 5, pp. 11-32.

Badalanova Geller, Florentina 2008. The Bible in the Making: Slavonic Myths of Creation. In: M. Geller \& M. Schipper (eds.) Imagining Greation. Leiden \& Boston: Brill, pp. 161-364.

Badalanova Geller, Florentina 2011. The Sea of Tiberias: Between Apocryphal Literature and Oral Tradition. In: L. DiTomasso \& Ch. Böttrich (eds.) The Old Testament Apocrypha in the Slavonic Tradition: Continuity and Diversity. Texts and Studies in Ancient Judaism 140. Tübingen: Mohr Siebeck, pp. 13-158.

Belova, Ol'ga (comp.) 2004. "Narodnaia Bibliia": Vostochnoslavianskie etiologicheskie legendy. [Folk Bible: South-Slavic Etiological Legends.] Chief editor Vladimir Petrukhin. Moscow: Indrik. Available at http://inslav.ru/images/stories/pdf/2004_ Narodnaja_Biblija.pdf, last accessed on 14 June 2018.

Belova, Ol'ga \& Kabakova, Galina (comps.) 2014. U istokov mira: Russkie etiologicheskie skazki $i$ legendy. [At the Origins of the World: Russian Etiological Tales and Legends.] Moscow: FORUM \& NEOLIT. Available at http://inslav.ru/sites/default/ files/editions/2014_u_istokov_mira.pdf, last accessed on 14 June 2018.

Berezkin, Yuriy 2005. Mir cherepakhi: ot detskikh rasskazov do kosmogonii (v sviazi s oberegom iz severoamerikanskoi kollektsii MAE). [The World of the Turtle: From Children's Stories to Cosmogonies (in Connection with the Amulet from the North American Collection of MAE).] In: Y. Berezkin (chief ed.) Sbornik MAE, Vol. 50. Aborigeny Ameriki: predmety i predstavleniia: [Sbornik statei]. St. Petersburg: MAE RAN, pp. 251-279. Available at http://www.kunstkamera. ru/files/lib/5-88431-119-2/5-88431-119-2_05.pdf, last accessed on 14 June 2018.

Berezkin, Yuriy \& Duvakin, Evgeniy. Tematicheskaia klassifikatsiia i raspredelenie fol'klorno-mifologicheskikh motivov po arealam: Analiticheskii katalog. [Thematic Classification and Distribution of Folklore-Mythological Motifs by Area: Analytical Catalogue.] Electronic resource. Available at http://ruthenia.ru/folklore/berezkin/, last accessed on 12 June 2018.

Boganeva, Alena 1998. Apytal'ník pa zboru materyyalaŭ pa narodnay proze. [Questionnaire for the Collection of Materials on Folk Prose.] Minsk: BelÍPK.

Boganeva, Alena 2010. Belaruskaya "narodnaya Bíblíya” ŭ suchasnykh zapísakh: Ustupny artykul, ukladanne i kamentaryí. [Belarusian Folk Bible in Modern Records: Introductory Article, Compilation and Comments.] Minsk: Belaruskí dzyarzhaŭny uníversítet kul'tury í mastatstvaŭ. 
Boganeva, Elena 2008a. Narodnaya proza. [Folk Prose.] In: T. Varfolomeyeva (ed.) Dasledavanne lakal'nykh kul'tur Belarusí: Pragramy pa zbory fal'klorna-etnagrafichnykh materyyalaŭ. [Research of Local Cultures of Belarus: Programmes for Collecting Folklore and Ethnographic Materials.] Minsk: BDUKM, pp. 113-140.

Boganeva, Elena 2008b. Narodnaye pravaslaŭe. [People's Orthodoxy.] In: T. Varfolomeyeva (ed.) Dasledavanne lakal'nykh kul'tur Belarusí: Pragramy pa zbory fal'klorna-etnagrafichnykh materyyalaŭ. [Research of Local Cultures of Belarus: Programmes for Collecting Folklore and Ethnographic Materials.] Minsk: BDUKM, pp. 153-166.

Boganeva, Elena 2008c. Narodnaya Bíblíya. [The Folk Bible.] In: T. Varfolomeyeva (ed.) Dasledavanne lakal'nykh kul'tur Belarusí: Pragramy pa zbory fal'klorna-etnagrafichnykh materyyalaŭ. [Research of Local Cultures of Belarus: Programmes for Collecting Folklore and Ethnographic Materials.] Minsk: BDUKM, pp. 167-178.

Boganeva, Elena 2012. Belaruskíya legendy pra charapakhu ŭ kantekstse susvetnykh kasmaganíchnykh mífaŭ. [Belarusian Legends about the Turtle in the Context of Cosmogonic Myths.] In: M. Mazheyka (ed.) Aŭtentychny fal'klor: prablemy vyvuchennya, zakhavannya, peraymannya. Zborník navukovykh prats udzel'níkaŭ VÍ Mízhnarodnay navukova-praktychnay kanferentsyí (Mínsk, 27-29 krasavíka 2012 g.). Minsk: Belaruskí dzyarzhaŭny uníversítet kul'tury í mastatstvaŭ, pp. 104-107.

Boganeva, Elena 2015. Tsennostnye predstavleniia belorusov o vere: belorusskaia "narodnaia Bibliia" i kommentarii k nei nositelei traditsii. [Axiological Representations of Belarusians about Religion: "The Folk Bible" and Comments to It of the Tradition Maintainers.] In: S. M. Tolstaya (chief ed.) Kategoriia otsenki $i$ sistema tsennostei v iazyke i kul'ture. Moscow: Indrik, pp. 285-303.

Boganeva, Elena 2016. Bielaruskaja "narodnaja Biblija": historyja, uplyvy, vidažanravy sklad. [Belarusian "Folk Bible": History, Influences, Genre Structure.] In: A. Lakotka (sc. ed.) Narysy historyi kultury Bielarusi. U 4 t. T. 3. Kultura siala XIV - pač. XX st. kn.2. Duchoŭnaja kultura. Minsk: Bielaruskaja navuka, pp. 594-623.

Chistov, Kirill 2005. Spetsifika fol'klora v svete teorii informatsii. [Specificity of Folklore in the Light of Information Theory.] In: K. Chistov. Fol'klor. Tekst. Traditsiia: [sbornik statei]. Moscow: OGI, pp. 26-43.

Chubinskiy, Pavel 1995. Mudríst'víkív. U 2-kh kn. Ukraïns'ke narodroznavstvo u tvorchíy spadshchini Pavla Chubins'kogo. [Wisdom of the Centuries. In 2 Volumes. Ukrainian Ethnology and Creative Heritage of Paul Chubinsky.] Vol. 1. Kiev: Mistetstvo.

Dobrovol'skiy, Vladimir 1891. Smolenskii etnograficheskii sbornik. [Smolensk Ethnographic Collection.] Vol. I. St. Petersburg: Tipografiya Ye. Yevdokimova.

Federowski, Mihal 1897. Wiara, wierzenia i przesqdy ludu z okolic Wotkowyska, Stonima, Lidy i Sokótki. Lud biatoruski na Rusi Litewskiej: Materiały do etnografii stowiańskiej zgromadzone $w$ latach 1877-1905: $w 8 t$. [Faith, Beliefs and Superstitions of the People from around Wołkowyska, Słonima, Lida and Sokółka. Belarussian People in Lithuanian Rus: Materials for Slavic Ethnography Collected in 1877-1905: In 8 Volumes.] Vol. 1. Kraków: Wydawnictwo Komisji Antropologicznej Akademii Umiejętności. 
Gnatyuk, Vladimir 1902. Galits'ko-rus'ki narodní legendi. [Galician-Russian Folklore Legends.] T. 1. Yetnografíchniy zbírnik, T. XII, L’vov: Etnografichna komisíya navukovogo tovaristva ímeni Shevchenka.

Grynblat, Míkhaíl \& Gurskiy, Anton (comps.) 1983. Legendy i padanní. [Legends and Stories.] Edited by A. Fiadosík. Minsk: Navuka í tekhníka.

Grynblat, Míkhaíl \& Gurskiy, Anton (comps.) 2005. Legendy í padanní. [Legends and Stories.] Edited by A. Fiadosík. Minsk: Navuka í tekhníka.

Kabakova, Galina 2013. Contes et légendes étiologiques dans l'espace européen. Sous la direction de Galina Kabakova. Paris: Pippa / Flies France.

Kerbelite, Bronislava 2001. Tipy narodnykh skazanii: Strukturno-semanticheskaia klassifikatsiia litovskikh etiologicheskikh, mifologicheskikh skazanii i predanii. [Types of Folk Legends: Structural and Semantic Classification of Lithuanian Etiological and Mythological Legends and Stories.] St. Petersburg: Evropeiskii Dom.

Kuznetsova, Vera 1998. Dualisticheskie legendy o sotvorenii mira v vostochnoslavianskoi fol'klornoi traditsii. [Dualistic Legends about the Creation of the World in the Eastern Slavonic Folk Tradition.] Novosibirsk: Izd-vo SO RAN.

Lammel, Annamária \& Nagy, Ilona 1985. Parasztbiblia: Magyar népi biblikus történetek. [Peasant Bible: Hungarian Biblical Folk Narratives.] Budapest: Gondolat.

Lammel, Annamària \& Nagy, Ilona 2005. La Bible Paysanne: Contes et Légendes. Paris: Bayard.

Lapucci, Carlo 1985. La bibbia dei poveri: Storia popolare del mondo. Milano: A. Mondadori.

Limerov, Pavel (comp.) 2012. Mify, legendy, predaniia komi naroda. [Myths, Legends and Lore of the Komi People.] Syktyvkar: OOO Izdatel'stvo Kola.

Mochul'skiy, Vladimir 1887. Istoriko-literaturnyi analiz stikha o Golubinoi knige. [Historical and Literary Analysis of the Verse about the Book of the Pigeon.] Warsaw: Tip. Mikhaila Zemkevicha. Available at http://relig-library.pstu.ru/ modules.php?name=1995, last accessed on 14 June 2018.

Mochul'skiy, Vladimir 1893. Sledy narodnoi Biblii $v$ slavianskoi $i v$ drevnerusskoi pis'mennosti. [Traces of the Folk Bible in the Slavonic and Old Russian Writing.] Odessa: Tip. sht. voisk Odesskogo voennogo okruga. Available at http://religlibrary.pstu.ru/modules.php?name=2002, last accessed on 14 June 2018.

Panchenko, Aleksandr 1998. Narodnoe pravoslavie. Issledovaniya v oblasti narodnogo pravoslaviya: Derevenskiye suyatyni Severo-Zapada Rossii. [People's Orthodoxy. Studies in the Field of People's Orthodoxy: Village Shrines of the North-West of Russia.] St. Petersburg: Aleteiia.

Pietkiewicz, Czeslaw 1938. Kultura duchowa Polesia Rzeczyckiego: materjaly etnograficzne. [Intangible Culture of Rechitsa Polesie: Ethnographic Materials.] Warsaw: Tow. Naukowe Warszawskie.

Putilov, Boris 1976. Metodologiia sravnitel'no-istoricheskogo izucheniia fol'klora. [Methodology of Comparative-Historical Study of Folklore.] Leningrad: Nauka.

Pypin, Aleksandr 1862. Lozhnyia $i$ otrechennyia knigi russkoi stariny. [False and Renounced Books of Russian Antiquity.] St. Petersburg: Tip. P. A. Kulisha. 
Romanov, Yevdokim 1891. Belorusskii sbornik. Vyp. 4: Skazki kosmogonicheskie $i$ kul'turnye. [Belarusian Collection. Vol. 4: Cosmogonic and Cultural Tales.] Vitebsk: Tipo-litografiia G. A. Malkina.

Romanov, Yevdokim 1912. Belorusskii sbornik. Vyp. 8-9: Byt belorusa: Slovar' uslovnykh iazykov. [Belarusian Collection. Vol. 8-9: The Life of the Belarusians. Dictionary of Conditional Languages.] Vil'na: Tipografiia A. G. Syrkina.

Sen’ko, Ivan 1993. Koli Khristos po zemli khodiv. [When Christ Walked the Earth.] Uzhgarad: Karpati.

Serzhputovskiy, Aleksandr 1911. Skazki i rasskazy belorussov-poleshukov: Materialy $k$ izucheniiu tvorchestva belorusov i ikh govora. [Tales and Stories of Belarusians of Polesye: Materials for the Study of the Belarusians and Their Dialects.] St. Petersburg: Otd. russkogo yazyka i slovesnosti Imp. AN.

Serzhputovskiy, Aleksandr 1930. Prymkhí i zababony belarusaŭ-paleshukoŭ. [Prejudices and Superstitions of Belarusians from Polesye.] Minsk: Belaruskaya akademíya navuk.

Sharakshinova, Nadezhda 1980. Mify buriat. [Buryat Myths.] Irkutsk: Vost.-Sib. kn. izd-vo.

Sheyn, Paval 1874. Belorusskie narodnye pesni, $s$ otnosiashchimisia $k$ nim obriadami, obychiiami $i$ sueveriiami, s prilozheniem ob"iasnitel'nogo slovaria i grammaticheskikh primechanii. [Belarusian Folk Songs, with Related Rituals, Customs and Superstitions, with an Explanatory Dictionary and Grammar Notes Attached.] St. Petersburg: Tipografiia Maikova. Available at http:// knihi.com/Paval_Sejn/Bielorusskije_narodnyje_piesni,_s_otnosiaschimisia_k_ nim_obriadami,_obycijami_i_sujevierijami,_s_prilozienijem_objasnitielnoho_ slovaria_i_hrammaticieskich_primiecanij.html\#1, last accessed on 15 June 2018.

Sheyn, Pavel 1893. Materialy dlia izucheniia byta i iazyka russkogo naseleniia SeveroZapadnogo kraia. [Materials for Studying the Way of Life and Language of the Russian Population of the North-Western Region.] Vol. 2. St. Petersburg: Tipografiia Imperatorskoi akademii nauk.

Sravnitel'nyy 1979 = Sravnitel'nyy ukazatel' syuzhetov: Vostochnoslavyanskaya skazka. [Comparative Index of Plots: East Slavic Tale.] Comp. by L. Barag \& I. Berezovsky \& K. Kabashnikov \& N. Novikov. Leningrad: Nauka.

Sturluson, Snorri 1970. Mladshaia Edda. [Younger Edda.] Leningrad: Nauka.

Sudnik, Tamara \& Tsiv'yan, Tat'yana 1982. O mifologii liagushki. [On the Mythology of the Frog.] In: Balto-slavianskie issledovaniia 1981. Moscow: Nauka, pp. 137-154. Available at http://inslav.ru/images/stories/books/BSI1981\%281982\%29.pdf, last accessed on 15 June 2018.

Tolstoy, Nikita 1983. Poles'e i ego znachenie dlia slavianskoi arealogii. [Polesie and Its Significance for the Slavic Study of Areas.] In: N. Tolstoi (chief ed.) Poles'e $i$ etnogenez slavian. Moscow: Nauka, pp. 6-8.

Toporov, Vladimir 1992. Purusha. In: S. Tokarev (chief ed.) Mify narodov mira. Entsiklopediia. Vol. 2: K-YA. Moscow: Sovetskaia entsiklopediia.

Tradytsyynaya 2004 = Tradycyjnaja mastackaja kultura bielarusaŭ. U 6 t. T. 2. Vitsebskaye Padzvinne. [Traditional Art Culture of Belarusians. Vol. 2: The Vitebsk Part of the Dvina River Region.] Chief editor Vladimir Skorokhodov. Minsk: Belaruskaya navuka. 
Tradytsyynaya 2006 = Tradycyjnaja mastackaja kultura bielarusaŭ. $U$ G t. T. 3. Grodzenskaye Panyamonne. U 2 kn. Kn.2. [Traditional Art Culture of Belarusians. Vol. 3: The Hrodna Part of the Niemen River Region. In 2 Books. Book 2.] Minsk: Vysheyshaya shkola.

Tradytsyynaya 2009 = Tradycyjnaja mastackaja kultura bielarusaŭ. U6 t. T. 4. Brestskaye Palesse. U 2 kn. Kn. 2. [Traditional Art Culture of Belarusians. Vol. 4: The Brest Part of the Polesye Region. In 2 Books. Book 2.] Minsk: Vysheyshaya shkola.

Tradytsyynaya 2011 = Tradycyjnaja mastackaja kuĺtura bielarusaŭ. U 6 t. T. 5 . Tsentral'naya Belarus'. U 2 kn. Kn. 2. [Traditional Art Culture of Belarusians. Vol. 4: The Brest Part of the Polesye Region. In 2 books. Book 2.] Minsk: Vysheyshaya shkola.

Tradytsyynaya 2013 = Tradycyjnaja mastackaja kultura bielarusaŭ. U 6 t. T. 6 . Gomel'skaye Palesse i Padnyaproŭe. U 2 kn. Kn. 2. [Traditional Art Culture of Belarusians. Vol. 6: The Homiel Part of the Polesye and the Dnieper River Regions. In 2 Books. Book 2.] Minsk: Vysheyshaya shkola.

Vèlius, Norbertas 1986. Kaip atsirado žemé: lietuviu etiologinés sakmés. [How the Earth Appeared: Lithuanian Etiological Legends.] Vilnius: Vaga.

Vèlius, Norbertas \& Dapkute, Rita \& Kupcinskaite, Dainova 1998. Lithuanian Etiological Tales and Legends. Vilnius: Vaga Publishers.

Vlasova, Zoya (ed.) 1986. Sobranie narodnykh pesen P.V. Kireevskogo: zapisi P. I. Iakushkina. T. 2: Pamiatniki russkogo fol'klora. [Collection of Folk Songs P. Kireevsky: Records of P. Yakushkin. V. 2: Monuments of Russian Folklore.] Leningrad: Institut russkoi literatury (Pushkinskii dom) \& Nauka.

Volodina, Tatiana 2013. Les légendes anthropogoniques des biélorusses dans le contexte des représentations populaires et des pratiques magiques. In: Contes et légendes étiologiques dans l'espace européen. Sous la direction de Galina Kabakova. Paris: Pippa / Flies France, pp. 185-201.

Vrazhinovski, Tanas 2006. Makedonska narodna Bibliya. [Macedonian Folk Bible.] Skopje: Matitsa Makedonska.

Yastrebov, Nikolay 1993. Bogomily. [Bogomils.] In: S. Averintsev (chief ed.) Khristianstvo: Entsiklopedicheskii slovar'. [Christianity: Encyclopedic Dictionary.] Vol. 1: A-K. Moscow: Bol'shaia Rossiiskaia entsiklopediia, pp. 269-274.

Zowczak, Magdalena 2000. Biblia ludowa: Interpretacje wątków biblijnych w kulturze ludowej. [Folk Bible: Interpretations of Biblical Themes in Folk Culture.] Wrocław: Funna.

Zowczak, Magdalena 2013. Biblia ludowa: Interpretacje wątków biblijnych w kulturze ludowej. [Folk Bible: Interpretations of Biblical Themes in Folk Culture.] Torun: Wydawnictwo naukowe uniwersytetu Mikolaja Kopernika. 


\title{
THE NORM AND ITS DEVIATIONS IN THE CONTEXT OF CHILDHOOD SEMIOTICS: THE BELARUS TRADITION AGAINST THE SLAVONIC BACKGROUND
}

\author{
Tatsiana Valodzina \\ Center for Belarusian Culture, Language and Literature Research \\ National Academy of Sciences, Belarus \\ e-mail: tanja_volodina@tut.by
}

\begin{abstract}
The article is dedicated to the study of early childhood in the context of ideas about its standard flow and deviations which are logical from the point of view of childhood mythology. Infancy in traditional spiritual culture is presented as a rather long period of transition, the period when the child is gradually freed from 'chaotic' signs, overcomes other-worldly influences, the human face of the child is finally appearing, and he or she is finally affirmed as a full-fledged member of society. Infantile diseases appear as the phenomenon stimulated by the very fact of birth and, along with that, a marker of the natural in the human body. Their overcoming becomes one more step on the way to maturing and socialization of a small human being. Child's health in folk representations directly depends on correct (re)distribution of the lot (possessions) both among people and nonhuman residents of the estate. Folklore texts and rituals from early childhood recreate archaic understanding of health as a part of the overall lot. The article is based on the materials of the late nineteenth - early twenty-first centuries: of importance here are the author's records made under a special program in expeditions to Belarusian villages over the last fifteen years.
\end{abstract}

Keywords: Belarus, childhood semiotics, deviations, folklore texts, folk medicine, incantations, transitional ritual

The topicality of the research is stipulated by the absence of generalizing papers dealing with characteristics of healing practices in childhood ethnosemiotics; fragmentary description of folk medicine as an ethnocultural complex consisting of the unity of verbal, action, and other components. Besides, there is a long overdue social and cultural need for paying attention to folk medicine and anthropological knowledge, resulting from an increased demand for the services of alternative medicine doctors among people and, at the same time, expanded non-critical borrowing of parascientific explanatory schemes and models of the 
world in mass culture. Resorting to the folk tradition knowledge brings the issues of ethnopsychology of doctoring to the foreground, when it appears vital to appeal to the harmony of humans with the surrounding world, an idea central to Belarusian folk medicine.

Early childhood, as a period of particular importance, semantically multidimensional and full of symbolic procedures, has definitely attracted attention many times both in Eastern Slavonic folklore studies and in the European ethnography in general. In the Soviet science, Tatiana Tsyvjan was among the first to pay special attention to the semiotics of childhood, analyzing the status of the very child, as well as space and time in the rites of the first forty days after childbirth with the use of Balkan materials (Tsyvjan 1982). The 'transitional nature' of the life-cycle rituals becomes an important topic in Albert Bayburin's concept, whose works are fundamental in the development of a detailed and well-grounded semiotic approach to traditional culture. Through the prism of his views, it appears possible to suggest explanations of a disease as one of the clearly manifested samples of non-correspondence between the biological condition and the social status of an individual, which folk medicine rituals aim to eradicate (Bayburin 1993).

Another particularly important law of the archaic vision of the world is normativity - in Irina Sedakova's early childhood scenario study. Ideas about the norm and the limit are important for all cultural spheres; however, they are particularly well-manifested in traditional views of a child. Each individual has a certain lot, and even in details there is pre-determination and standardization (Sedakova 1999). The incantations of childhood are considered in Tatiana Agapkina's paper (Agapkina 2006).

Early childhood appears in traditional conscience as a certain period of transition, when the child is gradually freed from 'chaotic' signs, overcoming the other-worldly influences, developing his or her human appearance and finally affirming as a full-fledged member of society. Ties with 'that' world for the infant are not yet finally broken; there always remains a threat of backtransition. As Albert Bayburin states, childbirth leads to the appearance of non-correspondence between the very fact of a person's existence and absence of their human status. The goal and tasks of any ritual are to eliminate this noncorrespondence. The strategy of ritual acts of the first year of childhood lies in liberating the newborn from 'natural' characteristics and simultaneously providing them with cultural qualities and characteristics. The ritual development of the human being includes several basic elements: reaching the necessary form (shapes, sizes); obtaining the capacity to see, hear, move, and then 'the inside': the ability to speak, remember, and feel. Naming completes the process of the creating of a new semiotic object, ensuring its accession to the semiosphere. 
It is necessary to provide them with a lot. Simultaneously, there takes place separation of the infant from the 'alien', the natural, and his or her inclusion into the world of people (Bayburin 1993: 60-62). Ensuring calm sleep, ability to learn to walk and speak in time, regulate urination, and acquisition of the first communication skills are considered to be the necessary components of child socialization. Such is the scenario of ritual conduct for every fact of birth. But there occur, in particular, in early childhood, a number of deviations and drawbacks, of which diseases are the most important.

According to ethnography data, infant diseases in the past, up to the midtwentieth century, were a frequent phenomenon, in particular if we take into account quite a high percentage of child mortality. Moreover, a number of specific diseases of the first two months of life can be distinguished. The Belarusians of the Western Dvina basin region separated mesiachnik (month) (Wereńko 1896: 139) and mesiachyna - the period of particular child susceptibility to diseases (Nikiforovskiy 1897: 37). Child diseases are perceived as a manifestation stipulated by the very fact of birth, as well as a marker of the natural in the human body.

\section{CHILD CONVULSIONS AS A MARKER OF INFANCY}

Infantile paralyses, accompanied by epileptic seizures, both inborn and postpartum ones, were a rather wide-spread phenomenon in the nineteenth century, for example "U čylavieka chut́ adzin radzimiec da byvajet, čylaviek biez radzimca ni pumirait'" (Any human must have at least one of such seizures, no human will ever die without having such a seizure) (Dobrovolskiy 1914: 765). People even believed that each human is born with major or minor proneness to epilepsy, but in some people it is manifested by hysterical laughter, while in others - by crying, and yet others - in somniloquence; those who have had none of these will sooner or later be attacked by the evil disease (Nikiforovskiy 1897: 27); compare the same in Russian (Burtsev 1902: 68) and in contemporary records:

Dziecinaje je. Jano ŭ sredzinie buvaje. Eto chorošo, jek vukinie navierch. Dzieckoja chvoroba. Eto chorošo, jek vukinie navierch, i dzicio pokaže. Odno spić, snom prochodzić, druhoje śmiejecca, trecia može plakać. A čacviortoho i pienka moža z rocika pujci. U každaha, u každaha dzicionka, biez etaho nie buvaje. A jak nie vyjdzie, to budzie hodoŭ do siemi tak, orhanizm slabieńki, poka ŭ rost voźmiecca. ${ }^{1}$

The child disease is there. It may be inside. It is good if it gets manifested on the outside. Child disease. It is good if it shows itself, and when the 
child shows it. One infant sleeps, and in sleep it goes, another one laughs, yet another one will cry. Another one will have foam at the mouth. Each, absolutely each child has it. And if not, it will be going like this by the age of seven, the organism is poor, until they start growing.

The origin of the word radzimec is connected to the meaning 'inborn'. In the Pskov region, people differentiate малотник (malotnik) - "u ryabonka byvayet' tak, shto rebonak sausem vot na krayu smerti" (it may happen with the child that he or she is close to dying) (Mekhnetsov 2002: 334), in the adjacent Harodok raion of Belarus - малочай (malochay). The boundaries between the other world and the infant who has come from it are still highly transparent, not reinforced through complex symbolic actions, which become the core of family rites; therefore the child is more vulnerable to diseases.

Along with the recognition of the child's personality in the mother's womb (see Baranov 1999: 15-16), there should also be stressed understanding of its other-worldly nature by traditional conscience. There is a Macedonian belief, according to which a child in the womb is dangerous for the mother, she was tied with a belt to "better detect the enemy" (štopoveḱe grubi dušmano) (Zadrożyńska \& Wrocławski \& Vrazinowski 2002: 41-42). The child in the womb seemingly 'collects evil spirits'. Julian Talko-Hryncewicz characterizes them while describing child convulsions in the Ukrainian folk culture as the ones 'brought from the other world' (Talko-Hryncewicz 1893: 119). In general, such characteristics of the fetus stem from the other-worldly-chthonic interpretation of the woman's womb, understanding of the child as an envoy from the other world and a 'guest' (see a saying in the Belarusian family rite "Boh da nas čužaziemca pryslaŭ, jon z daliokich krajoŭ prybyvaŭ” (God has sent a foreigner to us from distant lands)). The idea of the inborn nature of the disease along with a clear realization of its demonic essence allows to assume the vision of radzimec as a kind of the other-worldly human atavism, as the other-worldly substance, which accompanies baby delivery.

A multi-stage, expanded delivery-baptizing complex basically aimed at liberating the child from the influence of the other world and at their gradual entering the society. Naturally, at a certain stage of baby delivery the mechanism of transition could fail, and a certain part of the other-worldly nature remained in the infant's body, causing convulsions and other epileptic seizures. In this respect, the following magic medical ritual is indicative: The mother sat on the sick child's face with a naked body, closing him or her with her skirt, and said three times: "Wherever you have come from, go there" (Novak 1998: 133). In fact, here it is the disease origin in the other-world space through the woman's maternal passages that is pointed to, and the demon of disease is removed in the same way in which it came to the human world. 
A number of magic actions aimed to treat the radzimec (child convulsions) are meant not to give the child back, but just as an attempt to spread 'that' world in 'this' one. Therefore, it was first recommended to consciously model the anti-world, intentionally overturn everything in the house, to make the house look just the opposite: "The child is put in the baby carriage with their legs to the top, an inturned shirt is put on them with the sleeves on the legs, in the daytime windows are covered or closed, and in the nighttime lighting is made more intensive" (Nikiforovskiy 1897: 38). Here also fits the prescription to cover the child with a black cloth, the Bulgarians even covered the sick child's face and hands with coal, and then forbade to bathe them for nine days and take them out of the house to have it 'blackened there' (Bogdanova 1985: 306); see also a record from Polesia, reading: "Končajecca dityna, ne mohla snuty, plače, jak hlucha nič" (The child is dying, cannot sleep, cries as a dead night). The witch doctor whispered something and advised not to point at them, not to call them by the name and to close the eyes with a black bandage. If you do it for nine days, they will live, otherwise they will die (Strakhov 2005: 175). In the latter case, particularly indicative is the prohibition to call the child by name, their symbolic deprivation of name is one of the brightest indicators of culture. The complexities of each stage of a small human's growing were accompanied by disease manifestations, and their successful combating meant the steps towards the child's entering the society.

\section{CHILDBIRTH AND SHARE RE-DISTRIBUTION}

All the newborns had to go through the main stages of socialization. And socialization proper, which started with the moment when the midwife took the child, cut the umbilical cord on the instruments of labor or on a book, covered with the parents' worn clothes, continued with the first bathing, putting on the first shirt, tying with a belt, ablactating, 'cutting of manacles' at the first step, etc. Through a series of ritual acts the child was included into the society and the world due to necessity, but this was not always smooth and flawless.

The re-distribution of the lot in society (family, village) caused by the childbirth received its ritual manifestation in the post-delivery visits paid to the woman by female neighbors, in the so-called 'old ladies' porridge' at the baptizing ceremony, etc. But in traditional conscience a human being is a component of a more expanded structure than just family-dynasty-village, and the newborn is included as an equal part into the interconnected and complementary society of people - non-people, which, besides humans, includes animals, primarily domestic animals, plants (see a symbolic exchange of health with trees), and 
a whole number of invisible estate residents (starting with home spirits up to evil demons). The appearance of a new unit, a small human being, who is thought of as a gift from beyond-human, sacral spheres, violates the relations set and regulated by a number of ritual prescriptions in this social and mythological structure.

Child's health in this context directly depended on the correct re-distribution of the lot (possessions) among other non-human estate residents. It is indicative that a child has the qualities of his or her neighbors - fur and unregulated cries, borrowed from animals and birds, extra activity at dawn, ability to see the future - from specific spirits, etc. Therefore, obtaining his or her lot of the overall reserve by the child and their ritual treatment is accompanied by regaining the natural characteristics, returning the things that are not theirs and are not necessary to the child to the right address: fur - to an animal, cries - to hens, insomnia - to dawn, etc. It may be said that treatment operations relating to little individuals typologically fit well into the symbolic procedure of re-distribution of the general (collective) lot, of which not only representatives of human society proper are recipients.

An important stage of the child's entering the surrounding space is the regulation of relations with animals (see below the complex relating to diseases of the type strands of fur) and natural and space world, which may be exemplified by a symbolic exchange with the forest spirits and heavenly phenomena (stars, dawn) in the 'texts' of nachnitsas (night owls). Another level is the establishment of parity relations with the demonic world - nachnitsa (night owl), Rus. polunochnitsa, Serbian babice, etc. Warning a child against their harmful effect is supplemented with steps taken to make those demons satisfied. And finally, of importance is the acquisition of the skills of communicating with people, teaching how to behave among people. Failures at this stage could lead to bad behavior.

\section{Relations 'child - natural and space world'}

Up until now, pregnant women have been cautioned against kicking domestic animals, caring too much for them, otherwise there will be hair on the child's back.

Eta jak chadzila maci biaremienna, svinnionka kavirala nahoj. A nikahda nie nada. Vot jej ničoha, a malomu zaŭradzila, ščacińnia vot takoja. Koliecca, vot i kryčyć hvaltam. Nikavo nielzia nahoj. Eta dzicia liečuć. Śvinniej vyhaniajuć sa svinarnika $i$ ŭ hajno, dzie jany liažać. I maloja heta zakapavajuć, na čas zakryvajuć u heta hajno. Jano i liažyć. I jano prachodžaje tady toja šarscinnia. ${ }^{2}$ 
When the mother was pregnant, she pushed a piglet with her leg. And you can't do this. She is okay, but that brought damages to the child, such fur. Spiky, so he is crying inside. You cannot kick anybody. And the child needs to be treated. Pigs are taken from the shed and the child is placed on the straw where they used to be for some time. And he stays there. And the fur will thus disappear.

The ideas about the disease characterized by the appearance of abnormal fur, hair on the body, stress the realization of a certain conditional measure of hair availability, and allow to reconstruct the mythology complex related to the universal idea of correspondence between the biological/social status and the degree of 'hairiness'. At the level of names of such diseases the Belarusians have several rows, united on the basis of manifestations of symptomatic nature: 1) 'sound', which stresses abnormal sound behavior - kryksuny, kryktuny, kraktuny, kraktuchi; kryklivicha, kryklivicy, plaksuny (crybabies); 2) 'visual', which fixes beliefs of appearance of disease-bearing hair on the child's body-valasnik, valasnica, valasianica, svinskaja šersć, šarscinnia, šarscinka, svinnaja šersć, kacinaja kaliučka, dzikija valoski (fur, hair). Ukrainians denote such a disease as volas (Talko-Hryncewicz 1893: 121), the Russians of Siberia - shchetina (bristle) (Vinogradov 1915: 375). The third row can be represented as a 'zoomorphic' one: “Sabačča starasć. Eta takoja šarscinnia vyrastaić. Luhu zavaravajuć, popielu i kupajuć. Takija valaski na spinie ŭ rabionka, jany koliucca"3 (Dog's old age. Such fur grows. Ashes are boiled and the baby is bathed in it. Such hair on the child's back. Spiky); Russian sobachia starost 'insomnia and no appetite of the child resulting from the violation of the ban when a mother steps over a cat' (Olonetsk region; Kulikovskiy 1898: 72); sobachinka (Vologodskaya region; Berezovich 2007: 513). Similar names can be found in other nations - Bulgarian nèceu 'infant disease when they get weaker, and grey fur grows on the body', nѐсùua, пѐснѝuа - the same (BER 1996: 186-187); Serbian nешuцы (Tolstoy 2003: 372); Polish psiarka 'red spots on the child's body' (Karłowicz \& Kryński \& Niedźwiedzki 1912: 413). Rachitis in the Volgograd region was denoted as koshach'i sukhoty (feline tuberculosis) (Berezovich 2007: 513), while Bulgarians pointed to the disease of мачетини (machetini), which appeared as a result of violation of the ban to call a child a cat - machka (Sedakova 2007: 31).

The 'bird' series of child diseases is made up by the names like крылішчь (krylishchy), крылыскка (krylyska), appearing when a hen goes in-between the pregnant woman's legs. Only children at the early infancy stage suffer from those diseases, in some records such semiotically important intervals as a sixmonth age or a year are stressed: "Jak maleńki, do šesti miesiace, buǔajut krylyska" (When an infant, up to six months, there may be krylyska) ${ }^{4}$. Significant seems to be an emphasis on the fact that such disease may disappear on 
its own, when the period of its appearance 'allowed by tradition' expires, as well as an emphasis on the frequency of such behavior of infants, which once again underlines the organic nature of such infant diseases in the first year of life scenario.

The appearance of pimples, fur, and hair on the child's body is perceived as a result of beyond-norm connection of a pregnant woman with pets and birds, the semantics of which contains a chthonic element. This marker is transferred already in the mother's womb, which is symbolically equal to the other world. Excessive, non-regulated contact of a pregnant woman with the creatures opens up access of infernal forces to the child, activates the disease-causing effect of the other-world things on the small human being. Such supernatural hairiness makes the chthonic component in the child's body more intensive and constitutes a marker of the child's nature, not yet overcome by belonging to the other world. In indicative riddles, a child is represented as an animal: "Što za zviaročak: pa chacie chodzie, nichto jamu nie škodzie" (What an animal is it that goes about the house and nobody ousts it) (Zahadki 1972: 344). Worthy of attention is the fact that almost all popular Bulgarian names of unbaptized children coincide with designations of small pets (Walczak-Mikołajczakowa 2001: 32). At the same time, comparison of a child to an animal appears logical since "figuratively, transformation of the child's appearances can be represented, somewhat conditionally, as his or her passing through several conditions: starting with the 'inanimate' substances of nature (rock, bone, root, ovary) and creatures belonging to 'animal nature' of the chthonic circle (amphibians, rodents) to a human being" (Baranov 1999: 26).

Through the prism of disease perception as intervention of a demonic essence into the human body or activation of the 'inborn' chthonic component, treatment was based on the dominant idea of a removal of the 'alien', achievement of the generally accepted norm of 'humanity', one of the manifestations of which is absence of hair (fur) in non-characteristic places. Removal first presupposed a kind of materialization of symptoms, concentration of hair and fur, which were of a concern for the child, in a number of attributes, which include ashes, bread, flour, breast milk. Some records suggest deleting it with saliva or salt. Magic elements of the treatment of 'fighting fire with fire' are manifested in smoothing out with fur - '(smoothed out) with fleece... from a coat's; 'Rolls were made out of a dog's fur and smoothed out on the child's body'6.

Rolled hair was either destroyed or removed into the sphere of beyond-human - '(bread) was thrown behind the stove, for mice to eat it'7; 'thrown to the places where there is nobody'8. The most frequent indication is that such bread was given to the dog to eat: 'Soft bread is taken from kraktunou (crybabies), and rolled on the back. And then it should be placed on the window to stay there, 
and then it is given to the dog'9. In some rare cases the sick child was fumed with the rolled fur (Wereńko 1896: 206). The procedure was conducted in the chronotope typical for folk medicine practices and mainly during/after bathing. The magic inventory was prepared in compliance with certain rules - "three days after bathing to put four heaps of ashes sifted through the top-down sieve on the spade located on the threshold in turns crosswise. To sweep the ashes in the same order into the water and bathe the child" (ibid.). The ashes could be sifted, holding hands behind the back, ${ }^{10}$ and bread was taken from the place where the sign of a cross was put on the dough (Lapatsin 2004: 248). In the beliefs, ashes could by themselves 'absorb' such hair. ${ }^{11}$ Bulgarians bathed the pesčavo dete (sick child) in water with such ashes, and then poured the water onto the cat (Bogdanova 1985: 305).

Baba klala dzicia nicma, nakryvala jaho nočvami. Z-pad kryla čornaje kurycy vyryvala dzieviać pieryn, viazala ich pa try ŭ try pučki, siekla na nočvach nažom. Maci vychodzila za dzviery i pytala: "Što siačeš?” "Krylišča." - "Siačy, kab nie bylo." I tak try razy. ${ }^{12}$

The woman put the child on the back and covered the child with a trough. She took nine feathers from under the black hen's wing, bound them in threes into three bundles and cut with a knife on the trough. Mother went out of the door and asked: 'What are you cutting?' - 'Krylishcha.' - 'Cut for it to disappear.' And three times like that.

In case the ritual was connected with cats and dogs, they were given the bread with rolled hair, while in the context with pigs other mechanisms were accentuated. Bread was not given, the child him- or herself was taken to the swine shed (that's what Lusatian Serbs did for the child to sleep well (Schneeweis 1935: 62), rolled from one place to another there ${ }^{13}$ and "nasili, jak krylišča, u toja stojla, dzie svinni stajać. Kladzie na paroh. Paliažyć, paliažyć i ŭsio” (carried, in case of krylishcha, to the stall where the pig stood. Put on the threshold. (S)he lies there a bit, and that's it) ${ }^{14}$. More frequently recorded as pieces of advice are "to take the child, put him or her under the threshold, cover with a trough, make pigs move across it" (Federowski 1897: 391). The unification of pigs, cats, dogs and hens within one text can be traced in the case of treatment of a 'pig miracle' by Russians in Siberia (Fedorova 2001: 61).

It is indicative that even the spirits bringing harm to children acquire the shape of domestic animals (Biegeleisen 1927: 259, 357). Particularly popular in the ritual treatment of infant diseases were domestic animals. It is essential to find a semantic correlation between the image of a child and small domestic animals and pets (cat, dog, and pig) on the basis of their stressed marginal status between the wild and the mastered (domestic), which is based on their 
separation from the wild and the alien, inability to regulate their physical needs, absence of speaking ability, etc. In any case, fur obtained from domestic animals was given back to them.

When researching the semiotics of crying, including child crying, I. Sedakova appeals to the important law of archaic vision of the world - normativity. Ideas about the norm and the limit are important in all the fields of culture, but they are particularly well-manifested in the traditional views of the child. Each person has a certain destiny, and even details already contain pre-determination and normativity. Each child has a limit of crying (loudness and duration), which, if exceeded, does not fit within the limits of the regulated world. Excessive crying is perceived as inhuman and is connected in the traditional conscience with the limit of nature and culture or goes into the field of demonology (Sedakova 1999: 113).

The same can be said about the child's hair, since its appearance in excessive, or, vice versa, insufficient amount stresses the realization of a certain conditional limit of hair, deviation from which causes painful symptoms and is in itself qualified as not just a disease, but the intervention of the alien and demonic. The ban to cut hair and nails until the child is one year of age is among the most wide-spread bans, and the most frequent motivation is the danger to cause delays in the speaking ability manifestation. Tradition recognized the 'alien nature' of those parts of the body and therefore any striving to adjust growth was of a ritual nature. Human transition from one age group to the other one was normally accompanied by manipulations with hair. The first haircut, marked by a ritual, provokes the ability to speak, and finally pre-determines the status of the individual. The adjustment of 'hair degree' and removal of beyond-norm part of it also constituted a necessary step towards growing up of a little human.

Uncontrolled urination is a norm for an infant, the same as incapacity to walk or talk. Absence of control over this physiological function of the organism in a certain sense makes a child like an animal, pointing to the 'natural', 'elemental' in humans. But the first skills of 'potty-training' a child approximately coincide with the first progress in mastering speech, with improvement of motor functions, etc. Therefore, ritual regulation of that process can be considered as one more component of child socialization, his or her consistent affirmation in human status (Valodzina 2004). 


\section{Relation 'child - the world of demons'}

Dependence of a child on different infernal forces, subordination to them, and a respective need to communicate with them found their manifestation in a complex of ideas about specific children's spirits and demons, which, due to their demonic nature, could cause insomnia and disease-caused crying of children. In Belarus those demons are called начніца (nachnitsa, night owl) (see other versions, such as начнікі (nachniki), крыксы (kryksy), плаксы (plaksy), крактуны (kraktuny), etc.). In P.V. Shein's collection, "nachnitsas are presented as women in dark clothing (more rarely - in white dresses), they come in a barely audible way, sit on the bed and touch humans with their hands. As a result of that, he or she becomes insomniac and can even die" (Shein 1893: 537-538).

Permanent crying of the child in the nighttime proved that nachnitsas resided in the house and were bringing harm to the child. One of the locusesshelters of nachnitsas was the stove, since it was here that sacrifices were offered to them:

You need to take a slice of bread with salt, cover it with a white wipe, tie with a red thread, and then take the child and pat his or her head with this knot and put it on the stove. And then bow three times to the stove without making the sign of the cross and say: 'I am giving you, kriksas, bread and salt, white shirt, red belt, give good health and sleep to my child'. (Romanov 1891: 31)

It appears that kriksy, nachnitsas cannot only take sleep away, but also 'give' it; see also a saying from Polesia: "Načnicy, načnicy, na dziciatka son naviedzicie..." (Nachnitsas, nachnitsas, give sleep to the child...) (Polissya 2003: 71). It was under the stove that other home spirits resided, and primarily that was the bogey that could also perform some patronage functions. Here is an indicative folklore fact from the Hrodna region:

A baba Handzia havaryla, što jeść try vida damavych. Damavy, katory niačystaja sila; damavy, katory spryjaje; $i$ damavy, katory dzieci kalyša. Maje dzieci ŭsio nie spali, tak ja vyjdu i kažu: Baba hadavanka, dzie toj damavy, što dzieci kalyša? ${ }^{15}$

And old lady Handzia said that there are three types of bogeys. A bogey that is an evil one, a bogey helping you, and a bogey singing lullabies to children. My children did not sleep well, so I went out and said: Where is the bogey singing lullabies to children?

Possibly, nachnitsas/kryksas were one of the forms of embodiment of domestic spirits, which, in turn, are genetically linked to the souls of the ancestors living 
in that house. The folk tradition regulated relations between living and similar 'residents' of the house with the frame of the 'peaceful co-existence'. In case the 'agreement' was violated and 'the other' party interfered in human affairs, it became necessary to neutralize it and to re-set the boundaries. Success in treatment could be ensured through a combination of magic actions, when the neutralization of excessive disease-causing activity of spirits-nachnitsas was combined with the re-distribution of space and possessions, as well as the removal of supranormative demonic remains out of the house, but - and that is important! - to the locuses of their shelters within the estate. Such simultaneously 'own' and 'alien', specific demonic locus is a heap for litter as a magnetic concentration of the chthonic nature and direct way to the other world. "A child is placed on the bedsheet spread on the floor in the middle of the house, then litter from everywhere is swept to him/her, and then the bedsheet with the child is taken out of the house to the litter heap and thrown away" (Vasilevich 1999: 181). A locus that belongs to such spirits as well (old and young) is also the corner of the house:

Biareš dzicia nosiš jaho, treba havaryć: "Va imia Ajca i Syna i prašu Maniu i Hospad Boh pamažy.” A tady: "Dobry viečar!” I niasieš jaho na kut spierva. "Dobry viečar, staryja i malyja, dajcia Koliu son.” Tady niasieš u druhi kutok, tady u toj, tady ŭ toj (nakryž pakazvaje) "Dobry viečar, staryja i malyja, my nie huliać $k$ vam pryšli, kryksy i načnicy pryniasli”. Pierachrysciš i niasieš u druhi kutok. "Dobry viečar, staryja i malyja, my nie huliać $k$ vam pryšli, kryksy i načnicy pryniaśli. Vam plakać, nie spać, a majmu Koĺku spać, huliać, tancavać, apiecit nahaniać."16

You take the child in your arms and carry him or her, saying 'In the name of the Father, and the Son, and Manya [name of the whispering lady] and let God help'. And then: 'Good evening,' - and take him or her first to the red corner. 'Good evening, old and young, give sleep to Kolya.' Then you take him to that corner (the opposite one), then to the other two (to make the sign of the cross). 'Good evening, old and young, we have not come here to have a walk, kryksas and nachnitsas - that's whom we have brought. For you - crying and no sleep, and for my Kolya - sleep, walk, dance, and have a good appetite.'

The analysis of such rituals enables us to perceive nachnitsas as a kind of domestic spirits, the system of functions of which included tracing and regulation of upbringing operations. Only a newborn child, right after coming 'from there' and due to his semi-other-worldly nature, penetrated into the field of their possessions and guardianship possibilities. The function of taking care of the child and ensuring his healthy sleep is also ascribed to 'kukolkas' (dolls) 
(a real materialization of domestic spirits), which were placed on the window: "If a nachnitsa gets to the child, you need to make dolls of dirty wipes, place two or three of them on each window and say: 'Look, dolls, my child needs to sleep well!' - otherwise nachnitsas will come" (Federowski 1897: 270). An emphasized female look of nachnitsas was manifested in a number of functions they seemed to have - and that is some connection with the sphere of reproduction and weavery.

Divčyny iz lučyny robliać veratino, pad holovu kladuć. Nočnycu uhavarvajuć: "Nočnyca, šerańka! Ne ihraj moim ditynam, ihraj veratinom da lapačkaju."17

A spindle is made for a girl out of a rod and placed under her head. Nachnitsa is told: 'Nachnitsa, the grey one, don't play with my child, play with the spindle and the wipe.'

Weaving and child care fit well into the traditional structure of the female variant of a domestic spirit, for whom such occupations were immanent. On the other hand, some contexts point to a possible stipulation of nachnitsas by the very fact of child birth, to their 'inborn' belonging to each person. If we address the rituals of offering a spindle to a girl and a bow to a boy, of interest is the dependence of the gift on the child's gender, in correspondence with which the character for the ritual was attributed by gender. Thus, the specificity of the image of the nachnitsa was "her lack of independence and even mirror reflection, since her characteristics are the projection of the child whom she was to influence" (Fadeeva 2000: 38). In other words, night disease-causing spirits still appear together with the child, accompany his or her birth and the first years of life. Indicative is the fact that the child is called by the names of spirits Ukrainian krieksoj, maroj, ničkoju, as if he or she has absorbed the features of those mythological creatures (Bogdan 1987: 194). Incantations partially identify nachnitsas with children, and such identification was further developed in the motives of 'nachnitsa's insomnia' and 'making nachnitsa fall asleep' (Agapkina 2006: 26). The ritual practice in which "ot nočnyc prača ŭpovyvaly, vykidaly za oknu. Vykinut tuju nočnyciu praz okno: kab uže taja nočnycia na toj prač uzliezla"18 (the gingerbread was swaddled against nachnitsas and thrown out of the window. One should have thrown the nachnitsa out of the window for her to already get on the gingerbread) and at the same time this gingerbread that was the embodiment of nachnitsas persistently assigned the image of the child (Szukiewicz 1910: 116). 


\section{Relations 'child - society'}

Before the child is fully affirmed in the society, it is necessary to set contacts inside the purely children's community. The ideas relating to this stage are reflected in a set of beliefs about a specifically Polesian child disease - znos (знос). Знос (znоs), зносінь (znоsiny) is an accidental meeting of two mothers with children on the way (the first meeting of children is meant). Such meeting is highly undesirable, since, according to a popular belief, one of the children who is above the other will take away his or her force, and the latter will stop growing, will start crying and being ill, and may even die. To become a winner in such meetings, children were taken up, tossed up. "Ona vyšej podniala. Koli jeje dzicia moje pobiedzilo, to jeje budzie zdorovoje, a moje budzie plakać"19 (She put him higher, if her child wins, he/she will be healthy, while my child will cry). The action part of the ritual is reinforced with the verbal one: the mother pronounces aloud or in her mind the following phrase-incantation: "Maja vaŭčenia, a tvaja - kozlienia. Maje tvaje zjesć" (Mine is a little wolf, while yours is a little goat. Mine will eat yours) (Salavey 2006: 92).

While researching child diseases in the social context, it is important to know that the health and destiny of little children seemed to be joint ones, they were not shared by several children in equal parts, and the child was to obtain his or her lot, as it seemed, at the expense of another child. The incantation formulas primarily show striving for providing children with equal, same parts: "Odyn svit, odyn mir, / Odnakovy batky, odnakovy matky, / Nechaj budut odnakovy dytky" (One light, one world, same fathers, same mothers, let children be the same) (Polissya 2003: 87), for ensuring 'just' division between them: "U jaho holovka, u toho holovka, u jaho pliečyca, u toho pliečyca, u jaho sustaǔčyki, u toho sustaǔčyki" (This one's head, that one's head, this one's shoulders, that one's shoulders, this one's joints, that one's joints $)^{20}$. Such division organically includes everything around, when the disease was sent to the place where it attacked the person (it was recommended to take some sand at the place where the meeting had taken place, bathe the child in the water with this sand and pour the water out onto the same place) (Polissya 2003: 84), and children's health was seen in 'space' parallels: "Soniejka i miesiačyk, i vas, dzietki, dvoje, - žyvicie aboje" (The sun and the moon, and there are two of you, children, - live both) ${ }^{21}$.

Getting rid of whims due to their perception as a disease presupposed not upbringing activities and not moralizing, but radical medical procedures. The etiology of the disease, which was often brought down to appearance of a harmful substance in the body, presupposed its removal and expulsion. Hence the predicate expel in the terminologically stable designations of folk medicine manipulations: “...usio kariožycca, plačyć, jetyja kaprizy nada čym-niebudź 
vyhaniać" (...tumbles, cries, these whims need to be expelled) (Bialkevich 1970: 221); "Vyhaniali karady dzierkačom" (Whims were expelled with an old broom);22 "Biaruć dubiec tonki, adžaruć, adžaruć, tyja naravy vyhaniajuć" (They take a thin oak branch, beat him, beat, and expel the whims) ${ }^{23}$ Folk therapeutical rituals of getting rid of whims in the most general form can be represented as follows: the sick child was placed into the locus with meditative semantics and beaten with specially prepared rods.

A kapryzy byvajuć, što pavalicca? - Jak pariucca ŭ bani vienik, nada toj vienik razabrać i najci takuju vietačku, katora tri, štob tri sučki bylo i jetym nada ściebanuć $i$ raz, i druhi, raziki tri. Boĺna nie, a ściebaješ. ${ }^{24}$ And whims may be that [the child] falls down? - While in a bath, one needs to disassemble the broom and find the rod having three knots, and beat the child three times. Not to cause pain, just mildly.

In the absolute majority of records, the ritual action takes place at the house threshold. The sick child is put at the threshold, in some cases - with his or her head to the exit, to the anteroom, which intensifies the vector of disease expulsion. Depending on the further ritual step, either the attribute of the rite is thrown out of the house or the very child is taken out of the house; see also "Eta nazyvajecca upiry. Nu dyk havorać, budta by ad paroha načynajuć etaha dzicionka da abrazoŭ vo tak vo halavoj kuliać. Eta ŭpiry"25 (These are upiry. They say that they start making the child tumble up to the red corner from the threshold. That results from whims).

\section{CONCLUSIONS}

Early childhood has shown the following segments: relations 'child - natural and space world' are characterized by their set of diseases (kraktuny, ščacinka, šarscinka, etc.) and are aimed at the ritual regulation of relations with the ani$\mathrm{mal}$ as well as the natural and space world. This is illustrated by the symbolic exchange with domestic animals in the text of načnic/kryksaŭ. The adjustment of 'hairiness' and removal of its abnormal part constituted the necessary step to be made towards maturity of the little human. The next level is the establishment of parity relations 'child - the world of demons'. Protection of the child from the harmful influence of demons is supplemented with measures taken to cajole disease-causing spirits like načnic, kryksaŭ. But some contexts point to the possible pre-determined nature of nachnitsas caused by the very fact of childbirth. Incantations and rituals demonstrate symbolic inclusion of nachnitsas into a single complex which started in the period of the woman's 
pregnancy and lasted up to the final affirmation of the child in this world. And, finally, topical is the acquisition of the skills of communicating, learning how to behave among people. Failure in relations 'child - society' could result in bad behavior, as well as be manifested in a set of beliefs about a specific Polesian child disease - znos.

Almost each of the child's physiological abilities in folk beliefs acquires a number of characteristics, which points to their changeable status. Voice, availability of teeth, hair, appetite, ability to walk, talk, and control urination are inherent in each child (human), but any deviations from the average manifestation of these functions are considered to be disease-caused and are accounted for by the reasons of sign character: charm, demons' impact, violation of rules of conduct and bans, etc. In its turn, the first manifestation of almost each of the characteristics seems to be semiotically significant: appearance of the first tooth, the first step (see the holiday Prestypulka in Macedonia 'the day of the first step' (Walczak-Mikołajczakowa 2001: 39). Alongside medical manipulations, it is possible to consider both first bathing and baptizing, which are full of ritual and symbolic sense. The first years of life can be relatively perceived as a chain of transformations, the semantics of which is manifested in a number of indicators: attributes - hairy / smooth, naked; toothless / with teeth; dirty (with unregulated excretory system) / clean; predicates - to sit / to walk; to keep silent / to speak; to sleep / to stay awake, etc. As we can see, the left parts of the pairs form a paradigm of description of the alien, non-human / demonic, sickly, negative. "The description of a child, his or her internal nature and external appearances in the child/adult pair, is performed through negative, distorted signs" (Baranov 1999: 26).

Child diseases in the traditional sense are rejoinders of the other world, manifestation of not yet clear chaotic natural signs and, along with that, a phenomenon pre-determined by the very fact of birth. Healing strategies consist, therefore, not in the straightforward removal or destruction of disease-causing demons (cf. načnicy/kryksy), but in the establishment of parity relations with them. The ideas about diseases of the kraktunoŭ (valasianica, šarscinka, krylyska) type stress the realization of a certain conditional measure of hair availability and enable to reconstruct the mythological complex connected to the universal idea of correspondence between the biological/social status and the degree of 'hairiness'. The idea of correct re-distribution of the lot at all the levels of the universe becomes central to the disease-free maturity of the child. Making sleep calm, timely appearance of the ability to walk and speak, to regulate urination, mastering the rules of cultural communication, and equalizing of the appearances are considered to be the necessary components of any child's socialization. 
The idea of the new birth of the child is organically combined with the need for his or her 'correct' inclusion in this world, provision of the child with his or her own lot. Overcoming the marginal condition of the child points to some national implications, while prevention and therapeutical procedures confirm the idea of the need for harmonious co-existence of humans and the surrounding world with all its infinity.

\section{ACKNOWLEDGEMENTS}

The article was written as part of a project financed by the Foreign Ministry of Estonia through the Developmental Cooperation Programme (66-2015-A).

\section{NOTES}

1 Recorded in 2009 by T. Valodzina in the village of Perarou Mlynok, Zhytkavichy raion, Homel region, from Eva Adamauna Baran, born in 1946, and Nadzeja Adamauna Shved, born in 1927. In case no collector is further indicated, the records are those collected by the author.

2 Recorded in 2014 in the village of Lyubushany, Berazino raion, Minsk region, from Zinayida Mikhaylauna Karen, born in 1930.

3 Recorded in 2005 in the village of Valyntsy, Verkhniadzvinsk raion, Vitsebsk region, from Adelaida Filipauna Sheverduk, born in 1930.

4 Polesia Archive of the Institute of Slavonic Studies of the Russian Academy of Sciences; recorded in 1985 by V. Sannikava in the village of Lapatsin, Pinsk raion, Brest region.

5 Recorded in 2004 in the village of Ladasna, Lepel raion, Vitsebsk region, from Yefrasiniya Dzianisauna Kavalenka, born in 1939.

6 Recorded in 2007 in the village of Redziherava, Luninets raion, Brest region, from Uljana Piatrouna Parfianovich, born in 1928.

7 Recorded in 2006 in the village of Kukhoni, Ushachy raion, Vitsebsk region, from Varvara Laurentsjeuna Lytvyn, born in 1927.

8 Recorded in 2006 in the village of Shylintsy, Dokshytsy raion, Vitsebsk region, from Yauheniya Hryhorjeuna Sobal, born in 1925.

9 Recorded in 2003 in the village of Sialets, Chashniki raion, Vitsebsk region, from Matrona Kirylauna Kapustsina, born in 1909.

${ }^{10}$ Recorded in 2003 in the village of Sialets, Chashniki raion, Vitsebsk region, from Valiantsina Paulauna Piasetskaya, born in 1931. 
${ }^{11}$ Recorded in 1998 in the village of Yahadki, Ushachy raion, Vitsebsk region, from N.M. Bulaeva, born in 1913.

${ }^{12}$ Folklore Archive of the Scientific and Educational Laboratory of Belarusian Folklore of the BSU; recorded in 1998 by H. Lapkouskaya in the village of Pastarynje, Baranavichy raion, Brest region, from Lapkouskaya Lidziya Piatrouna, born in 1949.

${ }^{13}$ Folklore Archive of the MSPU (FA): recorded by L. Dulinets in the village of Mosar, Hlybokaye raion, Vitsebsk region, from Hunefa Vitoldauna Panfilko, born in 1919.

${ }^{14}$ Recorded in 2005 in the village of Alkhouka, Liakhavichy raion, Brest region, from Hanna Mikalayeuna Smarchok, born in 1930.

${ }^{15}$ Recorded in 1999 by A. Bohaneva in the village of Koniukhi, Vaukavysk raion, Hrodna region, from N. Harokhava, born in 1949.

${ }^{16}$ Recorded in 2013 in the village of Slabodka Sushanskaya, Klichau raion, Mahiliou region, from Maryia Yafimauna Lapunova, born in1928.

${ }^{17}$ FA: recorded by $\mathrm{H}$. Shgurko in the village of Sporava, Biaroza raion, Brest region, from Alena Datsevich.

${ }^{18}$ Belarusian Folklore-Ethnolinguistic Atlas; recorded by M.P. Antropau in the village of Belsk, Kobryn raion, Brest region.

${ }^{19}$ Recorded in 2007 in the village of Vulka 2, Luninets raion, Brest region, from Tatsiana Yafimauna Viachorka, born in 1935.

${ }^{20}$ FA: Recorded in 2003 by M. Razhalouski in the village of Starozhka, Zhytkavychi raion, Homel region, from Hanna Fiodarauna Yadvila, born in 1923.

${ }^{21}$ Recorded by V. Krasouskaya in the urban settlement of Aktsiabrski, Homel region, from Pelaheya Lukjanauna Sboryna, born in 1925.

${ }^{22}$ PA: Recorded in 1982 by A. Lebedzeva in the village of Dubrauka, Dobrush raion, Homel region, from Yeudakiya Ivanauna Danilchanka, born in 1912.

${ }^{23}$ Recorded in 2002 in the village of Vialiki Pousvizh, Lepel raion, Vitsebsk region, from Mariya Isaakauna Ivanava, born in 1933.

${ }^{24}$ Recorded in 2011 by T. Valodzina and U. Lobach in the town of Haradok, Vitsebsk region, from Yauheniya Fiodarauna Dzemianenka, born in 1936.

${ }^{25}$ Recorded in 2009 in the village of Stsiapy, Zhlobin raion, Homel region, from Katsiaryna Vasiljeuna Zhurauliova, born in 1934. 


\section{REFERENCES}

Agapkina, Tatiana 2006. Syuzhetika vostochnoslavyanskikh zagovorov v sopostavitel'nom aspekte. [The Plots of Eastern Slavonic Charms in the Comparative Aspect.] In: S.M. Tolstaya (ed.) Slavyanskiy i balkanskiy fol'klor: Semantika i pragmatika teksta. [Slavonic and Balcan Folklore: Text Semantics and Pragmatics.] Vol. 10. Moscow: Indrik, pp. 10-123. Available at http://inslav.ru/images/stories/pdf/SBF2006.pdf, last accessed on 13 April 2018.

Baranov, Dmitriy 1999. Obraz rebenka v predstavleniiakh russkikh o zachatii i rozhdenii. [The Image of Child in Russian Perceptions of Conceiving and Birth.] Extended summary of $\mathrm{PhD}$ thesis. Saint Petersburg State University. Available at http:// www.academia.edu/6232107, last accessed on 18 April 2018.

Bayburin, Albert 1993. Ritual v traditsionnoy kul'ture: Strukturno-semanticheskiy analiz vostochnoslavyanskikh obryadov. [Ritual in Traditional Culture: Structural and Semantic Analysis of Eastern Slavonic Rites.] St. Petersburg: Nauka.

BER 1996 = Georgiev, V. \& Glbov, I. \& Zaimov, Y. \& Ilchev, S. (comps.) Bŭlgarski etimologichen rechnik. [Bulgarian Etymological Dictionary.] Vol. 5. Sofia: Bulgarian Academy of Science.

Berezovich, Elena 2007. Yazyk i traditsionnaya kul'tura: Étnolingvisticheskie issledovaniya. [Language and Traditional Culture: Ethnolinguistic Studies.] Moscow: Indrik.

Bialkevich, Ivan 1970. Krajovy sloŭnik uschodniaj Mahilioǔščyny. [Regional Dictionary of Eastern Mogilev Region.] Minsk: Navuka i Tekhnika.

Biegeleisen, Henryk 1927. Matka i dziecko w obrzędach, wierzeniach i zwyczajach ludu polskiego. [Mother and Child in the Rites, Beliefs and Customs of the Polish People.] Lwów: Ateneum.

Bogdan, Svetlana 1987. Svít polís'koî ditini: língvístichní rariteti. [The World of Polessye Child: Linguistic Rarities.] Políssya: Etníkos, traditsî́; kul'tura. [Polessye: Ethnikos, Traditions, Culture.] Lutsk: Vezha, pp. 193-199.

Bogdanova, A. 1985. Narodna meditsina. [Folk Medicine.] In: R. Todorov (ed.) Kapantsi: Bit $i$ kultura na staroto bŭlgarsko naselenie $v$ severoiztochna Bŭlgariya. Etnografski i ezikovi prouchvanie. [Kapantsi: The Daily Life and Culture of Old Bulgarian Population in North-Eastern Bulgaria. Ethnografic and Linguistic Studies.] Sofia: Publishing House of the Bulgarian Academy of Sciences, pp. 279310 .

Burtsev, Aleksandr 1902. Obzor russkogo narodnogo byta Severnogo kraya. [The Review of Russian Folk Daily Life of the Northern Land.] Vol. 2. St. Petersburg: Typ. I. Efron.

Dobrovolskiy, Vladimir 1914. Smolienskij oblastnoj slovaŕ. [Smolensk Regional Dictionary.] Smolensk: Tip. P.A. Silina.

Fadeeva, Liudmila 2000. Simvolika strastnykh ikon Bogoroditsy v zagovorakh. [The Symbolic of the Passion Virgin Icons in Charms.] Traditsionnaya Kultura [Scientific Almanac], No. 2, pp. 35-42. 
Federowski, Michał 1897. Lud Białoruski na Rusi Litewskiej. Materiaty do etnografii stowiańskiej zgromadzone w latach 1877-1905. T. 1. [Belarussian People in Lithuanian Rus. Materials for Slavic Ethnography Collected in 1877-1905.] Vol. 1. Kraków: Wydawn. Komisji Antropologicznej Akademii Umiejętności w Krakowie.

Fedorova, Valentina 2001. Chelovek $i$ slovo v zagovore. Yuzhnoye Zaural'ye: Konets XX veka. [Humans and Word in Charms. South Zauralye: Late 20th Century.] Kurgan: Publishing House of Kurgan State University.

Karłowicz, Jan \& Kryński, Adam \& Niedźwiedzki, Władysław 1912. Słownik języka polskiego. [Polish Dictionary.] T. 5. Warszawa: Kasa im. Mianowskiego.

Kulikovskiy, German 1898. Slovar' oblastnogo olonetskogo narechiya v yego bytovom i etnograficheskom primenenii. [The Dictionary of Regional Olonetsk Dialect in Its Daily Life and Ethnographic Applying.] St. Petersburg: Edition of the Department of the Russian Language and Literature of the Imperial Academy of Sciences.

Lapatsin, Genadz 2004. Z vopytu vyvučennia tradycyjnaj kultury Vietkaǔščyny: Vioska Bartalamiejeŭka. [From the Experience of Studying Traditional Culture of Vetkovshchyna: The Village of Bartalameyeuka.] In: H. Niačajeva (ed.) Navukovyja zapiski Vietkaŭskaha muzieja narodnaj tvorčasci: Zborn. art. [Scientific Notes of the Vetka Museum of Folk Creativity: Collection of Articles.] Homieĺ: Vietkaŭski muziej nar. tvorčasci, pp. 231-254.

Mekhnetsov, A. M. (ed.) 2002. Narodnaya traditsionnaya kul'tura Pskovskoy oblasti: Obzor ekspeditsionnykh materialov iz nauchnykh fondov Fol'klorno-etnograficheskogo tsentra. [Folk Traditional Culture of Pskov Region: Review of Expedition Materials from Scientific Funds of the Centre of Folklore and Ethnography.] In 2 vols. Pskov: Pskovskii gosudarstvennyi oblastnoi Tsentr narodnogo tvorchestva.

Nikiforovskiy, Nikolay 1897. Prostonarodnyye primety i pover'ya, suyevernyye obryady i obychai, legendarnyye skazaniya olitsakh i mestakh. [Folk Omens and Beliefs, Superstitious Rites and Customs, Legends about People and Places.] Vitsebsk: Gubernskaja tipo-litografija.

Novak, V. S. (ed.) 1998. Abradavy faĺklor Homieĺskaha Paliessia. [Ritual Folklore of Gomel Polessye.] Homieĺ: Homiel. centr navuk.-techn. i dzielavoj infarmacyi.

Polissya 2003 = Polesskiye zagovory (z zapisyakh 1970 - 1990 gg.). [Polessye Charms (in the Records of the 1970s-1990s).] Comp. and preparation of text commentaries by T.A. Agapkina \& E.E. Levkiyevskaya \& A.L. Toporkov. Moscow: Indrik.

Romanov, Evdokim 1891. Belorusskiy sbornik. Vyp. 5: Zagovory, apokrify i dukhovnyye stikhi. [The Belarusian Collection. Issue 5: Charms, Apocrypha and Spiritual Poems.] Vitsebsk: Tipo-litografiia G. A. Malkina.

Salavey, Liya 2006. Znosiny, znos. In: S. Sanko (ed.) Belaruskaya mífalogíya: Entsyklapedychny sloŭník. [Belarusian Mythology: Encyclopaedic Dictionary.] Minsk: Belarus, pp. 192-193.

Schneeweis, Edmund 1935. Grundriss des Volksglaubens und Volksbrauchs der Serbokroaten. Celje: Družba sv. Mohorja.

Sedakova, Irina 1999. Krik v pover'iakh i obriadakh, sviazannykh s rozhdeniem i razvitiem rebenka. [Cries in the Beliefs and Rites Connected with Childbirth 
and Child Development.] In: S.M. Tolstaya (ed.) Mir zvuchashchii i molchashchii: Semiotika zvuka i rechi v traditsionnoi kul'ture slavian. [The Sounding and Silent World: The Semantics of Sound and Speech in the Traditional Culture of the Slavs.] Moscow: Indrik, pp. 105-122. Available at http://inslav.ru/images/stories/ pdf/1999_mir_zvuchaschij_i_molchaschij.pdf, last accessed on 13 April 2018.

Sedakova, Irina 2007. Lingvokul'turnye osnovy rodinnogo teksta bolgar. [Linguo-Cultural Basics of Family Text of Bulgarians.] Extended summary of PhD thesis. Moscow: The Institute of Slavonic Studies. Available at http://www.ruthenia.ru/folklore/ sedakova2.htm, last accessed on 13 April 2018.

Shein, Pavel 1893. Materialy dlia izucheniia byta i iazyka russkogo naseleniia SeveroZapadnogo kraia. [Materials for Studying the Way of Life and Language of the Russian Population of the Northwestern Territory.] T. 2. St. Petersburg: Imperatorskaia Akademiia Nauk.

Strakhov, Aleksander 2005. Polesskiye fol'klorno-etnograficheskiye materialy v sovremennykh zapisyakh: 2. Zagovory i narodnaya meditsina. Publikatsiya i kommentarii A.B.Strakhova. [Polessye Folklore and Ethnographic Materials in Modern Records: 2. Charms and Folk Medicine. Publication and Comments by A.B. Strakhov.] Palaeoslavica, Vol. 13, No. 2, pp. 163-204.

Szukiewicz, Wandalin 1910. Niektóre wierzenia, pszesądy i zabobony ludu naszego, legendy i podania. [Some of the Beliefs, Prejudices and Superstitions of Our People, Legends and Traditions.] Kwartalnik Litewski, Vol. 2, pp. 85-102; Vol. 4, pp. 111-124.

Talko-Hryncewicz, Julian 1893. Zarysy lecznictwa ludowego na Rusi potudniowej. [Essays of Folk Medicine in Southern Russia.] Kraków: Nakładem Akademii Umiejętności.

Tolstoy, Nikita 2003. Ocherki slavyanskogo yazychestva. [Essays on Slavonic Paganism.] Moscow: Indrik. Available at http://inslav.ru/publication/tolstoy-n-i-ocherkislavyanskogo-yazychestva-m-2003, last accessed on 16 April 2018.

Tsyvjan, Tatiana 1982. Prostranstvo i vremya v balkanskikh okhranitel'nykh obryadakh, svyazannykh s rozhdeniyem rebenka. [Space and Time in the Balcan ChildbirthRelated Protection Rites.] Macedonian Folklore, Vol. 29-30, pp. 117-123.

Valodzina, Tatsiana 2004. Iz narodnoj miediciny bielorusov. [From the Folk Medicine of Belarusians.] Zhivaja Starina [Living Antiquity], No.1, pp. 37-38.

Vasilevich, U. (comp.) 1999. Ziamnaja daroha ŭ vyraj: Bielaruskija narodnyja prykmiety $i$ pavierji. In 3 vols. [The Earthly Road to the Paradise: Belarusian Folk Beliefs and Superstitions.] Minsk: Mastatskaya Litaratura.

Vinogradov, Georgiy 1915. Samovračjevanije i skotoliečjenije u russkoho starožiloho nasielienija Sibiri (Matierialy po narodnoj miedicinie i vietierinarii). Vostočnaja Sibiŕ, Tulunovskaja volost́, Nižjeudinskij ujezd, Irkutskaja hubiernija. [SelfTreatment and Animal Treatment by Russian Long-Standing Inhabitants of Siberia (Materials in Folk Medicine and Veterinary). Eastern Siberia, Tulunovsk Volost, Nizheudin Ujezd, Irkutsk Province.] Zhivaja Starina [Living Antiquity], Vol. 24, No. 4, pp. 325-432. Available at https://www.booksite.ru/jiv/1915_4.pdf, last accessed on 16 April 2018. 
Walczak-Mikołajczakowa, Mariola 2001. Batkańskie rytmy życia: Czyli o tradycji przechowanej $w$ języku. [Balkan Rhythms of Life: That Tradition is Hidden in the Language.] Gniezno: Gnieźnieńska Firma Wydawnicza "TUM”.

Wereńko, Frantiszek 1896. Przyczynek do lecznictwa ludowego. [Contribution to Folk Healing.] Materiaty antropotogiczno-archeotogiczne i etnograficzne. [Anthropological, Archaeological and eEhnographic Materials.] Vol. 1. Kraków: Nakladem Akademii Umiejetnos'ci, pp. 99-229.

Zadrożyńska, Anna \& Wrocławski, Krzysztof \& Vrazinowski, Tomas 2002. Ludowe obrzędy i podania: Etnograficzne i folklorystyczne studia porównawcze wsi polskiej $i$ macedonskiej. [Folk Rituals and Ideas: Ethnographic and Folklore Comparative Studies of the Polish and Macedonian Villages.] Warszawa: UW IEiAK.

Zahadki $1972=$ Zahadki. [Riddles.] Compiled by M.I. Hrynblat \& A.I. Hurski. Minsk: Navuka i Tekhnika. 


\title{
WORLDVIEW OF BELARUSIAN FOLK SONG LYRICS
}

\author{
Yanina Hrynevich \\ Center for Belarusian Culture, Language and Literature Research \\ National Academy of Sciences, Belarus \\ e-mail: yaninahrynevich@gmail.com
}

\begin{abstract}
This article concentrates on Belarusian folk song lyrics. Song lyrics were first recorded in the 1840s. Today, Belarusian folk song lyrics are a sufficiently widespread genre in the countryside. Although new plots are not created, plots known from the first recorded lyrics are prevalent everywhere. However, previously the worldview of Belarusian folk song lyrics was not the subject of research. Therefore, the aim of the article is to show the unique and specific worldview of these songs.
\end{abstract}

Keywords: Belarusian folklore, Belarusian folk songs lyrics, worldview

\section{INTRODUCTION}

Belarusian folk song lyrics are a large part of Belarusian folklore. In contrast to the ritual songs which are functionally related to agriculturists' work throughout the year, and the basic stages of human life (birth, marriage, and death), folk song lyrics reflect the social aspects of human existence. They include love, family, social, and humorous songs. Their characteristic features are:

- Absence of connecting to a certain rite stage. The main task of the lyrical songs is to express feelings, attitudes to certain phenomena of reality in contrast to the sacral-magical and utilitarian functionality with regard to ceremonial poetry. In folk song lyrics "the expression of feelings and personal experiences isn't limited" (Mažejka 2008: 122);

- Variability in Belarusian folk song lyrics;

- The special musical character of folk song lyrics in comparison to ceremonial lyrics, as well as other lyrical genres;

- The predominance of the ideological and emotional component over the narrative: the human being is interpreted in the light of experiences and feelings, and the main attention is focused on the discovery of the inner world, 
the transmission of psychological states, thoughts, etc. In the center of the song, as Hurski has shown, "it is always a person (lyrical hero or heroine), personal destiny, thoughts, feelings and experiences arising from both subjective features of the relationship with relatives... and the circumstances of the social environment, public life" (Hurski 2002: 3);

- Commonality of poetic principles and methods of the songs' textual organization.

Lyrics describe the most important stages of human life: the adolescent years or a period of family life as well as the lives of individual population groups. Lyrical heroes are divided according to their social status, sexual age (woman, man), family (husband, wife, mother, father, mother-in-law, etc.) and professional status (Cossack, soldier, Chumak, Burlak, etc.). These songs do not create a complex psychological image and represent only the most general, stereotypical mental states in particular (and typical) situations.

Today Belarusian folk song lyrics persist as one of the most widespread genres of Belarusian folklore. They are well represented in printed editions of folklore of the nineteenth-twenty-first centuries. Collecting and publishing the songs started in the 1840s. There are the following stages: 1 ) from the 1840 s to the $1920 \mathrm{~s} ; 2$ ) from the 1920 s to the $1970 \mathrm{~s} ; 3$ ) from the 1970 s to the beginning of the twenty-first century.

The period between the 1840s and 1920s is characterized by initial collecting, processing, and publication of works of different folklore genres. The largest collection of folk song lyrics is contained in the collections of Czeczot (1844, 1846), Tyszkiewicz (1871), Gil'tebrant (1866), Shein (1873, 1874), Radchenko (1888), Romanov (1886), Dobrovol'skiy (1903), Bulgakovskiy (1890), Harecki and Jahoraŭ (1928), and others. Also Belarusian folk songs came to the attention of foreign - Polish (Federowski 1958, 1960, 1969; Kolberg 1968) and Czech (Kuba 1887) - researchers in this period.

From the 1920 s to the 1970 s, the situation changed significantly. The research focus moved mainly to "contemporary folklore", which reflected the October Revolution, class struggle, collectivization, and other processes, but in the collections of Šyrma (1959, 1960), Sacharaŭ (1940), Hilievič (1976), Čurkin (1949), and Citovič $(1959,1975)$ considerable attention was paid to Belarusian folk song lyrics.

The next period is characterized by the publication of the thematic series (multivolume edition Belarusian Folk Art, the volumes of which, titled Love Songs (Fiadosik 1978), Family Songs (Fiadosik 1984), and Social Songs (Fiadosik 1987) are dedicated to folk song lyrics), and regional collections of Belarusian folklore (the multi-volume edition Traditional Artistic Culture of the 
Belarusian People in six volumes (Varfalamiejeva 2001-2013), and others, which show the richness and local specificity of folklore.

Theoretical studies of Belarusian folk songs were started by Karskiy (2007 [1916]: 243-259). He identified the main themes; revealed the semantics of some images; discovered the specifics of rhythmic and melodic patterns, rhymes and stanzas; and revealed correlations with songs of other Slavic nations. Some conclusions are subjective but, nevertheless, his study is the first attempt to systematically study the main Belarusian folklore genres.

Further study of poetry continued in the 1960s mainly in literary folkloristics. The problems that were considered related to classification; genesis; ideological and thematic content; poetics; comparative analysis of the folk songs of Slavonic peoples; rhythmic and melodic structure; moral, ethical and aesthetic aspects; folklore and literary interaction, and historiography (Hilievič 1968, 1975; Hliebka 1975; Hrynblat 1967, etc.).

At the beginning of the twenty-first century, focus was given to textual complexes not of genre relations, but as a complicated system of codes. The dendrological and coloristic codes were systematically described by Švied (2006, 2011a). Also landscape-topographical, astronomical, animalistic, and somatic codes were described to a certain extent. When studying these codes in varying degrees, Belarusian folk song lyrics were used.

Like every folk genre, Belarusian folk song lyrics create a unique and specific worldview, ${ }^{1}$ the study of which opens up prospects for the description of the general folk worldview.

\section{METHODS OF RESEARCH AND SOURCES}

Study of worldview is carried out through a thesaurus description of its units (keywords), based on the model of thesaurus description of folk poetry language, which was offered by Serafima Nikitina. Keywords are determined by the frequency of use, word-forming capabilities, involvement of the words in idioms/formulas, and additional cultural or semantic loading. With the help of the model, fixed semantic connections of keywords in the text are made, which further allows the location of each individual image in the worldview to be determined (1993).

Keywords are characterized by the following functions (semantic relations): synonyms; isofunctional words; antonyms; hyponyms - hypernyms; plurality - the main element of plurality; part - whole; object - internal attribute; object - external attribute; measure, number, amount; object/action - locus; 
subject - action; addressee - the action; object - the action; instrument - the action; implication; metamorphosis; associative complex, and individual functions. Nikitina says that they "provide an opportunity to see how deep and diverse are connections of the title unit with other words and expressions of folklore language on the number of completed items/functions and the number of words and phrases in these points" (Nikitina 2006: 75).

Quantitative analysis revealed the most frequent images of Belarusian folk song lyrics. It was carried out on the basis of the book The Lyric Songs by Hilievič (1976), which includes love, family, social, and humorous songs (I have not taken into account songs for dances and ditties). The selection is based on the high scientific level of publication and a sufficient number of well-preserved songs, recorded within the same time period.

The empirical basis for the description of the keywords was also constituted by the following collections: Love Songs (Fiadosik 1978), Family Songs (Fiadosik 1984), Social Songs (Fiadosik 1987), Belarusian Folk Songs (Šyrma 1959, 1960), and others.

The reasons for preferring printed sources to analyze folk songs is that the most complete of them are based on the materials of the largest and oldest folklore archive of Belarus - the Collection of Folklore Recordings, which is stored at the Center for Belarusian Culture, Language and Literature Research of the National Academy of Sciences of Belarus. The collection includes materials of field expeditions of the institute (since 2012 it has been called the Center for Belarusian Culture, Language and Literature Research) staff (1960-2016); manuscripts which were submitted to the Best Folklore Collector contest; materials from archives of Belarusian universities, and from private archives donated by writers, cultural figures, researchers, etc. So printed editions contain the most complete collections of all types of Belarusian folk song lyrics based on the diversity of themes and variations.

\section{WORLDVIEW: STRUCTURE AND SEMANTICS OF ELEMENTS}

In Belarusian folk song lyrics, the world consists of heaven and earth, referring to a vertical orientation, but at the same time the east-west axis is important (the Belarusian folk model focuses on the motion of the sun).

The heaven in the songs is the "mirror" of what is happening on the ground. We can learn/hear from the song about the most important, significant events. In a small group of songs heaven appears as God's location. Also, astronomical objects are located there: the sun, the moon, stars. 
The semantics of the astronomical images are associated with the sphere of family relations - they embody the characteristics of songs: sun - a mother, a young woman, a father, the old man; moon - a father; star - a daughter, a mother, a sister. The time of day is encoded in astronomical images. Sunset (expressions such as the sun set, the sun is low), the rising of the moon and stars, and the appearance of stars in the sky indicate the occurrence of the dark time of the day - evening, night. Sunrise or dawn indicates the onset of the morning. Sunlight is associated with daytime.

In the Belarusian folk songs, the sun is the most semiotically loaded image among the astronomical objects. Its location is characterized by remoteness (behind a pinery, on the hill, over the hill, behind an oak forest). The main activities related to the image of the sun can be divided into several groups: movement (to roll, to go, to rise), the impact on the result (to heat, to dry, to burn $u p$ ), the location in reference to the object (to sit in front of, to stand in front of) and other activities (to stitch, to look at). The main epithet hot accentuates natural characteristics; the attributes bright or clear emphasize belonging to the sphere of the Sacred.

The ideal situation is often modeled by using an image of the sun, and the lexeme opens an associative sequence, beginning with the description: Sonca hreić, viecier vieić, žyta palavieić... (The sun is heating, the wind is blowing, the rye is maturing...) (Hilievič 1976: 127). Violation of the order points out a problem, an "irregular" situation. The solution of the problem constitutes the storyline situation of the song. In the state of disease, age-old order is perceived as negative, bringing suffering.

Astronomical objects (moon, stars) in Belarusian folk song lyrics are in the active position: they are the subjects of the action. The main activities related to the images of the moon and stars can be divided into two groups - directional movement and lighting.

In the songs the earth is the epitome of femininity (expressions such as earthmother): "Moj milieńki zvalicca, Ab ziamliu udarycca: Ni mnie, ni tavaryšcy Syroj ziamli-matušcy" (My dear young man fell down, hitting the ground, do not get me or a friend, but the damp earth-mother...) (Hilievič 1976: 136). The associative complex damp land-yellow sand reflects the semantics of the burial place, the grave: “Žoŭcieńki piasok, syraja ziamlia, Tut pachavana milaja maja” (Yellow sand, damp earth - here my dear is buried) (Hilievič 1976: 106).

Heaven and earth form the world - a space which is inhabited by people. The adverbs all and whole point out the finiteness of the world. This also indirectly indicates the following situation: “-Zakružylasia haloŭka, Sercajka balici. Oj, nie znaju, nie viedaju, Jak mnie pieražyci. - Čym ciabie liačyć, dačuška, I dzie 
ciabie dzieci? - Oj, nie nojdzieš mnie liakarstva, Mamačka, na sviecie” (- Head spun, Heart hurts. Oh, I do not know, I do not know how I can survive. - How should I treat you, daughter? Where should I put you? - Oh, you do not find a cure, Mommy, in the world) (Hilievič 1976: 116). Most often the lexeme world is an object (to pass, to not let go, to find, to give birth, to light, etc.) but may also be the subject of an action (to come, to (already) change, to go, etc.). This change in the age-old world order has a clear negative connotation: "Jaki ž ciapier sviet nastaŭ, To šče nie byvala: HIabje žonka mužyčeńku..." (What in the world is going on now? This has never happened before: the wife has hit her husband...) (Hilievič 1976: 320).

Motifs of birth and meeting the destiny as a result of an unhappy marriage, departure to military service, and parting connect with the lexeme. They are also used in contexts when it comes to wanting to die: "Ja ciabie, niaviestka, nie vady slala, Ja ciabie, niaviestka, z svietu zbaŭliala" (I haven't sent you, daughter-inlaw, for the water, but I wished you, daughter-in-law, to die) (Hilievič 1976: 203).

In Belarusian folk song lyrics, the following calendar-chronological images are represented: time of day (morning, afternoon, evening, night), day of the week (Monday, Tuesday, Wednesday, Thursday, Friday, Saturday, Sunday), seasons (winter, spring, summer) and lexemes (today, yesterday, tomorrow).

In Belarusian folk song lyrics morning begins the day and is a period of activity, working on the farm:

U paniadzielak ranicoj Kasiŭ baćka siena.

Kasiŭ baćka, kasiŭ ja-Kasili my dvoje.

U aŭtorak ranicoj Sušyŭ baćka siena.

Sušyŭ baćka, sušyŭ ja-Sušyli my dvoje.

U sieradu ranicoj Zhrabaŭ baćka siena.

Zhrabaŭ baćka, zhrabaŭ ja - Zhrabali my dvoje.

Ranicoju u čacvier Vaziŭ baćka siena.

Vaziŭ baćka, vaziŭ ja - Vazili my dvoje.

U piatnicu ranicoj Pradaŭ baćka siena.

Pradaŭ baćka, pradaŭ ja - Pradali my dvoje.

U subotu ranicoj Prapiŭ baćka hrošy.

Prapiŭ baćka, prapiŭ ja - Prapili my dvoje.

U niadzieliu uvieś dzień Plakaŭ moj baćka.

Plakaŭ baćka, plakaŭ ja - Plakali my dvoje.

(Hilievič 1976: 298)

Monday morning Father mowed hay.

I mowed, my father mowed - mowed the two of us.

Tuesday morning Father dried hay. 
I dried, Father dried - dried the two of us.

Wednesday morning Father raked hay.

Father raked, I raked - raked the two of us.

Thursday morning Father transported hay.

Father transported, I transported - the two of us transported.

Friday morning Father sold the hay.

Father sold, I sold - sold the two of us.

Saturday morning Father drank the money away.

Father drank away, I drank away - the two of us drank away.

Sunday all day my father cried.

Father cried, I cried - cried the two of us.

The emergence of dew, the sunrise, the dawn, and the crowing of the rooster point to the onset of the morning. The nightingale is an animalistic equivalent of the morning. That is why it is characterized by the epithet early: "Salaviej, salaviej, Ptaška ranniaja, A papiej, salaviej, Piesni raznyja" (Nightingale, nightingale, early birdie, sing, nightingale, different songs) (Hilievič 1976: 270).

In Belarusian folk song lyrics Sunday morning received the greatest semiotic load: that time is central to the development of the plot - the lyrical hero dies: "Pamior, pamior pa Ǔkrainie Kazak maladzieńki. Oj, jon pamior, oj, jon pamior, U niadzieliu rankam, Oj, prybrali, nalažyli Ǔ sviaciolcy na laŭku" (The young Cossack died, died in Ukraine. Oh, he's dead, oh, he died on Sunday morning, oh, remove him, put him on the bench in the upper room) (Hilievič 1976: 78).

The lexeme day is used in two senses: "daytime / the period between sunrise and sunset" or "the day as a whole". In the first meaning the lexeme is characterized by the epithet white. Day is a period of time for agricultural and household work. In Belarusian folk song lyrics, day is the subject (to start, etc.) and object (to sleep, etc.) of actions.

In the meaning "day as a whole" the lexeme is combined with numbers one, two, three:

Siarod horada slučylasia biada:

Zabaliela ǔ čumačeńki halava.

Liažyć čumak dzień, liažyć i druhi-

Nichto jaho nie spytaje, čym ža jon balion.

Naviedaŭ jaho tavaryš jaho.

(Hilievič 1976: 43-44)

In the city disaster happened:

The Chumak has a headache.

The Chumak lies one day, and the second -

No one asks whether he was ill. 
It shows that the lexeme is often a unit of measurement (to walk, to do, to cry, to lie, to drink, etc. a day).

The lexeme day is opposed to night - the period from sunset to sunrise, the dark time of the day, accompanied by the appropriate attributes - late, dark, invisible. During this time agricultural and household work should be completed: people reap or work until nightfall. In the song lyrics night stands for a period of time that needs to be waited for. Night, as Valodzina says (2011: 330 ), is a dangerous time, "associated with the activity of the representatives of the other world of all ranks and grades". For example:

Bylo ŭ matki dzieviać synoŭ, Mother had nine sons,

Dačka malada-dziesiataja. a young daughter - the tenth.

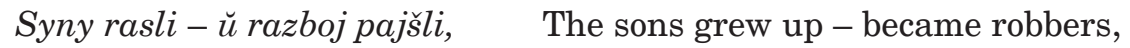

Dačka rasla - zamuž pajšla the daughter grew up -

Za kupčyka-malajca. got married to a merchant.

Jon pajechaŭ kupcavać, He went to trade, A jaje kinuŭ šynkavać. left her to sell vodka. Jechaŭ polie i druhoje, Na treciaje uzjazdžaje Jaho nočka sustrakaje. He went to the first field and the second, enters the third night falls.

Pryviazaŭ kania k biarozie, He tied his horse to a birch,

Sam lioh spać na vozie. he went to sleep on the cart.

Adkul bralisia razbojniki: Jany jaho dy j zabili, Pad kalodu padkacili, Jaho zolata zabrali, Sami sieli j pajechali. (Hilievič 1976: 288) The robbers appeared from nowhere: they killed him and put him under the wood block, took away his gold, sat down and drove away.

The lexeme night is also often combined with the epithets summer and small. In this context, the emphasis is on its short duration: "Lietnia nočka malieńka Ja nie vyspalasia. A ja dnia ǔkaraču, Lietniu ijučku nadtaču" (The summer has a small night - I haven't slept. I will shorten the day, I will lengthen the summer night) (Hilievič 1976: 158).

The sunset designates nightfall:

Jarka sonca zakacilasia, The bright sun had set, Matka ǔ dački zahascilasia. the daughter stayed at Mommy's home for a long time. 
'Oj, praviadu svaju mamačku Za try liasy, za try ciomnyja. Za try liasy, za try ciomnyja, Za try haiki zialionyja.'

Nazad matka ahlianulasia:

Niešta dačka spatyknulasia.

'Ci travička nožki sputala,

Ci rasička vočki vyjela?’

'A sputala dy mnie nožački

Usio čužaja dy staronačka.

A vyjela dy mnie vočački

Usio lichaja dy sviakruchnačka.'
'Oh, I would have seen off my mommy for three forests, three dark forests, three green forests, three dark forests, three green groves.'

After that Mom looked back the daughter stumbled. 'Had grass confused my legs or dew eaten out my eyes?' 'Alien land ate my feet. My wicked mother-in-law

(Hilievič 1976: 249)

In general, leaving the road in the middle of the night (expressions such as to go against), a period which does not provide for activity, does not predict anything good but leads to undesirable consequences: "Nie jedź, braciejka, Nia jedź, rodnieńki, Proci ciomnaje nočy: Ty sam nie chrabry, Tvoj koń nie ŭbrany, Budzieš ty asmiajany" (Don't go, my brother, don't go, my dear, against the dark night: you aren't brave, your horse isn't harnessed, you will be ridiculed) (Hilievič 1976: 145). In the texts the lexeme night is also a unit to measure time (to walk, to [not] sleep, to talk, to sit a night). The associative complex day - night represents "constant" and "permanent": "Oj, u poli jeĺ zialionaja, U niaviestki sviakroŭ šalionaja. Žuryla maladu jak dzień, tak noč, Prahaniala ad siabie proč" (Oh, green fir stands in the field, daughter-in-law has made mother-in-law angry. She scolds the young girl all day and night and banishes her) (Hilievič 1976: 286).

Widespread elements of songs are all the days of the week:

U paniadzielak spliu, spliu,

U aŭtorak snapoŭ sorak

Pšaničački žnu, žnu.

U sieradu vazila,

U čacvier malacila,

U piatnicu viejala,

U subotu mierala, A ŭ niadzieliu pradala

I $z$ chlopcami prapila.

(Hilievič 1976: 318)
On Monday, I slept, I slept.

On Tuesday forty sheaves of wheat I reaped, I reaped.

On Wednesday I drove.

On Thursday I threshed.

On Friday I winnowed.

On Saturday - took measurements, and on Sunday I sold and drank away money with the guys. 
This example points out that the days from Monday to Saturday suggested active work (agricultural and household), and Sunday was intended for rest. The lexeme Monday forms an associative complex with Tuesday. The lexeme Sunday is the most frequent and most semiotically loaded calendar-chronological image. It is used in two senses: "day of the week" and "week in general". As a day of the week, it is characterized by the epithet holy. Symbolic, momentous events happen on this day: the birth of a child, marriage, departure to military service, burial, the drowning of a child, and meeting with God. The lexeme Sunday often forms an associative complex with Saturday.

In Belarusian folk song lyrics, key events take place from Saturday to Sunday. For example, the stepmother becomes ill and sends the orphan to the forest to pick berries:

Z subotki na niadzieĺku Mačycha zachvarela, Mačycha zachvarela, Jahadak zachaciela.

Vypravila sirotku U syr-bor pa jahodku.

Užo na dvare abide - Sirotački z jahad niet.

Na dvare viečareić - U tatački duša mlieić.

'Kab jana ŭtapilasia - Usie ravy papaŭnieli b,

Kab jaje vaŭki zjeli - Usio polie skryvavili b.'

(Hilievič 1976: 29)

From Saturday to Sunday Stepmother was ill,

Stepmother was ill and wanted some berries.

She sent the orphan to the damp pinery to pick berries.

There isn't an orphan in the yard at lunchtime.

The courtyard got dark - Daddy's soul thrilled.

If she drowned herself - all the ditches would have filled with water,

if wolves ate her - fields would be full of blood.

The road to the forest to pick berries correlates with a distant and dangerous road to the alien world and does not provide a happy solution.

The lexeme week represents the semantics of a "sufficient" period of time for meeting with relatives - parents/wife. Its duration and adequacy is stressed by the use of the epithet whole.

The lexemes yesterday, today, and tomorrow are often used as part of associative complexes. On the one hand, such complexes represent duration, frequency, a long period. For example, the lyrical heroine concludes that "the young man has forgotten her" if he did not visit her yesterday or today. On the other hand, such lexemes are in opposition: "Oj, ja ǔčora byla pjana, A siahonnia pachmialilasia. Učora z mužam byla dobra, A siahonnia pasvarylasia” (Oh, I was drunk 
yesterday, and now I have a hangover. Yesterday my husband and I were well, and now we quarreled) (Hilievič 1976: 263) or:

- Siahonnia ja z vami,

A zaŭtra pajedu.

Budziěs, mila, pryliahaci

Až da majho sliedu.

- Ni ja pryliahala,

Pryliahać nie budu.

Žyla, milieńki, z taboju,

I biez ciabie budu.

(Hilievič 1976: 109)
- Today I am with you, and tomorrow I will go.

You, my dear, will lie down on my footprint.

- I didn't lie down,

I wouldn't lie down.

I lived, my dear, with you,

and I will live without you.

Often, use of such associative complexes (yesterday - today, today - tomorrow) points to departure, a parting.

Separately, not as a part of an associative complex, these lexemes are used for a specific interval of time that is important for the development of the story. The lexeme tomorrow is used for the nearest future. Tomorrow (Sunday) is a momentous event for the heroine - the wedding.

Space is presented in the natural (field, river, forest, meadow, sea, valley, beach, mountain, wellspring, the Danube, grove, oak groves, etc.) and cultural (garden, road, window, house, yard, inn, gate, grave, storage room, porch, door, bridge, Ukraine, Crimea, etc.) objects. In Belarusian folk song lyrics, they perform a number of typological features - they mark the place of action, semantically reflect a center where emblematic events happen and are related to our own or the alien world; they indicate the boundary locus.

The image of garden semantically reflects "our" space; images of Ukraine and Crimea are "alien". Characteristics of the frontier are shown in grove, road, tree, forest, sea, bridge, the river, the Danube, etc.; the same semantics are found in associative complexes of the type three forests, three dark forests, three green pineries, three wide fields, three deep seas, three forests, dark forests, three green gardens, etc.

The image of field is the most semiotically loaded natural object. Synonyms of the lexeme field as space-treated, cultivated territory are cornfield and garden; and its antonyms are forest and mountain (opposed to the field in a vertically situated hierarchy). The specific epithets wide, flat, gold, moneyed, clear, deserted, stony, sandy, and barren indicate the ambivalence of the image. Actions related to agricultural activities and land processing (to plow, to reap, to sow, to harrow, to weed, to grind, etc.) characterize the field as an assimilated, ennobled space. This image is associated with lovers' meeting (the verbs to walk, to fall in love, to hug), a soldier's death, meeting with personalized death, loss 
of virginity, or searching for a happy destiny. In Belarusian folk song lyrics field is also a measure of distance.

In the songs forest, grove, and pinery, which are contextually synonymous in meaning with "the natural locus", are outside the cultural space and relate to such motifs as checking the moral qualities of the girl and loss of virginity:

Dziaǔčynačka pa baru chadzila, The girl went to the forest, maladaja ŭ baru zabludzila. she got lost in the forest.

Prybludzila k zialionamu dubu; She came to the green oak.

- Vot ja tut ža načavać budu. - So I would spend the night there.

Ja dumala, što dub zielianieńki, I thought that it was a green oak ažno ž heta kazak maladzieńki. but it was a young Cossack.

- Vot vaźmu ja harelki paŭkvarty, - - I would take half of a bottle of vodka zaprabuju $\breve{u}$ dziaǔčynački praŭdy. and ask the girl to tell the truth.

- Vaźmi sabie kvarcinu, druhuju, - Take a bottle, and a second, nie abmanieš mianie, maladuju. $\quad$ you will not deceive me, young one.

Jak uziaŭ dziaǔčynu za bieluju ručku, He took her white hand zavioŭ dziaŭčynu pad bielu biarozu, and deceived a girl under the white birch, zavioŭ dziaŭčynu pad bielu biarozu, deceived a girl under the white birch, tam abmanuŭ nie pjanu, cviarozu. deceived a sober girl.

(Fiadosik 1978: № 362b)

In the context, the motif of drinking alcohol (vodka) is actualized, and it is connected with the loss of virginity, an unhappy fate, and meetings and marriage.

News about conscription comes out of the forest:

Oj, z-pad liesu, liesu ciomnaha, z-pad javara z-pad zialionaha vyliatala chiža ptašačka, vynasila hasudarski prykaz.

Čutno-vidno, buduć nabor nabirać, katoraha nam synočka addać...

(Fiadosik 1987: № 12)

$\mathrm{Oh}$, out of the forest, dark forest, from the green sycamore a bird of prey flew, brought the king's orders.

I have heard, I have seen they would send someone to recruit, which son should we give to recruit...

It is distinctive that this news is brought by birds (bird of paradise, gray bird, etc.), which are mediators between "our own" and the "alien" world.

In Belarusian folk song lyrics, the valley is a low-lying area and the opposite of the mountain. In the valley grass, viburnum, people, a girl, a Cossack 
(deceased), two injured young men, a horse, a grave, and personalized death are located. Typical actions that take place in the valley - to bury, to freeze, to go astray, to lie (the body), to sit (personalized death), to go, to meet, to walk, to run - emphasize the link of the locus with the "alien" world: "Tvajho muža, tvajho muža na halovačkach niasuć, scharanili, scharanili pry šyrokaj dalinie" (They carry your husband, your husband on the heads, bury, bury him in the wide valley) (Fiadosik 1987: № 282). As we can see from the last example, the image of valley in songs is semantically akin to a burial place. Duchits and Lobač emphasize that "in a broader sense valley as a low-lying land is correlated in people's views with the grave" (2011: 139-140). Naturally, in this context it is the location of personalized death: "A pajdu ja luham-dalinaju, siadzić smierć pad kalinaju" (And I will go to the meadow-valley, death sits under the viburnum) (Fiadosik 1984: № 197). The center where key events happen is the mountain. In Belarusian folk song lyrics, such natural objects as a mountain, a river, the Danube, and the wellspring are associated primarily with the motif of meeting, the courting of lovers.

Among cultural objects the most semiotically loaded images are garden, road, yard, and house, and their component parts (window, door, pantry, porch, etc.). The image of the garden represents a native house or family, which marries off a girl: "A ŭ sadzie, sadzie ziaziulia kukavala, pa mnie, maladoj, matulia biedavala. - Pakiń, pierastań, ziaziulia, kukavaci, pakiń, pierastań, matulia, biedavaci. Pakiń, pierastań, matulia, biedavaci - ja navučylasia, jak hora haravaci" (And in the garden, in the garden the cuckoo cuckooed. For me, a young girl, Mom is missing. - Stop it, stop it, cuckoo. Stop it, stop it, Mom. Stop it, stop it, Mom - I've known sorrow) (Fiadosik 1984: № 479). Often, a married woman turns into a bird and flies to the native garden to her parents for a piece of advice. In the garden the cuckoo, nightingale, bird, girl, Cossack, father and mother, my brother and sister, flowers, cherries, apples, and grapes are located. The main epithets that characterize the image of the garden are green and cherry, emphasizing positive aspects of this locus. As rightly pointed out by Šved (2011: 197-198), "the permanent epithet green ... has sustained a positive, life-affirming semantics and is perceived not as the color but condition of the tree". Meetings and secret conversations are related to the image of the garden. This image has some characteristics of the alien world: here are located the viburnum or the grave; it is also a part of the associative complex field - the sea-forest-garden, which refers to the spatial borderland.

The image of road has the most distinct characteristics of the borderland in songs. The lexeme road is synonymous to path, track or trail-track. The opposite to road (on the basis of flat/bumpy) is a bumpy track and on the basis of cultivated/natural - harvested cropfield. 
The lexeme road is often the subject of action: knocking, eating, and moaning indicate the dynamic characteristic of the image. However, it can also be the object of the action: to ask for, to go to, to know, to shorten, to glance at, to wait for, etc. But more often it is the place in which certain actions occur: to go on, to keep on, to grow over (grass, birch, oak, aspen), to hang (green viburnum), to go on, to cover up, to plow, to bury on, to roll, (not) to stray from, to find, to tire, to water, to bring to, to throw on, to look for, to come, to spend the night in, to run along.

All characters in the songs are connected with this image: for the girl it is a road to marriage, to the husband's family, to a foster home; for the man it is a road to a foreign land, to Ukraine, to Odessa; for the married woman it is a road to her parental home; for the husband - to Ukraine, to war; for the recruit - to military service; for soldiers (Cossacks, Hussars) - to war, to an alien world; for the Chumak - to Crimea. The road has a fateful role and emphasizes an intermediate state for the characters that stay on it. For example, the behavior of the horse on the road predicts the future fate of its owner:

Vypraŭliala maci syna

U balyšuju darohu.

- Jedź, jedź, moj synočak,

Dy nazad viarnisia.

- A boh znaje, boh viedaje,

Nazad ci viarnusia:

Siarod dvara šyrokaha

Moj koń spatyknuŭsia. [...]

- Kali, kali, moj synočak,

Pryjdzie ka mnie ŭ hosci?

- Tady, tady, maja mamka,

Pryjdu k tabie ŭ hosci,

Jak vyrascie travičačka

$\mathrm{Na}$ novym pamoscie.

Rasla, rasla travičačka

- Stala pasychaci.

Stala jaho mamka časta

Syna ŭspaminaci.

Liacieŭ piatuch cieraz reku,

Kryknuŭ ku-ka-re-ku.

Nie ŭvidziela maci syna,

Nie üvidzić davieku.

(Hilievič 1976: 64-65)
Mother sent her son

on a long journey.

- Go, go, my son,

and come back.

- Only God knows, God knows, if I will come back or not:

in the wide courtyard

my horse stumbled [...]

- When, when, my son,

will you come to visit me?

- My mother,

I'll come to you to visit

when the grass grows

on the new ground.

The grass grew and grew

- and became dry.

Mother recalls

her son every day.

The rooster flew over the river, called 'Ku-ka-re-ku'.

You have not seen, Mother, your son, you haven't seen him. 
Transfer to a distant country, a foreign land is a "great" way, which can be correlated with the path to the other world. Parental instruction precedes the departure. In Belarusian folk song lyrics, the image of the road is tragic, permeated by feelings of bitterness and despair, indicated by the epithets steep, broken, not passing, littered, bad, broken by stone, drenched with tears, soldier, knocking, stony, wide, smooth, brotherly.

The image of the road is semantically related to the place where events happen: "Prajšoŭ ja sviet, Ukrainu - Nie vidzieŭ dziva nad kalinu, Što ŭ luzie pry darozie staić: Na jej vieciejki biez vietru šumiać, Na jej jahadki biez sonca spiejuć, Na jej rasica biez doždžu staić" (I travelled all the world and Ukraine and didn't see such a miracle as the viburnum that stands in the meadow on the roadside: its branches make sound without wind, its berries ripen without the sun, there is dew without rain) (Hilievič 1976: 286); or an interval, connecting the points of the space: "Biažy, kosiu, darohaju, Biažy, kosiu, šyrokaju - Na try stupy stupajučy, Svajho domu šukajučy” (Run, horse, along the road, by the wide path, and there will be an old house) (Hilievič 1976: 74). Also this image semantically represents a "way of life", personal destiny, or fate.

The time of day in which the character walks is very important: the road at nighttime is perceived as very dangerous because it is the period of activity of evil forces. Lobač emphasizes that "one and the same road is not equal in the daytime and at night, in the field, forest, swamp, near the temple, cemetery, and inn, and especially in nodal points of its deployment - on the bridge, causeway or at a crossroads" (2013: 322).

The lexeme is characterized by compatibility with the numbers two and three. Overgrowing, sweeping, and covering the road symbolize obstacles that the hero cannot overcome:

- Jak mnie, braciejko, jak mnie, rodnieńki,

U hasciach ŭ vas byvaci?

Pazarastali sciežki-darožki

- Nie mahu prataptaci.

- Najmi, siastryca, najmi, rodnieńka,

Skrypki, cymbaly,

Kab prataptali sciežki-darožki

Da zialionaha haju.

(Hilievič 1976: 20)

- How can I, my brother, how can I, my dear, visit you?

The path-track grows over, I can't trample.

- Hire, sister, hire, my dear, a violin,

a dulcimer to trample the road to the green grove. 
The expression to throw the road means to prevent, stop an action:

- Zdrada, zdrada, čornieńkija broŭcy,

Oj, niavierny milieńkaha sloŭcy.

Jak liubiŭsia - žanicca maniŭsia,

A ciapier jon mianie pakidaić,

$Z$ nočy-poŭnačy kaniu abrok dajeć,

Rana-ranieńka $z$ dvoru vyjazdžaić.

- Nie jedź, nie jedź, moj milieńki,

liesam Pazakidaju darohu vierasam.

Nie jedź, nie jedź, moj milieńki boram

- Pazakidaju darohu javoram.

(Hilievič 1976: 112)

- Treason, dark eyebrows, treason, my dear, your words were untrue. When he loved me

- he deceived to marry, and now he leaves me alone at night.

He gives oats to the horse early in the morning and leaves the yard.

- Don't go, don't go, my dear, by the forest road,

I will throw the road by heather.

Don't go, don't go, my dear, by the forest road

- I throw the road by sycamore.

The image of bridge is semantically connected to the location of the boundary. The expression going over the bridge has gained the metaphorical meaning of losing virginity.

The center of a cultivated area is a house, where the main characters (girl, wife, mother, daughter, stepmother, husband, drunkards, children, boyfriend, oat and rye bread) are located. In lyrical songs the house is a part of the yard, but it includes the smaller parts such as the window, door, and porch; there are also outbuildings - a barn and others. The lexeme house is semantically related to a safe locus, acts as a resting place, and is in constant contact with the holidays: "Da ja ž doma byvala, Časta piva pivala. Siastra pje, z rotu ĺje, Bratka pje - z kania mlieje, Jak napiŭsia, dyk zvaliŭsia" (And I visited home and often drank a lot of beer. Sister drank, beer poured out of her mouth. Brother drank, the horse was thrilled, he drank and fell from the horse) (Hilievič 1976: 173).

The house as a safe locus is opposed to danger - war: "- Tabie, synočak, tabie: Ty ž na vajnu pajedziš, A nas doma pakiniš. - Nie plač, mamka, pry mnie, Naplačyšsia biez mianie. Naplačyšsia davoli, Jak nie ǔvidziš nikoli” (You, my son, you: You will go to war and leave us at home. - Do not cry, my dear mom, when I'm here, you will cry without me, you will cry enough, when you would 
have ever seen me) (Hilievič 1976: 60). Staying at home is opposed to freedom and festivities that are associated with a violation of social norms (loss of virginity outside of marriage), and, in the end, lead to undesirable consequences. The image of a house is also opposed to the surrounding world. In combination with the attributes eternal, cramped, and dark the lexeme house acquires the opposite meaning - a coffin, is characterized by the absence of the typical features (windows, doors), and is located opposite to the sun: "A kali ž dy pamru Staliaročkaŭ ja syšču, Jalinu rubać skažu. Buduć jalinu rubać, Viečny dom budavać - Biez dzviarej, biez akonca, Proci jasnaha sonca" (And when I will die, and I will find woodworkers, I will tell them to cut down the spruce. They will cut down the spruce to build the eternal house - without doors, without windows, against the bright sun) (Hilievič 1976: 74).

The expression state house means prison. In this meaning it acts as a synonym to the lexeme captivity. Staying in a state building relates to an unhappy fate. Often images of a young man or husband are linked with absence and leaving home (the opposite of home is a distant world). Life in a husband's family that is located far away (beyond the Danube) is in opposition to the native home: "Za Dunajem staić chatačka, A tam žyvie maja matačka, Oj, tam žyvie maja rodnaja. Ja ad mamački adlučylasia, Da sviakroǔki prylučylasia" (Behind the Danube my home is and there my mother lives, oh, there my dear lives. I left Mom and joined mother-in-law) (Hilievič 1976: 213).

The aim of banishment from home is to get rid of the character. Lobač emphasizes that "the forced removal (banishment) from the house of one of the family (especially parents who embodied the continuity between generations) leads to tragic consequences for the whole family" (2013: 289): “A ŭ poli krapiŭka žyžlivaja, Ǔ niaviechny sviakroǔka žurlivaja. Žuryla niaviechnu jak dzień, dyk noč, Vyhnala niaviechnu z domu proč: - Idzi, niaviechna, u čysta polie, A stań ža ty tam rabinaju, Rabinkaju zielianieńkaju" (Stinging nettle is in the field, the daughter-in-law has a sad mother-in-law. She screams at her daughter day and night, and kicked the daughter out of the house: - Come, daughter, in the open country, stand there, rowan tree, green rowan tree) (Hilievič 1976: 286).

The lexeme house is not a subject of action but, as a rule, it is in a dependent position. The main activities related to the house can be divided into several groups: staying in the house (presence/absence: (not) to stay, to spend the night, (not) to find); meals, drinks (to have dinner, to drink (beer)); rest (to sleep), work (to flail); directional movement (to go with, to expel, to leave); other actions (to happen (trouble), to give birth to, to love, to brew (beer)).

The exterior of the house, according to the lyrics, is a mirror of family life. "Disorder" in its exterior indicates the general situation in the family: 
- Čaho ŭ ciabie, siastryca, chatka niaroŭna?

Čaho ŭ ciabie, siastryca, parohi vysoki?

Čaho ŭ ciabie, siastryca, vadzica dalioka?

- Cišej, braciejka, cišej havary.

Ty ž maju sviakroŭku nie unaravi.

Ty ž maje chatački nie paraŭnuješ,

Ty ž maich parohaŭ nie panižaješ.

Ty ž majoj vadzicy nie nabližaješ,

Ty ž majoj sviakroŭki nie zadobryš.

(Hilievič 1976: 190)

- Why is, sister, your house uneven?

Why does, sister, your house have high thresholds?

Why is, sister, water so far?

- Hush, brother, speak softly.

Don't make my mother-in-law angry!

You won't even my house, you don't put down my thresholds.

You don't bring my water closer,

you aren't to make my mother-in-law kind.

The order, respectively, points at peace and harmony: "Čamu ž mnie nie pieć, Čamu ž nie hudzieć, Kali ǔ majoj chatačcy Paradak idzieć?” (So why shouldn't I sing, shouldn't I buzz, if my house is in order?) (Hilievič 1976: 296).

A component part of the house - the window - receives sufficient semiotic load. The lexeme is semantically the place of communication with the outside world:

Chadzila udovačka u dalinku,

Prakalola nožačku na bylinku.

Padyšla k dzievierku pad akienca.

- Paradź mnie, dzievierka, dzie mnie dziecca?

- Radžu, bratovačka, isci ŭtapicca,

$Z$ malieńkimi dzietkami nie vadzicca.

Pajšla jana k bracietku pad akienca.

- Paradź mnie, bracietka, dzie mnie dziecca?

A radziŭ mnie dzievierka utapicca,

$Z$ malieńkimi dzietkami nie vadzicca.

- Nie tapisia, siastryca, nie tapisia,

Pryjdzi ŭ maju chatačku, prychinisia,

$Z$ malieńkimi dzietkami pavadzisia.

(Hilievič 1976: 26) 
The widow went to the valley, pierced her foot on the grass.

She went to her brother-in-law under the window.

- Give me a piece of advice, brother-in-law, where should I go?

- I advise you, brother's wife, go away and drown, don't stay with small children.

She went to her brother under the window.

- Give me a piece of advice, brother, where should I go?

The brother-in-law advised me to drown, not to stay with small children.

- Don't drown, my sister, don't drown, come to my home, get some rest, and play with small children.

Baiburin (2005 [1983]: 166) noted that windows and doors "are related to the idea of penetration, connecting the house with the outside world, but this connection has a specific character. Windows connect houses not only with the rest of the world, but with the world of cosmic phenomena and processes, such as the sun (moon), the part of the world, the landscape, the alternation of light and darkness, day and night, winter and summer, etc.".

The Ukrainian and Russian toponyms (Ukraine, Crimea, Rus, Moscow) in Belarusian folk songs lyrics, as a rule, semantically represent a foreign country that is characterized by remoteness and an exceptional degree of danger; there a hero expected an unhappy fate, illness, and even death. However, they can be marked neutrally, as the location of the Cossack, soldier, or recruit. Motifs of deception, treason, loss of virginity, and a bastard child are connected with these characters. Metropolises (Kyiv, Lviv, Warsaw, Cracow) are otherwise semantically important: they represent cultural centers and the center of the universe.

A man inhabits the central place in the worldview in Belarusian folk song lyrics. The image of a man, as a rule, is characterized by the emotional and evaluative adjectives lazy and nice. The image is determined not only by the presence of body parts, organs, or fluids (head, eyes, lips, face, hair, eyebrows, arms, hands, feet, blood, flesh, bones), but also by the soul and mind. The lexeme body is usually used when talking about a killed/wounded young man/soldier: "Tam liažyć pad kustom ciela bielaje, ciela bielaje, to saldackaje. Maladzieńki saldat uvieś paranieny, pierad smierciu liažyć, jak plast bielieńki” (There under the bush the white body lies, the white body of the soldier. The young soldier was wounded whole, white before death) (Kabašnikaŭ et al. 1985: 482). The lexeme is accompanied by the epithet white and, depending on the object, is semantically reflective of clean, young, or beautiful (if characterizing female 
characters): “Oj, addavala mianie mamačka, Za kaho ja nie chaciela. Oj, šumić, hudzie da j nahaječka Lia majho bielaha ciela" (Oh, Mom married me to whom I didn't want. Oh, whip noises, buzz near my white body) (Hilievič 1976: 226) or bled white (if related to a soldier/Cossack): "Liažyć ciela, jak dzień, biela, biez ruk, biez noh, biez haloŭki" (Lies the body as day, white, with no arms, no legs, no head) (Šyrma 1960: 300). The epithets killed and soldier (severely wounded soldier) also characterize it as lifeless. Images of body parts are symbols of abstract concepts: head - mind, heart - emotions, face, eyes, and eyebrows beauty, youth. The braid serves as indicator of willingness/unwillingness to marry, shoulders is an object of physical impact. Associative complexes soul body, soul - heart represent the whole person.

A significant part of lyrical songs focus on questions of personal fate. According to the songs, destiny is given to a person in a key moment - at the moment of birth. Mother or God endows a man's personal fate. At the same time Belarusian lyrical songs indicate that fate depends on godfathers. The fate is given by "higher powers" and does not depend on external factors (desires, behavior, appearance, etc.). However, a fairly common plot is that the fate of the person is taken regardless of the will of God: "Što ž ty, matka, što ž ty, matka, narabila, čamu rana nie zbudzila? Usie dzievački, usie dzievački rana ǔstali, ščascie j doliu razabrali. Ja, malada, ja, malada, spaznilasia, ščascia j doli ŭmylilasia” (What did you, Mother, do, why didn't wake up early? All the girls, all the girls got up early, and took good fortune. I was, I was late, and happiness and good fortune didn't receive) (Šyrma 1960: 7). The song emphasizes that personal fate is only a certain portion of overall fate.

In Belarusian folk song lyrics, destiny is not absolute: the turning point is the wedding: “- Z doliaju radzila, z ščasciem hadavala, jak papaŭsia lichi zamuž, navieki prapala" (I gave you birth with good fortune, you grew up with happiness. You married unsuccessfully, and lost happiness forever) (Šyrma 1960: 151). Baiburin explains that "a person receives the fate at the moment of birth, but at the same time in next rituals ... new destiny or rather additional is necessary for a new stage of life" (1993: 122). The conception of good destiny is directly linked to successful marriage, creation of family, mutual love: "Nie tam ščascie, nie tam dolia, dzie bahaty liudzi, a chto biare pa milosci, toj ščaslivy budzie" (There is no happiness, it is no good destiny where rich people are, but who marries for love, that one would be happy) (Fiadosik 1978: 156).

Unfortunate fate is related to a husband's family: "Doliečka lichaja - siamiejka čužaja" (Unfortunate fate - other family) (Šyrma 1960: 60). The fate of married women appears unchanged; it is already impossible to overcome: 
Pajdu da kamory - ani chlieba, ni soli.

Ni ŭciakaci mnie, ni ǔbiažaci mnie ad nieščaslivaj doli.

Pajdu da matuli, na paroh pastupliusia.

Liudzi havorać, ja j sama znaju, što nazad nie viarnusia.

(Šyrma 1960: 30)

I'll go to the pantry - neither bread nor salt.

I can't run, can't run from my unhappy fate.

Go to your mother, tread on the threshold.

People say and I know myself that I'll not come back.

Unhappy destiny is also linked to the absence of family, the inability to marry the loved one, recruiting, service in the army, and inability to earn money. The fate of orphans and widows is shown as particularly unfortunate. The nouns fate and destiny are accompanied by metaphorical epithets: "Oj, horkaja ja i dolia maja, za pjanicu zamuž vyjšla" (Oh, I'm bitter and my fate is bitter, I've married a drunkard) (Kabašnikaŭ et al. 1985: 499). Genetically related to the mythological way of thinking, metaphorical epithets emphasize a particular role of the concept in songs, giving them emotional coloring.

The image of destiny often has anthropomorphic, personalized features:

Oj, viadu biadu, oj, viadu biadu, dy biada nie viadziecca.

A pad višniaju, pad čarešniaju biada spaci kladziecca.

Oj, liažy, biada, dy zasni, biada,

na ŭsiu nočańku spaci,

a ja, molada-maladziusieńka, pajdu mila šukaci.

(Fiadosik 1978: 144)

Oh, I lead trouble, oh, I lead trouble,

but the trouble is not led.

Under a cherry, under a sweet cherry trouble is going to bed.

Oh, lie down, trouble, go to sleep, trouble,

sleep the whole night, and I, a young girl,

am going to look for a loved young man.

It can also be embodied in images of plants (shrubs, flowers, grasses) or any other material object.

A significant place in the image system of Belarusian folk song lyrics is occupied by animalistic images (images of birds, animals, and fish). They represent gender and age affiliation as well as the social status of characters, and present the ideal relationship between two lovers. Images of animals perform mediator functions. In song lyrics images of birds are used to emphasize the 
similarities/differences in age and social status. Images with clear female semantics stand out: the swallow symbolizes a woman of premarital age, a wife, a mother, a sister; the cuckoo - a wife that is missing a husband, a mother that worries about the fate of her daughter in another family, an orphan; the female dove - a girl, woman, or mother. A number of bird images are constantly semantically male: the male dove symbolizes an unmarried male, a brother; the nightingale - a man, Cossack, brother, husband, father-in-law; the falcona successful, clever, brave guy, father, brother, or guest, as well as a destroyer or fighter; geese symbolize young recruits. The daw can act as a female and as a male image. Paired ornithological images symbolize mutual love, faithfulness, sincerity, harmony, mutual respect, and an ideal relationship between two lovers: "Zažyviom my, zapanujem, jak halubkoŭ dvoje, i razdzielim z taboj ščascie, doliu j niadoliu" (We will live, will reign, as two doves, and share with you happiness and unhappiness) (Kabašnikaŭ et al. 1985: 512). Such birds as the cuckoo, pigeon, falcon, and nightingale as well as geese in Belarusian folk song lyrics are messengers between a girl and her native home, parents, and relatives; between lovers; between a soldier of war and his mother or wife: "Pa siastruliečku šliu ziaziuliečku, A pa ciotačku - pierapiolačku, A pa bratačku salavieječku..." (For my sister I send a cuckoo, for my aunt a quail, but for my brother a nightingale...) (Hilievič 1976: 236).

Birds are the inhabitants of the upper circle of the universe, which know and see everything. They report the unhappy fate of the girl in another family and bring news about the death of the young man at war in a foreign land. A frequent motif is a woman turning into a bird - cuckoo: the girl transforms and flies to the parental home or a garden; the mother flies and searches for her son in a foreign land:

- Kab ja byla ziaziulkaju, umiela kuvaci, paliaciela b na Ǔkrainu synočka šukaci.

Paliaciela b na Ukrainu i skazala b:

- Ku-ku! - Padaj, padaj, moj synočku, choć pravuju ruku!

- Oj, rad by ja, maja maci, abiedzvie padaci,

- syra ziamlia, smoĺna doška - ciažańka ŭstaci.

(Šyrma 1959: № 204)

- If I were a cuckoo, I could cuckoo!

I'd fly to Ukraine to look for my son.

I'd fly to Ukraine and would say:

- Cuckoo! - Give, give, my son, to me the right hand!

- Oh, I'm glad to give you, my mother, both,

but - damp land, board in the resin - it's hard to stand up. 
Eremina shows that this motif is a testament to the belief in transformation and conveys to us the remains of mythological thinking. "Mythic consciousness over time loses the basic elements of its content (the belief in a universal spirituality, in conversion, etc.), but the form of expression of aesthetic value ideas remains almost untouched, it is only slightly modified, and therefore lives for centuries," she explains (Eremina 1978: 27).

Images of domestic animals (ox, cow, horse) are widely presented. The image of a horse has the most semiotic load among them. The horse (an essential attribute of a young man, Cossack, soldier, or brother) is the main means of movement. This image symbolizes the faithful companion, helper, or friend. Buying a horse is directly connected with departure to war: “- Oj, kamu ž ty, ajčeńka, kupliaješ kaničeńka i tak siĺnieńka plačaš? - Dlia ciabie, moj synočku, pajedzieš na vajnočku, na čužuju staronu" (Oh, to whom do you, Dad, buy a horse and are crying for so much? - For you, my son, you will go to war in another land) (Fiadosik 1987: № 54). The horse receives the mandate to report to relatives about the death of a soldier, recruit, Cossack, or a young man at war:

- Oj ty, koń, ty, moj koń, koń, tavaryšak moj, zaniasi,

ty moj koń, ajcu, maciery paklon.

Nie skažy ž ty, moj koń, što ja ŭbity liažu, a skažy ž ty, moj koń, što žanaty chadžu.

Ažanila mianie kulia bystraja, abviančala mianie šablia vojstraja.

(Fiadosik 1987: № 249)

- Oh, you, the horse, you, my horse, the horse, my friend, bring reverence, my horse, to my father and mother.

Do not tell, my horse, that I am lying dead

but tell, my horse, that I got married.

I was married to a fast bullet, I was married to a sharp sword.

The horse (or horses and oxen, horses and cows, which form association complexes) also serves as an indicator of well-being, wealth, and prosperity: "Choć ty sabie znojdzieš z kaniom i z valami, a taki nie znojdzieš z čornymi bryvami..." (Even though you find a girl with a horse and oxen, you will not find a girl with black eyebrows...) (Šyrma 1959: № 20).

The image of the fish symbolizes the girl: "Dziaǔčynačka, maja rybka, nie plač, nie tužysia..." (Girl, my fish, don't cry, don't be offended...) (Fiadosik 2005: № 167). A pair of fishes - the roach and the perch - semantically reflects an ideal relationship between two lovers. Parting with a girl is also as unnatural as the separation of fish with water, or roach and perch.

A significant place in the image system belongs to floral (plant) images. Floral (plant) images are used to indicate gender (birch, willow, viburnum, mountain 
ash, apple, cherry, spruce, pine, rose, etc. symbolize a woman; sycamore, oak, knapweed, wormwood, hops, etc. - a man). In the social lyrics, some traditionally female images (apple, spruce) are used to refer to male characters, due to the specificity of the genre type. Birch, viburnum, willow, rowan, spruce, pine, cherry, sycamore, and oak mark the place where emblematic events happen: a meeting of lovers, loss of virginity, a soldier's death. Female dendrological images - cherry, birch, cranberry, raspberry, apple - represent beauty, attractiveness, and youth. Pairs of trees in songs are examples of the ideal relationship between lovers.

Floral (plant) images are also mediators between our own and the alien world (a potion) and correlate with the lower circle of the universe (grass). Grain crops (rye, wheat, barley, etc.) form association complexes and act as an undivided whole. Viburnum, pine, cherry, and tarragon are in constant communication with the concept of an unhappy fate or obstacle. Growing over trees/bushes / grass represents obstacles, an impossible meeting, or a return to the parental home. The images of the rue, rue-mint, and rue wreath are semantically related to virginity. Coded in the expressions trample rue and feed the horse in the rue are situations connected with the sphere of intimate relations.

In Belarusian folk songs lyrics weather images are widespread. The image of frost semantically reflects obstacles and difficulties: "Oj, za liutymi za marozami Ruta-miata nie ŭschodzić. A za liudskimi nahavorkami Ka mnie mily nie chodzič" (Oh, because of the fierce frost the mint doesn't rise. And because of people's gossip my dear doesn't visit me) (Hilievič 1976: 110). In this case, the lexeme is used with the epithet fierce, which emphasizes an irresistible force. The absence of frost, respectively, indicates a carefree life: “Oj, zieliena, zieliena u luzie trava. Čamu jana zieliena? Marozu niama. Oj, molada, molada u muža žana. Čamu jana molada? Bo dolia ladna" (Oh, green, green grass is on the meadow. Why is it green? There is no frost. Oh, the husband has a young, young wife. Why is she so young? Because her fate is so lucky) (Hilievič 1976: 210).

Opposite to fierce frost as cold, is a white bed that represents home, warmth, and rest. The advent of the frost semantically represents the end of free life, being recruited. Opposite to the dew is the frost. In general, in lyrical songs the lexeme dew occurs precisely in the context associated with walking barefoot. The semantics of bare feet is directly linked to the sphere of intimate relations, and the dew is linked with the male sphere. Valodzina and Vuhlik emphasize that acts of putting on shoes or trampling have a certain erotic function and become metaphors of the act of fertilization (2011: 326).

The image of wind characterizes activity and dynamism, as indicated by the frequent use of the lexeme as the subject of an action. Its semantics has a relationship with a harmful effect or prevention, as indicated by the verbs to 
blow, to break, to twist, to break off, to break up, to lift, etc. The image of wind referred to at the beginning of the song does not portend a happy solution, but rather points to a certain complexity - an unhappy family life, fate; a bastard child; going into the army, service in the army; gossip. This image also semantically reflects a messenger that reports news. In Belarusian folk song lyrics wind acts as a cause of waves that fill the boat with a heroine, which indicates its destructive nature. A husband compared with the wind emphasizes his difficult character. The image of rain is used for a sketch of the overall picture, describing the weather, during which the plot unfolds. A miracle is often described as something that takes place without the participation of nature forces. Another common meteorological image is the fog. This image usually takes a semantically marked position - at the beginning, and indicates the tragic denouement of the plot. The lexeme fog is opposite to the sun - an analogue of the upper circle of the universe. This image is semantically related to obstacles. The image of a cloud typically used at the end of the song, when lovers part, is associated with the divergence of black/dark clouds. A black cloud forms an associative complex with dark/human glory: “- Dziaǔčynańka mila, Čym budzieš ukryvacca Na Ǔkrainie daliokaj? - Ciabie ǔkryje čorna chmara, Mianie ǔkryje ciomna slava Na Ǔkrainie daliokaj" (- Dear girl, what will you be covered with in distant Ukraine? - You will be covered by the black cloud, I will be covered by dark glory in distant Ukraine) (Hilievič 1976: 110).

Gastronomic elements are also associated with the encoding of intimate relationships (to eat fish, to sup on fish). Gastronomic images relate to the motifs of loss of virginity, unhappy fate, verifying the human qualities of the lyrical heroine. The use of magic potion is a transition from the "alien" world to "our" world and vice versa. The associative complex bread - salt symbolizes prosperity.

Numbers also take an important place in the songs. The number three has a sacred characteristic and is used to describe "reality": it refers to the triad of characters, which are realized through the representation of the three-circle universe; highlights the particular character; and indicates time, place, action, the number of objects or phenomena, etc., which are central to the plot. The number three is a significant compositional principle, the essence of which is found in the triple repetition of similar designs. The number two is used for pairing, which is implemented in the images of a pair of lovers, spouses, two brothers, sisters, friends, or young men. The number four is related to the formula three - the fourth, by which the value of completeness is passed. The number seven is related to the performance of certain actions; it means "many" or denotes the border or age of consent. In some contexts, the numbers three and seven act interchangeably. Forty is semantically significant as a time interval, which is given to man for the final transition to the world of people, and corresponds to the concept of "a long time". 


\section{CONCLUSIONS}

The aim of the article was to show the worldview of Belarusian folk song lyrics. In folk songs the world - a specific, limited space which is inhabited by people is formed by heaven and earth. The world is oriented vertically (top - bottom) and horizontally (east - west).

In folk song lyrics the earth is the epitome of femininity (expressions such as earth-mother). The associative complex damp land - yellow sand is semantically related to the grave. The heaven is the "mirror" of the most important, significant events on the ground. In a small group of songs heaven is the place of God's location.

The man with his private destiny has a central place in the worldview of folk song lyrics. In songs the image of a man is determined not only by the presence of body parts, organs, and fluids (head, eyes, lips, face, hair, eyebrows, arms, hands, feet, blood, flesh, bones) but also the soul and mind. Fate "is given" at the moment of birth by the mother/God and it accompanies the lyrical hero throughout life, but it can be changed in the transition to a new stage of life or by personal volition, so the destiny is not absolute. Personal destiny acts as a personalized concept in Belarusian folk song lyrics.

The lower circle of the universe strongly correlates with valley, grave, and grass, and the upper - with mountain, sun, moon, and stars. Mediators between the "alien" and "our" space are a bird and a horse. The image of the garden symbolizes "our" space, whereas Ukraine, Crimea, etc. symbolize the "alien" one. Such images as grove, road, tree, forest, sea, bridge, the river, the Danube, etc. reflect distinct spatial characteristics of the borderland. In the "foreign" territory is grass, a cranberry, a Cossack (deceased), two young men (injured), a Chumak, a soldier, a horse, a grave, death, fog, a wellspring, etc. Images of birds, a cuckoo, a nightingale, two nightingales, a peacock, a lady, a Cossack, daddy, mummy, sister and brother, a flower, berries, cherries (berries), an apple, a pear, a grape, sugar snap peas, sugar gooseberries, flowers, a lily, a blue flower, a one-year flower, pink flowers, a pink flower, a herb, a root, mint, hops, leaves, spring, a bed, a house, etc. are associates with "our" space. At the same time the boundaries between them are moving and depend on the action of binary oppositions.

Images of the same group have their own meaning sphere and perform specific functions. Individual characteristics depend on the species of the genre of Belarusian folk song lyrics. Astronomical images are semantically associated with the sphere of kinship: sun - mother, girl, father, an old man; moon - father, star - daughter, mother, sister. Time is also encoded in astronomical images. Sunset, the appearance of stars in the sky, moonrise and stars indicate the onset of the dark time of the day (evening, night); sunrise indicates the dawn; bright 
sun indicates the daytime or day. Violation of the primordial order indicates the presence of a specific problem, description/decision in which the plot of the song consists. Calendar-chronological images are semantically connected with regulation of work and rest. The appropriate time of the day (day), days of the week (Monday, Tuesday, Wednesday, Thursday, Friday, Saturday), and seasons of the year (spring, summer) are intended for work. Night, Sunday, and winter are intended for rest. Sunday has a special semiotic loading in Belarusian folk song lyrics. Transitional ceremonies (birth, marriage, death, as well as being recruited, meeting with God, an illness) are connected with it. Landscape-topographical images mark "our" territory, a symbolic place, the center, where events significant for a song happened; they act as a boundary locus, and represent the "alien" world. Plant images are used to indicate the sex and age of characters and designate the place where the emblematic event happened. Animalistic images represent sex-age affiliation, the social status of lyrical heroes, and the ideal relationship between two lovers. Images of animals are mediators between "our" and the "alien" space. Somatic elements - head, shoulders, hands, foot, face, hair, tress, lips, eyes, eyebrows, body - represent the man in Belarusian folk song lyrics. Body parts are symbols of certain abstract concepts: head - mind; heart - feelings; face, eyes and eyebrows - beauty, youth, and are the objects of physical pressure. The concept of the body is used to designate a dead/injured man. Meteorological images are semantically related to obstacles and correspond with the motifs of an unhappy fate, being recruited, loss of virginity, or a bastard child. Gastronomic images are indicators of prosperity and used to refer to sexual relations; semantically represent the loss of virginity or unhappy fate; are used in the sense of checking the moral and ethical qualities of women, and indicate the transition from an alien world to our own or vice versa. Numbers are used to indicate the number of characters; to highlight the particular character/object; to indicate time, place, and action or the number of objects, phenomena, etc., which are central to the story. In some contexts, in song lyrics numbers are interchangeable.

\section{ACKNOWLEDGEMENTS}

The article was written as part of a project financed by the Foreign Ministry of Estonia through the Developmental Cooperation Programme (66-2015-A).

\section{NOTES}

1 By Tsivyan's definition (1990: 5), a picture of the world, projected to a specific genre of folklore, is "a shortened and simplified reflection of the entire amount of ideas about the world in this tradition, taken in their systemic and operational aspects". 


\section{REFERENCES}

Baiburin, Al'bert 1993. Ritual v traditsionnoi kul'ture: strukturno-semanticheskii analiz vostochnoslavianskikh obriadov. [The Ritual in the Traditional Culture: Structural and Semantic Analysis of the East Slavic Rites.] St. Petersburg: Nauka.

Baiburin, Al'bert 2005 [1983]. Zhilishche v obriadakh i predstavleniiakh vostochnykh slavian. [Dwelling in the Rites and Beliefs of the Eastern Slavs.] Moscow: Iazyki slavianskoi kul'tury.

Bulgakovskiy, Dmitriy 1890. Pinchuki: Etnograficheskii sbornik. [Pinchuki: Ethnographic Collection.] St. Petersburg: Tipografiia V. Bezobrazova i Komp. Available at http:// www.bookva.org/books/74, last accessed on 26 April 2018.

Citovič, Hienadź 1975. Antalohija bielaruskaj narodnaj piesni. [Anthology of Belarusian Folk Songs.] Minsk: Bielaruś.

Citovič, Hienadź 1959. Piesni bielaruskaha naroda: Vybranaje. [Songs of the Belarusian People: Favorites.] Minsk: n.p.

Čurkin, Míkalay 1949. Bielaruskija narodnyja piesni i tancy: muz.-fal'kl. zb. [Belarusian Folk Songs and Dances: A Musical and Folklore Collection.] Mínsk: Dzyarzh. Vyd-va BSSR. Red. muz. lít.

Czeczot, Jan 1844. Piosnki wieśniacze z nad Niemna i Dźwiny, z dołaczeniem pierwotwornych $w$ mowie stawiano-krewickiéj. [Peasant Songs from the Niemen and Dvina Rivers.] Wilno: Druk. J. Zawadzkiego. Available at http://www.dbc.wroc. $\mathrm{pl} /$ dlibra/doccontent?id=6883, last accessed on 26 April 2018.

Czeczot, Jan 1846. Piosnki wieśniacze z nad Niemna i Dźwiny, niektóre przystowia i idiotyzmy, w mowie stawiano-krewickiej, s postrzeżeniami nad nia uczynionemi. [Peasant Songs from the Niemen and Dvina Rivers.] Wilno: Druk. J. Zawadzkiego. Available at http://www.dbc.wroc.pl/dlibra/doccontent?id=6887, last accessed on 26 April 2018.

Dobrovol'skiy, Vladimir 1903. Smolenskii etnograficheskii sbornik. [Smolensk Ethnographic Collection.] Vol. 4. St. Petersburg: Tip. V.Vasil'yeva.

Duchits, Lyudmila \& Lobač, Uladzimir 2011. Dalina. [Valley.] Mifalohija bielarusaŭ. [Mythology of Belarusians.] Minsk: Belarus, pp. 139-140.

Eremina, Valeria 1978. Poeticheskii stroi russkoi narodnoi liriki. [Poetic Structure of Russian Folk Poetry.] St. Petersburg: Nauka.

Federowski, Michał 1958. Lud biatoruski na Rusi Litewskiej. [The People of Belarus in Rus Lithuania.] Vol. 5: Pieśni. [Songs.] Kraków \& Warszawa: Państw. Wydaw. Nauk.

Federowski, Michał 1960. Lud biatoruski na Rusi Litewskiej. [The People of Belarus in Rus Lithuania.] Vol. 6: Pieśni. [Songs.] Kraków \& Warszawa: Państw. Wydaw. Nauk.

Federowski, Michał 1969. Lud białoruski na Rusi Litewskiej. [The People of Belarus in Rus Lithuania.] Vol. 7: Suplement do t. 5 i 6. [Supplement to Vol. 5 \& Vol. 6.] Kraków \& Warszawa: Państw. Wydaw. Nauk.

Fiadosik, Anatol (ed.) 1978. Piesni pra kachannie. [Love Songs.] Minsk: Navuka i technika.

Fiadosik, Anatol (ed.) 1984. Siamejna-bytavyja piesni. [Family Songs.] Minsk: Navuka i technika.

Fiadosik, Anatol (ed.) 1987. Sacyjaĺna-bytavyja piesni. [Social Songs.] Minsk: Navuka i technika. 
Fiadosik, Anatol (ed.) 2005. Faĺklor u zapisach Jana Čačota i bratoŭ Tyškievičaŭ. [Folklore Written Down by Yan Chechot and the Tyszkiewicz Brothers.] Minsk: Bielaruskaja navuka.

Gil'tebrant, Petr 1866. Sbornik pamiatnikov narodnogo tvorchestva v Severo-Zapadnom krae. [The Collection of Folk Art in the Northwest Territory.] Vil'na: Tipografiia Romma R. M.

Golovacheva, A. V. 1993. Kartina mira i model' mira v pragmatike zagovora. [The Picture and the Model of the World in Pragmatics of Charms.] In: V. Ivanov (ed.) Issledovaniya $v$ oblasti balto-slavyanskoy dukhovnoy kul'tury: Zagovor. [Research in Balto-Slavic Spiritual Culture: Charm.] Moscow: Nauka, pp. 196-211.

Harecki, Maksim \& Jahoraŭ, A. 1928. Narodnyja pieśni z meliodyjami: Zbornik. [Folk Songs with Melodies: Collection.] Minsk: Vyd-va In-tu Bielarus. kuĺtury.

Hilievič, Nil 1968. Naša rodnaja piesnia. [Our Native Song.] Minsk: Nar. asvieta.

Hilievič, Nil 1975. Paetyka bielaruskaj narodnaj liryki: slova i vobraz. Paetyčny sintaksis: Hukapis i ryfma. [Poetics of Belarusian Folk Poetry: Word and Image. The Poetic Syntax: Transcription and Rhyme.] Minsk: Vyš. šk.

Hilievič, Nil (ed.) 1976. Liryčnyja piesni: Bielaruski faĺklor u sučasnyh zapisach. [Lyric Songs.] Minsk: BSU.

Hliebka, Piatro 1975. Pytanni historyi, filalohii, mastactva. [Questions of History, Philology, Art.] Minsk: Navuka i technika.

Hrynblat, Mihail 1967. Sacyjaĺna-bytavaja liryka. [Social Songs.] In: Bielaruskaja narodnaja vusnapaetyčnaja tvorčasć: historyka-tearetyčnae dasliedavanne. [Belarusian Oral Art: Historical and Theoretical Research.] Minsk: Navuka i technika, pp. $167-185$.

Hurski, Anton 2002. Pazaabradavaya paeziya. [Nonceremonial Poetry.] Minsk: Belaruskaja navyka.

Kabašnikaŭ, Kanstancin \& Lis, Arsen \& Fiadosik, Anatol \& Ciščanka, Ivan (eds.) 1985. Bielaruski faĺlor: Chrestamatyja. [Belarusian Folklore: Chrestomathy.] Minsk.

Karskiy, Evfimiy 2007 [1916]. Belorusy: Ocherki slovesnosti belorusskogo plemeni. [Belarusians: Essays on Belarusian Literature.] Vol. 3, B. 1. Minsk: Belorus. Entsikl.

Kolberg, Oskar 1968. Białorus-Polesie. [Belarus-Polesie.] Warszawa: Ludowa Spółdzielnia Wydawnicza.

Kuba, Ludwik 1887. Beloruska pisen. [Belarusian Songs.] Slov. sbornik. [Slavic Collection.] Vol. 4.

Lobač, Uladzimir 2013. Mif. Prastora. Čalaviek: Tradycyjny kuĺturny landšaft bielarusaŭ u siemijatyčnaj pierspiektyvie. [Myth. Space. Man: Belarusians' Traditional Cultural Landscape in a Semiotic Perspective.] Minsk: Tehnalogija.

Mažejka, Zinaida 2008. Piesiennaja Liryka. [Song Lyrics.] In: V. Bialiavina \& M. Pilipienka \& I. Čakvin (eds.) Belarusy. [Belarusians.] Minsk, pp. 119-158.

Nikitina, Serafima 1993. Perspektivy slovaria. [Perspectives of the Dictionary.] In: S. Nikitina. Ustnaya narodnaya kul'tura i yazykovoye soznaniye. [Oral Folk Culture and Language Consciousness.] Available at http://philologos.narod.ru/ nikitina/Part_16.htm, last accessed on 7 May 2018.

Nikitina, Serafima 2006. K probleme sostavleniia slovarei iazyka fol'klora. [On the Problem of Compiling Dictionaries of Folklore Language.] In: A. Kargin (ed.) Pervyi Vserossiiskii kongress fol'kloristov: sbornik dokladov. [First Russian Congress of Folklore: Collection of Papers.] Vol. 2. Moscow: Gos. respublikanskii tsentr russkogo fol'klora, pp. 66-82. 
Radchenko, Zinaida 1881. Sbornik malorusskikh i belorusskikh narodnykh pesen Gomel'skogo uezda, zapisannykh dlia golosa s akkompanementom fortepiano Zinaidoi Radchenko. [The Collection of Ukrainian and Belarusian Folk Songs of the Gomel District Recorded for Voice with Piano Accompaniment by Zinaida Radchenko.] St. Petersburg: V. Bessel' i Ko.

Radchenko, Zinaida 1888. Gomel'skie narodnye pesni (belorusskie i malorusskie). Zapisany v Dyatlovitskoy volosti Gomel'skogo uyezda Mogilevskoy gubernii Zinaidoy Radchenko. [Gomel Folk Songs.] St. Petersburg: Tip. V. Bezobrazova i K. Romanov, Evdokim 1886. Belorusskii sbornik. [Belarusian Collection.] Vol. 1: Guberniia Mogilevskaia, vyp.1/2: Pesni, poslovitsy, zagadki. [Mogilev Gubernia, Issue 1/2: Songs, Proverbs, Riddles.] Kiev: Tip. S. V. Kul'zhenko. Available at http:// avidreaders.ru/book/belorusskiy-sbornik-t-1-guberniya-mogilevskaya1.html, last accessed on 27 April 2018.

Sacharaŭ, Siarhiej 1940. Narodnaja tvorčasć lathaĺskich i ilukstenskich bielarusaŭ. [Folk Art of the Latgale Belarusians.] Rīgā: Latv. Baltkrievu Biedrības Izdevums.

Shein, Pavel 1874. Materialy dlia izucheniia byta i iazyka russkogo naseleniia SeveroZapadnogo kraia. [Materials for the Study of the Life and Language of the Russian Population of the Northwest Territory.] Vol. II. St. Petersburg: Imperatorskaia Akademiia Nauk.

Shein, Pavel 1873. Belorusskie narodnye pesni. [Belarusian Folk Songs.] Zapiski Imperatorskogo russkogo geograficheskogo obshchestva po otdeleniiu etnografii, Vol. 5. [Notes of the Russian Geographic Society.] St. Petersburg: Tipografiia V. N. Maikova.

Šyrma, Ryhor (ed.) 1959. Bielaruskija narodnyja piesni. [Belarusian Folk Songs.] Vol. 1. Minsk: n.p.

Šyrma, Ryhor (ed.) 1960. Bielaruskija narodnyja piesni. [Belarusian Folk Songs.] Vol. 2. Minsk: n.p.

Švied, Ina 2006. Kosmas i čalaviek u dendralahičnym kodzie bielaruskaha faĺkloru. [The Space and Humans in the Dendrology Code of the Belarusian Folklore.] Brest: n.p.

Švied, Ina 2011a. Mifalohija kolieru ŭ bielaruskaj tradycyjnaj duchoŭnaj kultury. [The Mythology of Color in Belarusian Traditional Spiritual Culture.] Brest: n.p.

Švied, Ina 2011b. Zialony. [Green.] Mifalohija bielarusaŭ. [Mythology of the Belarusians.] Minsk: Belarus, pp. 197-198.

Tsivyan, Tatiana 1990. Lingvisticheskie osnovy balkanskoi modeli mira. [Linguistic Bases of the Balkan Model of the World.] Moscow: Nauka. Available at http://inslav.ru/ publication/civyan-tv-lingvisticheskie-osnovy-balkanskoy-modeli-mira-m-1990, last accessed on 27 April 2018.

Tyszkiewicz, Konstanty (ed.) 1871. Wilija i jej brzegi: Pod względem hydrograficznym, historycznym, archeologicznym $i$ etnograficznym. [Vilija and Its Riversides.] Drezno: Drukiem I Nakladem J. I. Kraszewskiego. Available at http://pbc.biaman. pl/dlibra/doccontent?id=1690, last accessed on 27 April 2018.

Valodzina, Tacciana \& Vuhlik, Ihar 2011. Naga. [Leg.] Mifalohija bielarusaŭ. [Mythology of Belarusians.] Minsk: Belarus, p. 301.

Valodzina, Tacciana 2011. Noč. [Night.] Mifalohija bielarusaŭ. [Mythology of the Belarusians.] Minsk: Belarus, p. 330.

Varfalamiejeva, Tamara (ed.) 2001-2013. Tradycyjnaja mastackaja kultura bielarusaŭ: $U 6 t$. [The Traditional Artistic Culture of the Belarusian People.] Minsk: Belarusian Science. 


\title{
THE PLEIADES IN THE BELARUSIAN TRADITION: FOLKLORE TEXTS AND LINGUISTIC AREAL STUDIES
}

\author{
Tsimafei Avilin \\ Center for Belarusian Culture, Language and Literature Research \\ National Academy of Sciences, Belarus \\ e-mail:tsimafei@gmail.com
}

\begin{abstract}
This paper presents an analysis of Belarusian names for the Pleiades and their distribution in the territory of Belarus. Based on areal and ethnolinguistic studies, the author proposes the division of astronyms with the volos, vis, and stažar bases into two separate groups. Such an approach helps to understand parallels in astronyms of different groups and to provide another way of reconstructing the Old Slavonic astronym vtasiežjetišči.
\end{abstract}

Keywords: areal studies in linguistics, astronyms, Belarusian folk constellation names, constellations, folk names of constellations, Pleiades, Slavic languages, star folklore

This work focuses on Belarusian folk records about the Pleiades and the linguistic aspect of areal distribution of names for the Pleiades. As will be shown later, methodological approaches inherent in some studies relating to the treatment of linguistic sources sometimes lead to erroneous interpretations.

As a rule, Belarusian sources as well as the folklore and ethnographic texts of the nineteenth and twentieth centuries indicate the presence of $6,7,10$, or 12 (LABNG) stars in this stellar cluster. But it is the number seven (Blr. sem) that was the basis of some folk names for the Pleiades and the Great Bear constellation: Siamiźviozdačka (Kaśpiarovič 1927: 305), Siamiaryčki, Siemizviezdzica (LABNG).

Another motivational component for naming this star cluster was its visible features: the stars in the sky seem to be piled in a heap, placed close to each other in a small area of the sky. Folk descriptions present the stars as if they are in "a heap" (Blr. u kučcy, in Blr. dialects also hurbačka, kupka (ibid.), hromadka (PA), "a heap of stars" (Blr. kučka zorak) (Fig. 1). 


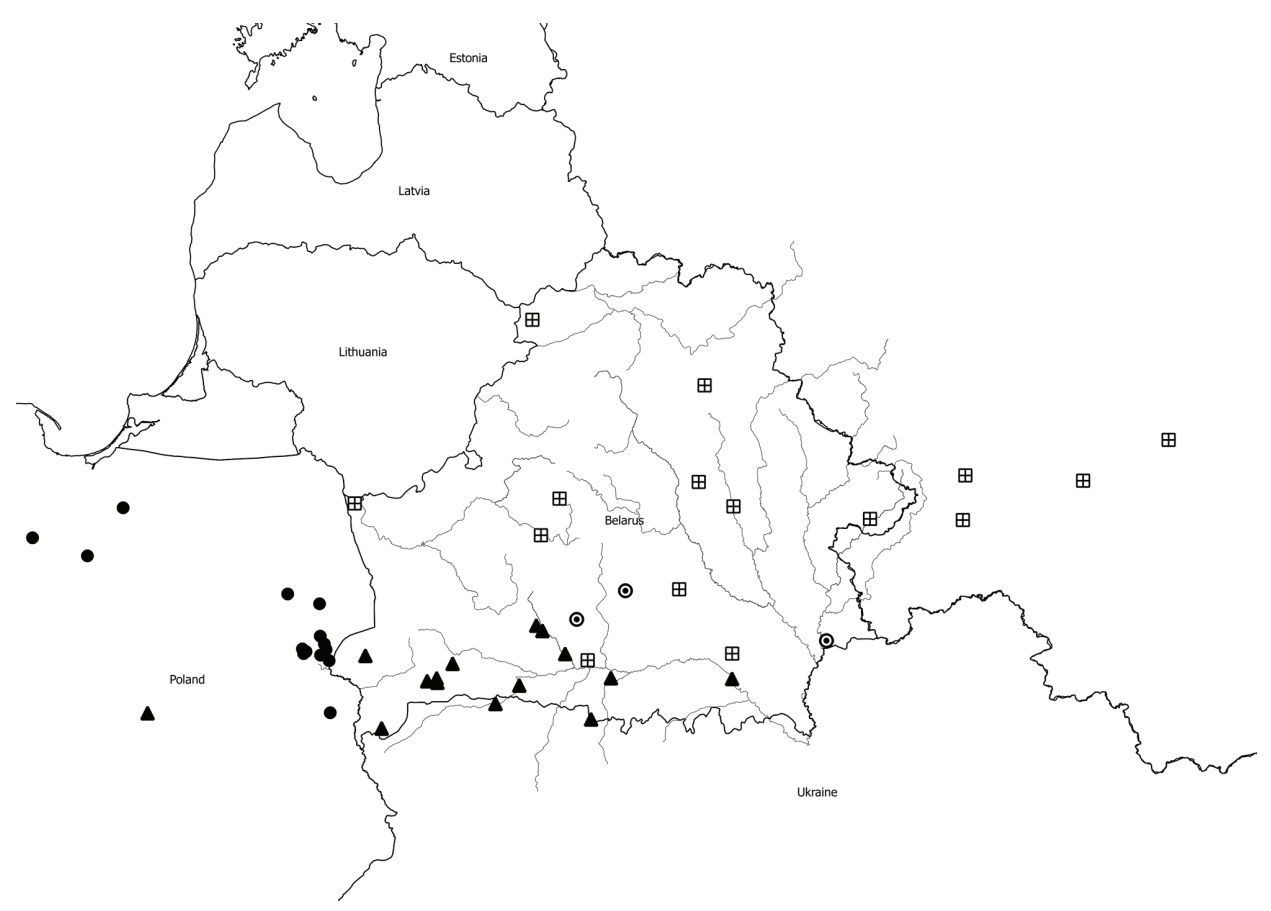

Figure 1. Different models of nominating the Pleiades.
- 'kupka model
( - 'kučki' model
- 'hromadka' model
田 - 'stažary' model

Thus in the general sense, the internal form of an astronym can be represented as a complex of similar objects. These objects are implemented in anthropomorphic, zoomorphic or objective codes, for example, the Sieve (Blr. Sita 'a complex of holes'), the Hens (Blr. Kurački 'a complex of hens or hen with chickens'), Valoski (the root valos means 'the hairs', 'a complex of hairs'), etc.

The following models for names for the Pleiades are implemented in Belarusian tradition. 


\section{THE SIEVE MODEL}

Two main dialectological forms can be found - Sita (Sitačko, Sitca, Sicca, etc.) and, considerably rarer, Rešata (Rašotka, Rešatni, etc.). In the first place this cluster appears in the memory of informants in the context of determining time: "The Sieve rose higher, it's midnight, the cocks will crow" (Cychun 1993: 128); "A heap of stars to determine the time"; "The Sieve is the seven stars which rise in the east in the great night when the sky is clear, and when they set then the day is coming" (LABNG).

There is no textual variety in the main corpus of the field and archival records or such descriptions in the ethnographic sources. But definitely some exceptions exist - they are a kind of "Folk Bible" recollections. The same can be found in other European folk texts.

While describing this star cluster, sources often draw an obvious parallel between the holes in a sieve and the stars: "Sitečko. So, it looks like sifted flour. The same in the sky: many stars in a heap" (Avilin 2015); "there are also [the Little Sieve, Blr. Maloe Sita] holes, small stars" (ibid.); “The Sieve (Blr. Sita) of stars ... the stars [in the Sieve] as the holes, there are many of them" (ibid.); "Siciečka (a little Sieve) - many, many stars as intertwined" (ibid.); "[Why was it called the Sieve?] So, I don't know, maybe because it begins to sow corn from the autumn for the winter. Close to autumn, after the Sieve has risen, it began to sow corn" (ibid.). Also notice a quite popular Belarusian riddle: "How many stars in the sky, so many holes in the ground" (key - a stubble (the lower part of the grass stem after harvesting).

In the Słuck and Homiel regions some beliefs indicate this sieve is a place where souls are being sifted: "The Sieve is fiery candles in the sky in the place where righteous souls get together. Angels sift here the righteous souls from the wicked" (Sieržputoŭski 1930: 7); "The souls are sifted - the wicked to hell, and the righteous to paradise" (Avilin 2015). Meteors were interpreted in a similar way: if a star falls, it indicates that the human soul flies from Purgatory. The famous Polish-Belarusian writer Mickievič described this heavenly sieve as a reminder about the first creations of God: "To the north shines the circle of the starry Sieve, through which God, as they say, gifted grains of corn, when he cast them down from heaven for Adam our father, who had been banished for his sins from paradise" (Mickiewicz 1834: 136-137).

Some traditions close to the Belarusian one, like those from Poland and Lithuania, also represent etiological legends about the Pleiades in a "Folk Bible" context. For example, a known Polish belief tells where the view of this sieve appears in terms of the most prominent Christian story, the Nativity: “...three 
kings left a sieve, which was used to sift oats for their horses, together with gifts for Jesus... This sieve was used by the mother of Jesus, Mary, and after her assumption she hung the sieve between the stars in the sky" (ESBM 2005: 278). A similar story was found in the Lithuanian Mariampol region:

Mary had a sieve to sift flour, but one day the sieve disappeared. She found out that a devil had stolen the sieve and she sent Saint Mark to return the sieve. The devil didn't want to give the sieve back and Saint Mark had to fight with him. While struggling, they bent the sieve and Mary couldn't use it anymore. Therefore, she hung it in the sky, where we can see it now and call it the Sieve. (Balys 1951: 17)

Considering typical artificial mythologization of many folklore characters by romantic researchers in the nineteenth century, certain doubts appear regarding texts written by Ludwik Adam Jucewicz. In his work of 1846, the author mentions that Mejlus, the son of the goddess Lauma, was thrown into the sky and placed among the Pleiades stars (Jucewicz 1846: 19-20).

Etimology of one Prussian astronym of the sixteenth century, paycoran = paytoran seems to be disputable. On the one hand, Mažiulis reconstructed it as *saitāran (Lithuanian. sietýnas, Latvian. siêtiņš) (Pleiades) (Mažiulis 2007: 62), on the other, in the teamwork Indogermanische Forschungen the following interpretation is proposed: "paycoran 'Hyaden': lit. paikas oras", i.e., associated with the notion "rainy" (Brugmann \& Streitberg \& Leskien 1900).

Generally, the astronyms of this group are known in the Finno-Ugric and Baltic regions: in Lithuanian, Setas (a sieve), dangaus setas (a heavenly sieve); in Estonian "an old sieve" (Prüller 1966: 166). They are also found in the Caucasian territory (Khalidova \& Iusupova 1988: 34).

\section{THE HENS MODEL}

In the territory of Belarus, in the Western Polesia region (Fig. 2), the popular Western European astronym of the hens model can be found. Among Belarusian variations of this astronym the following can be pointed out: Kuročka (LABNG; PA), Kurki (Moszyński 1928: 156), Kury (Avilin 2015), Kurica (PA), etc. Though in Western European texts the view of the Pleiades is represented as a hen with chickens, Belarusian sources do not show such etiologies: "Kuročka - a group of stars, a little collection, there are about 10 stars in one heap - the one is big and around it - small stars... Kuročka has risen" (Avilin 2015); "One star is called Kuročka" (PA). Moreover, in the Belarusian dialects of Western Polesia the name of a hen which leads chicks is basically presented by the following 


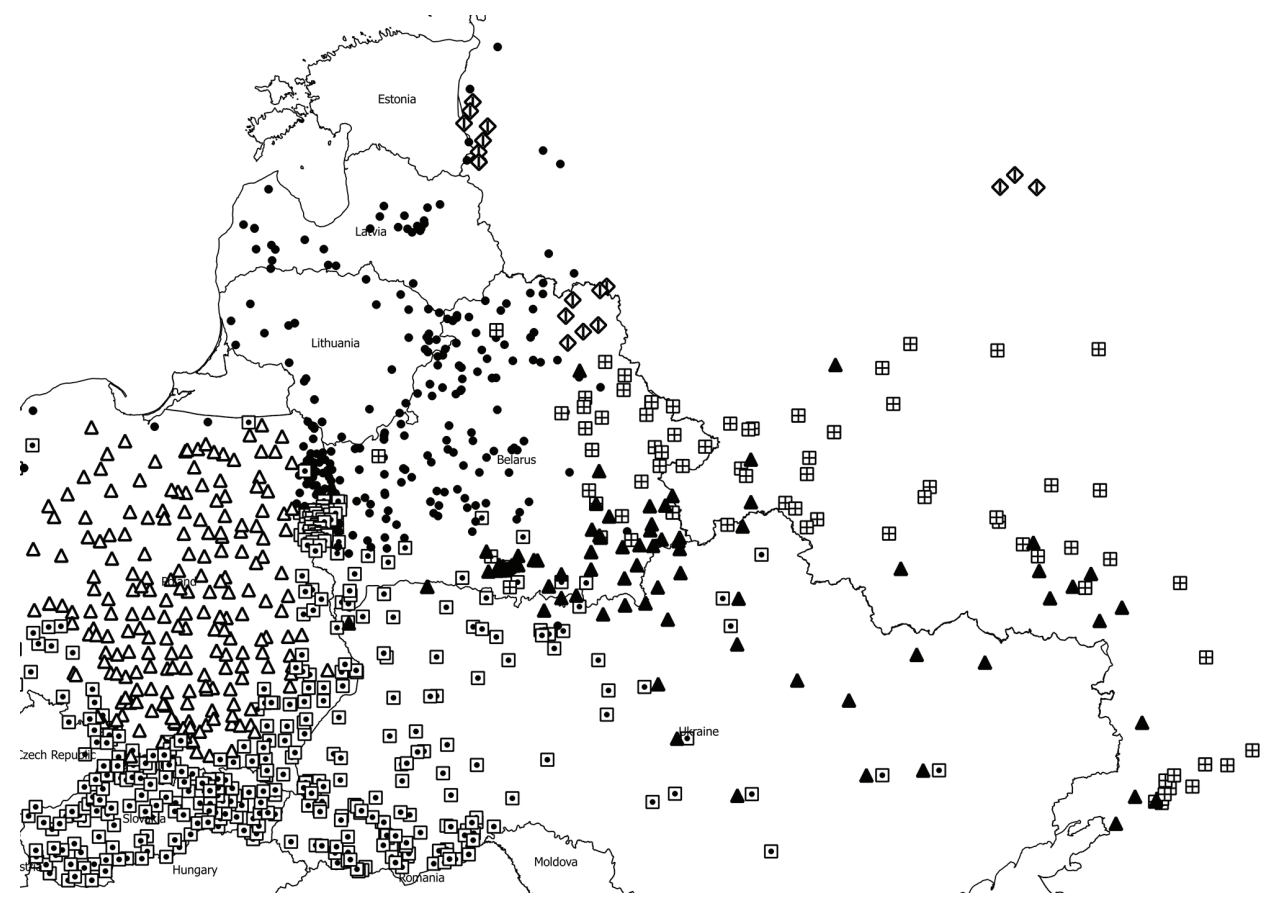

Figure 2. Different popular models of nominating the Pleiades.

$$
\begin{aligned}
& \boldsymbol{0} \text { - 'sieve' model } \\
& \boldsymbol{\square} \text { - 'hens' model } \\
& \Delta \text { - 'baby' model } \\
& \boxplus \text { - 'visožary' model } \\
& \Delta \text { - 'volosožary' model } \\
& \boldsymbol{D} \text { - 'valosyni' model }
\end{aligned}
$$

lexemes: kvokša, kvočka, kvaktucha, kvakucha - none of these matches the Belarusian astronym of the hens model.

Incidentally, an interesting Croatian legend is relevant: "The hen which saved a church" (Pleiades; kvočka 'a hen'). There was a church that enemies wanted to destroy. In front of the church Kvočka was sitting on a tree. They came at night and cut down the tree. Kvočka fell down and began to fly and scream so loudly that people woke up and saved the church. The criminals fled and they could not be caught. At that time, the people heard a shout - they went on shouting for Kvočka until they reached the place where the criminals were hiding and Kvočka's scream subsided. While arresting the criminals, someone 
looked at the sky, where there was a bunch of stars similar to the hen, which was named Kvočka (Valjavec 1867: 221). In the Vladimir region it is not recommended to put the hen on the eggs until the Pleiades are visible in the sky:

It's bad to put a hen on the eggs when the Siemik is in the sky. Nothing good will come of it. A hen is put on the eggs when there is no Siemik in the sky. From Yuri's day of spring to Theodore Stratelates day there is no Siemik - let the hen sit. Otherwise even if it sat then disease would choke the chickens. (Dobrovol'skaia 2011: 23)

Siemik is derived from the Russian siem 'seven', in accordance with the number of stars in the Pleiades.

Of particular interest is the areal distribution of this astronym in Belarus Western Polesia and beyond it - the southeast of Poland and west of Ukraine. This astronym is also found in Western Europe and the Balkans.

\section{THE SEVEN PERSONS MODEL: 'WOMEN', 'SEVEN MEN'}

Widely distributed in Poland is the astronym Baby (Bel., Pol., Rus. baby 'women'), which can be found in Belarus only in border regions (Braslawszczyzna 2010: 453). At the beginning of the nineteenth century, Dalenha-Chadakoŭski indicated that this astronym was known around Minsk and the whole of Belarus (Spravochnyj 1849: 8), though the map of the areal distribution of the Pleiades (Fig. 2) does not confirm his statements. In Łastoŭski's vocabulary this astronym Baby (Łastoŭski 1924: 476) could be included due to a desire of the author to expand the kryŭski lexicon as much as possible.

Nevertheless, in cultural terms, this astronym was very important because it had been used for several centuries in works written in Polish by scientists and writers from the Commonwealth of Poland. It was also important in religious and spiritual books like different translations of the Bible, such as the Radzivil Bible and the Niasviž Bible. In Polish literature, the astronym baby appears in 1466 at least (Słownik 1991: 312).

Folk etiology of this astronym is based on the concepts of mutual mapping between the celestial and earthly worlds - celestial bodies are anthropomorphized and "socialized" as people: "Babki (Pleiades) Kosiarom (Bel. Kosar - 'a mower'; Orion) carry something to eat" (Gładyszowa 1960: 36). Close parallels can be found in the Grimm legend about an evil baker and his wife and six daughters (Grimm 1854: 691-692), and a Prussian legend about a tyrannical husband who turns into a cuckoo and his wife and six daughters turn into the Pleiades (Frischbier 1882: 439-440). 
Siem Malciev (seven men) is another astronym of this model, which can be found in the autobiographical work of the Belarusian writer Janka Sipakoŭ (1936-2011): "There is the Pleiades, or in Zubrevičy village it is called Siem Malcov. Or it is also called Sito (a sieve)" (Avilin 2015), and this is a unique fixation at this time. However, the southern Slavs even give names to these seven starry brothers (the Pleiades or Ursa Major): (in Serbia) there are seven stars in Vlašiči: "Mika and Mioka, Raka and Raoka, Orisav and Borisav and the seventh one is Milisav" or "Vole and Voleta, Rale and Raleta, Mile and Mileta and the smallest one is Pržožak" (Rovinskiy 1901: 442). Refering to other sources, Jankovič points to more variations: "Vao and Vaska, Mio and Mioka, Skarabojo and Borisav and the smallest one is Biliurak"; "Mile and Mileta, Rade and Radeta, Bore and Boreta and the smallest one is Prigimaz"; and "Ale and Aleta, Šurko and Burko and the smallest one is Mišurko" (Janković 1951: 139).

\section{OTHER NAMES FOR THE PLEIADES}

Among individual and rare astronyms is Hniazdo (a nest) (Avilin 2015); "A heap of stars is a Bouquet of Flowers" (a source said that she came up with this name herself) (ibid.); Gromadki (Gładyszowa 1960: 185) seems not to be a name for the cluster but a description of it: "Gromadka of small stars - Kuročka" (where gromadka could be a synonym for a heap, a group) (PA), although such astronym is recorded in the Simbirsk, Vyatka, and Ural dialects (Azim-Zade 1980: 98). It is interesting that the Korona (a crown) astronym - "Korona. Koronka - stars in a heap" (PA) is also found in the Ukrainian part of Polesia in the form of Venočok (a little wreath) (ibid.), Koruna (a crown) (ibid.), and also as a description of the Sieve - "Sitco ascends by the morning, it looks like a wreath or a sieve" (Avilin 2015). Compare also with a Belarusian one - "A crown is made with twelve stars and put on Jesus's head. It can usually be seen in winter" (Corona Borealis?) (ibid.).

\section{ASTRONYMS OF THE VAEASAŽAR, VISAŽAR, VAEOSKI, VAEASYNI, AND STAŽARJE TYPES}

Researchers and informants associate typical astronyms of this group with different objects in the sky: the Pleiades, Ursa Major and Ursa Minor, sometimes Orion, Cassiopeia or another constellation which was a folk invention. A particular Ukrainian name for the Milky Way is also known: “This is a bird's 
way; the birds fly in vyrej (a mythical place in Slavic mythology); this way is called volosožery" (PA).

In Belarus all of the above types of astronyms can be found; moreover, they form their areals, which have a continuation/beginning in the neighboring countries.

For example, the following names of Ursa Major are known: Stožar (PA) (variants: Stažary, Stažarje), Sažór - "Sažor is far, it's not a time to get up" (ibid.); the Pleiades - Stažáry (ibid.), Stažerka (Kaśpiarovič 1927: 291) - "Look at Stažerku, is it time to thresh?"; Stažarja (Dobrovol'skij 1894: 348), from stažarje - "scaffolding under the haystack". Similar Estonian names are also known for the Corona Borealis (Prüller 1966) and the Russian Sažáry (Avilin 2015).

Among astronym variations of the volosožar type, the following (often associated with the Pleiades) are also found: Vołosozár (ibid.) - "Vołosozar rises close to autumn, there are many stars in one place - the day becomes shorter and the night becomes longer"; Vałasazar (PA), Vałasažár - "Vałasažar has risen very high - it will be 12 o'clock soon" (LABNG); Vałasažary (PA), Vałasažaryk (Avilin 2015), Cary-votosozary - "The six stars in the same place are called votosozary, cary-vołosozary" (ibid.), etc. Vielisazar is known as a unique name: "Vielisazar is in the south, so it's time to thresh" (Kaśpiarovič 1927: 56).

Another group is composed of astronyms of the visažar model (often the Pleiades, rarely Ursa Major): Visyžár - "Get up to thresh, soon the day will come: visyžar has already risen in the sky" (Bialkievič 1970: 110); Visažár - "Going to thresh depends on Visažár, if it's in the south, it's time to go" (LABNG); Visažór (ibid.), Wosożary - "Kosory i wosożary, gdy ukazują się na niebie - to zbliża się jesień" (Kosory and Wosożary - when they appear in the sky, then the autumn is coming) (Gładyszowa 1960: 187), and the variations Vysažar, Vesežar, and Vysožar.

For the last, a small group of astronyms is characterized by the presence of the volos part and lack of such formants like (žlz)ar: Vatósynia, Vałosy, Vatosøny (LABNG), Vałoski, and Vatosny - "Vatoski in the dawn - a horse in a plow" (Kaśpiarovič 1927: 52). This type is mostly known in Russian in the Pskovsk region: Rus. Vołosynia (Slovar' 1970: 63), Vołosýnje (Ursa Minor, the Pleiades), Vołosýnia (Ursa Major, the Pleiades), Votosnica (Slovar' 1979: 123, 125). Moreover, this type of astronym occurs in a diary of the merchant Nikitin from the fifteenth century, who was from Tver (votosyny) and in a vocabulary written by Tonis Fenne at the beginning of the seventeenth century in Pskov (Votosyni).

In its rather poor textual diversity, the fixed astronyms in the context of linguageographical analysis provide interesting results not previously discussed 
by scholars. The areal distributions can create new findings on the etymology of these groups of astronyms and possible cross-ethnic contact.

We presume that it is methodologically improper to consider all four variants of astronyms to be derived from a common name. As can be seen in Figure 2 , astronyms of the types like votosyni, visožary, and votosožary form separate areals, and astronyms of the stažary type seem to occur sporadically (at least for the territory of Belarus). In addition, while analyzing these names, many researches directly appeal to Church Slavonic astronyms, especially to vtasiežjetišči form, without considering its other variations which can be found in different texts. But the linguistic mapping, together with the involvement of folklore and ethnolinguistic materials, shows that it makes sense to allocate two separate subgroups, at least for the East Slavic area: 1) astronyms of the stažary and visažary type, and 2) astronyms of the votosožary and vołosyni type.

Similar generalizations of individual fixations of folk motifs or lexical units are discussed in many papers. In some cases, the existence of lexical units or folk motifs is generalized to entire regions, which of course appears doubtful and can lead to far-fetched interpretations. The reason is obvious: the researcher does not always have the opportunity to gather all the available material and see its local areal distribution. This is the case with fundamental papers and catalogs such as the Dictionary of Russian folk dialects (Slovar russkih narodnyh govorov-SRNG) or Thematic classification and distribution of folklore and mythological motifs on habitats: An analytical directory, prepared by Y. E. Berezkin. Regarding the latter, some Belarusian folk motifs are extrapolated to the whole territory of Belarus, although their detailed review may indicate the presence of isodoxa (a line dividing the elements of spiritual culture) (such as in the case of the "moon carrier" motif) or the apparent crossborder invasion of neighboring ethnic groups (the case of "the moon spots" or the Twardowski motif).

A detailed linguistic analysis of all forms and contexts in which there are astronyms of these groups is beyond the scope of this paper. Nevertheless, I believe it is important to point out some key points that, in my opinion, have been overlooked in studies by other authors, including some incorrect statements found in reputable papers.

Let us start with the popular astronym vtasiežjetišči, which is found in Church Slavonic sources and often used in research papers. In most cases, a number of authors use the form vłasiežjetišči while ignoring other variations, for example, vłasožjelišti, vłasožjelca, vtasožjelci, vłasožjelcz, vtasožlć, vtasožilešč, vtasožilišči or vtasiežjelišči (Slovar' 1899: 70). As correctly noted by Fomina, similar names are composite: vtasie and žjetišče (for the vtasiežjetišči form) (Fomina 1995: 274), 
where vtasie is the shape of the original Slavic name for the constellation, and žjełišče is "a place of mourning"; moreover, the vtasie astronym can be found in Vladislavov sbornik in 1465 (Khristova-Shomova 2007: 119-130). In my opinion, the second formant was interpreted incorrectly: instead of "a place" (a place of mourning, the graves, etc.) (RES 2012), it should be interpreted as žita (a sinew). Compare with Church Slavonic-žiła (a sinew), žity rečnyje (river streams), žity hoviažyje / vołovyja (ropes or whips made of bullock sinews), and the known Old Church Slavonic names of the Pleiades - vlasoželbci, vlaso(-žilišti / -želišti) (Skok 1971: 609). Sometimes it means foal (D’iachenko1900: 185), žitavz (sinewy), žitica (vein) (Slovar' 1899: 219-220). In the Lexicon of 1627 by Berynda: žiliščnyj - žiłovatyj (sinewy), mocnyj (strong), tuhij (tight), žilicie (a small sinew). Also in Macedonian: žilišta - "a place to live", but this word also means "sinew", and a rich set of forms in Bulgarian are derived from the semantic foundation žiła: žilest, žilici, žitka, žiłaviec, etc. A similar interpretation is valid in logical and semantic terms - in Job 38:31 we can find: "Can you bind the chains of the Pleiades? Can you loosen Orion's belt?" That is, vtasie žjetiščnyj can be interpreted as "tight hair: a 'knot of tight hair' or 'tight knot of hair". However, it is possible that the translators themselves might have mistakenly understood žjeliščje as "a place". The proposed hypothesis can easly interpret the considered astronym, but there are still many open questions in the field of its phonetic transformations.

Khristova-Shomova attempted to reconstruct this composite astronym as a 'hairy turtle' which looks very fantastic (Khristova-Shomova 2007: 125), and resembles the pagan Slavic god Volos - it is difficult to imagine that a Christian scribe "popularized" the pagan god. She referred to a fundamental work Issledovaniya $v$ oblasti slavyanskih drevnostey (Research on Slavic Antiquities) written by Ivanov and Toporov, which actually has some inaccuracies that occur in the context of the analysis of the names of constellations and related texts on pages 49-50; for example, the statement “...staroe nazvanie Plejad... soedinjaetsja s arhaicheskim naimenovaniem Poljarnoj zvezdy Los', otrazhennym $\mathrm{v}$ arhangel'skih govorah" (the old name of the Pleiades ... is connected to the archaic name of the North Star as 'Moose', which is reflected in the dialects of Arkhangelsk) (Ivanov \& Toporov 1974: 49-50). At the same time, in accordance with Nikitin, it can be seen that this is a separate constellation or a star and in no way connected to the North Star (ibid.): “...a los' golovoju stoit na vostok" (... and the moose's head is to the east). The North Star cannot point to the east because humans attributed this star with the following functionality: 1) the star always stays in the same place; 2) it points to the north. Moreover, a unique lexical item in the Arkhangelsk dialects can be defined as Ursa Major, and not the North Star. Furthermore, there are indications about 
the-ynja suffix, but in Nikitin's text, according to the dictionary by Sreznevskij, the volosyny (Sreznevskij 2003: 1256) form can be found, but the stress position is unknown.

In addition, the author indicates that votosožary originates from the Pskov region, but in the SRNG dictionary to which the authors refer, votosožary is recorded with a question mark and is an explanation for the Votosýnia astronym. This situation often occurs in mini-dictionaries and folklore-ethnographic works from the nineteenth to twentieth centuries, when instead of a Greek analogue it is known to the compiler of the dictionary by the local astronym (in this case the Pleiades). Most likely, this record might have been collected or interpreted by a native from Ukraine or southeastern Russia. Secondly, as seen in Figure 2, the Votosožary astronym areal does not extend so far to the north.

On page 50, in a section about the Eastern Slavic Volos again, in my opinion, these authors mistakenly added visožary to a common group that will be shown below. Some criticisms are voiced by Strakhov about the wiredrawn "Peryn" as the name of the goddess (Strakhov 2003: 154-155).

As concerns the Mordovian Vele (the Pleiades, a swarm, a village), such a name is typologically consistent with the known Eastern and Western Slavonic astronyms that mean a "bunch" or "pile", for example, Bel. Kučki, Kupki, Hramadka, Kupa, and Pol. Gromadka or Kupa. These are not connected with the mythological view and are the simplest and probably most archaic forms of the description of the Pleiades, which have nothing in common with theistic reconstructions.

Thus, it becomes clear that in the section devoted to Votosyni, many things have not been explained, and obviously erroneous references have been included. Additionally, in this part of the paper various professional researchers and amateurs of "Slavic antiquities" are actively referenced.

Let us consider the etymology of the visožary astronym, which in many studies is supposed to be a transformed form of votosožary, votostožary, vołosožary, etc., and sometimes, again, it is associated with the god Volos.

As can be seen in Figure 3, the astronym with the explicit prevalent form visožary is popular in the Bryansk and Orel regions. In Belarus, most likely, this astronym has lost its original meaning, which has led to a large number of variants pointed out above. Nonetheless, the following meanings of visožary exist in the Bryansk and Orel regions: visožár - "a tall man", "a high tree", "the name of a bird", and as a synonym for visljáj - "a tall man with non-noble figure" (Slovar' 1989: 51-52). According to the ESBM, visožary is possibly a contaminated lexeme from vysokij (high) and podžarnyj (slabsided) (ESBM 1978: $91,160)$. 


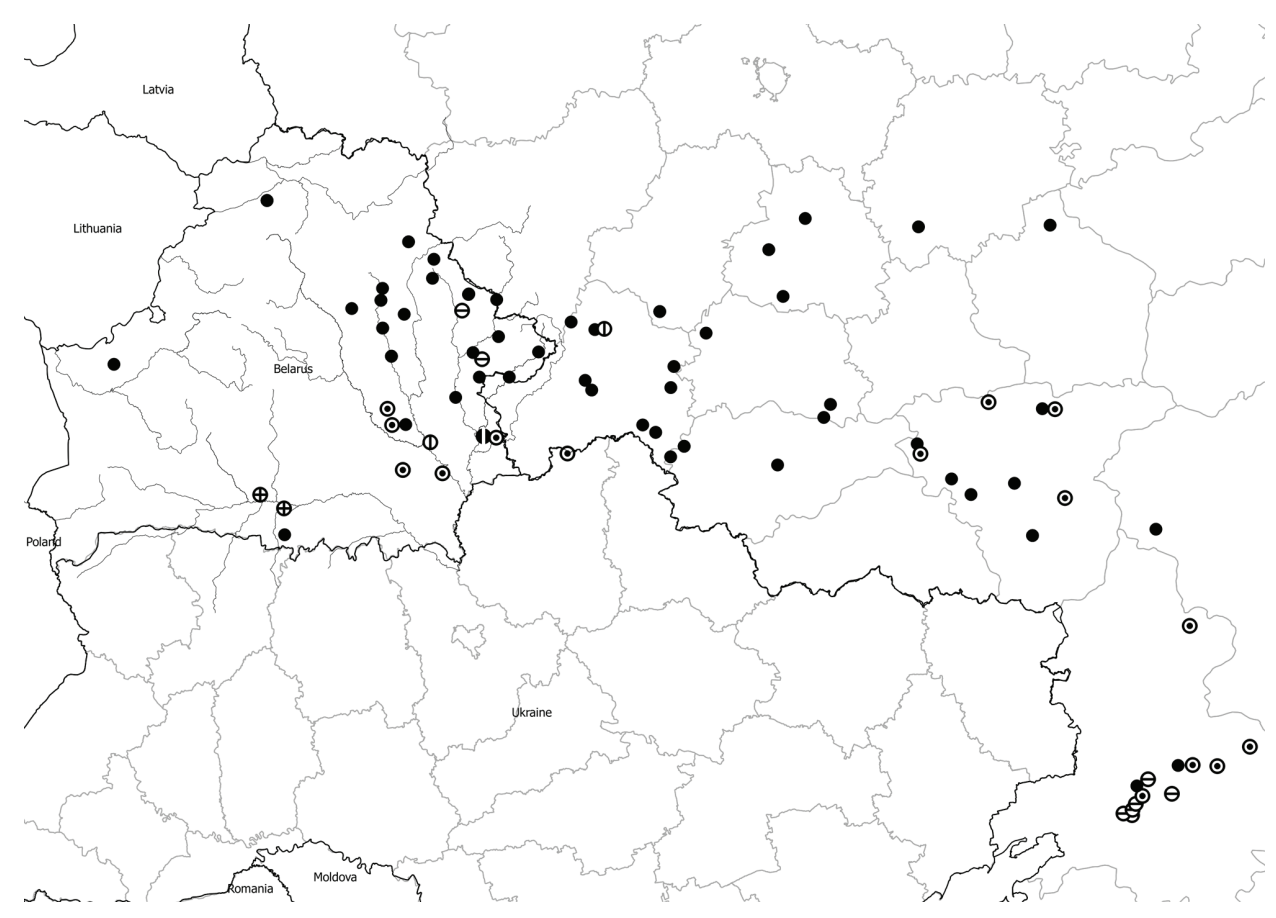

Figure 3. Different vowels in the root of visožary.
vis-
( vas-
$\ominus$ vjes-
(1) ves-
$\bigoplus$ vos-
(1) vys-

Let us look at some examples that may indicate the historical and semantic parallel between stažary and visožary.

According to archeological data, it is known that the Yukhnovsk archaeological culture, which is believed to have been influenced by Scythian culture, has been extended to the territories of Chernigov, Bryansk, Orel, and Kursk. Some traces of the Scythian language can be found in the Bulgarian and Ossetian languages. Therefore, we try to consider some examples of these two seemingly distant languages. The Bulgarian vis may mean 'the top of a mountain', 'the top of a tree', and could be connected with the Indo-European *(v)-upsis, wherefrom, according to the compilers of the dictionary, Bulgarian visok and viš are also 
derived (Balgarski 1971: 152-153). The Bryansk visožary - 'tall person' and the Orel visožary - 'high tree' fall into the 'something or someone tall or high' semantic field, which is close to the 'top of something' semantic field.

Now let us consider the example from Ossetian. According to Abaev, the Ossetian wis / wes (rod, long switch) goes back to vaiša and corresponds to the Slavic věcha, or 'pole', meaning a stick in the ground to indicate the path, and the Latin virga (from *vis-ga) (rod, twig) (Abaev 1965: 314). On the other hand, according to Max Vasmer, who has examined visožary and vesožary as a part of stožár vocabulary article, the following forms are known in different Slavonic languages: the Russian stožár (a fence around the haystacks) and the Old Russian stožáro (a pole stuck in the ground to strengthen the stack), stožárbnz (tax on the stack); the Bulgarian stóžar, stóžer (piles hammered in the barnyard); the Serbo-Croatian stožer (piles hammered in the barnyard); the Slovenian stožér (pole in a haystack); the Czech stožár (mast); the Slovak stožiar (mast). Further etymology is associated with stežer (a rick, a stack) (Vasmer 1987: 764). Compare with the Lithuanian stãgaras (long dry stalk of a plant), the Latvian stagars (the same, with an alternating vowel), and Lithuanian stegerys (a dry stem, a dry footstalk). Additionally, in the Belarusian and Ukranian languages a comet is sometimes called vieha.

Thus, when considering the far etymologies, we find a convergence between stožar and visožar, and it becomes clear where the meaning 'a tall man' comes from - this is a comparison with a tall pole in the center of a stack of hay. This result could also correspond to the onomasiological model specified by Mladenova for the majority of the names of the constellations as 'signs' (Mladenova 2004: 48-54). However, in this case, we get closer in semantic convergence too. Apparently, Vołosožar, the astronym which is typical of eastern Ukraine and southwest Russia, was originally a descriptive adjective like visožary, or podžaryj (slabsided). On the other hand, the formant-žary could occur due to the influence of the areal of visožary with which they border. A separate issue requiring resolution is the cause of the separation of areals with the foundation volos (Vołosyni, Vołosožar) by the visožar areal. We note an interesting observation: in the Old Bulgarian language, according to Cejtlin, nouns with the suffix $-y n i$ were formed from "a basis of qualitative adjectives. Almost all of them have abstract meanings, and they usually express different moral and ethical concepts" (Cejtlin 1986: 198-199).

At the end of the paper, I would like to reveal some etiological legends about visožary. From the former Tula province: Visožary appeared in the sky because forty brothers were tortured for their Christian faith (Avilin 2015). Forty brothers are the Forty Martyrs of Sebaste who did not bring sacrifice to the pagan gods and were tortured for it. In memory of these martyrs a holiday called 
Soroki (Rus. sorok - 'forty') was established, which also symbolizes the beginning of spring. This time falls on the day of the heliacal rising of the Pleiades in the astronomical context.

In the Kursk region, another variant reads as follows:

At first God created all the stars as dense and rife as Visažary and a view of the stars was amazing. But one night some people went along the road and they started talking among themselves, saying: 'so this Visažary we planted with Grandfather' and then during the conversation they fell into a deep ravine and were maimed, and the Lord began to beat them with a whip from the sky saying: 'Do not look at the sky and see the wheels.' Since then cripples and stars have become rare, only Visažary the Lord stayed dense and rife. (Sviatskij 1913: 146-147)

As in the story about the forty martyrs, here the motif of mangling is present; the observation that earlier all constellations looked like Visažary is also interesting. Compare with a prohibition to look at Orion or Kostylik (a spike-nail): "Must not, must not show Kostylik to kids until they begin to run, because it says - the baby may become lame" (Dobrovol'skaia 2011: 23).

\section{ACKNOWLEDGEMENTS}

The article was written as part of a project financed by the Foreign Ministry of Estonia through the Developmental Cooperation Programme (66-2015-A).

\section{REFERENCES}

Abaev, Vasilij 1965. Skifo-evropeiskie izoglossy: Na styke Vostoka i Zapada. [ScythianEuropean Isoglosses at the Junction of the East and West.] Moscow: Nauka.

Avilin, Tsimafei 2015. Pamiž niebam i ziamloj: Etnaastranomija. [Between Heaven and Earth: Ethnoastronomy.] Minsk: Technałohija.

Azim-Zade, Jel'han Gejdar Ogly 1980. K sopostavitel'nomu analizu slavianskikh i tiurkskikh nazvanii sozvezdii. [To the Comparative Analysis of the Slavic and Turkic Names of the Constellations.] Sovetskoe slavianovedenie, Vol. 1, pp. 96-103. Available at http://inslav.ru/sites/default/files/sovslav-1980-1.pdf, last accessed on 3 May 2018.

Balgarski 1971 = Bălgarski etimologičen rečnik. [Bulgarian Etymological Dictionary.] Comp. by V. Georgiev \& I. Galabov \& I. Duridanov \& J. Zaimov \& S. Ilchev. Vol. 1. A-Z. Sofia: Izdatelstvo na Balgarskata akademija na naukite.

Balys, Jonas 1951. Tautosaka apie dangu. [Folklore of the Sky.] Sodus, Mich.: J.J. Bachunas. 
Bialkievič, Ivan 1970. Krajovy stoŭnik Uschodniaj Mahiloŭščyny. [Regional Dictionary of Eastern Mogilev Area.] Minsk: Navuka i technika.

Braslawszczyzna 2010 = Brastawszczyzna: Pamięć $i$ wspótczesność. Tom II: Stownictwo dwujęzycznych mieszkańców rejonu (Stownik brasławski). [Braslaw Region: Memory and Present. Vol. II: Dictionary of Bilingual Residents of the Region (Dictionary of the Braslaw Region).] Edited by Elzbieta Smulkowa. Warszawa: Wydawnictwa Uniwersytetu Warszawskiego.

Brugmann, Karl \& Streitberg, Wilhelm August \& Leskien, August 1900. Indogermanische Forschungen: Zeitschrift für indogermanische Sprach- und Altertumskunde, Elfter band. Strassburg: K.J. Trübner. Available at https://archive.org/ details/indogermanische11unkngoog, last accessed on 3 May 2018.

Cejtlin, Ralia 1986. Leksika drevnebolgarskih rukopisej X-XI vv. [Lexis of Ancient Bulgarian Manuscripts of the 10th-11th Centuries.] Sofia: Izdatel'stvo Bolgarskoj akademii nauk.

Cychun, Apanas 1993. Skarby narodnaj movy. [Treasures of the National Language.] Grodno: Yanka Kupala State University of Grodno.

D’iachenko, Grigorij 1900. Polnyi tserkovnoslavianskii slovar'. [Complete Church Slavic Dictionary.] Moscow: n.p. Available at https://azbyka.ru/otechnik/ Grigorij_Djachenko/polnyj-tserkovnoslavjanskij-slovar.html, last accessed on 3 May 2018.

Dobrovol'skaia, Varvara 2011. Zaprety i predpisaniia, sviazannye s narodnoi astronomiei v traditsionnoi kul'ture tsentral'noi Rossii. [Forbiddances and Regulations Related to Folk Astronomy in the Traditional Culture of Central Russia.] In: I. S. Rouda (ed.) Fal'klor i suchasnaja kul'tura: Matjeryjaly III Mizhnar. navuk.-prakt. kanf., 21-22kras. 2011 g., Minsk. In 2 vols. Vol. 1. Minsk: Vyd. tsentr BDU, pp. 22-25.

Dobrovol'skij, Vladimir 1894. Smolenskii etnograficheskii sbornik. Chast' II. Zapiski Imperatorskogo Russkogo Geograficheskogo Obshchestva po otdeleniiu etnografii. [Smolensk Ethnographic Collection. Part 2. Proceedings of the Imperial Russian Geographical Society of the Department of Ethnography.] Vol. 23, Part I. St. Petersburg: Tipografiia S. N. Khudekova.

ESBM 1978 = Etymałahičny stoŭnik bietaruskaj movy. [Etymological Dictionary of the Belarusian Language.] Vol. 2. Minsk: Bieł. navuka.

ESBM 2005 = Etymatahičny stoŭnik bietaruskaj movy. [Etymological Dictionary of the Belarusian Language.] Vol. 10. Minsk: Bieł. navuka.

Fomina, Liudmila 1995. Rol' Ioanna Ekzarkha Bolgarskogo v razvitii vostochnoslavianskoi astronomii. [The Role of John the Exarch of Bulgaria in the Development of East Slavonic Astronomy.] In: M. Tikhova \& P. Dimitrov (comps.) Preslavska knizhovna shkola: Izsledovaniia i materialy. Vol. 1. Sofia: Universitetsko izd-vo Sv. Kliment Okhridski, pp. 269-276. Available at https://drive. google.com/file/d/1q4IrAyhC5Cgxntw7Vp_KhjJvawSVIRc9/view, last accessed on 3 May 2018.

Frischbier, Hermann 1882. Preussisches Wörterbuch: Ost- und westpreussische Provinzialismen in alphabetischer Folge. Erster Band. Berlin: Verlag von Th. Chr. Fr. Enslin. Available athttps://archive.org/stream/preussischeswrt03frisgoog\#page/ n5/mode/2up, last accessed on 3 May 2018. 
Gładyszowa, Maria 1960. Wiedza ludowa o gwiazdach. [Folk Knowledge about the Stars.] Wroclaw: Zakład Narodowy imienia Ossolinskich.

Grimm, Jacob 1854. Deutsche Mythologie. Dritte ausgabe. Göttingen: Dietrichsche Buchhandlung.

Ivanov, Vyacheslav \& Toporov, Vladimir 1974. Issledovaniya v oblasti slavyanskih drevnostey. [Research on Slavic Antiquities.] Moscow: Nauka.

Janković, Nenad 1951. Astronomija u predarima, obichajima i umotvorinama Srba. [Astronomy in the Traditions, Customs and Folk Literature of the Serbs.] Srpski etnografski zbornik, Vol. 63, Zhivot i obichaji narodni, Vol. 28. Beograd: Srpska Akademija Nauka.

Jucewicz, Ludwik Adam 1846. Litwa pod względem starożytnych zabytków, obyczajów i zwyczajów, skreślona przez Ludwika z Pokiewia. [Lithuania under the View of Ancient Relics, Beliefs and Faiths Written by Ludwik from Pokiewia.] Wilno: Nakl. Rubena Rafalowicza. Available at https://archive.org/details/ litwapodwzgldem00jucegoog, last accessed on 3 May 2018.

Kaśpiarovič, Mikalaj 1927. Viciebski krajovy słoŭnik. [Dictionary of the Vitebsk Region.] Viciebsk: Instytut Belaruskaj Kultury.

Khalidova, Misai \& Iusupova, Chakar 1988. Problemy mifologii i verovanii narodov Dagestana: sbornik statei. [Problems of Mythology and Beliefs of the Peoples of Dagestan: Collection of Articles.] Makhachkala: Dagestanskii filial AN SSSR, In-t istorii, iazyka i lit-ry im. G. Tsadasy.

Khristova-Shomova, Iskra 2007. Nazvanijata na sozvezdieto Plejadi v starite slavjanski prevodi na kniga Jov. [The Names of the Pleiades Constellation in the Old Slavonic Translation of the Book of Job.] Balgarska rech, Vol. 13, No. 2, pp. 119-130.

LABNG = Leksičny attas bietaruskich narodnych havorak. Handwritten files of the Lexical Atlas of the Belarusian folk dialects.

Łastoŭski, Vacłaŭ 1924. Padručny rasijska-kryŭski (biełaruski) słoŭnik. [RussianKryuski (Belarusian) Dictionary.] Koŭna: Druk. A. Baka.

Mažiulis, Vytautas 2007. Iš Baltų etimologijos. [From Baltic Etymology.] BALTISTICA, Vol. 42, No. 1, pp. 61-68. DOI: 10.15388/baltistica.42.1.943.

Mickiewicz, Adam 1834. Pan Tadeusz. Księga òsma. Zajazd. [Pan Tadeusz. Book 8. Road House.] In: A. Mickiewicz \& J. Kallenbach (eds.) Pisma Adama Mickiewicza: wydał objaśnit $i$ wstepami poprzedzit Josef Kallenbach, Vol. 4. Warszawa \& Krakow \& Lwów \& Poznan: Wyd. dzieł wyborowych Marjan Haskler, pp. 69-112.

Mladenova, Darina 2004. Balkanskii tip astronomicheskoi sistemy. [The Balkan Type of Astronymic Systems.] Voprosy onomastiki, Vol. 1, pp. 48-54. Available at http://www.ruslang.ru/doc/onomastica/onomastica1text.pdf, last accessed on 3 May 2018.

Moszyński, Kazimierz 1928. Polesie Wschodnie: Materjały etnograficzne z wschodniej części b. powiatu mozyrskiego oraz z powiatu rzeczyckiego. [Eastern Polesia: Ethnographic Materials from the Eastern Part of the Former Mozyr Region and from the Rechytsa Region.] Warszawa: Wydawn. Kasy im. Mianowskiego. 
PA = Polesskij Arhiv. Digital version of the Polesia archive of the Department of Ethnoliguistics and Folklore of the Institute of Slavic Studies of the Russian Academy of Sciences.

Prüller 1966 = Priuller, Paul Egon. Estonskaia narodnaia astronomiia. [Estonian Folk Astronomy.] Istoriko-astronomicheskie issledovaniia, Vol. 9, pp. 145-170.

RES 2012 = Russkii etimologicheskii slovar'. [Russian Etymological Dictionary.] Edited by A. E. Anikin. Vol. 6 (val-vavershok). Moscow: Rossiiskaia akademiia nauk.

Rovinskiy, Pavel 1901. Chernogorija v eja proshlom i nastojashhem. [Chernogoria in the Past and Present.] Sbornik Otdeleniia russkogo iazyka $i$ slovesnosti Imperatorskoi Akademii nauk, Vol. 69, pp. 1-646. St. Petersburg: Tipografiia Imperatorskoi Akademii nauk. Available at https://www.prlib.ru/item/363817, last accessed on 3 May 2018.

Sieržputoŭski, Aleksandr 1930. Prymchi i zababony bietarusaŭ-palešukoŭ. [Prejudices and Superstitions of Belarusians-paleshukou.] Minsk.

Skok, Petar 1971. Etimologijski rječnik hrvatskoga ili srpskoga jezika. [Etymological Dictionary of the Serbian and Croatian Languages.] Vol. 1. Zagreb: Jugoslavenska Akademija Znanosti i Umjetnosti.

Slovar' 1899 = Slovar' drevnego slavianskogo iazyka, sostavlennyi po Ostromirovu evangeliiu. [Dictionary of the Old Slavic Language, Compiled According to the Ostromir Gospels.] St. Petersburg: Izd. A.S. Suvorina. Available at https:// www.prlib.ru/item/678518, last accessed on 3 May 2018.

Slovar' $1970=$ Slovar' russkih narodny hovorov . [Dictionary of Russian Folk Dialects.] Vol. 5 (voenstvo-vyrostkovyi). Leningrad: Nauka. Available at http://iling.spb. ru/vocabula/srng/srng_05.pdf, last accessed on 3 May 2018.

Slovar' 1979 = Pskovskii oblastnoi slovar's istoricheskimi dannymi. [Dictionary of the Pskov Region with Historical Data.] Vol. 4 (vi-votachka). Leningrad: Izdatel'stvo Leningradskogo universiteta.

Slovar' 1989 = Slovar' orlovskih govorov: Uchebnoe posobie. [Dictionary of Orel Dialects: A Textbook on Russian Dialectology.] Vol. 2. Yaroslavl: Iaroslavskii gosudarstvennyi pedagogicheskii institut imeni K. D. Ushinskogo.

Słownik 1991 = Stownik staropolski. [Dictionary of Old Polish Language.] Vol. 10, No. 4 (64) (wjechać-wronię). Warszawa: Zakład Narodowy im. Ossolińskich; Kraków: Wydawnictwo polskiej Akademii Nauk. Warszawa.

Spravochnyj 1849 = Spravochnyi entsiklopedicheskii slovar'. [Referential Encyclopedic Dictionary.] Vol. 2. St. Petersburg: Izdanie K. Kraiia. Available at https://www. prlib.ru/item/451318, last accessed on 4 May 2018.

Sreznevskij, Izmail 2003. Materialy dlja slovarja drevnerusskogo jazyka. [Materials for an Old Russian Dictionary.] Vol. 1 (A-K). Moscow: Znak.

Strakhov, Alexander 2003. O kollektsii pistsovykh zapisei M. G. Gal'chenko (posleslovie redaktora). [About the Collection of Scribal Records Collected by M. G. Galchenko (Editor's Afterword).] Palaeoslavica, Vol. 11, pp. 145-146.

Sviatskij, Daniil 1913. Pod svodom khrustal'nogo neba: Ocherki po astral'noi mifologii $v$ oblasti religioznogo i narodnogo mirovozzreniia. [Under the Roof of the Crystal Sky: Essays on Astral Mythology in the Field of Religious and Folk Worldview.] St. Petersburg: Tipografiia M. M. Stasiulevicha. 
Tsimafei Avilin

Valjavec, Matija 1867. Narodne priče, navade, stare vere. [Folk Stories, Traditions, Old Faith.] Slovenski glasnik, Vol. 13, pp. 62-63.

Vasmer, Max 1987. Etimologicheskii slovar russkogo iazyka. [Etymological Dictionary of the Russian Language.] Vol. 3. Moscow: Progress. 


\title{
THE PROBLEMS ASSOCIATED WITH STUDYING FOLK VERSE
}

\author{
Jury Paciupa \\ Center for Belarusian Culture, Language and Literature Research \\ National Academy of Sciences, Belarus \\ e-mail:paciupa@gmail.com
}

\begin{abstract}
The article studies the problem of internal mechanisms of folk verse. An approach that is based on the universals of rhythm, where a verse is described with due account for levels (syllable, syntagma and phrase), is offered. As the basic element of the verse, colons, the invariant structure of which is determined by the law of regressive accentual dissimilation, is considered. A set of stanzas of folk verse seems to be a combination of invariants: archritmemas and their modifications, the prototypes of which can be observed in interjections and echoism. Prose-centeredness (prose is normal, while verse is an anomaly) is criticized. The author suggests a system of coding for invariants of folk verse and illustrates it with a number of examples. In the conclusion, the issue of reconstruction of the ancient state of the verse is touched upon, with due consideration of the universals of rhythm, and the problem of areal description for the forms of folk verse.
\end{abstract}

Keywords: accentual, anapaest, archritmema, caesura, clausula, colon, a constant, dactyl, iamb, ictus, measure, rhythm, ritmema, strophe, syllabic, trochee, a universal, verse

\section{INTRODUCTION}

We still do not know anything about how folk verse functions: how it emerges, develops, or what it is based on. The same thing could be said about a literary poem, but there is no recognition of the fact that literary poems have not been studied. Vice versa, there is a feeling of exhaustiveness of the rules of versification, and the science of versification on the whole. In one of his last works, Gasparov claimed quite seriously: "The four fields - metrics, the rhythm system, rhyme, and strophe - have been developed so well that no revolutions are expected there in the near future" (Gasparov \& Skulacheva 2004: 11). Why can these words not also refer to the popular verse? Not only because it has not been described in a sufficiently extensive way. There is no theory of popular verse, even for a first approximation, which would be satisfactory for everyone 
to the extent which is observed in literature. The difference can be explained in a very easy way: The theory for literary verse consists in the rules of versemaking, orthometrics, while popular verse exists without any rules one way or the other, which desires an explanation.

In recent years, from the moment of the first experience of dealing with popular verse (Paciupa 2014), I have developed a theory of the verse in bare outlines, which continues my own previous research (Paciupa 2004) and synthesizes the conclusions made by verse researchers belonging to very different schools, which sometimes contradict each other, above all Potebnya (1884), Kvyatkovskiy (1966, 2008), and Taranovskiy $(2000,2010)$, and in certain aspects I rely on individual ideas and discoveries made by Chudovskiy $(1915,1917)$, Tomashevskiy (1959), Chukovskiy (2001 [1928]), Yanakiev (1960), Timofeyeva (1958, 1987), and Beyli (2001). For a review of my findings, I refer you to my publications (Paciupa 2014, 2014-2016, 2016). In this article, I summarize and uncover the experience of studying popular versification through a number of examples. The understanding of the verse is based on the universals of rhythm and seems to be relevant, at least, for any language that has an expiratory accent.

The purpose of the article is to reveal rhythmical universals of popular verse and create a system of coding for its invariants, which would allow poetic texts to be compared and described in the aerial and time perspective. The following issues should be addressed while pursuing the main goal: 1) brief theoretical basis of the principles of popular verse; 2) analysis of linguistic phenomena, in which rhythmical universals are observed; 3) a description of the system for coding invariants and illustrating it with examples from Belarusian folk poetry; 4) considering the perspectives of using the suggested system. In this article, the invariant-genetic approach to the verse phenomena was used, conclusions were made on the basis of observations over linguistic facts and the phenomena of popular verse, and for a more fundamental understanding of rhythmical processes, comparisons with well-known phenomena in other national traditions were made, both close and distant ones. As an introduction, let us recall a number of critical judgements which were exercised by renowned linguists, but were never taken seriously.

If the statement that "the accuracy of classification determines the accuracy of further studies" is true (Propp 2001: 7), the opposite is also true. In 1923, Yakobson wrote:

The current division of verses into accentual, syllabic, and metrical is inefficient and inaccurate. The unity of the signs of division is not observed. While the accentual principle means a certain way of exercising a strong beat, 'syllabism' only means the measure of the length of a poem or a rhythmical segment; a syllabic verse can be both metrical (Vedic) or 
accentual at the same time, and such syllabic-accentual verse can also have syllabic segments (Russ. <кuü> verse, 19th cent.) or do without them. (Yakobson 1923: 46)

Neither of the "systems" holds up against criticism from the inside either. For example, a "syllabic" verse, unlike some subtypes of "accentual" verse, really exists. It is the oldest type of verse which lies at the origins of not every, but definitely of an overwhelming majority of national traditions. But it is provided with a completely mythical interpretation, in accordance with the name, except for the accentual aspect. Meanwhile, it was Polivanov who wrote the following:

A pure incident of syllabic versification, i.e., the type of versification that is based exclusively on the aspect of the number of syllables in the corresponding parts of speech (verses), free from the accentual aspect, can be found in just a few languages. (Polivanov 1963: 106)

As for "accentual" verse, the term itself is accurate but has no sense - within the scope of the effect of expiratory accent, all verses are accentual one way or another. This being said, some accentual verses in truth turn out to be pentons ("dolnik") (Paciupa 2014-2016, № 11: 23), while the measure of other "accentual verses" is irrational (Shtokmar 1952b).

As the experience of describing verse in very different languages, especially in languages that have recently acquired national attributes (which do not have standardized rules) and even more so, popular verse, has confirmed, reducing it to an unambiguous definition, a well-known "system of versification" is fraught with difficulty. As it has been rightfully pointed out by Tudenov:

In almost all studies of folklore versification or the poetry of a transition period, an obtrusive tendency for looking for one or another common means for rhythm-making is observed, which aims at fitting all of the multiform rhythmical verse-making processes into Procrustean bed, i.e. the frameworks of the existing systems. ... In our opinion, the rhythm of folk verse is set not by a single metrical tool, but by the whole set of metrical means that are used in different national traditions. (Tudenov 1958: 84-85)

\section{LEVELS OF SPEECH AND MECHANICS OF VERSE}

Before addressing the facts, the following aspects should be taken into consideration. Firstly, there are two principles of organization of verse, syllabic and accentual, which are correlated differently in different languages, but neither of them should be completely ignored. Secondly, different levels 
should be distinguished in any poetic text: syllabic, syntagmic, and phrasal, which are correlated with the categories of poetics: syllable, colon, and period. In folk verse, speech and poetic segmentation match almost completely because of the lack of such a phenomenon as enjambment. The element of the most basic verse unit is a colon. Colons have internal structure that is measured by feet, and are united into a system - a period and a strophe (Fig. 1). A foot is an integrant, but not an element of a verse: if we compare colons with elementary particles, feet can be compared with quarks that are impossible to be isolated as individual units. The structural standing point of a colon is a constant, i.e., a final stressed syllable that corresponds to the syntagmatic stress (Fig. 2). Strong stances in the colon are distributed from the constant to the beginning of the verse, in conformity with the law of regressive accentual dissimilation (RAD) (Taranovskiy 2000: 274-282), which determines the invariant of a colon - a ritmema (see the paradigm of ritmems in Fig. 3).

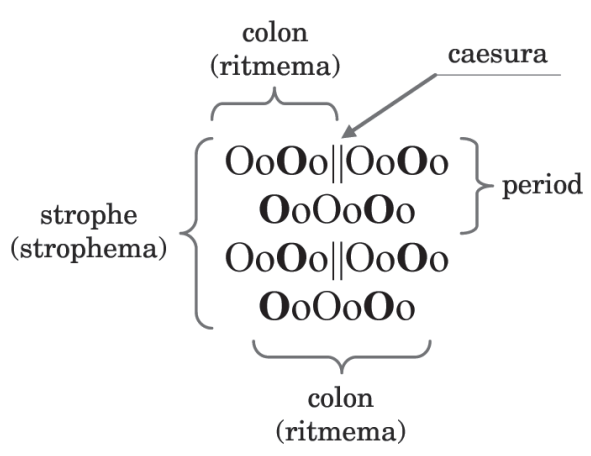

Figure 1. Structure of the strophema $[2(\boldsymbol{a}+\boldsymbol{a}+\boldsymbol{\beta})]$.

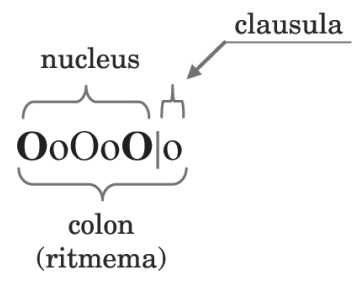

Figure 2. Structure of a colon (archeritmema $\boldsymbol{\beta}$ ). 


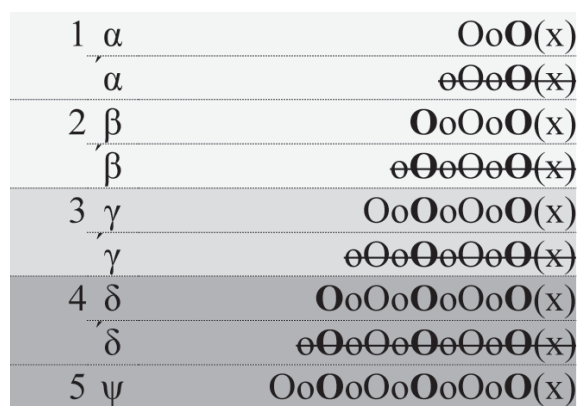

Figure 3. Paradigm of ritmemas (archeritmemas and hyperritmemas).

RAD is a resultant of more basic laws: the law of the final localization of the constant (LC) and the law of the distancing of accents (DA), which was well known to Vostokov and Samsonov (Vostokov 1817: 21-22; Samsonov 1817: 226). In accordance with the latter law, two ictuses cannot stand next to each other, which means that there is no such foot as a "spondee". However, if two accents turn out to be next to each other, one of them is deaccentuated and is no longer an ictus (óó), or there is a caesura (ó||ó) or leymah (ó/\ó) between ictuses. As Taranovskiy wrote later: "A dynamic accent should have two 'inclines' (i.e., a certain number of unstressed syllables before and after it) in order to be more pronounced" (Taranovskiy 2010: 540). Therefore, RAD is a consequence of an expiratory (dynamic) accent, and it manifests itself locally even in trisyllabic meters, for example, in anacrusis anapaest (Paciupa 2004: 308-309). Let us describe how, as a result of interaction between the LC and the DA, the RAD emerges, and then demonstrate this process directly on language facts and indirectly in folklore poetics.

From the DA, it follows that a constant does not tolerate any kind of stress right next to it, and if the stress does appear, it is deaccentuated. And now let us imagine this in motion: taking the constant as a baseline, we move from the end of the colon to the beginning of it. The third syllable allows stress, but a much weaker one. In texts, we most often observe the absence of stress here, or the "abandoned" stress, as Chudovskiy (1917: 63) calls it. Then an unstressed syllable follows, and on the fifth syllable a stress appears, which is more pronounced than on the third one, but is weaker than on the first syllable (i.e., weaker than the constant). This motion never stops until it reaches the beginning of the colon. The sequence of alternations may be different only if two (trisyllabic meters) or four unstressed syllables (pentons) will in some way consistently be forced between stressed syllables. However, trisyllabic meters and pentons are not generated on their own, and if they are, only under specific conditions and within specific limits, which will be discussed below. 
Thus the RAD phenomenon, discovered by Taranovskiy (2000: 275), anticipated by Chudovskiy (1917: 60-63), and to some extent even earlier than that by Kulakovskiy (1890: 2), is not limited to a certain historical period. The "frame" rhythm that does not go along with the RAD has always been an abnormality and never - even in the eighteenth century, when it was mostly used in literary iambic verses - predominated. In folklore, "paeons" were most often detected (Samsonov 1817: 251; Dubenskiy 1828: 55-88) - this is how the RAD was described in terms of metrics. What also matters here is that both the syllabic and the accentual framings form a single whole, where the leading part belongs to the syllabism: the actual number of syllables in the colon, counting from the constant, determines the potential structure - the ritmema.

The ritmema, no matter how we see it - as an effect of the RAD, according to Taranosvkiy, or as an alternating rhythm, according to Tomashevskiy (1959: 41-56), or by means of "check rows" suggested by Kvyatkovskiy (2008: 545-547), or, eventually, as an ancient dipody or as a paeon, observed by Samsonov and Dubenskiy - in any case, it is trimetric, not dimetric. The ritmema contains an alternation of alternations: firstly, ictuses and unstressed syllables alternate, and, secondly, strong (mandatory) and weak (nonmandatory) ictuses alternate too. This surge of alternations, or "a more complex metric unit" (Alandskiy 1875: 81), if you wish, can be called an actual foot, while the feet that are usually used, such as iambic, trochaic, and paeonic feet, always simplify the rhythmic space. They are like the Cartesian coordinate system, like a scale system, external to the object. This is why it is strongly recommended to use both the iambic-trochaic and the paeonic scales in parallel. It is paradoxical, but it has turned out to be equally useful to reject a foot in literature (Chudovskiy 1915: 60), i.e., where it has been expected, and to implement it in folklore (Beyli 2001: 27-78, 386-398), where it has seemed inconceivable. Every single theory has its due time.

The absolutization of one of the principles of the organization of a verse led to the emergence of a number of competing theories of folk verse in the nineteenth century: foot, accentual, syntactic, and musical theories (see Shtokmar 1952a: 17-135), which, as had been pointed out by Taranovskiy, were not antagonistic, but complementary (Taranovskiy 2010: 520-522). The basic element of a verse - the colon - was referred to as a "prosodic period" by Vostokov (1817) and as a "syntactic foot" by Potebnya (1884), which led not only to a confusion of notions, but also to the elimination of the perception of the hierarchical organization of versified speech as it is. Perhaps it was only the musical theory (the most erroneous, by the way) that was not at fault in this case and divided the levels of verse structure. But the tendency for planar perception of a verse, which does not take into consideration either the hierarchical structure of 
a verse text or the trimetric development of the rhythm, is still alive, and it has even been flourishing. This reductive trend is alive in the interval theory of the accentual verse ("dolnik", "taktovik", "purely accentual”), which is the continuation of the school metrics and goes back, perhaps, to Trediakovskiy, who pronounced a verdict on the colon: “сии члены не стихи” (these members of a sentence are not a verse) (Trediakovskiy 2002: 110).

\section{INTERJECTIONS AND RHYTHM UNIVERSALS}

However, in the nineteenth and twentieth centuries, through joint efforts of folklorists, poetry researchers, and linguists, massive factual material was collected. And if we disengage ourselves from individual theoretical discrepancies, it can be said that we are dealing with a quite full perception of the structure and the main forms of the Slavic folk verse, which enables us to reconstruct its development against the background of the development of the Indo-European and panhuman verse. The basic forms of the Belarusian and, more widely, the Slavic folk verse are $8+8,6+6,5+5,8+6$, etc. The combinations of five and six syllables are not divided into smaller elements, while the combinations of eight syllables are divided into $4+4$ or $5+3$. However, the links between these smaller colons are stronger than between large ones, while, on the opposite, the caesuras between them are less clear. These combinations give rise to such phenomena as 8 -syllabic ( $4+4$ and 5+3), 10-syllabic (5+5 and 3+6), 12-syllabic $(6+6$ and 4+4+4), 14-syllabic (8+6), which are known as "syllabic verse", either folk or literary. They constitute the main stock of the proto-Slavic verse (Ivanov \& Toporov 1963). However, such forms occur in Turkic, Mongolian, Finno-Ugric, Caucasian, and other languages, not to mention Indo-European ones. Why do such combinations predominate, and what do they have in common?

If we have a close look not only at the number of syllables in the colon, but also at the localization of the constant, we will notice a consistent pattern: in the colons with the even numbers of syllables, the constant is usually on a next-to-last syllable, while in the colons with the odd number - on the last syllable, which is why the nucleus (i.e., all syllables in the colon or its lines, except for the clausula (Fig. 2)), is initially of two types only - 3-syllabic and 5-syllabic ( $\mathrm{OoO}$ or $\mathbf{O o O o O})$. The 7-syllabic nucleus of an 8-syllabic verse also genetically comes down to these structures. However, most often, 8-syllabic verses are divided into colons in synchrony too: $4+4$ or $5+3$. If the nucleus is 3 or 5 syllables long, and the RAD law applies invariably, there can be no other rhythm except for trochaic. But as soon as the length of the nucleus changes, the trochee disappears (the last example in the article represents a modified 
ritmema of this kind). In order to assure ourselves of the assumptions that have been made and see the interrelation between the length of the nucleus and the structure of the ritmema, perfect conditions are required, under which every single syllable could have a potential of being an ictus, because it stands in the strong position - under the stress. Fortunately, such conditions exist virtually in all world languages, namely in exclamations and onomatopoeias, which will serve us as a "perfect" model for observation.

Let us reproduce a knock at the door: tuk-tuk, the clock ticking: cik-tak; a cuckoo calling: $k u-k u$; and some other similar sounds: buĺ-bul, kap-kap, haŭhaŭ, miaŭ-miaŭ, roch-roch, oj-oj, lia-lia, tak-siak. In every single case of a twopart, complete or incomplete, reduplication of 1-syllable words a stronger stress falls on the last syllable: tuk-túk. This peculiarity is also observed in such words as ki-hi, ku-ha, ču-fy, kuldyk, baŭbyć, šturchiel, čyryk, šarach. The position of stress is not dependent on the nature of vowel sounds or their setting. Of course, you can say it the other way round: túk-tuk, but you will have to make conscious effort to do that. One way or another, the stress in the preposition will always sound less natural. We can say: with formal equality of stressed syllables, a stronger stress falls upon the last syllable. The obtained result verifies a common law: in a neutral style, syntagmatic and phrasal stresses are at the end (Kodzasov \& Krivnova 2001: 386; Bondarko \& Verbitskaia \& Gordina 1991: 116-117). Verse obeys the same LC law. We can abstract our minds from what the onomatopoeia will be - a syntagma (tuk-tuk), a word ( $k u l d y k)$ or a "word-phrase". However, if we change experimental conditions and emphasize both components to a considerable degree: túk - túk; káp - káp, we will observe something like a pause between the two words, which means that the DA law comes into play here. However, it is still too early to make any kind of conclusions on the basis of what we have just seen.

Let us have a look at similar three-syllable combinations: tuk-tuk-tuk, kapkap-kap, haŭ-haŭ-haŭ, ach-ach-ach, o-jo-joj, o-ho-ho, o-cho-cho, u-cha-cha, tra-ta-ta, nu-i-nu, ta-ra-rach, ty-li-li, ciu-liu-liu, čyk-čyryk, šabultych, ku-klusklan. The accents are also distributed in a certain sequence here: túk-tuk-túk, káp-kap-káp, ó-jo-jój! The strongest syllable is always the last one, which is always stressed, but there is a clear stress on the first syllable, too. (In fact, the nature of accentuation of the first and the last syllables is different, which is especially noticeable on the example of such onomatopoeia as $i$-ho-hō!, where the voice goes up on the first syllable, and the syllable becomes stronger, while on the last syllable it becomes longer and stronger. But we abstract our minds from the nature of accents.) The second syllable, which is right in the middle, sounds as if it is not stressed at all. Even if we make a conscious effort, it is much more difficult to shift the stress to the second syllable than to the first 
one in a two-syllable composition. Thus we are witnessing the alternation of the intensity of pronunciation with formal identity of syllables, i.e., we get the rhythm that can be interpreted as trochaic. It is extremely important that it inevitably emerges outside of the opposition "verse/prose".

Now let us turn to longer combinations, trying to say them fluently, without any breaks. In order not to get confused with their number, you can record every single syllable on paper with a pencil. This time we have five syllables: $t u k$-tuk-

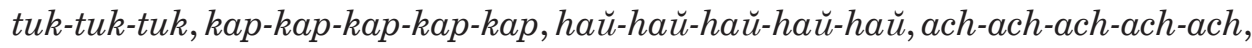
o-jo-jo-jo-joj! And once again, there is a strong accent at the beginning and at the end of a syntagma, and a less pronounced one in the middle: túk-tuk-túktuk-túk. We can hear a similar rhythm in the folk lullaby refrain: $\boldsymbol{a}^{\prime}-\boldsymbol{a}-a^{\prime}-a-\boldsymbol{a}^{\prime} / /$ $\boldsymbol{a}^{\prime}-a-a^{\prime}-a-\boldsymbol{a}^{\prime}$. In other words, there are three ictuses per five syllables. In $3-$ and 5 -syllable combinations stressed positions are distributed in a way that the first ictus always falls on the first syllable. It gives us a trochaic cadence, but any trochee can also be interpreted as a paeon, and under certain conditions also as an anapaest (see Paciupa 2014-2016, № 11: 20-23), i.e., meter is not an immanent property of the text, but a conventional scale. If exclamations and onomatopoeias are said without pauses, there are no deviations from the sequence described above. Exceptions may only occur when particles or suffixes are attached to exclamations, which, as a rule, are unstressed: avochci! nu-tka! ojeńki!, the Russian oy li!, etc. This exception proves the rule.

At the beginning of the twentieth century, Chudovskiy explained why this happens: "In a sense, I am ready to determine the most versified speech as the speech that is easy to say. Rhythmics is all about saving your voice" (Chudovskiy 1915: 83). Or, as contemporary phonetics teaches us: "The alternation of strong and weak stresses is more convenient than the vicinity of the ones with equal effect" (Kodzasov \& Krivnova 2001: 386). However, this is not merely the alternation, but the alternation within the limits of a certain syllabic structure, in which the trochee-type rhythm is inevitable under given conditions. The invariable presence of trochee in folklore is not the influence of literature, as it was assumed by Vostokov (1817), but rather the other way round. Beyli was right: "Its emergence should not necessarily be ascribed to the influence of literary verse" (Beyli 2001: 151). Some similarity to verse is also observed in the ontogenesis of speech: "It is still in the cradle, while not being able to talk yet, a baby who is eight or nine months old is happily uttering some rhythmical babbling" (Chukovskiy 2001 [1928]: 276). And it is trochee-type structures that are predominant: "Very boldly, without lengthy considerations, little children break down any kind of word form in order to secure the victory of their favorite rhythm" (ibid.: 285). 


\section{THE SYSTEM OF RHYTHMIC FORMS CODING}

So, the following structures are observed in exclamations and onomatopoeias the three stages of rhythm generation - a monad: $\mathbf{O}$ (one ictus); a diad: oO (two syllables and one ictus); a triad: OoO (three syllables and two ictuses), and

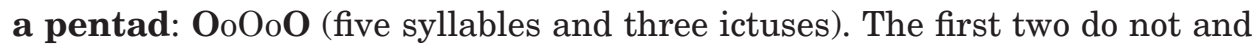
cannot contain within themselves any kind of rhythm measure - a rhythmicity (periodicity of some kind or recurrence, as Kvyatkovskiy would have put it). Only the last two are the minimum rhythm units with a 2 -syllable (weak ictuses) and a 4-syllable (strong ictuses) alternation range, or, in other words, the reification of a ritmema. Incidentally, a 3-syllable unit is not quite independent either, because it does not accommodate the full rhythmic cycle of the RAD: from the constant (as a strong ictus), bypassing the middle one - to the strong ictus, but only half of the cycle: from the constant - to the middle ictus. Tomashevskiy noticed the rhythmical dependence of commas - small colons (Tomashevskiy 1959: 23), while Kvyatkovskiy made a number of important conclusions for his theory on the basis of this phenomenon (Kvyatkovskiy 1966: 364, 96, 64).

Traditional folk verse comes down to the combinations of colons with 3 - and 5 -syllabic nuclei or goes up to them. This phenomenon is not only verified by the facts from Belarusian folklore. However, I will not decide on the generality of it and will refrain from further generalizations. It can only be pointed out in advance that certain exceptions are monosyllabic languages. In such languages, regardless of the nature of stress, syllable monads and diads serve as construction material: "The initial measure of the Vietnamese verse is a bar (tyet), which usually consists of two syllables (sometimes from three syllables or from one syllable). ... Syllable tones do not alternate one after another, but the tones of the last syllables in bars" (Yan 1976: 101). Obviously, a bar here is something equal to a foot if the number of syllables is taken into account, or even a smaller unit, while it is equal to a colon if the level is taken into account. In European languages, a verse cannot be made up of 1- or 2-syllable commas, because they agglutinate into larger colons, even in such literary contrivances as brachy-colons (see Kvyatkovskiy 1966: 64-65).

We can regard the sequence of structures oO (tuk-tuk) as the iamb, but it will not be an iamb, just like it is not an iamb in the Khmer language, which has expiratory accent, by the way. Feet are the integrants of colons, which are not divided by caesuras, like the latter, and are impossible to single out without ruining the word. The question arises as to what is primal - syllabic or accentual structures, trochees or triads? We assume that syllabic structures are primal, since even in diads that we have had a look at in the first run some kind of iamb could be observed. The trochee "disappears" in some other struc- 
tures of folk verse, too, if the constant is changing its position. Of course, it would be very interesting to observe how the syllabic structures in languages with very different prosodic characteristics, for example, with the left phrasal stress, behave, but such extensive work was never included in the range of our tasks. Nevertheless, we can claim that in exclamations, onomatopoeias, and reduplications of different kinds there are universals, along the lines of which folk verse is built up.

The discovery of rhythm universals as an invariant of a verse is changing the relations between verse and prose fundamentally. Prose, from now on, stops being the baseline, a norm, etc. If we abstract our mind from such anomalies as lipo- and hypermetria, rhythmical inversion, etc., it will be possible to describe the diversity of folk meters with the help of symbols. The suggested formula is an advancement of the digital encoding of A. Potebnya (see Potebnya 1884; for explanations Shtokmar 1952a: 71-76).

An elementary unit of a verse is a colon $\mathbf{k}$, its rhythmical invariant is a ritmema $\rho$. In folklore, all ritmemas come down to two archeritmemas with a 3- and 5-syllable nucleus. Without regard for clausula, we will record them as $\tilde{\boldsymbol{\alpha}}$ and $\tilde{\boldsymbol{\beta}}$, with the account of feminine clausula - as $\boldsymbol{\alpha}$ and $\boldsymbol{\beta}$, masculine clausula - as $\boldsymbol{\alpha}_{-\mathbf{1}}$ and $\boldsymbol{\beta}_{-1}$, and dactylic clausula - as $\boldsymbol{\alpha}_{+1}$ and $\boldsymbol{\beta}_{+1}$. The regularly occurring system of colons - period $\pi$, will be expanded in round brackets (), while the regular combination of periods - stropheme $\sigma$ - in square brackets [] (Fig. 1), just like the irregular combination of periods - strophoids $\mathbf{s}$, and a row of strophes or strophoids that make a text $\xi$ - in curly brackets \{\}. Colons that are smaller than 3 syllables virtually do not exist (see Kvyatkovskiy 1966: 364, 96; Tomashevskiy 1959: 23). However, 1- and 2-syllable commas are often used as the edging of colons (refrains and exclamations), i.e., as subritmemas: $\mathbf{\imath}$ and $\boldsymbol{v}$. In addition to heart-rending romances and the so-called guerrilla songs, regular meters are only observed in folklore in embryonal state, if any. Let us introduce designations for them as well: trochee as it is $\boldsymbol{\varepsilon}$; iamb o; paeons (as doublets $\boldsymbol{\varepsilon}$ and $\mathbf{o}$ ) - 1st $\dot{\mathbf{\eta}}$; 2nd $\dot{\boldsymbol{\omega}}$; 3rd $\mathbf{\eta}$; 4th $\boldsymbol{\omega}$; dactyl $\boldsymbol{\lambda}$; amphibrach $\boldsymbol{\mu}$; anapaest $\mathbf{v}$. The process of transformation of archeritmemas into literary meters remains outside of the scope of this research.

Within this system, $\boldsymbol{\alpha}$ and $\boldsymbol{\beta}$ are the basic units, and $\mathbf{\imath}$ is a minimal unit that is equal to a syllable. In some languages, for example, in monosyllabic $\mathbf{r}$ and v, obviously, belong to the set of basic elements (see Leang 1963; Yan 1976; Slovar' 1974: 127-130, 159). In Turkic languages, where stress is on the last syllable, the colons containing an even number of syllables represent an iambtype conglomeration $\boldsymbol{v}^{2}$, which, however, is easily linked to a trochee-type colon $\mathbf{a}_{-1}$ (see Korogly 1983: 304). Unlike Potebnya's system, this one encodes not only quantitative syllabic parameters, but also qualitative accentual ones - the 
location of the constant and the nature of the clausula - and, at the same time, it conveys the uniformity of the nature of folk verse, which, thus, comes down to combinations and variations of archeritmemas. As an example, I will have a look at the models of some typical strophes from the repertory of Belarusian folklore (words with inversion are marked in italics).

The most popular meter is 8 syllables, which can be observed among the inhabitants of all or almost all parts of the world (Bardavelidze 1975), for example, the Georgian high shairi, which is inclined towards a tetrameter trochee, and the formula is written down both in an expanded and in a short form - [(a $+\alpha)+(\alpha+\alpha)]=[2(\alpha+\alpha)]$ :

\section{Oj, u póli || za haróju \\ Rascie žýta || z liebiadóju}

(PK 1978: 56)

Owing to the abundance of masculine clausulae in the Belarusian language, an 8-syllable unit is often transformed into a 7-syllable one, which is also a frequent phenomenon in Turkic languages (see Akhmetov 1964: 95), while the structure of the nucleus does not change $-\left[\left(\alpha+\alpha_{-1}\right)+\left(\alpha+\alpha_{-1}\right)\right]=\left[\mathbf{2}\left(\alpha+\alpha_{-1}\right)\right]$ :

A na dvare | | snieh napáŭ, A malójčyk || z kania spáŭ (PK 1978: 73)

Another ancient meter is a 10-syllable unit with a 5-syllable colon, namely, its version with a masculine clausula: $\left[\left(\boldsymbol{\beta}_{-1}+\boldsymbol{\beta}_{-1}\right)\right]$, which is often observed in the Belarusian calendar-ritual poetry (it is inclined towards trochaic trimeter):

Dzie kaza nahój,

Tam žyta kapój

(ZP 1975: 375).

In East Slavic languages, owing to variable stress, the availability of long words - primarily, of full adjectives, verbs with a postfix -sia, and diminutivehypocoristic forms - the meters with dactylic clausulae, in particular, 10-syllable units, got widespread use $\left[\left(\boldsymbol{a}_{+1}+\boldsymbol{\alpha}_{+1}\right)\right]$ :

$$
\begin{aligned}
& \text { A Kaliádački, } \\
& \text { Bliny-ládački! } \\
& \text { (PZK 1992: 111) }
\end{aligned}
$$

At the end of the eighteenth and beginning of the nineteenth centuries, this 10-syllable unit was canonized as a "Russian meter" for the pasticcio of folklore. 
Sreznevskiy saw a proto-Slavic "epic meter" in it (Sreznevskiy 1959 [1950]: 71-72), but, in the light of the new data, dactylic clausulae outside of the borders of East Slavic languages is an atypical phenomenon (Beyli 2001: 148). It should be pointed out that a similar consistent pattern is also observed in the ontogenesis of a verse: among children, "dactylic rhymes hardly ever occur" (Chukovskiy 2001 [1928]: 276). Quite often, especially in calendar-ritual poetry, which, in comparison with lyric poetry, is less regulated, colons $\boldsymbol{\beta}_{-1}$ and $\boldsymbol{\alpha}_{+1}$ can co-exist in one text: $\boldsymbol{\beta}_{-1}=\boldsymbol{\alpha}_{+1}$, and difference between them becomes prominent only when they are said out loud.

And, finally, one more ancient and simple meter that is widespread not only in Slavic languages, but also far beyond its limits - a 12 -syllable unit with a 6 -syllable colon and a 5-syllable nucleus $[(\boldsymbol{\beta}+\boldsymbol{\beta})+(\boldsymbol{\beta}+\boldsymbol{\beta})]=[2(\boldsymbol{\beta}+\boldsymbol{\beta})]$, which is also inclined towards trochaic trimeter and is popular in literature:

Holub na čaréšni,

Halubka na víšni.

Skažy moj miliéńki,

Što ŭ ciabie na mýsli?

(Fedecki 1992: 27)

More complex formations emerged later on, and their areals were no longer all-encompassing. One of the most widespread complex meters is a 14-syllable unit, which is a combination of the meters described above (it is inclined towards the combination of trochaic trimeter and tetrameter), is typical in folk lyrics, and has exerted an immense effect on literary verse $[(\boldsymbol{\alpha}+\boldsymbol{\alpha}+\boldsymbol{\beta})+(\boldsymbol{\alpha}+$ $\alpha+\beta)]=[2(\alpha+\alpha+\beta)]$ :

Siadzić hólub || na dubóčku,

Halubka na višni.

- Skažy, skažy, || dziaǔčyníca,

Što ŭ ciabie za mýsli?

(PK 1978: 104)

An asymmetrical strophe $\left[\left(\boldsymbol{\beta}_{-1}+\boldsymbol{\beta}_{-1}\right)+\left(\boldsymbol{\alpha}+\boldsymbol{\alpha}+\boldsymbol{\beta}_{-1}\right)\right]$ is a very interesting and even somewhat obscure phenomenon:
A ŭ poli viarbá,
Pad viarboj vadá.
Tam chadzíla, || tam huliála
Dzieǔka maladá
(PK 1978: 60) 
Its modification with feminine clausulae is also typical: $[(\boldsymbol{\beta}+\boldsymbol{\beta})+(\boldsymbol{\alpha}+\boldsymbol{\alpha}+$ $\boldsymbol{\beta})$ ]. It is widespread in West Slavic folk verse (Marčok 1980: 135) as well as in Lithuanian ones (Sauka 1980: 9, 21). It is not used in literature, except for one pasticcio done by Maksim Bahdanovič, which is known to us.

The meters where colons stand in contrast are less typical. Among them, the most popular is the $\boldsymbol{\beta}+\boldsymbol{\alpha}$ type, which is represented by numerous versions, for example, a 10-syllable unit $\left[\left(\boldsymbol{\beta}_{+1}+\alpha\right)+\left(\beta_{+1}+\alpha\right)\right]=\left[2\left(\beta_{+1}+\alpha\right)\right]$ :

\section{U niadzieĺku ránieńka || na zarý \\ Ščabiatala lástaŭka || na mory}

(PK 1978: 50)

The invert correlation of the short and long colons is observed in the meter that is popular in the study of poetry and folklore studies, owing to the attention paid to it by Trubetskoy and Yakobson. It is well-known as a Serbian "deseterets", which is a basic meter in the South Slavic epic. It is current in the West Slavic area as well as among the Lithuanians and Hungarians (Gasparov 2003: 203), and it is quite often used in Belarusian folk lyrics $-[(\boldsymbol{\alpha}+\boldsymbol{\beta})+(\boldsymbol{\alpha}+$ $\beta)]=[2(\alpha+\beta)]$ :

\section{Za tumánam || ničoha nie vídna, Tolki vídna || dúba zielianóha (PK 1978: 80)}

For the first time, this form, along with the "Russian meter", was put forward for the part of the proto-Slavic epic verse by Sreznevskiy, and his idea was picked up by Trubetskoy and Yakobson (Trubetskoy 1987: 356-358; Yakobson 1987: 39-47). The latter even "derived" this meter from the Indo-European 8-syllable unit, and, in turn, he "derived" bylina verse from the "derived" 10-syllable unit. Just like in the case of the Russian meter, Sreznevskiy and his followers were incorrect. I will not cite valid criticism against "deriving" bylina verse from "deseterets", put forward by Zaytsev (1995), but will only point out that the division of meters into epic and lyrical ones in a long-term perspective is inefficient and is not supported by any evidence. There are no reasons to believe that proto-Slavic epos has ever existed, and if it did, the epic traditions that we know about, i.e., Serbian, Russian, and Ukrainian, seem not to be linked to each other. Calendar-ritual poetry provides a more reliable material for reconstructing the ancient verse.

Interestingly enough, in some songs of the Belarusian calendar cycle there is a strophe consisting of colons used in "deseterets", but more complex in composition, with a double 6 -syllable colon and a repetition of a 4-syllable colon at the end of the period as a refrain $-\left[(\boldsymbol{\alpha}+\boldsymbol{\beta}+\boldsymbol{\beta})+{ }^{1} \boldsymbol{\alpha}\right]$ : 


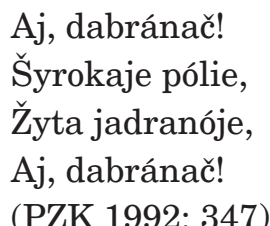

I have not studied well enough the area where this strophe is widely used, but mainly it is linked to the north-eastern part of Belarus.

As for the Russian bylina verse, it possibly dates back to the ancient Slavic 12-syllable $\boldsymbol{\alpha}+\boldsymbol{\alpha}+\boldsymbol{\alpha}$ (in the Turkic tradition - as an 11-syllable $\boldsymbol{v}^{2}+\boldsymbol{v}^{2}+\boldsymbol{\alpha}_{-1}$ ). Here is an example of the strophe where the connection of a 12-syllable unit with an 8-syllable one $-[(\boldsymbol{\alpha}+\mathbf{\alpha}+\mathbf{\alpha})+(\boldsymbol{\alpha}+\mathbf{\alpha}+\mathbf{\alpha})]=[\mathbf{2}(\boldsymbol{\alpha}+\mathbf{\alpha}+\mathbf{\alpha})]$ can be observed:

Viasna krásna, || viasna krásna || nastupáje, Vadoj lúhi, || vadoj lúhi || zaliváje...

(PZK 1992: 181)

If we leave out the repetition of the first colon, we get a typical 8-syllable unit: Viasna krásna / / nastupáje. Let us compare the same transaction in the Turkic language: "It is enough to leave out the first four syllables without detriment to sense, and we are getting a verse consisting of seven syllables" (Korogly 1983: 303).

Veselovskiy (1989: 186) said that epos was genetically linked to lamentations, and Yakobson also stressed this connection in every particular tradition, mainly, in the Serbian and Russian traditions (Yakobson 1987: 39-40). All the more amazing is that he was trying to forcibly narrow down all of those different traditions to a single imaginary source. As for the verse of the Russian lamentations, it lost caesura; after having been modified this way, it started resembling a paeon or an alternating trochee. Loss of caesurae has led to the transformation of the three archeritmemas into a hyperritmema with an 11-syllable nucleus: $\boldsymbol{\alpha}+\boldsymbol{\alpha}+\boldsymbol{\alpha} \rightarrow \boldsymbol{\psi}$. Here is an example of a Russian lamentation where the particle $\partial a$ (in square brackets) enables us to partially trace the "stitches" of the original colons:

Iz-pod réchen'ki plyvét [da] sera útushka, Eta útushka plyvét [da] potikhóshen'ku, Ona khóbody dayét [da] pomaléshen'ku, Goloskóm ona zhupít [da] zhalobnéshen'ko...

(Agreneva-Slavyanskaya 1896: 9-10)

Language places huge pressure on the universals of the rhythm, which leads to the modification of original meters. For example, the 5-syllable colon described 
above in versions $\boldsymbol{\beta}_{-1}$ and $\boldsymbol{\alpha}_{+1}$ has a third version, too, with a shift of constanta to the next-to-last syllable and a formation of a 4-syllable nucleus. Obviously, this pressure was exerted by the Polish language. In this case, there is simply no space for a trochee, and we are getting something like a dactyl as an invariant ( $\left.\mathbf{O o o O}_{0}\right)$ and an iambic dimeter as a variant (oOoOo). Let us designate this dactyl-type ritmema with a ${ }^{\lambda} \boldsymbol{\rho}$; the strophe formula will be $\left[\left({ }^{\lambda} \boldsymbol{\rho}+{ }^{\lambda} \rho\right)+\left({ }^{\lambda} \rho+\right.\right.$ $\left.\left.{ }^{\lambda} \rho\right)\right]=\left[2\left({ }^{\lambda} \rho+{ }^{\lambda} \rho\right)\right]:$

\author{
Dažali žýta || až da daróhi, - \\ Ǔ našaha pána || borzdyja nóhi. \\ Nie žaluj, páni, || bielaha sýru, - \\ Dasć Boh ^ páni || dobraha sýna \\ (BNP 1959: 14)
}

The fate of this meter in folklore and literature is curious indeed (see Paciupa 2014: 154-156). I will not rest upon it for too long, so let us turn to generalizations and outline the problems that crop up in the field of folklore poetry studies in light of the data cited above.

\title{
PERSPECTIVES
}

Firstly, it should be pointed out that binary and trinary rhythmical formations are not limited to the level of syllables, and versified speech cannot be reduced to physiology. "In poetry, measure is not dependent on breathing, it follows the rhythm coming from the brain, not from the lungs" (Terner \& Poppel' 1995: 85). The universals of the rhythm can encompass more complex formations, being included into each other just like nesting dolls. In this case, verse is just one of the manifestations of mental rhythms, or, as it has been pointed out by Alandskiy, "meter is an individual case of a larger psychological phenomenon" (Alandskiy 1875: 81). It should be stressed here that we are nowhere near postulating a "triadic" etc. model of nature, but, on the opposite, we believe that in the course of the cognitive process, an object is forcibly rhythmicized by our brain, which is indisposed to notice the force it is applying. In binary and trinary rhythms, not only the syllables in colons are arranged, but also colons in periods, motifs in plots, etc. A transition to a higher level of organization can be written down by the following formulae: $\boldsymbol{v} \times \mathbf{x}=\mathbf{Y} ; \boldsymbol{\alpha} \times \mathbf{x}=\mathbf{A}$, or $\mathbf{v}^{\mathbf{x}}=\mathbf{Y}$; $\mathbf{a}^{\mathbf{x}}=\mathbf{A}$. The condition of the most ancient poetic text can be represented as $* \boldsymbol{\xi}=*^{\mathbf{n}}$, where $\mathbf{n}=2,3$.

The second important aspect that we should pay attention to is related to the perspectives of the development of the studies of poetry. The discovery of 
rhythmical universals allows us to take a fresh look at verse in terms of time and spatial aspects. While reconstructing the ancient conditions of verse, we should abandon prose-centeredness, where prose is perceived as the norm and verse is regarded as anomaly, and the whole history of verse is seen as a process of the "harmonization of prose". With such an attitude in mind, conclusions are made without due consideration of the conditions of the language, and more precisely, on the basis of one or another model of speech that is developed enough. Verse is dependent on the prosodic setting, in which universals are actualized. Another error made during reconstruction is the projection of the rules of development of literary verse onto folk verse. The revolutionary conclusions made by Perry and Lord are not taken into consideration: "An oral piece of writing is not created for performing it, it is created in the process of performing" (Lord 1994: 24). In folk verse, there is no loss of rhythm that would not be compensated for at the moment of its reproduction. But we should bear in mind that, in addition to rhythm universals, there are also some rhythmical stereotypes that keep migrating in the process of cultural exchange until they collide with a specific prosody.

Penetration into the layers of time is unthinkable without mapping the geography of meters. Instead of pinning the labels, such as "accentual" and "syllabic", and wandering into the maze of statistics of inter-ictus intervals, which is pointless if there is no clear vision of an invariant, instead of endless arguments about theories, each one of which is right in its own way, the study of poetry should eventually resort to the cataloguing of folk verse with due consideration of the areas of distribution of this or that form within a national and international scale, with a perspective of tracing isoglosses. The essential support within the context of comparative metrics can be provided by comparative studies of exclamations and onomatopoeias, which was highlighted by Jakobowski (see Jakobowski 1891). We are distancing ourselves from Bowwow and Pooh-pooh theories, but in interjections and onomatopoeias we see the enclaves, in a similar way to earlier stages of cultural development, which still contain features hidden in more complex language subsystems.

\section{ACKNOWLEDGEMENTS}

The article was written as part of a project financed by the Foreign Ministry of Estonia through the Developmental Cooperation Programme (66-2015-A). 


\section{NOTES}

1 Herein the term syntagma should be seen as a "fragment of a speech chain, a part of a phrase" (i.e., a syntagma according to Shcherba, not according to de Saussure).

2 As for the term line, which is sometimes promoted as the underlying category of verse, it is irrelevant to folk verse: firstly, it can accommodate one colon or the entire period, and, secondly, one way or another, it is an interpretation of a folklorist.

3 Every single letter denotes a syllable: a small letter 'o' means an unstressed syllable; a capital letter ' $O$ ' means a slightly stressed syllable, a capital bold letter 'O' means strongly stressed syllable; $x$ means a varying number $(0-1-2 \ldots)$ of clausula syllables; two vertical lines || mean a caesura; slash and backslash characters $/ \backslash$ mean a leymah.

4 This term was first used by Yanakiev (1960: 89-95), but with a completely different meaning.

5 Neither a clausula nor an anacrusis are included in a nucleus, according to Yanakiev (1960: 95), or in a metric sequence, according to Tomashevskiy (1923: 46), which, in my opinion, is inappropriate, since everything that is happening to the left of the constant is a single whole field of rhythmic strain. If the nucleus does not include the anacrusis, the notion of the nucleus will lose its explanatory power.

6 Recently, interest in similar structures among philosophers has been revived. For example, a huge amount of culturological material has been collected and generalized in a book by Borzova (2007). But, unfortunately, philosophical research in this field quite often indulges in essentialism and mysticism.

\section{REFERENCES}

Agreneva-Slavyanskaya, Ol'ga 1896 [1887]. Opisanie russkoi krest'ianskoi svad'by s tekstom i pesniami: obriadovymi, golosil'nymi, prichital'nymi i zavyval'nymi. [Description of Russian Farmers' Wedding with the Text and Songs: Ritual, Crying, Wailing, Lamentative.] In 3 vols. Vol 2. Opisanie vsekh obriadov svadebnogo dnia. [Description of the Wedding Day Rituals.] Tver': n.p.

Akhmetov, Zaki 1964. Kazakhskoe stikhoslozhenie: Problemy razvitiia stikha $v$ dorevoliutsionnoi $i$ sovremennoi poezii. [Kazakh Versification (Problems of Verse Development in Prerevolutionary and Modern Poetry).] Alma-Ata: Nauka.

Alandskiy, Pavel 1875. Poeziia kak predmet nauki. [Poetry as a Subject of Science.] Universitetskie izvestiia, No. 2, Chast' neofitsial'naya, pp. 71-129.

Bardavelidze, Dzhondo 1975. K izucheniiu drevneishikh stikhotvornykh form. [To the Study of the Most Ancient Poetic Forms.] In: N. Kravtsov (ed.) Problemy fol'klora. Moscow: Nauka, pp. 191-197.

Beyli, Dzheims 2001. Izbrannye stat'i po russkomu narodnomu stikhu. [Selected Articles on Russian Folk Verse.] Moscow: Iazyki russkoi kul'tury.

BNP 1959 = Bielaruskija narodnyja piesni. [Belarusian Folk Songs.] Minsk: Dziaržaŭnaje vydaviectva BSSR. 
Bondarko, Liia \& Verbitskaia, Liudmila \& Gordina, Mirra 1991. Osnovy obshchei fonetiki: Uchebnoe posobie. [Foundations of General Phonetics: Manual.] St. Petersburg: Izd-vo Sankt-Peterburgskogo universiteta.

Borzova, Elena 2007. Triadologiia. [Triadology.] St. Petersburg: SPbGUKI.

Chudovskiy, Valerian 1915. Neskol'ko myslei k vozmozhnomu ucheniiu o stikhe (s primernym razborom stikhoslozheniia v I glave "Evgeniia Onegina"). [Several Thoughts about the Possibility of Verse Teaching (On the Example of Versification Analysis in the First Chapter of "Evgeniy Onegin").] Apollon, No. 8-9, pp. 55-95. Available at http://www.v-ivanov.it/apollon/apollon_1915_08-09.pdf, last accessed on 28 May 2018.

Chudovskiy, Valerian 1917. Neskol'ko utverzhdenii o russkom stikhe. [Several Statements about Russian Verse.] Apollon, No. 4-5, pp. 58-69. Available at http:// www.v-ivanov.it/apollon/apollon_1917_04-05.pdf, last accessed on 28 May 2018.

Chukovskiy, Korney 2001 [1928]. Ot dvukh do piati. [From Two to Five.] Sobranie sochinenii $v 15$ t. Vol. 2. Moscow: Terra \& Knizhnyi klub. Available at http:// www.chukfamily.ru/kornei/prosa/knigi/onetofive, last accessed on 28 May 2018.

Dubenskiy, Dmitriy 1828. Opyt o narodnom russkom stikhoslozhenii. [Experience of Folk Russian Versification.] Moscow: Universitetskaia tipografiia.

Fedecki, Ziemowit 1992. Cioplyja viečary... dy chalodnyja ranki... czyli Co śpiewano $w$ Feliksowie: (bielaruskija narodnyja piesni Lidskaha pavietu). [Belarusian Folk Songs of Lida District.] Warszawa: Białoruskie towarzystwo społeczno-kulturalne.

Gasparov, Mikhail 2003. Ocherk istorii evropeiskogo stikha. [Essay of European Verse History.] Moscow: Fortuna Limited.

Gasparov, Mikhail \& Skulacheva, Tat'iana 2004. Stat'i o lingvistike stikha. [Articles about Linguistics of Verse.] Moscow: Iazyki slavianskoi kul'tury.

Ivanov, Vyacheslav \& Toporov, Vladimir 1963. K rekonstruktsii praslavianskogo teksta. [To the Reconstruction of Proto-Slavic Text.] Slavianskoe Iazykoznanie: Doklady sovetskoi delegatsii. V Mezhdunarodnyi S"ezd Slavistov (Sofiia, sentiabr' 1963). Moscow: Izdatel'stvo AN SSSR, pp. 88-158. Available at http://www.pseudology. org/Literature/5_Siezd_Slavyanskoe_Yazykoznanie_1963a.pdf, last accessed on 28 May 2018.

Jakobowski, Ludwig 1891. Die Anfänge der Poesie: Grundlegung zu einer realistischen Entwickelungsgeschichte der Poesie. Dresden \& Leipzig: E. Pierson's Verlag. Available at https://archive.org/details/dieanfngederpoe01jacogoog, last accessed on 28 May 2018.

Kodzasov, Sandro \& Krivnova, Ol'ga 2001. Obshchaia fonetika: Uchebnik. [General Phonetics: Textbook.] Moscow: Izd-vo Rossiiskogo gosudarstvennogo gumanitarnogo universiteta.

Korogly, Khalyk 1983. Vzaimosviazi eposa narodov Srednei Azii, Irana i Azerbaidzhana. [Interconnections of Eposes of Middle Asia, Iran and Azerbaijan Peoples.] Moscow: Nauka.

Kulakovskiy, Yulian 1890. K voprosu o russkom narodnom stikhe. [To the Issue of Russian Folk Verse.] Chteniia $v$ istoricheskom obshchestve nestora letopistsa. Vol. 4. Kiev: Tipografiia V.I. Zavadszkago, pp. 1-3. Available at http://history.org. ua/LiberUA/ChtenIONL4_1890/ChtenIONL4_1890.pdf, last accessed on 28 May 2018. 
Kvyatkovskiy, Aleksandr 1966. Poeticheskii slovar'. [Poetical Vocabulary.] Moscow: Sovetskaia entsiklopediia.

Kvyatkovskiy, Aleksandr 2008. Ritmologiia. [Rhythmology.] St. Petersburg: INAPRESS \& Izdatel'stvo Dmitrii Bulanin.

Leang, Khap An 1963. Elementy kkhmerskogo stikhoslozheniia. [Elements of Khmer Versification.] Narody Azii i Afriki, Vol. 6, pp. 130-139.

Lord, Al'bert 1994. Skazitel'. [Storyteller.] Transl. and commented by Iu. Kleiner \& G. Levinton. Moscow: Izdatel'skaia firma Vostochnaia literatura RAN.

Marčok, Viliam 1980. Estetika a poetika l'udovej poézie. [Aesthetics and Poetics of Folk Poetry.] Bratislava: Tatran.

Paciupa, Jury 2004. Strala Zienona: Rytmalahičny traktat. [Zenon's Arrow: Rhythmological Tractate.] Arche, Vol. 5, pp. 262-319.

Paciupa, Jury 2014. Rytmavyja struktury bielaruskaj narodnaj piesni: Podstupy da prabliemy (na materyjalie v. Damejki Lidskaha rajona). [Rhythmic Structures of Belarusian Folk Song: Approach to the Issue, on the Data of Dameiki Village, Lida District).] Bielaruski falklor: Materyjaly i dasliedavanni: Zbornik navukovych prac. Minsk: Bielaruskaja navuka, Vol. 1, pp. 137-161.

Paciupa, Jury 2014-2016. Zakony rytmu i pryroda vykličnikaŭ. [Laws of Rhythm and Nature of Interjections.] Rodnaje slova, 2014: Vol. 8, pp. 23-26; Vol. 9, pp. 22-25; Vol. 11, pp. 19-24; 2015: Vol. 1, pp. 29-34; Vol. 4, pp. 25-31; 2016: Vol. 2, pp. 18-23.

Paciupa, Jury 2016. Vieršavannie ŭ zamovach: Pavodlie materyjalaŭ Viciebščyny i Hrodzienščyny. [Versification in Spells According to the Materials of Vitsebsk and Hrodna Regions.] Bielaruski faĺlklor: Materyjaly $i$ dasliedavanni: Zbornik navukovych prac. Minsk: Biel. navuka, Vol. 3, pp. 146-197.

PK 1978 = Piesni pra kachannie. [Songs about Love.] Minsk: Navuka i technika.

Polivanov, Yevgeniy 1963. Obshchii foneticheskii printsip vsiakoi poeticheskoi tekhniki.

[General Phonetic Principle of Any Poetical Technique.] Voprosy iazykoznaniia, Vol. 1, pp. 99-112. Available at http://www.ruslang.ru/doc/voprosy/voprosy1963-1. pdf, last accessed on 29 May 2018.

Potebnya, Aleksandr 1884. Obzor poeticheskikh motivov koliadok i shchedrivok. I: Razmer. [Overview of Poetical Motifs of Carols and Pre-New Year Songs. I: Meter.] Russkii filologicheskii vestnik, Vol. 11, No. 1, pp. 1-32.

Propp, Vladimir 2001. Morfologiia volshebnoi skazki. [Morphology of the Fairytale.] Moscow: Labirint.

PZK 1992 = Paezija bielaruskaha ziemliarobčaha kaliendara. [Poetry of Belarusian Agricultural Calendar.] Minsk: Navuka i technika.

Samsonov, Dormidont 1817. Kratkoe rassuzhdenie o russkom stikhoslozhenii. [Brief Speculation about Russian Versification.] Vestnik Evropy, Vol. 15-16, pp. 219-253.

Sauka, Leonardas Yonovich 1980. Stikhoslozheniye litovskikh narodnykh pesen. Avtoreferat dissertatsii na soiskanie uchenoi stepeni doktora filologicheskikh nauk. [Versification of Lithuanian Folk Songs. Author's Abstract of the Dissertation for the Scientific Degree of PhD.] Vilnius: n.p.

Shtokmar, Mikhail 1952a. Issledovaniia v oblasti russkogo narodnogo stikhoslozheniia. [Research in the Field of Russian Folk Versification.] Moscow: Izd-vo Akademii nauk SSSR. 
Shtokmar, Mikhail 1952b. O stikhovoi sisteme Maiakovskogo. [About the Verse System of Mayakovsky.] Tvorchestvo Maiakovskogo: Sbornik statei. Moscow: Izdatel'stvo Akademii nauk SSSR, pp. 258-312.

Slovar' $1974=$ Slovar' literaturovedcheskikh terminov. [Dictionary of Terms in Literature Studies.] Edited \& compiled by L. Timofeev \& S. Turaev. Moscow: Prosveshchenie.

Sreznevskiy, Izmail 1959 [1850]. Mysli ob istorii russkogo iazyka (chitano na akte Imperatorskogo S. Peterburgskogo universiteta, 8-go fevralia 1849 goda). [Thoughts about the History of the Russian Language (Reported at the Sitting of Imperial St. Petersburg University on 8 February 1849).] Moscow: Gosudarstvennoe uchebno-pedagogicheskoe izdatel'stvo.

Taranovskiy, Kirill 2000. O poezii $i$ poetike. [About Poetry and Poetics.] Compiled by M. Gasparov. Moscow: Iazyki russkoi kul'tury.

Taranovskiy, Kirill 2010. Russkie dvuslozhnye razmery: Stat'i o stikhe. [Russian Disyllabic Meters: Articles about Verse.] Moscow: Iazyki slavyanskoi kul'tury.

Terner, Frederik \& Poppel', Ernst 1995. Poeziia, mozg i vremia. [Poetry, Brain and Time.] Krasota i mozg: Biologicheskie aspekty estetiki. Moscow: Mir, pp. 74-96.

Timofeyev, Leonid 1958. Ocherki teorii i istorii russkogo stikha. [Essays of Russian Verse Theory and History.] Moscow: Gosudarstvennoe izdatel'stvo khudozhestvennoi literatury.

Timofeyev, Leonid 1987. Slovo v stikhe: Monografiia. [Word in Verse: Monograph.] Moscow: Sovetskii pisatel'.

Tomashevskiy, Boris 1923. Russkoe stikhoslozhenie: metrika. [Russian Versification: Metrics.] St. Petersburg: Izdatel'stvo Akademiia.

Tomashevskiy, Boris 1959. Stikh i iazyk: Filologicheskie ocherki. [Verse and Language: Philological Essays.] Moscow \& Leningrad: Gosudarstvennoye izdatel'stvo khudozhestvennoi literatury.

Trediakovskiy, Vasiliy 2002. Sposob k slozheniiu rossiiskikh stikhov, protiv vydannogo v 1735 gode ispravlennyi i dopolnennyi. [The Way to Russian Versification, Corrected and Supplemented Edition of 1735.] In: A. Ranchin \& V. Korovin (comps.) Kritika XVIII veka. Moscow: Olimp \& AST, pp. 109-147.

Trubetskoy, Nikolay 1987. Izbrannye trudy po filologii: Perevody. [Selected Works on Philology: Translations.] Moscow: Progress.

Tudenov, Gunga 1958. Buriatskoe stikhoslozhenie: ritmicheskaia organizatsiia buriatskikh stikhov. [Buryat Versification: Rhythmic Organization of Buryat Verses.] Ulan-Ude: Buriatskoe knizhnoe izdatel'stvo.

Veselovskiy, Aleksandr 1989. Istoricheskaia poetika. [Historical Poetics.] Moscow: Vysshaia shkola.

Vostokov, Aleksandr 1817. Opyt o russkom stikhoslozhenii. [An Experience of Russian Versification.] St. Petersburg: Morskaia Tipografiia.

Yakobson, Roman 1923. O cheshskom stikhe: preimushchestvenno v sopostavlenii s russkim. [About Czech Verse Mainly in Comparison with the Russian One.] Moscow: Gosudarstvennoe izdatel'stvo.

Yakobson, Roman 1987. Raboty po poetike: Perevody. [Works on Poetics: Translations.] Moscow: Progress. 
Yanakiev, Miroslav 1960. Bŭlgarsko stikhoznanie. [Bulgarian Versification.] Sofia: Nauka i izkustvo.

Yan, K. 1976. O kharaktere metricheskoi sistemy v'etnamskogo stikhoslozheniia. [About the Character of the Metric System of Vietnamese Versification.] In: Souremennaia literatura zarubezhnogo Vostoka. Tashkent: n.p., pp. 98-110.

Zaytsev, Aleksandr 1995. Stikh russkoi byliny i praindoevropeiskaia poeziia. [Verse of Russian Epic and pro-Indo-European Poetry.] In: T. Novichkova (ed.) Russkii fol'klor. Vol. 28: Epicheskie traditsii. St. Petersburg: Nauka, pp. 198-205.

ZP 1975 = Zimovyja piesni: kaliadki $i$ ščadroǔki. [Winter Songs: Carols and Pre-New Year Ones.] Minsk: Navuka i technika. 


\title{
PATRIOTISM AND LOVE IN THE CONTEXT OF THE ESTONIAN WESTERN DIASPORA
}

\author{
Triinu Ojamaa \\ Estonian Literary Museum \\ e-mail: triinu.ojamaa@folklore.ee
}

\begin{abstract}
The article focuses on the love Estonians abroad have for their country of origin, compatriots, and people with different ethnic backgrounds. The research material consists of interviews, essays, and two novels. The interviews have mainly been collected from the Second World War refugees and their descendants in Canada, the USA, Australia, and Europe. The essays include immigrants' thoughts and feelings toward Estonia from the time of the restoration of the Republic of Estonia's independence onward. Elin Toona's novel Sipelgas sinise kausi all (The ant under the blue bowl) and Enn Nõu's novel Ma armastasin rootslast ehk Sollefteå suvi (I loved a Swede or summer in Sollefteå) are based on the authors' personal life experience in exile and reflect the refugees' attitudes toward Estonia as well as their host country. Based on the listed material, the article discusses the following issues: What are the sources of diaspora Estonians' patriotic feelings? How do the older diaspora generations teach the youth to love Estonia? Can the love for Estonia be unified with the love toward a non-Estonian?

The research revealed that the descendants of the refugees love Estonia as their ancestors' homeland and the source of cultural heritage. For those who have never lived in Estonia the country may take on the connotation of a fairytale land. Retelling of memoirs by older generations about their lives in Estonia before the Second World War has still an important role in generating a sense of patriotism toward Estonia. At the beginning of the exile period, literature also took on the role of supporting patriotic upbringing; later on this function waned.

The analyzed material points to changes in the attitudes of diaspora Estonians. During the post-war years, simultaneous love for Estonia and non-Estonians may have caused conflict situations as the general belief in the community was that mixed marriages threatened the sustainability of the Estonian diaspora. The younger generations as well as Estonians who left the homeland during the independence period starting from 1991 have a more multicultural attitude: they believe that mixed marriages and connectedness to some other culture do not limit their positive feelings toward Estonia.
\end{abstract}

Keywords: Estonia, Estonian Western diaspora, exile literature, love, mixed marriages, patriotism 


\section{INTRODUCTION}

The feelings of patriotism immigrants experience toward their host countries in Europe and elsewhere are coming into the realm of interest in diaspora studies. The rise of this issue is partially the result of escalating immigration problems encountered in the world today. For example, in their comparative study about host country patriotism among European immigrants, Tim Reeskens and Matthew Wright (2014) attempt to find out whether immigrants feel included or excluded in new situations and what contextual elements might influence them to express love and pride toward their host country. Qianqian Li's (2015) study on becoming American demonstrates how the applicants for naturalization learn American values and the reasons to be patriotic. Aune Valk, Kristel KaruKletter and Marianna Drozdova's (2011) study about Estonian open identity sets a goal to find the aspects of the Estonian national identity that would be acceptable to all ethnic groups in Estonia. The study also allows one to conclude which aspects Russian-speaking minority groups could use to build their own sense of Estonian patriotism and which aspects would serve as barriers.

In the current article I define patriotism as love of one's country and culture, identification with them, and special concern for their well-being as well as that of one's compatriots. In the context of the Estonian diaspora group, patriotism is connected to their ethnic identity. According to some authors, patriotism and loyalty can be regarded as synonymous. There undoubtedly exist certain ties between patriotism and loyalty. Nevertheless, in the current study I keep these two terms apart: I define loyalty as faithfulness to the state which is connected to one's civic identity. The current study passingly touches on the topic of loyalty; however, it focuses on diaspora Estonians' love for their country of origin (patriotism) and romantic love for compatriots and those of other ethnic backgrounds.

The article discusses the following issues: (1) What are the sources of diaspora Estonians' patriotic feelings? (2) How do the older diaspora generations teach the youth to love Estonia? (3) Can the love for Estonia be unified with the love toward a non-Estonian? These questions will not lose their relevance for as long as diaspora communities exist and develop, or at least until younger multicultural generations and new immigrants join them, whose attitudes toward their homeland have been developed on the basis of their own specific experiences. 


\section{RESEARCH MATERIAL AND METHOD}

The main research material consists of 52 semi-structured interviews which were conducted with representatives of the Estonian Western diaspora in Canada, USA, Australia, and Europe. The conversations with the interviewees took place in Estonian. The interviews were collected in 2008-2012 as part of the project "Perspectives of music in constructing the Estonian open identity". The collection has been supplemented with new interviews from 2014-2016, collected within the framework of the project "Formal and informal networks of literature based on sources of cultural history".

The interviewees are divided into two groups: the old-diaspora group (refugees of the Second World War and their descendants), and the new-diaspora group (Estonians who left the homeland at the end of the Soviet occupation or after the restoration of Estonia's independence in 1991).

The interviews touched on the following topics: What kind of relationship does the interviewee have with Estonia and Estonian culture (emphasis on music)? What are the criteria for being a "proper" Estonian? The main characteristics that seem to define a "proper" Estonian have been described by Triinu Ojamaa and Kristel Karu-Kletter (2014: 149): “A 'proper' Estonian is someone who speaks Estonian, feels he or she is Estonian, loves Estonia, has Estonian heritage, was born or lives in Estonia, shares a common history and culture with the other Estonians, is hard-working and loves music." The current article provides a more detailed analysis of the topic that arose from the interviews surrounding the opinions on how "proper" Estonians love Estonia.

As additional material, I used two collections and two novels that deal with topics similar to those of the semi-structured interviews. The collection Rändlindude pesad (The nests of migratory birds: Estonians' life stories abroad (Kirss 2006)) contains 12 life story interviews recorded with Estonians in Canada in 2000. The interviews include discussions about what it means to be an Estonian outside of Estonia. In the context of this article, these interviewees belong to the old-diaspora group. The collection titled Eesti ustest - sisse, välja (In and out of Estonia's doors: Speeches, articles, and essays (Käpp et al. 2013)) contains 14 essays collected during the Estonian President's literary collection campaign in 2011, 11 of which were written by people who had left Estonia and moved to the West after the restoration of Estonia's independence (in the context of the current article, they belong to the new-diaspora group). The authors of 3 essays represent the old-diaspora group. The essays describe the authors' attitudes toward Estonia and discuss the likelihood of their returning to their homeland.

The concept of generation used in this study is based on Karl Mannheim's work (1953 [1952]). In the context of the current article, a cohort who lives 
or has lived in similar conditions is considered a generation. They have experienced similar social changes and, as a result, certain similarities can be seen throughout their lives. The old-diaspora group began forming in the mid1940s and now includes three adult generations. The first generation consists of refugees who were born and received their education in Estonia; their views and attitudes have primarily been shaped within the surroundings of their original homeland. The second generation includes the children who traveled along with their refugee parents and those born in exile; they were raised and received their education outside of Estonia. The third generation includes the children of the second generation. The beliefs and attitudes of the second and third generations were shaped by the host country's sphere of influence.

For the analysis of the new-diaspora group, the focus is on the first generation. This group has existed for about 25 years and the second generation is just beginning to reach adulthood today. As in the old-diaspora first generation, the first generation of the new-diaspora group includes those who were born and received their education in Estonia, although in a different social-political context. However, the new-diaspora group's departure from Estonia has instead been voluntary (often for financial reasons) and therefore, less of a traumatic experience than the flight of the refugees.

All of the interviews and essay excerpts below have been given symbols: $\mathrm{O}=$ old-diaspora group; $\mathrm{N}$ = new-diaspora group; I, II, III = I, II or III diaspora generation respectively; $\mathrm{M}=$ male interviewee; $\mathrm{F}=$ female interviewee. In the collection Rändlindude pesad, Kirss (2006: 648) has criticized the three generations principle, in which the boundaries of the generations are based on being born in Estonia or in exile. In the analysis of the interviews, Kirss uses the term sillapõlvkond (bridging generation).

Those belonging to the bridging generation are exiles who, on the basis of having been born in Estonia could be considered part of the first generation, but who also, because of the fact that their views and attitudes were shaped in exile, could be regarded as connected with the second generation. For the purpose of comparing life stories interviews with those collected for the project "Perspectives of music in constructing the Estonian open identity", I have categorized the interview excerpts from Kirss' collection using my own system (i.e., the second generation includes the "bridging generation"). In fact, these alternative ways of distinguishing generations do not oppose one another, as both of the systems consider whether the interviewees' views and attitudes were shaped in the social-cultural environment of Estonia or the host country. I have used the same system of categorization when comparing the interviews from the collection Eesti ustest - sisse, välja. Quotes presented in this article 
originating from the abovementioned collection are differentiated from the other material with references.

Several problems occurring in diaspora community gave inspiration to Estonian exile writers. One can treat fiction as an indicator on its own: if a problem has been mentioned in a literary work, it could be deduced to have been a significant issue in the exile community. This article analyzes two novels: Elin Toona's Sipelgas sinise kausi all (The ant under the blue bowl) and Enn Nõu's Ma armastasin rootslast ehk Sollefteå suvi (I loved a Swede or summer in Sollefteå). Both novels are based on the exile authors' personal experience and reflect the relationships the refugees had with Estonia as well as the host country. In the context of the current study, both the authors and their characters represent the second generation of the old-diaspora group. The novels are similar by their main issue: the protagonists fall in love with non-Estonians and refuse to get married because the situation causes conflict between their romantic love and patriotic feelings.

\section{WHAT DOES IT MEAN - TO LOVE ESTONIA?}

Based on interviews, this section analyzes the essence of diaspora Estonians' patriotism and the ways they express their patriotic feelings. Approximately one third of the interviewees believed that a "proper" Estonian is someone who loves Estonia, thinks of Estonia often, and cares for the success and reputation of Estonia as a country, for example:

You are an Estonian if you love Estonia no matter how well you speak the language. Whenever you hear the word "Eesti", you prick up your ears and wonder what that person will say about it. If they speak poorly of Estonia, then, if they are acquaintances, you may keep your thoughts to yourself and curse them in your mind; however, if they are strangers, then you jump right in and defend Estonia fervently. (O-II-F, Canada)

In the course of the analysis, two interesting aspects were revealed. Firstly, only the representatives of the second and third generations of the old-diaspora group discussed their love for Estonia. This is intriguing because these generations were raised or born outside of Estonia. They have visited Estonia but have never lived in the country they love. Secondly, it emerged from the interviews that those who love Estonia often describe it as a fairy-tale land. These observations lead me to wonder how the love for a country such as Estonia, almost unknown to these generations, has emerged and developed. Based on a number of previous studies (e.g. Kiviloog 1978; Aun 1985), one can say that the first generation 
of the old-diaspora group made an attempt to raise the second generation to be Estonians - scouts' and girl guides' organizations, supplementary schools and church congregations played a significant role in achieving this goal. The interviews demonstrate that the positive positions parents held toward Estonia also had a strong influence:

We were raised speaking Estonian and remembering Estonia. (O-II-M, Australia/USA) (Kirss 2006: 566)

Father and mother were of the same mind and believed that we should be raised as Estonians and keep the English-speaking world at a certain distance. (O-II-M, Australia/USA) (ibid.: 571)

The interviews also revealed that the second and third generations feel a strong sense of belonging to the culture that constantly surrounds them in school or at the workplace in the host country. However, their contact with the heritage culture is realized in a special manner:

Being an Estonian was special, ceremonial, a Sunday honour, which became invisible when Monday evening came around. On Sundays we memorized Visnapuu ${ }^{1}$ and Liiv ${ }^{2}$, but on Mondays they were replaced by Shakespeare and Jean Racine. (Kirss 2008: 249)

"Raising an Estonian" in such cultural circumstances (living in two cultures simultaneously) could either be successful or unsuccessful. Constant pressure to feel patriotic could result in pushing youth away from their ethnic culture (Rakfeldt 1978: 29). In contrast, having the freedom to choose one's cultural belonging often worked in favor of the preservation of Estonian culture (Rand 1978: 84). It can be deduced from our interviews that the parents' "gentle directional urge" usually led the interviewees to develop a feeling of love for Estonia. The common term for this feeling is patriotism; however, not a single interviewee used this word to describe their feelings. It is interesting to note that when speaking of Estonia, the interviewees always spoke of love, whereas when speaking about their host country, they spoke of loyalty instead. A number of interviewees clearly defined and separated their feelings for each country:

Being an Estonian is two things: either it is a thing of the heart or a thing of the mind. Those people who lived their entire life in another country can only be Estonian at heart, while logically speaking they are loyal citizens of the host country. (O-II-F, Australia)

The third generation respondents often had very emotional responses, which indicated that Estonia is just a special place that should be loved unconditionally. "I love it! It is extremely important to me!" - this is a teenage boy's description 
of his relationship with Estonia as an Estonian-Canadian who does not speak Estonian (Ojamaa \& Valk 2008: 68).

\section{ESTONIA AS A FAIRY-TALE LAND}

The interviewees who feel love for Estonia often describe the country as a fairytale land. The following interview excerpts demonstrate that the emergence of such an image has been influenced by the stories of pre-war Estonia told by the older generation.

In childhood it did seem like a fairy-tale land. [---] When we spent time with our relatives, we heard their stories about how life in Estonia used to be [before going into exile in 1944]. We remember mainly good things. There of course were some difficulties, but it was still some kind of golden age. That is why it was like a fairy tale. (O-II-M, USA)

In her essay "Muinasjutust saab argielu" (A fairy tale becomes everyday life (Käpp et al. 2013: 211-215)), Marika Kristi Ets describes an excellent story of how love for Estonia can be initiated and how it can change over time. Her grandmother (first generation) can be regarded as the source of love. She told stories about the homeland, disposing her grandchild's early positive attitude toward the country which she only saw for the first time as a university student.

Moving to Estonia as an Estonian from abroad is like falling into a fairytale. You have heard about this place for your whole life, have sung about it, seen photos, so when you finally see the tiny sprat tin silhouette of Tallinn, you can hardly believe that you aren't in a dream. (O-III-F, USA) (Käpp et al. 2013: 211)

Estonians call the view of Tallinn from the sea, where the church spires and castle towers line the skyline, the "sprat tin silhouette". The silhouette became a visual symbol of Estonia already before the Second World War; it was used on the packaging of various products, including sprat tins. The notion "sprat tin silhouette" has had an important role in shaping the image of Estonia. Refugees took photos of the silhouette; later some artists in exile reimagined the silhouette in paintings and leatherwork, which can be found in the homes of diaspora Estonians all over the world. ${ }^{3}$ Thus, the towers of Tallinn have become an important symbol even for those who have never been to Estonia. The diaspora Estonians who on their first trip to Estonia arrived in Tallinn by sea, experienced at first hand how their prior visions met with reality. Many 
interviewees described this experience with positive emotions that they would never forget:

When I traveled to Tallinn for the first time in 1974, I was on the boat from Helsinki and I saw the towers of Tallinn in the distance and then it really was like - oh, there it is! It was such an experience to know that it really does exist! (O-II-M, USA)

In the following interview excerpt, the interviewee describes the arrival of the Toronto Estonian Supplementary School Choir in Tallinn for the 2004 Song Festival:

We flew to Helsinki by plane and went on from there on a ship. All the children did not fit onto the flight to Tallinn. But there was one other thing. We were able to see how Estonia... rose out of the sea, all those towers, which the children already knew about from their geography lessons. And they kept coming closer and closer... it was a big deal for the children. ${ }^{4}$ (O-II-F, Canada)

Symbolically, approaching Estonia by sea is like a journey backwards, compared to the flight of the older generation in 1944. Many refugees fled by sea, watching with heartache the coastline fade in the distance. Although the second and third generations have never fled the country, the interviews showed that they felt their arrival in Estonia as if they were returning.

When a direct encounter with the real Estonia occurs, it may draw a veil over the fairy-tale land image. Second generation interviewees, who had visited Estonia in the 1970s, felt some disappointment already during their first few days in the country.

[---] I had attended Toronto Estonian Supplementary School and was a scout and spoke Estonian at home, but Estonia really was a fairy-tale land. [---] My main impression of Estonia was that everything is very grey. (O-II-M, Canada) (Kirss 2006: 589)

The abovementioned O-II-M with an American background, who enthusiastically described the moment he saw the towers of Tallinn, continues his memories of his first encounter with Estonia:

Upon arriving in Estonia, the reality was harsh. The visit took place under the watchful eye of a $K G B^{5}$ officer, as is the practice in a totalitarian country, and it did not match the image of a fairy-tale land at all. (O-II-M, USA) 
Marika Kristi Ets (O-III-F) came to Estonia 30 years later than O-II-M. During that time, Estonia had been freed from the Soviet occupation and economy began to develop quickly. Estonia was no longer as grey and dirty and the KGB had finished its activity. Despite all this, her imagination of a fairy-tale land receded after some time:

Estonia does not seem to be a fairy-tale land to me anymore. It is now a real place with good and bad aspects. It is also my home. [---] I don't idealize Estonia anymore because I feel that I know this country more intimately now. [---] I know how cold the winters are and I know the stresses of everyday life. (O-III-F, USA) (Käpp et al. 2013: 213-214)

The last excerpt shows how the consequences of the collision of the two worlds imaginary and real Estonia - do not necessarily mean that the emotional value of the country is lost. One can still love the country despite its faults.

In the course of the analysis it became apparent that (1) the older generation's memories of life in Estonia supported the development of the younger generation's sense of patriotism; (2) some descendants of refugees, who did not have personal memories of Estonia, began to imagine Estonia as a fairy-tale land; (3) the younger generations felt the need to see the "fairy-tale land" with their own eyes and experience the immediacy of their ethno-cultural roots.

\section{FROM ILLUSIONS TO REALITY}

While examining the abovementioned conclusions in a wider context of diaspora discourse, one can say that they are not specific to Estonia. The older generation's creation of an embellished image of their country of origin, based on their memories, is a common characteristic in many diaspora communities. For example, in his study about Chinese American immigrants, Jean Amato (2015: 431) writes that "from the late 1950 s to the late 1970 s, internal political and social turmoil in China [---] and the larger international framework of the Cold War made almost all forms of contacts or visits to family members in mainland China untenable for Chinese Americans. [---] Thus, many Chinese Americans knew little about everyday life in the PRC, the state of their ancestral homes [---]. As a result, they could only look to tales of an ancestral home/homeland through the belated personal or familial legacy of memories [---]".

Another comparative example is connected with Prussian refugees. Similar to Estonians, the Prussians fled from the Soviet Army when the latter invaded Prussia in 1945. Most of the refugees settled in Germany and could not return to their former places of residence. What makes the Prussian case interesting 
is the fact that in the German Democratic Republic "it was dangerous for the Prussian expellees to express their attachment to their old homeland: they were afraid of their children's behavior. Children could easily say something that went against the grain of the official position, and this might have consequences for the whole family. So it happened frequently that the adults chose to lower their voice or that they completely avoided talking about the old home in the presence of their children" (Bierwerth 2015: 172).

The Prussian refugees' situation differed from that of the Estonian refugees, as Estonians lived in a free world and could openly remember their country of origin. Bierwerth's study shows that, despite the danger, Prussian refugees still shared their stories and memories of their homeland with their children. As a result, in the 1980s "return tourism" became popular; young people of Prussian origin began to visit their country of origin in masses. What they hoped to experience was slightly similar to Estonians' desire to visit the fairy-tale land: "The younger ones, those who know your places of origin mostly from their parents' reports, they say: Well, I want [---] to go and see what the sky looks like over there, or pick a flower, and so on" (ibid.: 179).

In some approaches, the myth of return holds an important place in the criteria of a diaspora community. According to William Safran (1991: 83-84), the shared hope of a return to the homeland creates a connection between the members of the diaspora community. Safran also finds that for a variety of reasons, in reality diaspora group members do not return to the homeland permanently "because there is no homeland to which to return; because, although a homeland may exist, it is not a welcoming place with which they can identify politically, ideologically, or socially; or because it would be too inconvenient and disruptive, if not traumatic, to leave the diaspora" (ibid.: 91). With reference to Avtar Brah's study, Kläger and Stierstorfer (2015: 3) demonstrate that in the diaspora context "home is a place of no return, even if it is possible to visit the place of origin. Nevertheless, members of the diaspora groups can be characterized by having a craving for home as a "mythic place".

With regard to the Estonian diaspora community, the intent to return to the homeland was widespread at the beginning of the life in exile, as the refugees believed their life abroad was only a short-term absence from the homeland. Cultural and political circles in exile made plans to continue their cultural and educational lives in Estonia after their expected return; the Culture Commission of the Estonian National Council in Sweden even published the programmatic document titled Eesti kultuurpoliitika sihtjooni: Juhtmõtteid eesti kultuuri taastamiseks vabal kodumaal (The goals of Estonian cultural politics: Thoughts on restoring Estonian culture in the free homeland (Tauli 1953)). However, the Cold War and the consequent political developments clearly indicated that return- 
ing was unrealistic. In addition, their ancestors' land was no longer considered home to the generation raised abroad. It was rather considered to be the origin of their roots, which - although important - one could survive without. Still, the wish of the older generation to return did not disappear without a trace. Over time, the strong desire to return was reduced to the myth of returning, which later became realized in the form of return tourism. According to Rakfeldt's (2015: 517) study based on material collected in 1991, "the most powerful predictor of Estonian identity was having visited Estonia [---]. Fifty-eight percent of participants had visited Estonia and, of these, $86 \%$ felt that the visit had definitely strengthened their Estonian identity. [---] The act of visiting Estonia had provided a powerful experience that evoked strong emotions".

Our interviews and essays revealed that the illusion of Estonia as a fairy-tale land did not coincide with reality. Several studies have shown that an idealization of the ancestral home is a common tendency of diaspora communities. They often "fabulate highly romantic fantasies of the 'old country' beginning with the Jews' 'promised land' flowing with milk and honey" (Cohen 1997: 185). Studies conducted in the 2000s about other diaspora communities have continually confirmed that the gap between fantasy and reality can be deep and cause disappointment. The above-mentioned study about Chinese Americans includes several examples of the reactions the Chinese had when they visited their country of origin, for instance, "Everything is poor! The country is poor! [---] The communists have ruined everything!" Amato concludes, "Nostalgic love can only survive in a long distance relationship" (Amato 2015: 437).

\section{TEACHING PATRIOTISM}

The new-diaspora group is not as sentimental toward Estonia as the old-diaspora group. In interviews and essays they discuss what is wrong in Estonia and what should be changed in order for anyone to want to return and live there. Based on our material, the new-diaspora group could be characterized as a group that is affected by the fate of the homeland, but that does not feel the desire to return. Thus, the new-diaspora group is missing one of the characteristics that Safran considered an important part of the diaspora experience. Loving Estonia and its fairytaleness seem not to be an important topic for the new-diaspora group. Only one interviewee mentioned the fairy-tale land, in the context of explaining the differences between the old-diaspora and new-diaspora groups:

Here, yes, it is like a fairy-tale land to them [the old-diaspora group], where everything is without fault, where the air smells like strawberries and fresh birch, the fields are beautiful and the sun is always shining; 
there is never any mud anywhere. Nevertheless, we all know that in reality it is not always like this. (N-I-F, Sweden)

New-diaspora group members have left voluntarily and for two main reasons: to study or to work. Many of them are economic immigrants, who hope to earn a better income and live in better conditions in another country. Estonians have been migrating for similar reasons since the nineteenth century, the main destination countries being Australia, South and North America, and Canada. Earlier studies show that when comparing political refugees who fled during the Second World War, voluntary (economic) migrants have a weaker sense of ethnic self-identification and an almost non-existent sense of patriotism (Pennar \& Parming \& Rebane 1975: vii-ix, 85; Salasoo 1986: 127). Other sources show that the attitudes the economic immigrants have toward Estonia have not always been homogenous. Some immigrants attempted to assimilate quickly, as this helped them be successful in the labor market. In contrast, others found that preserving ties with their heritage culture was important. This opinion is supported by the fact that economic immigrants established some of the first Estonian cultural societies in Canada and Australia at the beginning of the twentieth century (Kurlents \& Antik \& Olvet 1975: 34; Barrow 2012: 3). Many new-diaspora group members have also joined old Estonian organizations, which demonstrate that the connection to Estonian culture is still important to them.

In interviews, the new-diaspora group members do not talk about whether or how they love Estonia; yet, it is interesting that they do discuss how to pass the love for Estonia on to their children.

I would even say that it is better [to be] a second generation Estonian living abroad, who loves Estonia (and we believe, of course, that we are able to raise our children to love Estonia), than a native Estonian, who feels worse at home than anywhere else. (N-I-F, Finland) (Käpp et al. 2013: 251)

When we compare the first generations of the new-diaspora and old-diaspora groups, it becomes evident that they behave similarly - they begin to teach love for Estonia to their descendants who do not have immediate contact or have a weak connection with Estonia. In their future plans, their children will become the second generation of the new-diaspora group. They are preparing their children for life outside of Estonia, at the same time trying to preserve the awareness of their Estonian roots.

The interviews and essays show that in addition to retelling memories, speaking the Estonian language is very important. Language and love are inseparable according to all generations of the various waves of migration:

My contribution is also passing on the Estonian language to my children and together with it love for Estonia. (N-I-F, Germany) (Käpp et al. 2013: 252) 
Both the old-diaspora and new-diaspora interviewees believed music (song festivals and Estonian pop music) and visiting Estonia (especially participating in a song festival) to be important elements associated with loving Estonia. Only one interviewee discussed the role of literature. The older generation believes that young Estonians do not read books; thus, they are unable to influence their relationship with Estonia. Leelo Keevallik's study on Swedish-Estonian identity also confirms this opinion: "They wear national costumes to Independence Day ceremonies and subscribe to the Estonian-language newspaper, but reading Estonian literature is reported to be difficult by many of them" (Keevallik 2010: 181-182).

In the first decades of the exile period the circumstances were different from today. Literature in the language of origin belonged on the list of important identity markers, which the first generation attempted to use as a tool to cultivate patriotism in younger generations. In the document titled "Aims of Estonian cultural policy in exile", leading cultural-political figures emphasize:

The preservation of its youth for the Estonian nation demands more care than hitherto, not only from the refugee organizations and cultural and educational leaders, but also from all the refugees individually, more particularly from Estonian families. Special care must be taken that young people read Estonian literature [---]. (Estonian National Council 1956: 9)

There were a number of well-known writers among the refugees and in the 1940-50s, several publishing houses were established with the focus on actively dispersing Estonian literature outside of Estonia. Allegedly, by the end of 1945, 160,000 Estonian books had been published in Sweden (Horm 1946: 21). Our interviewees spoke with pride of how, in the context of their host country, the homes of Estonians drew attention with the large numbers of books they housed. As to be expected, most of the authors in exile wrote about life in Estonia. Arvo Mägi' (1968: 34) characterizes exile literature as "epoch literature", as it focuses on specific periods in Estonian history. Many authors have situated their novels in the pre-war period. Most often the activities take place at a safe cottage surrounded by beautiful nature, where days are filled with satisfying work. Such books had the potential of supporting the myth of the fairy-tale land. A significantly smaller number of novels touch on the exile period (Kangur \& Muru \& Tonts 1991: 7). The activities in these novels often take place in a big city, where characters of Estonian origin encounter other ethnic groups forcing them to communicate in a foreign language. Several problems arise in connection to ethnic identity and patriotism, as well as the lack of a sense of security and an unfulfilled need for an intimate closeness with other people. 


\section{PATRIOTIC FEELINGS VS ROMANTIC FEELINGS}

According to Tõnu Parming's (1978: 4) opinion, the older generation expected exile literature to generate a sense of ethnic belonging and patriotism among Estonians. He argues that the novels and poetry were lacking in relationships reflecting romantic or intimate love and rather were dominated by love for Estonia. In his essay "Eros ja Esto" (Eros and Estonianness), Parming (1979: 51) writes that the novels by exile authors directed young Estonians to communicate with each other as compatriots; thus, pushing gender roles in the background, which further contributed to the formation of mixed marriages. Parming concludes that exile literature produced Estonianism, but simultaneously inhibited the "production of new Estonians". Our interviews consist of examples that both confirm and contradict Parming's viewpoints; for example, an interviewee describes his Estonian friends in Sydney:

There were relationships and crushes, but if you were to look at who found themselves a partner, then many had outside marriages. Relationships within the group developed into mutual friendships. (O-II-M, Australia/ USA) (Kirss 2006: 577)

An O-II-M found himself an American girlfriend while living in the USA, but after some time he had to leave her behind:

It was my first serious relationship with a non-Estonian. [---] We went to Australia too. It was not a good experience. I remember we visited my grandfather and speaking English in his house was a grim event. Soon after, our relationship ended. (Kirss 2006: 581)

An O-II-M married an Estonian. The following example comes from his Swedish generation-mate, although this story ended with a mixed marriage:

There was a boy. He did not live in Stockholm, but when there was an Estonian party or something, he stayed the night at our house, in my room. But no, I did not ever think that... He was like a brother to me! (O-II-F, Sweden)

An O-II-F came from an Estonian-minded home; she married a compatriot whom she met away from home, in Canada. The couple made the effort to tie their marriage to "Estonian life", but the husband was not interested in Estonian social life, and the marriage resulted in divorce. The interviewee returned to Sweden and married a Swede. She is still married and also an active member in the Estonian-Swedish diaspora community. This case demonstrates that love for a Swede does not necessarily prevent love for Estonia or vice versa. 
Inspired by Parming's perspectives and based on the interviews, we could look for the impact literature had on real life. Based on the interviews, we can conclude that the youth did not use literature as an example when choosing a partner in marriage, whether they married an Estonian or someone else. However, one can agree with Parming that the attempt to generate patriotism is clearly perceptible in fiction written by authors of the old-diaspora first generation. The role of literature and writers as the supporters and promoters of ethnic identity is considered important also in many other diaspora communities. According to Anteby-Yemini \& Berthomière (2005: 265), "most of the leaders of a diaspora community were (and still tend to be) intellectuals, writers, very active in the public sphere".

Over time, Estonian exile literature became more critical of the uncompromising demands for Estonianism. In the mid-1960s, the second generation of the old-diaspora entered literature. The conflict between patriotism and choosing the right partner in marriage became one of the more pointed problems in their work.

Two excellent examples of this are Elin Toona's ${ }^{7}$ novel Sipelgas sinise kausi all (The ant under the blue bowl, 1974) and Enn Nõu's ${ }^{8}$ novel Ma armastasin rootslast ehk Sollefteå suvi (I loved a Swede or summer in Sollefteå, 2013). The novels are set in the 1950s-60s. Both of the protagonists - Ants Karusoja in the first novel and Eerik Neier in the second one - are the authors' peers. They live their life in exile, in the same countries as the authors (England and Sweden). Both protagonists were raised in families that respected Estonian traditions. They keep their distance from other ethnic groups in order to preserve their Estonianness, and only minimally participate in the culture of their host country. Both protagonists wish to marry, but are unable to find a suitable partner from among their compatriots. Ants Karusoja begins to develop an intimate relationship with an Englishwoman Pauline Lovejoy, and Eerik Neier with a Swede Ingalill Stormare. In both cases, the protagonists end the relationships because of their strong patriotic feelings.

In the novel Ma armastasin rootslast ehk Solleftea suvi (I loved a Swede or summer in Sollefteå) the plot begins in the summer of 1955, when the protagonist Eerik is serving in the Swedish army. In this situation it is important to notice a hint at the loyalty the Estonian refugees felt towards the country that had granted them asylum. Our interviews reveal that loyalty is also a strong characteristic of the second generation. However, loyalty is not Nõu's main theme; he focuses on the love story between an Estonian refugee and the daughter of a Swedish officer. Nõu clearly directs attention to the problems faced by those of marriageable age in the second generation, to which they had to find answers in reality: What kind of love is the "right" love? How does 
Estonianness relate to marriage or would mixed marriage be acceptable in the exile community?

In reality, members of the older generation believed that an Estonian man should find an Estonian girl to marry; this is also postulated in the novel (see Nõu 2013: 99). The author's tone is neutral; thus, it is difficult to determine whether he himself shares the stance of the older generation or not. One can only state that the author ends the protagonist's love story in the early stages, with his surrender to the nationalist principle:

Inevitably, the conflict of Estonian vs. Swedish had to arise sooner or later; it was engrained from the beginning and is a high price to pay for a fanatic nationalist. [---] In the interests of the Holy Estonian people, one is forced to act in this way, to place love on the altar as a sacrifice to the homeland. (Nõu 2013: 210)

The protagonist of Toona's novel, Ants Karusoja, comes to the conclusion - after weighing the pros and cons - that marrying an English woman would mean removing the Estonian language, food, and other traditions from his everyday life. A mixed marriage would be "crossing over from one national culture to another" (Toona 1974: 228); it would be a betrayal of Estonianness. The protagonist quickly leaves the meeting place where his English love was soon to arrive, rushing home to where a rich Estonian Christmas lunch awaits him.

Both authors have placed their protagonists in doubtful positions. Their decisions to end their relationships were not easy and they were not entirely convinced that they had made the right choice. One important question to raise doubt is what love means. Toona demonstrates in multiple episodes that linguistic miscommunication and many cultural misunderstandings can occur between the Estonians and the English, also in matters of love. Ants Karusoja reflects: "In Estonian the word 'love' has only one absolute meaning. In English, however, it can have many." (Toona 1974: 217)

But what does it mean exactly? In her novel, Toona does not unpack the ethno-cultural aspects of love. In this sense, Nõu's novel is more informative; he uses the term "Estonian-like love" (2013: 103), which means that romantic love must also include a nationalist component (i.e. patriotism). Eerik Neier does not believe it is possible to love a Swede and Estonia simultaneously.

The critic Meelas Karutald (2014: 28) writes that in Eerik's case the reader today could see the consequences of poor integration politics. I believe that both Nõu's and Toona's novels reflect the natural process of integration in an excellent manner, including all the positive and negative developments. The novels exemplify how the refugees wished for the dominant group to accept them, but also how they did not want to abandon any of their nationalist ideas or cultural heritage. 
It is interesting that both authors have shown that, in comparison with the refugees, the level of integration readiness is much higher among the dominant group. For example, Pauline would have happily married Ants despite his ethnic affiliation, different food, and other traditions. Ingalill was even ready to learn Estonian to be acceptable as a wife for Eerik. However, neither of the female characters could have fully shared Estonian heritage, love and loyalty for the country with their husbands, which at the beginning of exile period was the deciding factor in the eyes of the older generation.

\section{CONCLUSION}

The interview-based studies on diaspora often include examples in which the interviewees express their nostalgic and patriotic feelings toward their country of origin. The Estonian material reveals that the representatives of various groups (refugees and voluntary immigrants or new and old diaspora) describe their feelings differently. The new-diaspora group which began to develop in the early 1990s consists mainly of economic immigrants. In comparison to refugees they are more critical of the living conditions in Estonia, though not indifferent to its future. The members of the old-diaspora group mostly speak about their interest in Estonia's development, their pride, and sometimes their heartache for Estonia. A much smaller part of interviewees summarized their attitudes and feelings toward Estonia with the word "love". However, when analyzing the interviews, discussions about love for Estonia came to my attention; the topic frequently arose in the interviews with old-diaspora second and third generation members who had been raised and/or born outside of Estonia.

The second and third generation diaspora-Estonians are bicultural; thus, they share their patriotism between two countries. It is interesting that patriotism towards different countries can spring for different reasons. For example, immigrants who feel love or loyalty for the United States of America associate the country with freedom and justice, which are also the country's most important core values in official discourses. In addition, our interviews revealed that loyalty for a host country is inseparable from the gratitude the refugees feel for receiving help after the Second World War. Diaspora-Estonians love Estonia for a very different reason: it is the country of their ancestors and the source of their cultural heritage, in addition to having the connotation of a fairy-tale land.

The second and third generation of the old-diaspora group have been raised abroad; thus, they do not have any personal experience of Estonia. Estonian supplementary school and youth organizations have purposely shaped their attitudes. Studies on diaspora communities of various ethnic backgrounds have 
shown that, when teaching love for the ancestral homeland, the universal tool is retelling memories to the younger generations. This tool also fits well in the context of the Estonian Western diaspora. For Estonians, important tools for raising patriotism are also speaking Estonian (language of origin is regarded one of the main identity markers for Estonians) and a connection to the Estonian music culture (Estonians call themselves a "singing nation").

With regard to romantic love, the analyzed material reflects changes in the attitudes of diaspora Estonians. In the first decades of the exile period, the discussions in the diaspora community surrounding the "right love" or "Estonian kind of love" and the attitude toward mixed marriages was negative, as it was seen as a threat to the preservation of Estonian identity.

The members of the third generation are more open about their decisions: they do not speak about loving Estonia or Estonians as an obligation. The interviews reveal that the second generation consciously tried to avoid putting pressure on their children to love Estonia in a certain way, as they had experienced the pressure in their own childhood. Many members of the newdiaspora group are married to non-Estonians, in which case mixed marriage is more of an everyday reality than a complicated problem. The third generation of the old-diaspora group and the first generation of the new-diaspora group are similar in their views on multiculturalism. They believe that no matter what kind of connection they may have with other cultures, it will threaten neither their being Estonian nor their positive feelings toward Estonia.

\section{ACKNOWLEDGEMENTS}

Research for this article was supported by the Centre of Excellence in Estonian Studies (CEES, European Regional Development Fund) and is related to research project IUT 22-2 (Estonian Research Council). The author wishes to thank the anonymous reviewers for the valuable comments. 


\section{NOTES}

1 Henrik Visnapuu, Estonian poet (born in Estonia in 1890, died in the USA in 1951).

2 Juhan Liiv, Estonian poet (1864-1913) (born and died in Estonia).

${ }^{3}$ For a more detailed overview of symbols and other designed elements that represent ethnic identity in the diaspora Estonians' homes see Kõiva 2007: 57-61.

4 To read more about the emotions Canadian-Estonian teenagers experienced while traveling see Ojamaa 2011: 292-299.

5 The Committee for State Security was active in Estonia from 1954-1991.

${ }^{6}$ Arvo Mägi (born in Estonia in 1913, died in Sweden in 2004), Estonian author and journalist.

7 Elin Toona was born in Estonia in 1937. She fled to Germany in 1944, continued to England in 1947, where she studied at a theatre school. She currently lives in the USA. She became known as a writer in 1964.

8 Enn Nõu was born in Estonia in 1933. He fled to Sweden in 1944, where he graduated from the medical program at Uppsala University. He became known as a writer in 1968 .

\section{REFERENCES}

Amato, Jean 2015. It All Depends on What You Mean by Home: Metaphors of Return in Chinese American Travel Memoirs from the 1980s to 2010s. In: Florian Kläger \& Klaus Stierstorfer (eds.) Diasporic Constructions of Home and Belonging. Berlin \& Boston: De Gruyter, pp. 427-446.

Anteby-Yemini, Lisa \& Berthomière, William 2005. Diaspora: A Look Back on a Concept. Bulletin du Centre de recherche français à Jérusalem, Vol. 16, pp. 262-270. Available at http://journals.openedition.org/bcrfj/257, last accessed on 15 July 2019.

Aun, Karl 1985. The Political Refugees: A History of the Estonians in Canada. Toronto: McClelland and Stewart Ltd.

Barrow, Maie 2012. Estonians in Australia. Adelaide: Council of Estonian Societies in Australia.

Bierwerth, Gesa 2015. The Process of Integration among German Expellees in the GDR. In: Florian Kläger \& Klaus Stierstorfer (eds.) Diasporic Constructions of Home and Belonging. Berlin \& Boston: De Gruyter, pp. 163-182.

Cohen, Robin 1997. Global Diasporas: An Introduction. Seattle: University of Washington Press.

Estonian National Council 1956 = Estonian Culture in Exile: 10 Years of Estonian Cultural Activities in Sweden. Aims of Estonian Cultural Policy in Exile. Outlines of Estonian Cultural Policy. Estonian National Council Publication No. 7. Stockholm: Estonian National Council. 
Horm, Arvo 1946. Meie ja maailm: meie kultuurpropaganda - unustatud vaeslaps. [We and the World: Our Cultural Propaganda - a Forgotten Orphan.] Kodukolle, No. 7/8, pp. 21-23.

Kangur, Piret \& Muru, Karl \& Tonts, Ülo 1991. Väliseesti kirjandus. [Estonian Exile Literature.] Tallinn: Eesti Raamat.

Käpp, Triin \& Parder, Mari-Liisa \& Pisuke-Roos, Triin \& Sutrop, Margit \& Volberg, Mats (comps. \& eds.) 2013. Eesti ustest - sisse, välja: kõned, artiklid, esseed. [In and Out of Estonia's Doors: Speeches, Articles, and Essays.] Tartu: Eesti Keele Sihtasutus.

Karutald, Meelas 2014. Kaks sinimustvalget romaani. [Two Blue-Black-White Novels.] Sirp, 24 January, p. 28. Available at http://www.sirp.ee/s1-artiklid/c7-kirjandus/ kaks-sinimustvalget-romaani/, last accessed on 28 March 2018.

Keevallik, Leelo 2010. Everyday Construction of Identity in the Estonian Refugee Community in Sweden. Journal of Baltic Studies, Vol. 41, No. 2, pp. 177-200. http:// dx.doi.org/10.1080/01629771003731705.

Kirss, Tiina (comp.) 2006. Rändlindude pesad: Eestlaste elulood võõrsil. [The Nests of Migratory Birds: Estonians' Life Stories Abroad.] Tartu: Eesti Kirjandusmuuseum \& Toronto Ülikooli Eesti õppetool.

Kirss, Tiina 2008. Väärtustest ja eestluse tulevikust. [About Values and Future of Estonianness.] Akadeemia, Vol. 2 (227), pp. 236-256. Available at http://www. akad.ee/wp/2008/02/10/akadeemia-nr-2-2008/, last accessed on 29 March 2018.

Kiviloog, Helena 1978. Missuguseks eestlaseks? [To What Kind of Estonian?] In: Aja Kiri, No. 4, pp. 37-44.

Kläger, Florian \& Stierstorfer, Klaus 2015. Introduction. In: Florian Kläger \& Klaus Stierstorfer (eds.) Diasporic Constructions of Home and Belonging. Berlin \& Boston: De Gruyter, pp. 1-7.

Kõiva, Mare 2007. Austraaliaeestlased: migratsioon, kohesioon ja ruumimudelid. [Estonians in Australia: Migration, Cohesion, and Spatial Models.] In: M. Kõiva (comp.) Paar sammukest XXIII: Eesti Kirjandusmuuseumi aastaraamat. Tartu: EKM Teaduskirjastus, pp. 33-70. Available at http://www.folklore.ee/rl/pubte/ ee/araamat/2007/2marekoiva.pdf, last accessed on 29 March 2018.

Kurlents, Alfred \& Antik, Richard \& Olvet, Jaan 1975. Eestlased Kanadas: Ajalooline koguteos. [Estonians in Canada: Historical Collection.] Vol. 1. Toronto: Kanada Eestlaste Ajaloo Komisjon.

Mannheim, Karl 1953 [1952]. Essays on Sociology and Social Psychology. London: Routledge \& Kegan Paul. Available at https://archive.org/stream/ essaysonsociolog00mann\#page/n7/mode/2up, last accessed on 29 March 2018.

Mägi, Arvo 1968. Eesti pagulasproosa Rootsis ajapeeglina. [Refugee Prose by Estonians in Sweden as a Mirror of Time.] In: M. Üürike (ed.) Eesti Päevad Stokholmis 4.15. mail 1968. Eesti Päevade üldkava. Artikleid eestlaste kultuurilisest tegevusest. Stockholm: Eesti Kultuuri Koondis Stockholmis, pp. 34-47.

Nõu, Enn 2013. Ma armastasin rootslast ehk Sollefteå suvi. [I Loved a Swede or Summer in Sollefteå.] Tallinn: Tänapäev.

Ojamaa, Triinu 2011. 60 aastat eesti koorilaulu multikultuurses Torontos. [60 Years of Estonian Choral Singing in Multicultural Toronto.] Tartu: Eesti Kirjandusmuuseumi Teaduskirjastus. 
Ojamaa, Triinu \& Karu-Kletter, Kristel 2014. Diasporaa-eestlaste enesekuvand muutuvas maailmas. [The Self-Image of Diaspora Estonians in the Changing World.] Methis: Studia humaniora Estonica, Vol. 10, No. 13, pp. 173-169. DOI: 10.7592/ methis.v10i13.1309. Available at https://ojs.utlib.ee/index.php/methis/article/ view/1309/1258, last accessed on 15 July 2019.

Ojamaa, Triinu \& Valk, Aune 2008. Pilootuurimus kanadaeestlaste etnilise identiteedi ja muusika seostest. [Relationship Between Estonian-Canadians' Ethnic Identity and Music: A Pilot Study.] In: K. Labi (ed.) Paar sammukest XXIV: Eesti Kirjandusmuuseumi aastaraamat 2007. Tartu: Eesti Kirjandusmuuseumi Teaduskirjastus, pp. 59-85.

Parming, Tõnu 1978. Eestlased, intiimsus, armastus, abielu ja lahutused. [Estonians, Intimacy, Love, Marriage, and Divorces.] Välis-Eesti, 24 November, p. 4.

Parming, Tõnu 1979. Eros ja Esto. [Eros and Estonianness.] In: E. Klaar \& J. Maandi \& A. Reinson \& J. Seim (eds.) Metroo teine raamat. Stockholm: Metroo-trükk, pp. 32-53.

Pennar, Jaan \& Parming, Tõnu \& Rebane, P. Peter 1975. The Estonians in America 1627-1975: A Chronology \& Fact Book. Ethnic Chronology Series, No. 17. Dobbs Ferry, New York: Oceana Publications.

Qianqian Li 2015. Becoming an American: Rethinking the United States Naturalization Policy. In: Florian Kläger \& Klaus Stierstorfer (eds.) Diasporic Constructions of Home and Belonging. Berlin \& Boston: De Gruyter, pp. 315-330.

Rand, Walter 1978. Globaalne eestlus. [Global Estonianness.] Mana, Vol. 45, pp. 77-85. Available at https://www.digar.ee/arhiiv/et/perioodika/63444, last accessed on 14 May 2018.

Rakfeldt, Jaak 1978. Äärel olemine. [Being at the Border.] Aja Kiri, No. 4, pp. 27-30. Available at https://www.digar.ee/arhiiv/et/perioodika/36723, last accessed on 14 May 2018.

Rakfeldt, Jaak 2015. Home Environments, Memories, and Life Stories: Preservation of Estonian National Identity. Journal of Baltic Studies, Vol. 46, No. 4, pp. 511-542. https://doi.org/10.1080/01629778.2015.1075137.

Reeskens, Tim \& Wright, Matthew 2014. Host-Country Patriotism among European Immigrants: A Comparative Study of Its Individual and Societal Roots. Ethnic and Racial Studies, Vol. 37, No. 14, pp. 2493-2511. http://dx.doi.org/10.1080/01 419870.2013 .851397$.

Safran, William 1991. Diasporas in Modern Societies: Myth of Homeland and Return. Diaspora: A Journal of Transnational Studies, Vol. 1, No. 1, pp. 83-99. http:// dx.doi.org/10.1353/dsp.1991.0004.

Salasoo, Inno 1986. The Estonians in Australia. In: M.Cigler (ed.) The Baltic Peoples in Australia: Lithuanians, Latvians, Estonians. Australian Ethnic Heritage Series. Melbourne: AE Press, pp. 107-164.

Tauli, Valter (comp.) 1953. Eesti kultuurpoliitika sihtjooni. Juhtmõtteid eesti kultuuri taastamiseks vabal kodumaal: Esialgne kavand. [Directions of the Estonian Cultural Policy. Some Ideas about the Restoration of Estonian Culture in Free Homeland: Preliminary Plan.] Stockholm: Eesti Rahvusnõukogu Kultuurikomisjon.

Toona, Elin 1974. Sipelgas sinise kausi all. [The Ant under the Blue Bowl.] Lund: Eesti Kirjanike Kooperatiiv. 
Triinu Ojamaa

Valk, Aune \& Karu-Kletter, Kristel \& Drozdova, Marianna 2011. Estonian Open Identity: Reality and Ideals. Trames, Vol. 15, No. 1, pp. 33-59. Available at http://www. kirj.ee/18474/, last accessed on 14 May 2018. 


\title{
CONTINUITY AND REVITALISATION IN SACRIFICIAL RITUALS BY THE EASTERN UDMURT
}

\section{PART I. THE COLLECTIVE SACRIFICIAL RITUALS BY THE BASHKORTOSTAN UDMURT: ROOTED IN TRADITION}

\author{
Eva Toulouze \\ Institut National des Langues et Civilisations Orientales, Paris, France \\ Department of Ethnology, University of Tartu, Estonia \\ e-mail:evatoulouze@gmail.com

\section{Ranus Sadikov} \\ Department of Ethnography, Kuzeev Institute of Ethnological Research \\ Ufa Science Centre of the Russian Academy of Sciences, Russia \\ e-mail:kissapi@mail.ru
}

\section{Laur Vallikivi}

Department of Ethnology, University of Tartu, Estonia

e-mail: laur.vallikivi@ut.ee

\section{Liivo Niglas}

Department of Ethnology, University of Tartu, Estonia

e-mail: liivo.niglas@ut.ee

\section{Nikolai Anisimov}

Department of Folkloristics, Estonian Literary Museum, Estonia e-mail:nikolai.anisimov@folklore.ee

\begin{abstract}
This article focuses on a marginal Udmurt group living in Bashkortostan, which has retained, in a Muslim environment, its original Udmurt religious practice. In some places, in spite of decades of anti-religious Soviet policy, the Udmurt were able to pursue their traditional rituals, thus warranting full continuity of their practice. In other places, the tradition was discontinued for some longer or briefer periods. But everywhere there has been a revival at the end of the twentieth and the beginning of the twenty-first centuries. The aim of this article, which is based on the authors' fieldwork in one district, is to examine
\end{abstract}


these processes and analyse them. In the first instalment, we introduce the geographic, cultural and mostly historic context explaining the resilience of the Udmurt religious practice. We show how much was retained and how in some villages full continuity of religious practice was achieved.

Keywords: agrarian religion, anti-religious policy, diaspora, religious practice, sacrificial ceremonies, sacrificial priests, Udmurt, village community

After the fall of the Soviet Union, the spiritual world of the formerly atheist state faced a spiritual turmoil. Old and new religions occupied the public space and sought for support. Besides all the institutional churches, Russia's "ethnic religions" also started to find a new voice. These religions, called in the Russian tradition "pagan" (Rus. язьчество), had also been persecuted during the Soviet times, and in some places had survived more or less in secrecy. They started to express themselves anew and to look for a place in the new context. The aim of this article is to analyse the ongoing processes. In the ethnic group we are working on there is clearly a religious revival at the turn of the twenty-first century, which is peculiar and complex. We attempt to unravel its proceedings

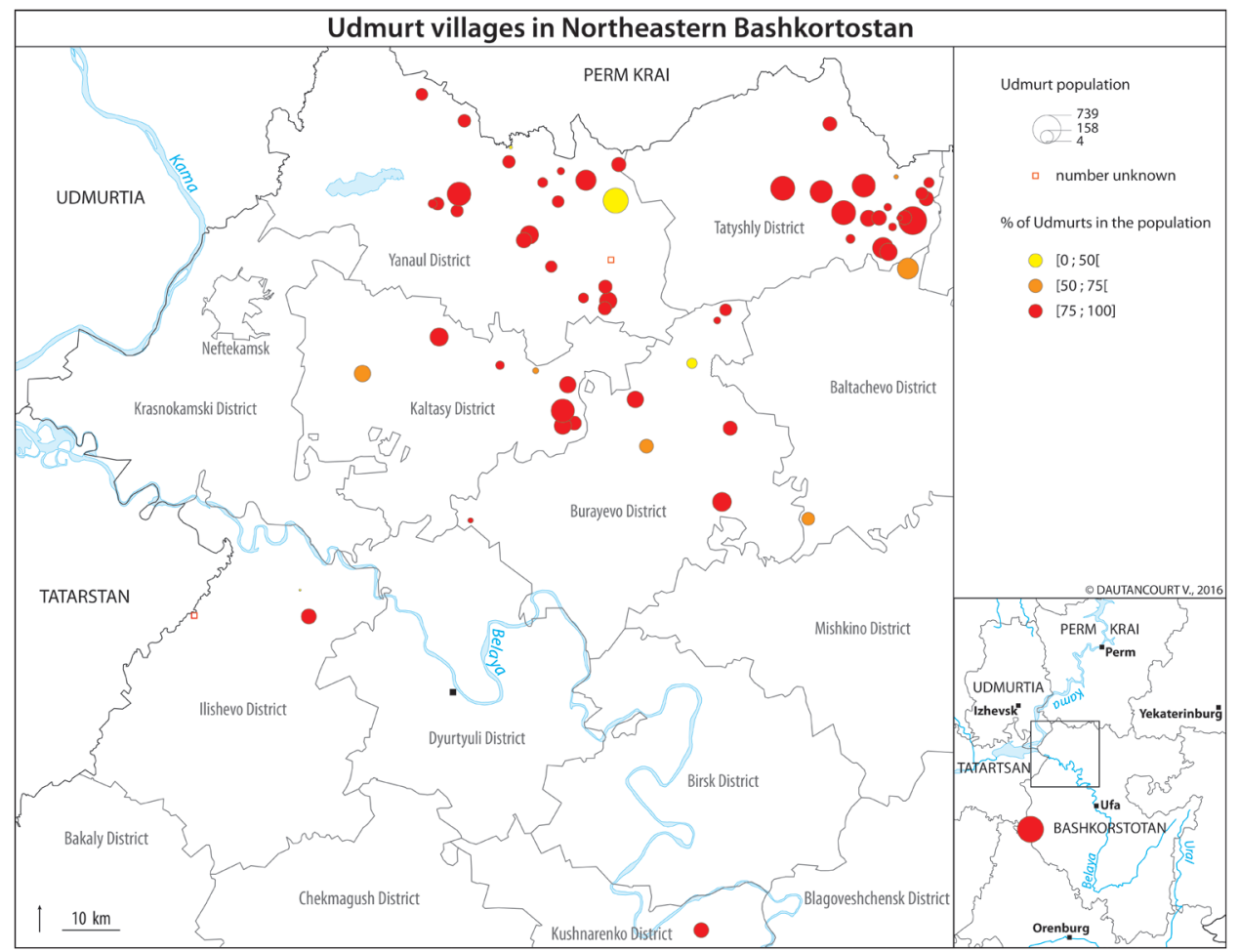


and to interpret its peculiarities in a wider context. In the first instalment, we present the region researched and the situation of religious practice in the villages at the beginning of the revitalisation process.

The Udmurt we study, who live in the north-western districts of the Republic of Bashkortostan and in the south of Perm district and are called Eastern $\mathrm{Udmurt}^{1}$, have retained their ancestral religion more than any others.

Throughout history, they have faced permanent attempts of evangelisation and Islamisation, which started in the sixteenth century and continued until the nineteenth century, but have still kept their religious practices, even opposing the Orthodox Udmurt, and calling themselves "true" Udmurt (Udm. чььн удлортәёс). Nowadays, they explain their migration to the Bashkir lands with their desire to preserve their original religion (Yagafova et al. 2010: 104-108). ${ }^{2}$

At the beginning of the twentieth century, most aspects of life among the Eastern Udmurt were tied to rituals. The social basis of the Udmurt ethnic religion was the rural community, in which the respect for norms and rituals was the condition for the prosperity of agricultural work and overall welfare. The Soviet years brought significant changes also to this field: collectivisation disrupted the rural community and the state implemented its antireligious policy, which limited the possibilities of practising one's religion actively and openly. The collective ritual activity as a basic element of social practice was diminished, although the private sphere, within the patrilineal clan, resisted more firmly (Sadikov 2011: 21, 42-43). The upholding of the collective sacrificial rites depended very much on the personal initiative of the sacrificial priests, the vös'as' (Udm. вӧсясь).

In the $1990 \mathrm{~s}$, with the transformation of the socio-political situation in the country, a revival started in the religious traditions of the Eastern Udmurt. Different factors influenced this process of revival, as, for example, the original level of preservation through transmission by the elders as well as the activity of the sacrificial priests, of the local authorities, and of the community itself. The heterogeneity of the process explains the complexity of the subject: there is a whole range of different situations, from total continuity to real revival. We shall illustrate our reflection with the case of the collective sacrificial ceremonies $^{3}$ (Toulouze \& Niglas 2014) of the Eastern Udmurt living in the Tatyshly district of Bashkortostan, for the different situations are all represented in the sample; moreover, in this region, the collective ceremonies form an entire cycle, actually even two, in spring and in late autumn; and it is also the place where the authors have mainly carried out their fieldwork. ${ }^{4}$ We will also reflect on the consequences of the ongoing revival and discuss, in our conclusion, whether it leads to major institutionalisation or centralisation, like what happened with the Mari ethnic religion in Mari El. 
For this study, we have primarily drawn on our fieldwork. Indeed, we have almost no written materials to work on as no researcher has visited this region at the time when Udmurt religion in the Bashkir area was not yet a target of major institutional interference, i.e., until the second decade of the twentieth

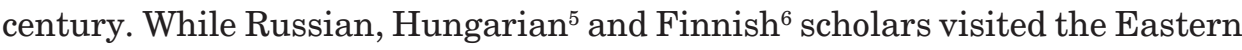
Udmurt from the end of the nineteenth century, none happened to gather materials in this particular area. In order to document the more distant past, we rely on oral information given by elderly people, born mostly between 1910 and the beginning of the 1930s, who had personally witnessed the ritual practices of earlier periods or heard about it from their parents. However, we also rely on the work of two Udmurt scholars. Eastern Udmurt ethnographer Tatiana Minniyakhmetova published the results of her fieldwork, carried out at a time when there were more elderly informants who remembered the pre-Soviet period and thus she provides precious data about the past (Minniyakhmetova 2000). Ranus Sadikov, one of the co-authors of this article, has also been doing fieldwork in this region since 1995, focussing on long-term changes and thus providing a valuable insight into diachronic processes. Researchers from Udmurtia have occasionally been exploring different aspects of the Udmurt culture in the eastern groups. Some of them have carried out fieldwork, such as dialectologist Valentin (Valey) Kel'makov, who collected samples in the Tatyshly district (Kel'makov 1974), among which interesting information about religion may be found; ethnologist Vladimir Vladykin, who wrote a major overview of the Udmurt religion (1994), as well as linguist Mikhail Atamanov and ethnographer Lyudmila Khristolyubova, who worked in close cooperation with Tatiana Minniyakhmetova. Still, their research only occasionally focuses on the Eastern Udmurt per se and its primary aim is to reflect on the Udmurt culture or religion as a whole. Our goal is somewhat different ${ }^{7}$ : we do not intend with this article to state general characteristics of the Udmurt, but to analyse the present situation of religious practice by the Tatyshly Udmurt, what is happening today and what represents a change in relation to the previous situation.

In this paper we mainly explore the ongoing processes as we draw on our observations as a team since 2013 . We have systematically attended sacrificial ceremonies both in the late spring and the late autumn cycles, documenting them thoroughly, and we have been in the field every year, sometimes twice or more a year. Our team is multi-ethnic, multilingual, and interdisciplinary: part of the team comes from the Institute for Ethnological Studies at the Ufa Federal Centre of the Russian Academy of Sciences (Ranus Sadikov), the others are affiliated to Estonian institutions, the University of Tartu (Eva Toulouze, Liivo Niglas, Laur Vallikivi), and the Estonian Literary Museum (Nikolai Anisimov); among the authors, there are two Udmurts - one from the neighbour- 
ing district of Buraevo in Bashkortostan and one from Southern Udmurtia, two Estonians, and a French researcher; there are three anthropologists, one folklorist (Anisimov) and one ethnographer (Sadikov, as defined in the Russian research tradition). When our Udmurt colleagues participate, most of the communication during fieldwork ${ }^{8}$ takes place in Udmurt and is carried out by them; the non-Russian scholars have relied on Russian (though especially older people are not fully fluent in it). Our fieldwork has been based on participant observation (living in the villages and participating in the life of our hosts, meeting their kin and neighbours, but also attending ceremonies, participating in them and visiting sacred places), as well as interviews (with the organisers of the ceremonies, the sacrificial priests as well as ordinary members of the communities). We have also widely used audio-visual methods, such as video recording, audio recording, and photography. Visual methods allow us, on the one hand, to document, and to fix important ethnographic data, recording directly ritual activities and the oral texts that accompany them. Moreover, the camera also records conversations and remarks from the participants; they may comment on or discuss the event, which provides valuable insights for research, but they may also exchange casual remarks about other everyday life issues that are relevant for them and for village life. The camera also allows suggesting dimensions of the ritual experience, which is more difficult to transmit through other media - the sensory aspect (Niglas 2016). On another level, we can edit the recorded video material, and prepare audio-visual descriptions of each ceremony, which we leave to the religious specialists of different villages and to the local Udmurt cultural centre, providing the local people with means to pass on, if they are willing to, their own tradition.

Firstly, we will shortly discuss the notions of continuity and revival among the Bashkortostan Udmurt, and clarify this somewhat confusing issue from the perspective of different scholarly traditions.

\section{CONTINUITY AND REVIVAL: A PROBLEMATIC ISSUE AMONG THE BASHKORTOSTAN UDMURT}

As mentioned previously, there has been some field research done on the Eastern Udmurt earlier, which gives us valuable insights into the situation at the beginning of the twentieth century: particularly precious is Uno Holmberg's [Harva] Permalaisten uskonto (The Religion of the Permians) in Finnish (19141915), which is a synthesis of the available data just before the borders were closed and fieldwork became impossible for foreigners. Except for Hungarian scholars Gábor Bereczki and László Vikár, who nevertheless concentrated on 
singing culture, no fieldwork was carried out in later years until the fall of the Soviet Union. Even Russian scholars, who had access, did almost no research on religion in the region. After 1990, fieldwork has become possible, and some researchers have focused on Udmurt religion - Finnish scholar Anna Leena Siikala and Estonian scholar Aado Lintrop (Lintrop 2003; Siikala \& Ulyashev 2011). ${ }^{9}$ Most of these researchers have been working in Udmurtia, but not in the diaspora, i.e., not in the regions where Udmurt religion has been and still is most vigorous. Aado Lintrop has been working in Varkled-Bodya (near the border of Udmurtia in Tatarstan), an isolated village that has preserved a rich non-Christian religious tradition. But here we deal with a whole region, in which Christianity is practically absent, and this creates particular conditions, quite different from the other cases. Therefore, their material and conclusions are either quite or slightly different from ours, so we will discuss them in comparison to them.

Russian ethnography takes, as a starting point, the period in which "traditional" (e.g. agrarian) culture is supposed to have reached its peak in the early twentieth century, just before the decline that took place after the Bolshevik Revolution. One way for us would be to compare the contemporary phenomena to what we know of this earlier period previous to the external and disrupting interferences. However, this is a tricky approach for two reasons: firstly, as mentioned above, we have no reliable data about the pre-Soviet period in this region; secondly, there have been some significant changes in-between, which deserve to be taken into account. Another way could be to start from a later point, the period just before the awakening of the $1990 \mathrm{~s}$, and to examine what had been retained from the earlier tradition (as much as we know about it), as well as analyse what the newest initiatives have brought forth. In our view, the second approach is more promising, because, on the one hand, it allows to follow what has happened in roughly one century, and thus to take into account the different local ways to tackle the pressures from the state as well as the different levels of continuity the local communities have been able to retain.

The issue of continuity and revival is particularly interesting if we take into account, as a comparison point, the situation in the south of Udmurtia, where coercive and thorough evangelisation took place, which made part of the population to migrate eastward. Over there, Christianity had reached almost everywhere, and most of the Udmurt had no choice left than to integrate the Russian Orthodox Church into their daily lives. This does not mean that they abandoned their own ethnic religion, but they gradually absorbed elements of Christianity that became important in their identity, while retaining practices from their original traditions, which were adapted and changed in different proportions depending on the place and on the families. While only one village- 
Kuzebaevo in the Alnashi district (see Siikala \& Ulyashev 2011) - has been able to avoid Christianisation until the last decades, ${ }^{10}$ the remains of the "former worldview" are widely part of folk Orthodoxy in all parts of Udmurtia. Therefore, it is particularly enlightening to study religious practices in the regions where Christianisation did not reach Udmurt villages, and where, as we argue, the surrounding Islam shielded the Udmurt from the state-supported forceful influences. This is the case both for one village (Varkled-Bodya) in the territory of Tatarstan and for Bashkortostan.

It is highly significant that one of the places where ritual continuity has been indeed achieved, the village of Varkled Bodya, is located a few kilometres from the Udmurt territory, in the Tatar district of Agryz. It has been thoroughly studied by Estonian scholar Aado Lintrop (Lintrop 2003)11; so instead we chose to concentrate on more remote regions, in Bashkortostan. In the Tatyshly district of north-western Bashkortostan, there are several places where no interruption at all has occurred in the collective ceremonies. The more remote and difficult to access the villages were, and the further away from the Communist Party officials (not all of them were hostile though), the easier it was to avoid interference, although this explanation does not suffice to explain everything. In other places, for different reasons, there was an interruption at some point: for example, it happened that an old sacrificial priest died and did not always pass on his skills to others.

In the late period of the Soviet Union and in the first post-Soviet years, the antireligious pressure subsided and an interest for spiritual matters emerged. Where ceremonies had been performed secretly, they were now held openly, with wider and wider attendance; where they had disappeared, they reappeared. This is the process we are going to study in more detail within the limits of this two-part article, while occasionally referring to what is supposed to be a more ancient state of the tradition.

\section{THE TATYSHLY UDMURT: A BRIEF HISTORY}

According to the 2010 all-Russia census, there were 5399 Udmurt in this district out of some 20,000 in Bashkortostan, which represents $21.5 \%$ of the whole Udmurt population (Natsionalnyy 2013: 35). These Udmurt represent a particular ethno-territorial sub-group of the Eastern Udmurt, called the Tatyshly or Higher Tanyp Udmurt (from the name of the River Bystryy Tanyp, Udm. Taнbın), which emerged at the end of the seventeenth and the beginning of the eighteenth centuries and had their peculiarities in their ethnic culture and dialect. This is the region we have investigated. The histories of particular 


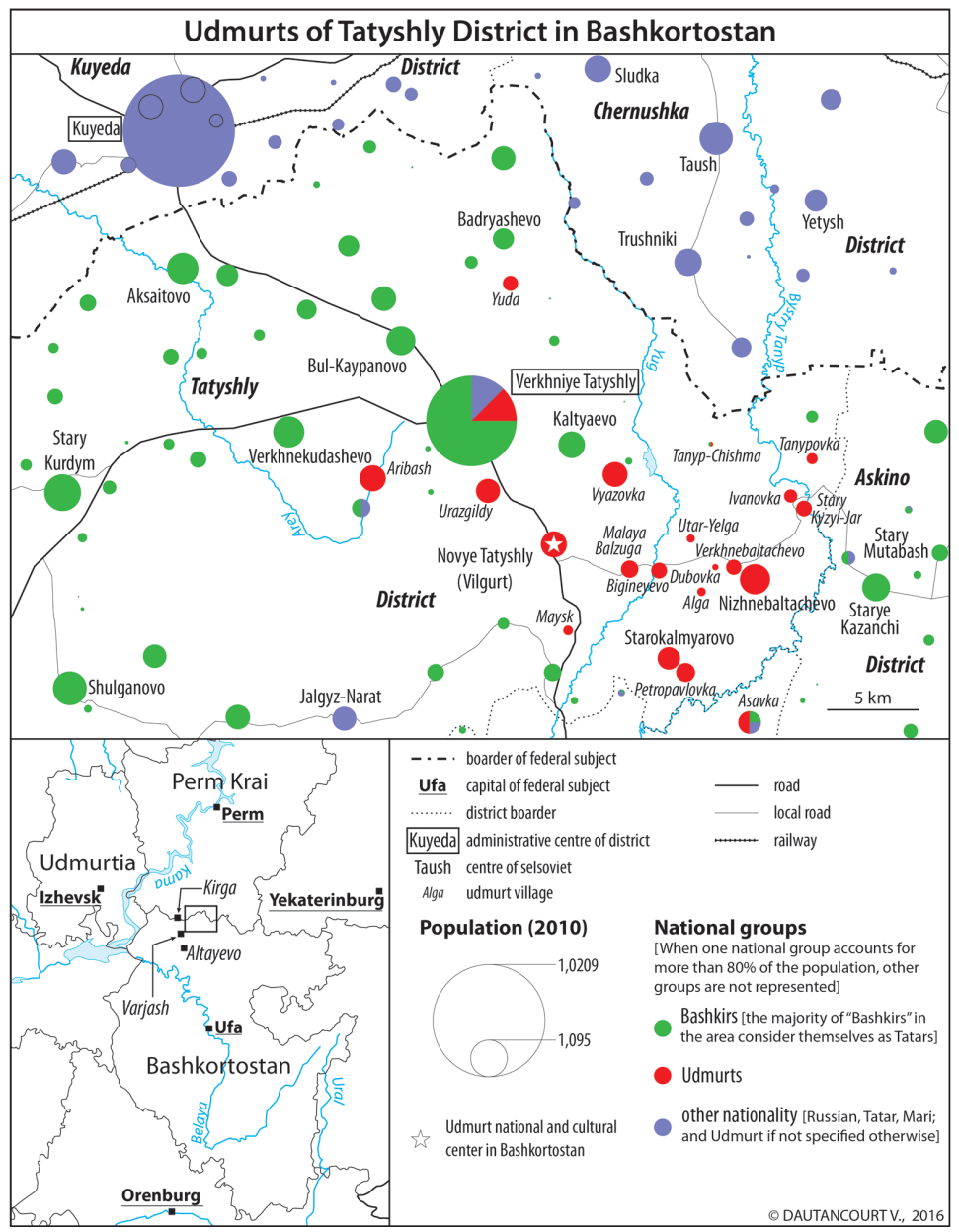

villages are longer or shorter: many of them have lasted for several hundred years. ${ }^{12}$ Thus these villages have all experienced the Soviet anti-religious policy and it may be interesting to follow the extent of the preservation of the ethnic religious practices in relation to the age of the settlement.

What is directly relevant to our subject is that the Tatyshly Udmurt are divided into two clearly distinct religious groups, which are called, according to their position in regard to the River Yug (Udm. 3 bı ), the right and the left bank group. Each organise their own collective ceremonies called mör vös ${ }^{13}$ : the right bank group organises it in the village of Novye Tatyshly (in Udmurt Vil'gurt, and that is how it will be mentioned hereafter), and the left bank in the village of Alga. The Udmurt themselves, on both banks, call their own group "(the ones) living on this bank of the Yug (Udm. Ӟъı manaлzёс) and the other 
one "(the ones) living on the other bank of the Yug" (Udm. Ӟъьк тупалъёс). ${ }^{14}$ The inhabitants of Aribash, however, differ from the others: their origins are connected with the Tanyp sub-group of the Eastern Udmurt, although today they are part of the right bank group of the Udmurt. ${ }^{15}$ We will now concentrate on the collective ceremonies of both groups, while occasionally emphasising the differences between them. These ceremonies are sacrificial events in which whole villages or groups of villages gather in order to pray to Inmar, the main god of the Udmurt, to ask for health and fertility for people and livestock, and a good harvest, as well as rain in times of drought. In this overview chapter, we will mention the historical data available, in order to give our contemporary observations some historical depth.

\section{THE CEREMONIES OF THE TATYSHLY UDMURT}

We shall here concentrate on the cycles of collective sacrificial ceremonies. There were other ceremonies more or less restricted to the private sphere, which means that they were performed within the group of the patrilineal kin; some of them are still performed. ${ }^{16}$ There are also occasional rituals connected with events in personal lives. We only mention these other rituals to show the richness and diversity of the religious life of the Tatyshly Udmurt, while, as said before, we shall concentrate on the cycles of collective sacrificial ceremonies.

Both cycles, in late spring and in late autumn, must be concluded before the solstices, and were, in the origins, as far as we know, quite symmetrical. In spring, each village organises the village ceremony, in Udmurt gurten vös' (Udm. гурт(эн) вӧсь). A while later in the Yug right bank group (also known as the Vil'gurt group) the "ceremony of three villages" kuin gurt vös' (Udm. куинь гурт вӧсь) took place, which was attended by people from Urazgildy (Udm. Vukogurt, as we shall call it hereafter), Vil'gurt, Malaya Balzyuga and Maysk (in the Soviet period the latter was inhabited by people coming from Vil'gurt and had no distinct identity in ritual activities). On the left bank of the Yug, in the so-called "Alga group", there was and there still is an intermediate ceremony, called Bagysh ${ }^{17}$ vös' (Udm. Багыıи вӧсь). This part of the cycle has been the least stable, as we shall observe hereafter. The last ceremony to be held is the mör vös' (Udm. мӧр вӧсь), in which the ten villages of the right bank of the Yug gather: Aribash, Yuda, Vyazovka, Vukogurt, Malaya Balzyuga, Maysk, Utar-El'ga, Verkhniye and Nizhniye Tatyshly as well as Vil'gurt. The villages on the left bank have also their collective mör vös' that gathers nine villages: Bigineyevo, Tanypovka, Kyzylyar, Verkhne- and Nizhnebaltachevo, Starokalmiyarovo, Petropavlovka, Alga, Dubovka. In both collective ceremonies, 
the place has been changed throughout the years. All these ceremonies were organised in the period in which the rye was in flower (Udm. зег сюрелакь).

At the end of autumn also winter village ceremonies (Udm. пол гурт вӧсь or simply тол вӧсь) and winter collective ceremonies (толлиор вӧсь) were held before the winter solstice. The villages on the left bank also have the winter Bagysh vös'.

So this is the basic cycle of the ceremonies including entire villages and groups of villages of the Tatyshly district. We shall now comment upon the changes that were brought about in the Soviet period, ${ }^{18}$ still before the wave of revitalisation of the 1990s began, and in consequence of which the cycle lost some of its symmetry.

We may add that since 2008, for the Tatyshly Udmurt as well as for the other Eastern Udmurt, the cycle is concluded after the solstice by a general ceremony attended in principle by all the villages of the region. It is called Elen vӧs' (Элен вӧсь) and it is a good example of real revitalisation, for it was held for the last time in the $1920 \mathrm{~s}$, and the memory of it was lost almost everywhere, except in the three villages where it was held (Sadikov 2010).

\section{CHANGES IN THE SOVIET PERIOD}

Changes induced by the Soviet period were of different nature and scale. Some were just consequences of the developments in agricultural techniques. For example, the rotation of the fields was abandoned. This influenced directly the praying in the spring cycle: the villages had three sacred places, the use of which was also rotating according to the direction in which the given year's rye field was. So while in former times there were three sacred places, only one remained active.

But other changes were more concretely connected with Soviet policies towards religion. During the Soviet period, it was not allowed to organise these large scale ceremonies openly, for they were seen as threatening the collective wealth due to slaughtering livestock and "wasting" working time. Thus, the sacrifice of bigger animals (oxen, horses) was discontinued, for these animals were considered as state-owned. The party and other Soviet institution's functionaries led an active fight in order to eradicate "religious vestiges". Older informants report countless cases when "bosses" popped up at the ceremonial places when the porridge was ready, and knocked over cauldrons, so that the gathered people could only go back home empty-handed. We heard these stories practically in all villages and from different informants (for example: Flyura Nurieva, Nazip Sadriev (Balzyuga); Garifulla Garifanov (Nizhnebaltachevo); 
Irina Minljaskarova (Starokalmiyarovo); Salim Shakirov (Vil'gurt) etc.). Usually, the persons who committed these deeds are said to have been "punished" later and died in non-natural ways. The sacrificial priests were summoned by the police for questioning, and they were subjected to explanatory speeches and to more or less harsh punishing measures. Nevertheless, most of them attempted, if only secretly, to keep organising all kinds of ceremonies.

The pressure of secrecy had consequences. If earlier the sacrificial ceremonies encompassing several villages were held by the biggest villages, they now held them in tiny villages, far from the administrative and kolkhoz centres. The dimensions also decreased; the ceremonies were mainly attended by elderly people. On the left bank, the mör vös' was initially held in Starokalmiyarovo, on top of a hill. In the 1960s, because of persecutions, the ceremony was transferred to a lower place. However, in 1978 the new place was flooded due to building a dam, and the villages gathered for sacrificial ceremonies not far from the small and remote village of Alga. ${ }^{19}$ The place for ceremonies was also changed in the right bank group: before 1930 it was held in Verkhniye Tatyshly, close to the source of the River Tatyshly. When the Tatyshly district was founded in 1935 , and the village became its centre, the place changed and the ceremonies started to be held in a field between Verkhniye Tatyshly and Vukogurt. Afterwards it was transferred to Vil'gurt in a gully close to the shore of the River Bolshaya Balzyuga (Udm. Пислень), where it was more difficult to notice that people had gathered.$^{20}$ In many villages, former places were abandoned and replaced by more discreet locations, where people's gatherings would not attract any undesired attention. Malaya Balzyuga is, from this point of view, a good example: the sacred grove used for the ordinary village ceremonies was visible from the main road running through the village. After a disrupting interference from the party officials, Nazip Sadriev, the sacrificial priest of Balzyuga, decided to move the sacred place just less than fifty metres further, but to a lower place closer to the spring, which was not visible from the road.

Some more changes took place. The atheist upbringing of the younger generations had some consequences, and it was hard for sacrificial priests to find successors to whom pass on their skills and knowledge. The few active sacrificial priests carried a big burden on their shoulders. This led to some adjustments, the aim of which was to ease their task. Thus, one of the most authoritative vös'as' of the Tatyshly district, Nazip Sadriev, who was one of our main informers, initiated some changes: among the most radical ones was to leave out of the ritual calendar the ceremony conducted by the three villages on the right bank. Several reasons explain this choice: on the one hand, the priest himself was getting older and older; on the other hand, as he explained himself, the expenses of buying a ewe for this ceremony were becoming unbearable for the 
community, which in the same period had to buy a lamb for the village ceremony and one for the 10 villages' mör vös'. There were also changes in the proceedings of the ritual, and we shall dwell on them further on.

In the second part of the article in the next issue of the journal we will comment on the transformations of the post-Soviet period and of recent years.

\section{NOTES}

1 Or Trans-Kama Udmurt; in Russian ‘закамские удмурты', in Udmurt 'камсьӧр удмуртъёс'.

${ }^{2}$ However, the reasons for leaving their original villages, the territory of which is now part of the Republic of Udmurtia, were manifold (and comparable to those that led the Mari to the same kind of migration; see Yamurzina 2013: 113-116). The Mari also are still there, outnumbering five times the Udmurt in Bashkortostan.

3 We shall not here detail the proceedings of the ceremonies. Eva Toulouze and Liivo Niglas have published an ethnography about it, which gives the necessary details (see Toulouze \& Niglas 2014).

4 Since 2013 the authors have made common fieldwork in the framework of the projects DFLKU14509, PUT590, and PUT712 of the Estonian Science Foundation, as well as the Institut Universitaire de France.

5 Bernát Munkácsi visited the Birsk uyezd, now Yanaul district, in 1885 (see Sadikov \& Minniyakhmetova 2012).

6 We refer to Yrjö Wichmann (1894), Axel Heikel (1884) and Uno Holmberg [Harva] (1911), who carried out fieldwork among the Eastern Udmurt in the Birsk uyezd; we also refer to Heikel and Wichmann's fieldwork in the Kaltasy and Yanaul districts as well as Holmberg's [Harva] observations in the Osin uyezd (now Kueda district, in the Perm Krai).

7 For example, the fencing of ritual sites is not unheard of: in different regions of the area inhabited by the Udmurt, and in a certain period in history sacred places may indeed have been fenced.

8 We have been working in the field as follows: in 2011, a pilot one-day visit by Ranus Sadikov and Eva Toulouze; June 2013 Eva Toulouze, Liivo Niglas, and Ranus Sadikov; December 2013 Eva Toulouze and Liivo Niglas; June 2014 Eva Toulouze, Liivo Niglas, and Laur Vallikivi; June 2015 Eva Toulouze and Ranus Sadikov; November 2015 Eva Toulouze, Liivo Niglas, and Ranus Sadikov; June 2016 Eva Toulouze, Nikolai Anisimov, and Ranus Sadikov; December 2016 Eva Toulouze, Liivo Niglas, Nikolai Anisimov, and Ranus Sadikov; June 2017 Eva Toulouze, Laur Vallikivi, Nikolai Anisimov, and Ranus Sadikov; October 2017 Eva Toulouze, Liivo Niglas, and Nikolai Anisimov; April 2018 Eva Toulouze and Laur Vallikivi; June 2018 Eva Toulouze and Ranus Sadikov.

9 As well as German scholar Sonja Luehrmann (2011) on Mari religion, more precisely on atheism in Mari El. 
${ }^{10}$ Over recent decades there have been some baptisms, both into the Orthodox Church and into Protestant denominations, but this has not significantly affected the identity of the larger group.

${ }^{11}$ In English: Lintrop 2002, 2004, 2006, 2007, 2008.

12 The first data are from 1670, referring to the villages of Baltachevo and Kalmiyarovo, while Tetysh village (today Verkhniye Tatyshly) is mentioned in 1703 (Asfandiyarov 1994: 35-38). Other villages are mentioned in 1723: Starokalmiyarovo, Nizhnebaltachevo, Bigineyevo, Staryy Kyzylyar (RGADA 1723). Other villages were formed in the following decades and centuries: Aribash (1743), Nizhniye Tatyshly (1768), Urazgildy (beginning of the nineteenth century), Novye Tatyshly (1849), Malaya Balzyuga (1878), Yuda (1896), Vyazovka (1922), Tanypovka (1924), Mayskiy (1924), Alga (1927), etc. (Zaydullin \& Zaydullin 1999).

${ }^{13}$ It is one of the ceremonies of the spring and autumn cycles.

${ }^{14}$ R. Sadikov's fieldwork materials 2003, Vil'gurt village, Tatyshly district, Khabrislam Khabibyanov, born in 1933.

${ }^{15}$ According to elderly informants, the right bank collective ceremonies were also attended by the Udmurt of Chikashevo (today Tatarskiye Chikashi in the Kuyeda district, Perm Krai). Fieldwork materials 2016, Nazip Sadriev, born in 1930 (Malaya Balzyuga). R. Sadikov visited the Tatyshly Udmurt in 1997, 2000, 2003, 2004, 2009, 2010 .

${ }^{16}$ This is the case of the so-called Great Day (Udm. Быљӟьнал), the starting of the New Year, which coincides with the Orthodox Easter (Minniyakhmetova 2000: 22). Other ceremonies took place in the clan's sacred building, the kuala, which practically does not exist anymore, except in some rare places, like kualae pyron (Udm. куалае пьюрон) around Pentecost, in which birch branches were put on the sacred shelf and the old ones were burnt (fieldwork materials of R. Sadikov from 2000: Shabrika Garibzanova, born in Vil'gurt in 1902) and from 2009: Farkhana Badredtinova, born in Kyzylyar in 1928). Another family ceremony was the autumn prayer (Udm. сӥзььл куриськон), after the harvesting season. Fieldwork materials of Ranus Sadikov from 2000, Maysk, Tatyshly district of the Bashkortostan Republic; Anastasiya Samysheva, born in 1924; fieldwork materials of Ranus Sadikov from 2009, Kyzylyar; Farkhana Badredtinova, born in 1928.

17 The capital initial letter is explained by the interpretation of this word: it is supposed to be the name of the owner of the field where the ceremony was held.

${ }^{18}$ At least on the basis of the material we have been able to gather. The only source we have is the memories of older people, and what we are going to present is not the result of direct observation or archival data, but of human remembrance. There may have been other changes nobody ever mentioned; the event recalled may have been remembered in different ways by different witnesses. So our following chapter cannot be taken as a positivist description of what happened, but as a synthesis of what we were able to collect.

${ }^{19}$ Fieldwork materials of Ranus Sadikov from 2000, Starokalmiyarovo, Tatyshly district of the Bashkortostan Republic; Boris Kostin, born in 1939. 
${ }^{20}$ Fieldwork materials of Ranus Sadikov from 2003, Novye Tatyshly, Tatyshly district of the Bashkortostan Republic; Salim Shakirov, born in 1938.

\section{ARCHIVAL MATERIALS}

RGADA 1723 = Russian State Archive of Ancient Documents, fund 350, list 2, folder 3790. Knigi perepisnye iasachnykh krest'ian i bobylei (mari, udmurty, tatary, chuvashi, mordva) Osinskoi, Kazanskoi, Nogaiskoi i Sibirskoi dorog Ufimskogo uezda. [The Census Books of the Yasak Peasants and Landless Peasants (Mari, Udmurt, Tatar, Chuvash, Mordva) of Osinsk, Kazan, Nogai and Siberian Roads of the Ufim Uyezd.]

\section{REFERENCES}

Asfandiyarov 1994 = Asfandiiarov, Anvar. Istoriia sel $i$ dereven' Bashkortostana: Spravochnik. [The History of Hamlets and Villages of Bashkortostan: Reference Book.] Vol. 5. Ufa: Kitap.

Holmberg [Harva], Uno 1914-1915. Permalaisten uskonto. [The Religion of the Permians.] Suomensuvun uskonnot 4. Porvoo: WSOY.

Kel'makov 1974 = Kel'makov, Valentin. Fonema ə v tatyshlinskom dialekte udmurtskogo iazyka. [The Phoneme ə in the Tatyshly Dialect of the Udmurt Language.] Sovetskoe finno-ugrovedenie, Vol. 10, No. 2, pp. 101-106.

Lintrop, Aado 2002. The Spring Prayer Feasts in the Udmurt Village of Varklet-Bodya in Tatarstan. Cosmos: The Journal of the Traditional Cosmology Society, Vol. 18, pp. 43-55. Available at https://thisisthetcson.files.wordpress.com/2016/07/ cosmos-18.pdf, last accessed on 5 July 2018.

Lintrop, Aado 2003. Udmurdi usund. [Udmurts' Religion.] Tartu: Eesti Rahva Muuseum. Lintrop, Aado 2004. On the Udmurt Water Spirit and the Formation of the Concept 'Holy' among Permian Peoples. Folklore: Electronic Journal of Folklore, Vol. 26, pp. 7-26. http://dx.doi.org/10.7592/FEJF2004.26.lintrop.

Lintrop, Aado 2006. Liminal Periods in the Udmurt Ritual Year. In: George MifsudChircop (ed.) First International Conference of the SIEF Working Group on the Ritual Year. Proceedings. Malta, March 20-24, 2005. Malta: Publishers Enterprises Group, pp. 362-372. Available at http://folklore.ee/ aado/liminal.pdf, last accessed on 5 July 2018.

Lintrop, Aado 2007. The Midsummer Prayers in the Udmurt Village of Kuzebayevo. In: Lina Midholm \& Annika Nordström (eds.) The Ritual Year and Ritual Diversity. Proceedings of the Second International Conference of the SIEF Working Group on the Ritual Year, Gothenburg: Institute for Language and Folklore, pp. 39-44.

Lintrop, Aado 2008. Commemoration of the Dead as Part of the Udmurt Ritual Year. In: Irina Sedakova (ed.) The Ritual Year 3. The Ritual Year and History. Proceedings of the Third International Conference of the SIEF Working Group on the Ritual Year. Strážnice: Narodni ústav lidové kultury, pp. 126-132. 
Luehrmann, Sonja 2011. Secularism Soviet Style: Teaching Atheism and Religion in a Volga Republic. Bloomington: Indiana University Press.

Minniyakhmetova 2000 = Minniiakhmetova, Tat'iana. Kalendarnye obriady zakamskikh udmurtov. [The Calendar Rites of the Trans-Kama Udmurts.] Izhevsk: UIIIaL UrO RAN.

Natsionalnyy 2013 = Natsional'nyi sostav i vladenie iazykami, grazhdanstvo naseleniia Respubliki Bashkortostan po dannym Vserossiiskoi perepisi naseleniia 2010 goda: Statisticheskii sbornik. [The National Composition, Language Knowledge, Citizenship of the Population of the Bashkortostan Republic According to the Data of the All-Russian Census of 2010: A Statistical Collection.] Vol. I. Ufa: Bashkortostanstat.

Niglas, Liivo 2016. Videodokumentirovanie derevenskogo moleniia zakamskikh udmurtov. [Video Documenting of the Village Prayers of the Trans-Kama Udmurts.] In: E. Arinin (ed.) Akademicheskoe issledovanie i kontseptualizatsiia religii v XXI veke: traditsii i novye vyzovy. Vladimir: Vladimirskii gosudarstvennyi universitet, p. 161.

Sadikov 2010 = Sadikov, Ranus. Elen vös' - "molenie stranoi": Zhivaia drevnost' na prostorakh Bashkirii. [Elen vös' - "The Prayer of the Country": A Living Antiquity in the Wastes of Bashkiria.] Vordskem kyl, No. 7, pp. 34-35.

Sadikov, Ranus 2011. Religioznye verovaniia $i$ obriadnost' zakamskikh udmurtov (sokhranenie i preemstvennost' traditsii). [The Religious Beliefs and Rituals of the Trans-Kama Udmurts (the Preservation and Continuity of Traditions).] Extended summary of the doctoral dissertation. Izhevsk. Available at https://www. prlib.ru/item/361985, last accessed on 5 July 2018.

Sadikov \& Minniyakhmetova 2012 = Sadikov, Ranus \& Minniiakhmetova, Tat'iana. Zarubezhnye issledovateli etnografii, fol'klora i iazyka zakamskikh udmurtov: istoriograficheskii ocherk. [Foreign Researchers of the Ethnography, Folklore and Language of the Trans-Kama Udmurts: Historiographical Study.] Ezhegodnik finno-ugorskikh issledovanii, No. 4, pp. 49-62. Available at http://cyberleninka. ru/article/n/zarubezhnye-issledovateli-etnografii-folklora-i-yazyka-zakamskihudmurtov-istoriograficheskiy-ocherk, last accessed on 5 July 2018.

Siikala, Anna-Leena \& Ulyashev, Oleg 2011. Hidden Rituals and Public Performances: Traditions and Belonging among the post-Soviet Khanty, Komi and Udmurts. Studia Fennica Folkloristica 19. Helsinki: Finnish Literature Society. https:// doi.org/10.21435/sff.19.

Toulouze, Eva \& Niglas, Liivo 2014. Udmurt Animist Ceremonies in Bashkortostan: Fieldwork Ethnography. Journal of Ethnology and Folkloristics, Vol. 8 (1), pp. 111-120. Available at http://www.jef.ee/index.php/journal/article/view/176/_1, last accessed on 6 July 2018.

Yagafova et al. 2010 = Iagafova, Ekaterina \& Danilko, Elena \& Kornishina, Galina \& Molotova, Tamara \& Sadikov, Ranus. Etnokonfessional'nye men'shinstva narodov Uralo-Povolzh'ia. [Ethno-Confessional Minorities among the UralVolga Peoples.] Samara: Izd-vo PGSGA. Available at http://www.ikuzeev.ru/ sites/default/files/Ethnokonfessionalhye\%20menshinstva\%20narodov\%20uralopovolzhja.pdf, last accessed on 6 July 2018. 
Vladykin, Vladimir 1994. Religiozno-mifologicheskaia kartina mira udmurtov. [The Religious-Mythological Worldview of the Udmurts.] Izhevsk: Udmurtiia.

Yamurzina, Ljudmila 2013. L'origine des Maris orientaux. In: Eva Toulouze \& Vincent Lorenzini (eds.) Les Maris, un people finno-ougrien de Russie centrale. Paris: L'Harmattan/ADEFO, pp. 109-124.

Zaydullin \& Zaydullin 1999 = Zaidullin, R. \& Zaidullin, A. Raionys' udmurt gurt"eslen kyldemzy. [The Emergence of the Udmurt Villages of the District.] Az'lan'(Verkhnie Tatyshly), No. 46, 47, 49. 


\title{
HUMOR MAKES LIFE MORE TOLERABLE. INTERVIEW WITH AMERICAN FOLKLORIST TREVOR J. BLANK
}

\author{
Interviewer Henri Zeigo
}

\section{Books published by Trevor J. Blank}

Slender Man Is Coming: Creepypasta and Contemporary Legends on the Internet, 2018 (edited by Trevor J. Blank and Lynne S. McNeill)

Diagnosing Folklore: Perspectives on Disability, Health, and Trauma, 2015 (edited by Trevor J. Blank and Andrea Kitta)

Maryland Legends: Folklore from the Old Line State (American Legends), 2014, by Trevor J. Blank and David J. Puglia

Toward a Conceptual Framework for the Study

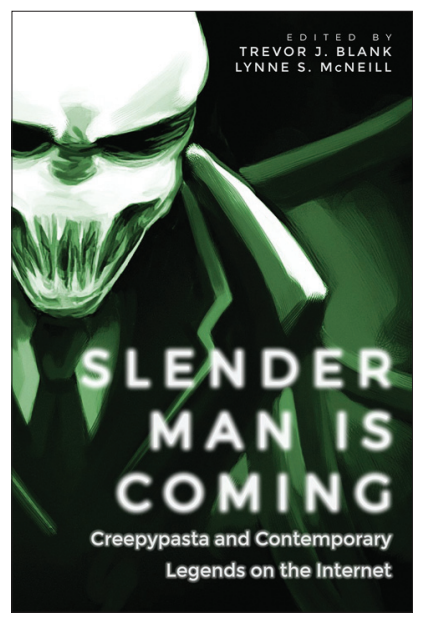
of Folklore and the Internet (Current Arguments in Folklore), 2014, by Trevor J. Blank

The Last Laugh: Folk Humor, Celebrity Culture, and Mass-Mediated Disasters in the Digital Age (Folklore Studies in a Multicultural World), 2013, by Trevor J. Blank

Tradition in the Twenty-First Century: Locating the Role of the Past in the Present, 2013 (edited by Trevor J. Blank and Robert Glenn Howard)

Folk Culture in the Digital Age: The Emergent Dynamics of Human Interaction, 2012 (edited by Trevor J. Blank)

Folklore and the Internet: Vernacular Expression in a Digital World, 2009, by Trevor J. Blank

Spring Grove State Hospital (Images of America: Maryland), 2008, by David S. Helsel, M.D., and Trevor J. Blank 
There was the International Society of Humor Studies conference in Tallinn (25-29 June) where American folklorist Dr. Trevor J. Blank presented his latest research topic called "How the Mighty Have Fallen: American Celebrity Scandals and Humor Dynamics Online" (https:// youtu.be/8mSUD61TKFg). Dr. Blank is associate professor of communication at the State University of New York at Potsdam. He is the editor of Folklore and the Internet and Folk Culture in the Digital Age, and author of The Last Laugh: Folk Humor, Celebrity Culture, and MassMediated Disasters in the Digital Age.

In the light of Dr. Blank's recent research, the Estonian Literary Museum conducted an interview with him in order to examine some crucial aspects of his work and ask about his approaches to his field of study.

Trevor Blank, how did you become interested in folklore studies?

I became interested in folklore studies as an undergraduate at the University of Maryland, Baltimore County. I met the former state folklorist by the name Charley Camp who was teaching a class about American folk life there. I sat in on his class and was really interested in his discussion of ethnography, which I was not really familiar with up to that point. So I befriended him. He invited me in his house a few times and shared books with me and articles that he thought I would find interesting. Originally, I was working towards becoming a high school social studies teacher, but I soon felt disillusion with that career path. So it was Charley who recommended that I go to Indiana University for graduate school to study folklore. I got my master's degree there in 2007. However, because I wanted to study internet culture for my doctoral dissertation, which my advisors generally did not consider to be a serious area of study, I ended up at Penn State University where I finished my Ph.D. in American Studies with a concentration on folklore. I have been studying internet culture ever since, because it embraced my research interests in the subject and helped instill the confidence I needed to pursue it.

Was there any sign that appeared in your early childhood which showed the way to your future career?

When I was a kid, I loved telling stories. One time in the 3rd grade I got into trouble for telling a dirty joke to my friends. I will tell you as best I can remember it ... there is a young boy who was walking around his neighborhood one day. An older woman was standing in her doorway and said: "Come inside." The boy said: "My mommy told me not to and I do not think I want to." She said: "I will give you three cookies if you come with me." The boy agreed to go. 


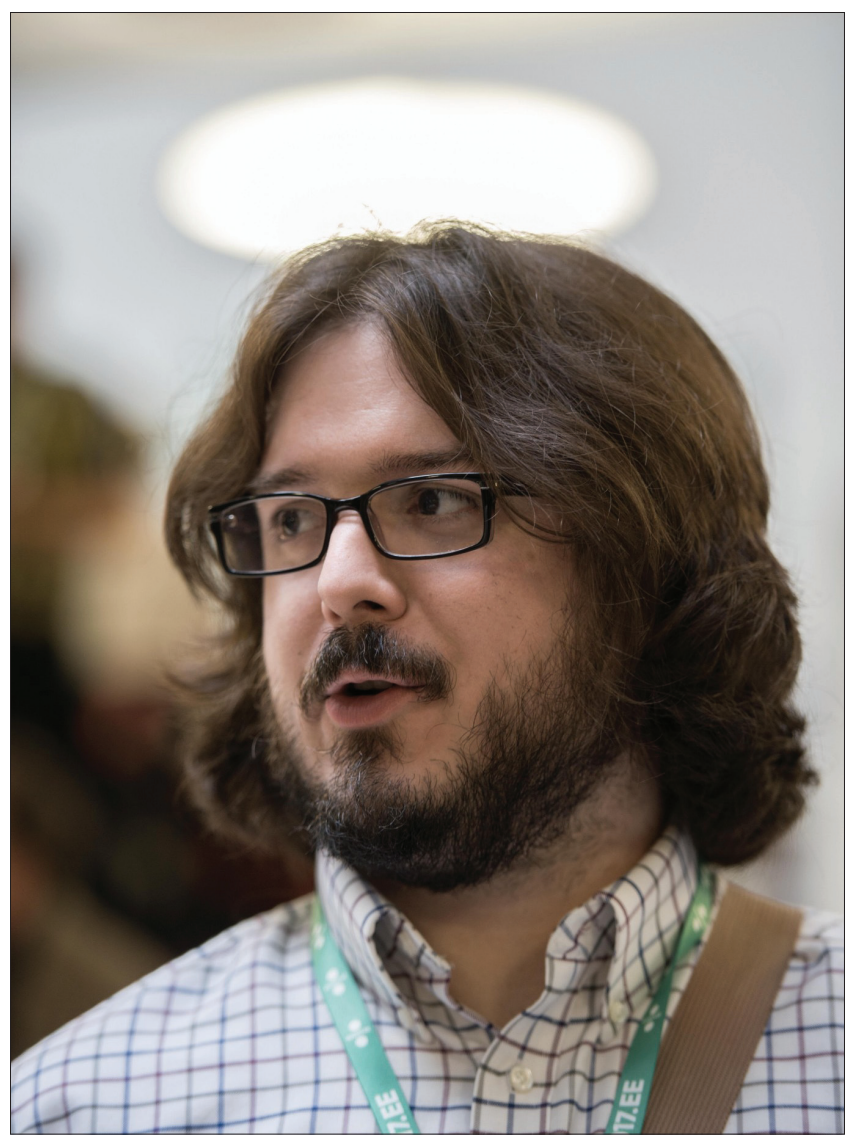

Trevor J. Blank. Photograph by Alar Madisson 2018.

Now the older lady said: "Come upstairs with me!" The boy said: "My mommy told me not to and I think I do not want to." The woman promised to give five cookies this time if he agrees to come upstairs. So the boy went upstairs. After that the older woman urged the boy to sit on her bed. The boy answered as before and the woman had to give him ten cookies for him to agree. Then the lady asked him to climb on top of her. The payment for saying yes was twenty cookies this time. So the boy goes on top of her and they start to wrestle. Suddenly, the woman's husband comes home and starts to yell: "Get off my wife!" to which the boy says "My mommy told me not to and I think I do not want to." (laugh) ... This was the first time I remember getting into trouble for telling a joke. I was hooked. I have always been interested in collecting dirty jokes that 
people are embarrassed to tell in front of the others, because humor allows to broach sensitive and taboo subjects out in the open while revealing a great deal about the human condition and how to respond to the trials and tribulations of everyday life. As a folklorist, I am especially interested in how people make meaning in everyday life.

\section{What kind of jokes were generally popular in your childhood?}

A lot of jokes that I can remember were like songs where the existing melody was mixed with the lyrics about authorities that we knew. By the time I went to college and started to collect jokes, I started to become acutely aware of political jokes and figures that were subjects of parody.

Your recent research topic is about American celebrity humor. What makes jokes about American celebrities so unique when compared to the rest of authorities?

In America, the celebrities are like royalty. We put them on the pedestal and give them an exalted status within society. Because of their privileged status they are a great target for jokes. It is fun to take them down and poke holes in their public persona. Lots of jokes are about celebrities, because it seems that they have all. They have a great life, they are financially stable and loved by lots of people. Everybody wants to become rich and famous in America, but most people will not reach huge levels of success in the way that celebrities do. We project a lot of our hopes and dreams onto them. We follow them and we think of them almost like an extension of us. When celebrities betray us, such as with a scandal or the committing of a crime, we try to symbolically keep our distance from them. Humor is one way to say: "I do not appreciate what are you doing." A great example would be Bill Cosby. Bill Cosby was a celebrated comedian, known in the 1960s and 70s for his stand-up comedy, and in the 1980s for his widely popular television show in which he was the star. People loved him and thought of him as a fatherly character in American society. And then we came to know that there are some serious allegations against him that span decades, which we only recently learned about: that he has been allegedly sexually assaulting women. One of the best ways to express rage is through humor.

It seems that American celebrities need attention in order to be famous. Can humor make somebody more popular than he was before?

Most of the jokes that I collect about celebrities are about individuals who have already attained that status. My expertise falls under humor that works to take a celebrity down rather than build them up. Take, for example, Amy Winehouse. 


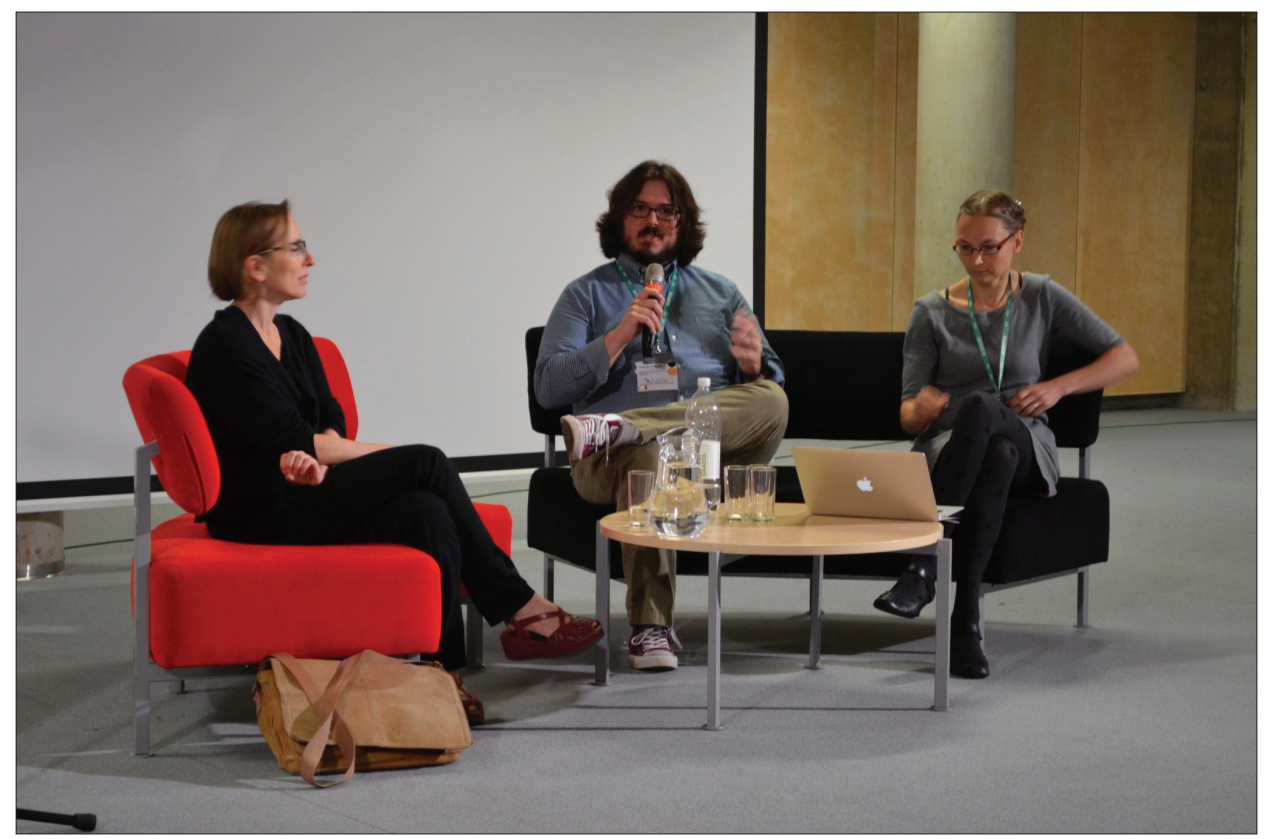

Limor Shifman, Trevor J. Blank, and Liisi Laineste discussing internet humor at the ISHS conference at Tallinn University on 28 June 2018. Photograph by Piret Voolaid 2018.

She was a singer known for her raw talent, but also for her problems with drug and alcohol abuse. So lots of jokes about her that followed her death focused on her addictions. When she died, a lot of people did not have compassion for her, because they felt that her death was her own doing.

Can humor also affect policy-making? For instance, there were lots of dirty jokes about Donald Trump, but suddenly he managed to win in an upset in the last American election.

It is an interesting case, because it has a lot to do with the power of social media. People liked Trump, because they believed he would shake the system and would provide a new way of governing. There were lots of jokes about how he speaks and acts, as well as about his mannerisms. I still find them funny.

There is a saying in America that we call the middle part of the United States "fly over the country". That is the big area in the middle of the country where planes typically fly over, but do not stop. People who were living there 
were afraid that they were losing their way of life and that they were seen as unimportant. In the eyes of their government, Trump, for them, symbolically embodies what America is for them. Humor was used to take him down, but his voters did not live in major media markets. They lived, for example, in places like Nebraska, which you may have never heard about.

What do you think about the Harvey Weinstein case? It seems that celebrities started this campaign called \#MeToo and somehow the folk took it over.

Rose McGowan is probably the most prominent American celebrity who started the \#MeToo movement by talking about her encounters with Harvey Weinstein. She used her platform on Twitter to say: "It happened to me, I am a woman, and these things happen to women commonly." She also got some feedback from males who did not pay enough attention to what she said. This spurned the folk into action. Other women also came forward to share their experiences and say openly that this was not a story that only happens to famous people; it also happens to common people.

In college campuses in the United States one out of five students has experienced some form of sexual assault during their college years. Celebrity culture used their exalted status to create a platform for public discussion so that other women could come out and talk about their stories.

\section{Does humor have power to make society better?}

Yes, it does. I think humor makes life more tolerable. There is a saying in America: "Death is certain, but life is not."

In different societies there are various understandings of what is racial, religious, and sexual humor. Do you think that humor should have some sort of limits?

I do not think there should be limits for humor. Recently, I had a student who was really upset that I assigned an article about suicide humor for a folklore class that I was teaching. This student felt that it was morally wrong that I assigned such a reading. I had to politely explain why this was important and why this was an area we should study, because these things exist whether we acknowledge them or not. I think studying all forms of humor is valuable, regardless of whether it is good or bad. There should not be criteria for what humor should or should not be studied, because all kinds of humor help us to understand the human condition and how people respond to different stresses in life, or provide insights into how people play with one another. As a folklor- 
ist, I am interested in how people express themselves in everyday life. I am interested in all aspects of humor. For instance, I collected $\mathrm{Ku}$ Klux Klan humor in the past. And it is not kind or good. Nevertheless, I learned a great deal about one segment of the American population. Humor can even provide a window into understanding some secret aspects of life. Things that people do not want to talk about openly. Thereby we can learn more about the nature of race, gender, etc.

So humor alleviates stress in some kinds of problems that need to be solved in society too?

Yes, I think it is fair to say so.

\section{Have you had any new research topics recently?}

Well, I have now an 18-months-old son who has kept me quite busy. Mostly, I have been continuing my work on digital culture. I am working on an edited collection called "Folklore and Social Media". That is going to be a new book which continues the discussions in my previous edited collections about how people express themselves through digital technologies. I do not sleep much anymore, because I work all the time, but it is lots of fun and I like it.

Kids can also be the subject of examining humor. Have you learnt something from your own child?

This is one of the things why I like being a dad. My son does not say really much yet; he acts out and points to stuff and laughs. It is so much fun to be a parent.

\section{During your stay in Estonia, have you found something noticeable or funny here?}

In America it is quite normal to smile - even at a stranger when you pass each other on the street. But when I was in Estonia and said hello to a stranger with a smile on my face, the person stared back at me rather awkwardly and seemed very confused, because he did not know me. I do not know if it was a coincidence or not, but I must be very careful not to smile so often here (laughs). Smiling is something very natural for me when communicating with others. For example, when I go to an elevator, normally I smile and make eye-contact with the other individuals who are riding along. 


\section{NEWS IN BRIEF}

\section{FOLKLORISTS AS PARTNERS IN AN INTERNATIONAL COOPERATION PROJECT OF SUSTAINABLE RURAL TOURISM}

On 25-27 February 2018, the team of the Nordplus project "Sustainable Tools 4 Trainers" (T4T) held its concluding meeting in Klaipeda, Lithuania, where the final results of the project were presented to the target group and plans for follow-up projects were made.

The project (2016-2018) joined six organisations from Iceland, Estonia, Latvia, Lithuania, and Finland, who as a consortium aimed to collaborate to develop adult education materials under the heading "Tools for Trainers in Sustainable Tourism". The role of the Estonian Folklore Institute was to give expert advice in how to involve local folklore and traditions in the tourism experience offered by rural tourism enterprises.

The kick-off meeting of the project took place in Sandgerði (Iceland), on 23-26 August 2016 , and laid the foundations for further work. The aim of the project was to promote innovation, and to exchange experience and know-how between various types of organisations in Nordic and Baltic countries involved in adult education, venturing to support

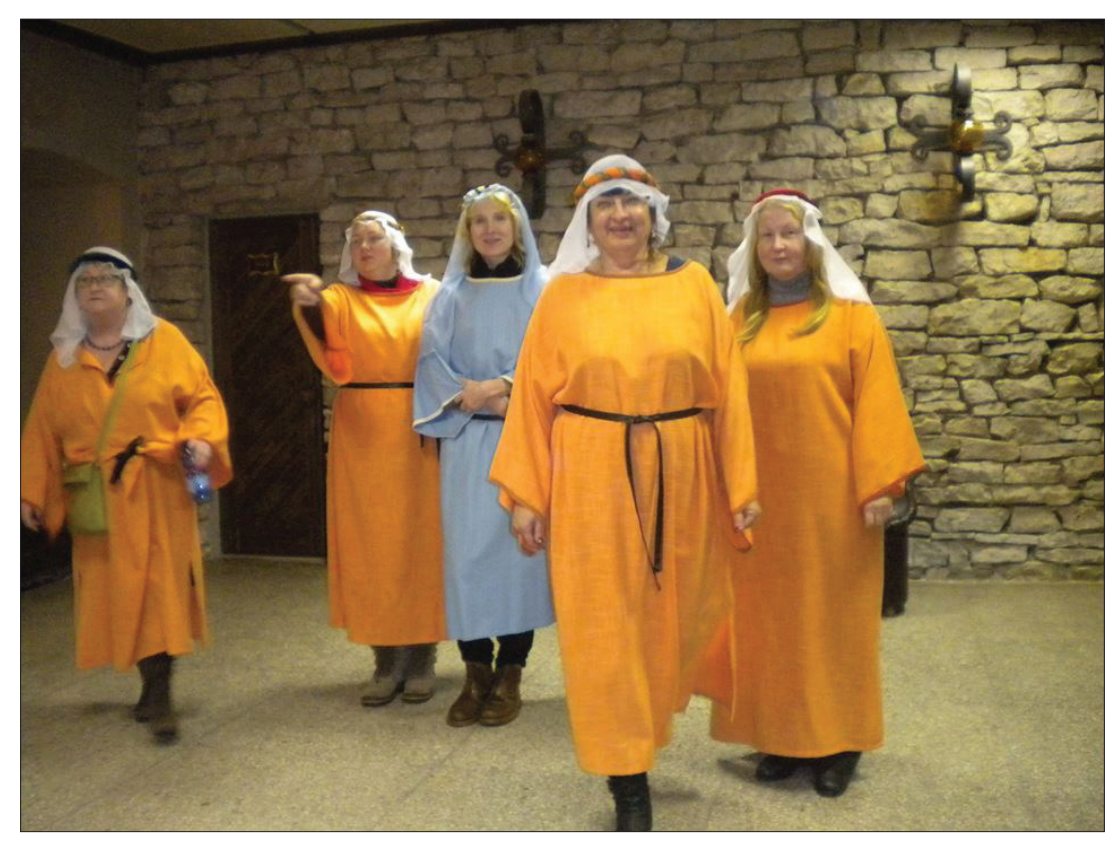

The project team merged from top to toe into the medieval traditions of the Jaunpils Castle, Latvia. Photograph by Jukka Kallio 2017. 
the creation and dissemination of best practices in rural tourism. The main tangible result of the project is a topical online toolbox (https://t4t.yolasite.com) - a collection of materials and best practice examples from the project partners and other organisations. These tools can be used as a practical instrument in the work of adult educators in project partners' and other stakeholders' organisations, and also disseminated among a wider audience.

During the second project meeting in Riga (Latvia) in 2017, the project team put together a plan for creating the toolbox and divided the work between project partners. The role of the Estonian representative Reet Hiiemäe was to prepare illustrated materials about the possibilities of using nature and place lore, local folk belief and legends, and traditional celebrations of holidays in contemporary rural tourism. The third project meeting in Nelijärve (Estonia) in 2017 enabled us to get feedback from the target group and continue developing the toolbox in a more clearly focused way (e.g. adding short training videos). We hope that the toolbox will help to increase the quality of rural tourism services and the competences of the participants as well as the project target group.

Reet Hiiemäe

\section{INTERNATIONAL CONFERENCE OF HUMOUR RESEARCHERS IN TALLINN}

On 25-29 June 2018, the conference of the International Society for Humour Studies (ISHS), under the heading "Humour: Positively (?) Transforming", took place in the Astra building of Tallinn University, Estonia. The conference assembled 265 scholars from 38 countries, with an aim to analyse the essence of humour and its expressions. The conference started on 25 June with a doctoral seminar day (jointly with the GSCSA Graduate School of Culture Studies and Arts - and Tallinn University). 98 people attended the doctoral school, with university students having prioritised participation.

Humour reacts to changes in society flexibly, bluntly, and quickly, providing unexpected insights into problematic issues, such as migration, censorship, intolerance, stereotyping, etc. The five conference days dwelt on topical issues which could also be of interest to a wider audience, and every day open lectures, plenary sessions, and workshops took place.

Four plenary speeches were given at the conference: Jessica Milner Davis, Australian sociologist and culture theorist, talked about why political satire has gained more and more popularity throughout times, and why humour about Donald Trump has both raised and lowered his status. After the plenary speech, Jessica Milner Davis was awarded the lifework prize by the ISHS.

US folklorist Elliott Oring showed how humour can be studied with the help of universal global theories and scripts. 
US folklorist Trevor Blank, whose main research domain is internet humour, talked about scandals concerning Bill Cosby and other celebrities, which have a strong humour potential.

Israel sociologist Limor Shifman was interested in quickly globalising humour. One of the carriers of this trend is memes spreading all over the internet, and Shifman's research is concerned with their differences by cultures.

A separate session on 27 June was dedicated to the connection between humour and artificial intelligence. The discussion group tried to find out whether artificial intelligence is able to joke like humans and also understand jokes or whether humour created by artificial intelligence would be more understandable mainly among other artificial intelligences.

On 29 June, recognised scholars of different domains discussed the specific features of Estonian humour on the basis of Andrus Kivirähk's novel "The Man Who Spoke Snakish”. Does a foreigner regard this book as funny or as tragic? How do people from other countries characterise Estonians' sense of humour?

In addition to a number of special panels, one three-session-long panel dedicated to Christie Davis took place. For the first time Christie Davis's award was handed out; it was given to Hannah Baldwin from the United Kingdom, who delivered a plenary lecture on Philogelos's compatibility with Davis's theories of humour.

Researchers of the Department of Folkloristics of the Estonian Literary Museum (ELM) also made several presentations: researcher Saša Babič (What is the Difference Between an Orchestra and a Cow? Exploring the Idiosyncrasy of Musicians' Humour), researcher Reet Hiiemäe (Negotiating Personal Spirituality Through Humour), senior researcher Mare Kalda together with Astrid Tuisk (School Memes: The Estonian Case), senior researcher Liisi Laineste (Joke Tales and Their Targets: The Clergy in Estonian Jokelore), and Piret Voolaid together with Kalle Voolaid (Sports Commentators' Gaffes as a Type of (Un)Intentional Humour in Estonia).

The main organiser of the conference was Liisi Laineste, senior researcher of the Department of Folkloristics of the ELM, and the secretary Anastasiya Fiadotava; the members of the organising committee were Carlo Cubero, Mikhail Fiadotau, Mare Kõiva, Anne Ostrak, Kristel Toom, and Piret Voolaid.

The homepage of the conference can be found at https://www.folklore.ee/rl/fo/konve/ ishs2018, and in Facebook (ISHS 2018).

The conference was organised by the Estonian Literary Museum, the Centre of Excellence in Estonian Studies, and Tallinn University, and it was supported by the European Union through the European Regional Development Fund (Enterprise Estonia, Centre of Excellence in Estonian Studies), the Estonian Research Council (research project IUT 22-5), and the Estonian Cultural Endowment.

Piret Voolaid, Liisi Laineste 


\section{BOOK REVIEW}

\section{A STUDY OF HUMAN-NATURE RELATIONS}

Vladimir Davydov, Veronika Simonova, Tatyana Sem, Donatas Brandishauskas. Ogon', voda, veter $i$ kamen'v evenkiiskikh landshaftakh: Otnosheniia cheloveka i prirody v Baikal'skoi Sibiri. St. Petersburg: MAE RAN, 2016. 196 pp. In Russian.

This Russian-language monograph titled Ogon', voda, veter $i$ kamen'v evenkiiskikh landshaftakh: Otnosheniia cheloveka $i$ prirody v Baikal'skoi Sibiri (Fire, Water, Wind, and Stone in the Evenki Landscapes: Human-Nature Relations in the Baikal Siberia) examines the relationship between the Evenki of the Baikal area in Siberia and their natural environment. Water, wind, stone, and fire as natural phenomena are cru-

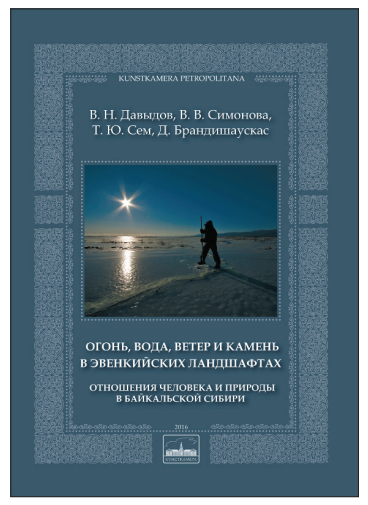
cially important for the life of any living being. The study of these phenomena can contribute to a more nuanced understanding of how people in different contexts experience themselves and the worlds in which they live.

One cannot say that the relations between humans and nature have not been of interest to Russian/Soviet ethnologists. These relations were understood by the Soviet ethnography of the 1960s-1970s mainly from a retrospective point of view. Scholars studied indigenous peoples by tracing their relations with nature according to "traditional" economic and religious life. For example, an excellent collection of papers edited by Innokenti Vdovin was devoted to the northern indigenous peoples' ideas about nature, soul, and death, as well as shamanic worldview and practices dating back to the middle of the 19th and beginning of the 20th centuries (Vdovin 1976). Since the 1980s these relations have been studied within the framework of a new sub-discipline called ethnic ecology (etnicheskaia ekologiia; ethnoecology), which was developed by the leading research scholars from the Institute of Ethnography of the Academy of Sciences of the USSR, and was influenced by the cultural ecology of J. Stuart. A special department concerned with ethnoecology has been working within the framework of this institute since 1981, studying different problems; for example, the phenomenon of longevity among the Caucasus population, the influence of radiation on the local population of the Ural region, problems of the ethnoecological expertise, and some others (Yamskov 2013). Contemporary problems connected with pollution, land rights, and use of resources received much attention under the new socioeconomic and ecological conditions at the end of the 20th and beginning of the 21 st centuries. In relation to climate change, traditional ecological knowledge has become attractive for the Russian scholars quite recently (Bogoslovskaya \& Krupnik 2013). One might agree with the authors that so far anthropological studies have paid little attention to water and wind, while fire and stone have received some more attention.

The authors of the book under review believe that the environmental experience of the Evenki might be of great use in the practical policy concerning nature conservation. 
"An attempt has been made in the book to show how sensitive and wise the human-nature relations might be and how different the understanding might be of what a landscape is, and how it would be necessary to interact with it" (p. 13). The authors use interdisciplinary approaches to the analysis of these relations, combining methodologies from sociology, ethnography, social anthropology, and cultural geography.

The book is based on the field data gathered during long-term fieldwork in the northern Baikal district of the Republic of Buryatia (Davydov, Simonova), in the Tungokochen and Baunt districts of the Transbaikal region (Brandishauskas), and also in the Sakha (Yakutia) Republic (Sem; the expeditions of 1980-2000). The authors have also used archival sources from the Museum of Anthropology and Ethnography of the Russian Academy of Sciences, the Russian Ethnographic Museum in St. Petersburg, and from a few local archives.

Addressing human-nature relations, the authors use methodological concepts of ecological ethics, cultural landscape among others. These concepts are regarded as modern and dynamic categories rather than static and historically rooted ones. At the same time the authors insist on the importance of the historical perspective in their research.

The book begins with a chapter that deals with Evenki mythology and cosmology. Based on museological, archival, and field materials, Tatyana Sem has reconstructed the Evenki's views on the sun, stars, and stones, and offers an explanation to their understanding. She traces the links of the Evenki worldview with their everyday rituals, shamanic practices, and art. Petroglyphs found on the territory of the mobile Evenki are regarded as ancient narrative structures, which produce strong mental influence on the current mobile Evenki (p. 44). In comparison to the other chapters, this one could be characterised as rooted in the Soviet ethnography of religion and history.

The following chapters of the book are written by young scholars who received their scientific degrees in social anthropology in Aberdeen, Scotland. Their Western education has greatly influenced the themes and methodology in the book, and they are rather new for Russian Siberian studies. One of the methodological tasks of the book was "to liberate the discussion of the problems of human-nature relations in the Baikal Siberia from the received abstract schemes" (p. 174). In fact, traditional historical and ethnographical approaches, as well as postmodernist and phenomenological ones are used in the book. One may find new concepts in the book (in chapter 2 and 4, for example), such as "ethic of minimum", "paper forest ethic", "ethic of domination", "water ethic", and some others. While the concepts of the "ethic of minimum" and the "water ethic" are without doubt meaningful, and therefore useful as a methodological tool, the rest of the concepts seem not to be so successful, if one would understand ethic as a moral principle that governs a person's behaviour or the conducting of an activity.

A special chapter is devoted to the relations of the Transbaikal Evenki with fire. D. Brandishauskas considers these relations to be rooted in economic and religious practices. This part of the book has already been published in English (Brandishauskas 2007). He pays attention to the Evenki manners of managing their landscape, namely to the practice of cultural fire, which brings success in hunting and reindeer-herding. The observation and description of the Evenki's practice of intentional fires is of great value, as not all Evenki groups have it (or we do not know about it). It is obvious that this practice is a form of environmental adaptation to the local landscape. One of the preconditions for intentional fires in the forest is reindeer-herding economy and mobility. The reindeer tread paths through the forest, which also change and cultivate the 
landscape. Burning practice is also known to the Khanty (Adaev 2007). Australian aborigines call their own cultural fires "country cleaning". Australian anthropologist Deborah Rose has mentioned: "It has taken white settlers, scientists and others a very long time to appreciate the fact that indigenous peoples in Australia (and elsewhere) consciously manage their country through the expert use of fire" (Rose et al. 2002: 21). If a comparative approach were used in the chapter, it would help to find out local features in the controlled burning practice and also study the reaction of the national states on cultural fires in the context of today's problems with the forest wild fires.

The authors deal with water and wind as new objects of the anthropology of landscape and anthropology of weather (e.g. Ingold 2007, 2010). They bring in new anthropological perspectives and present new ethnographic data concerning the Evenki of the northern Baikal region. As with fire, these natural phenomena are considered through the optics of everyday "traditional" economic activity in the given landscape.

In spite of the stereotype about Baikal as the purest lake in the world, the local population has experienced coastal water pollution as well as encountered problems concerned with access to water resources for fishing. These problems receive some attention in the book. The authors study what they call Evenki water ethic, and their economic practices of water use, including mobile practices, when water serves as a road and as a barrier. They provide valuable ethnographic observations on everyday life, including Evenki narratives about water and ice.

In scientific literature air is regarded as a mediator and an element within which humans live and act. Since air became an object of anthropological research, landscape has been given a new dimension, where air has become a full-fledged actor of everyday Evenki life. The authors trace how the Evenki calculate the wind movement in order to predict the weather, which is crucially important for conducting their economic activity fishing, hunting, reindeer grazing - as well as for constructing dwellings, organising campsites, and in many other cases.

The Evenki of the Baikal area in Siberia were strongly influenced by Russians and Buryats, which reflects in their culture and language. Unfortunately, there are no comments on this fact in the text. For example, the idea that among the Transbaikal Evenki "the owner of the place is often a dead relative" (p. 123) is not commented upon, while it is likely a Buryat cultural influence (see, e.g., Khandagurova 2008). Speaking about water as medicine, the author gives an example of the northern Baikal Evenki ideas about holy water, but there is no discussion that it is the Russian Orthodox church and popular beliefs that influenced the local Evenki worldview (p. 144). The wind hilos, according to its definition in the book (p. 168) is very likely a deformed name from the hius/hivus wind (a cold wind; the air flows in the river valleys, which increases the influence of low temperatures); the name was brought to Siberia and the Far East by Russians from the north of European Russia, where this kind of wind is known.

Some paragraphs of the text leave an impression of incompleteness and remind us of a sketchy description rather then a full-loaded text. Some published ethnographic data have not deserved the authors' attention. It would also be interesting to trace the Evenki ethnographical cases of the mutual interconnection of the phenomena under consideration; for example, wind and water, water and stone, wind and fire, fire and water.

The book contains extensive new field data, including photographs that enrich the text. It would be of use both for Russian scholars, who may learn about new methodological approaches as well as new research data, and for our foreign colleagues, who know 
the Russian language and study indigenous peoples of the Baikal area of Siberia and neighbouring regions.

This collectively written monograph is a very encouraging example of the study of human-nature relations and as such it gives new perspectives for further work on the topic. The book is available as a free download on the Museum of Anthropology and Ethnography website (http://www.kunstkamera.ru/lib/rubrikator/03/03_03/978-5-88431-303-3/).

Anna Sirina

Leading Research Fellow, Department of Northern and Siberian Studies Institute of Ethnology and Anthropology, Russian Academy of Sciences

\section{References}

Adaev, Vladimir 2007. Traditsionnaia ekologicheskaia kul'tura khantov i nentsev. [Traditional Ecological Culture of the Khanty and Nentsy.] Tyumen: Vektor Buk. Bogoslovskaya, Lyudmila \& Krupnik, Igor (comps.) 2013. Nashi l'dy, snega i vetry / Our Ice, Snow and Winds. Nasledie Beringii / Heritage of Beringia, Issue 2. Moscow \& Washington: Institut naslediia. Available at https://issuu.com/alikulovpavel/ docs/siku_book_all, last accessed on 11 July 2018.

Brandisauskas, Donatas 2007. Symbolism and Ecological Uses of Fire among Orochen-Evenki. Sibirica, Vol. 6, No. 1, pp. 95-109. http://dx.doi.org/10.3167/ sib.2007.060104.

Ingold, Tim 2007. Earth, Sky, Wind and Weather. Journal of the Royal Anthropological Institute, pp. 19-38. http://dx.doi.org/10.1111/j.1467-9655.2007.00401.x.

Ingold, Tim 2010. Footprints Through the Weather-World: Walking, Breathing, Knowing. Journal of the Royal Anthropological Institute, pp. 121-139. http://dx.doi. org/10.1111/j.1467-9655.2010.01613.x.

Khandagurova, Margarita 2008. Obriadnost' kudinskikh i verkholenskikh buriat vo $20 i$ polovine XX veka (basseinov verkhnego $i$ srednego techeniia rek: Kuda, Murino $i$ Kamenka). [Ritualism Among Kudinskie and Verkholenskie Buryats in the Second Part of the 20th Century (in the Upper and Middle Basins of Kuda, Murino, and Kamenka Rivers.] Irkutsk: Amtera.

Rose, Deborah B. \& D'Amico, Sharon \& Daiyi, Nancy \& Deveraux, Kathy \& Daiyi, Margaret \& Ford, Linda \& Bright, April 2002. Country of the Heart: An Indigenous Australian Homeland. Canberra: Aboriginal Studies Press.

Vdovin, Innokenti (ed.) 1976. Priroda i chelovek $v$ religioznykh predstavlenikh narodov Sibiri i Severa (vtoraia polovina XIX-nachalo XX veka). [Nature and Human in the Religious Beliefs of the Peoples of Siberia and the North (Second Half of the 19th-Beginning of the 20th Centuries).] Leningrad: Nauka.

Yamskov, Anatoly 2013. Istoriia stanovleniia i razvitiia otechestvennoi etnoecologii. [The History of the Establishment and Development of National Ethnoecology.] Etnograficheskoe obozrenie, No. 4, pp. 49-64. Available at http://static.iea.ras. ru/articles/Yamskov_2013_History_of_Soviet-Russian_Ethnic_Ecology.pdf, last accessed on 11 July 2018. 

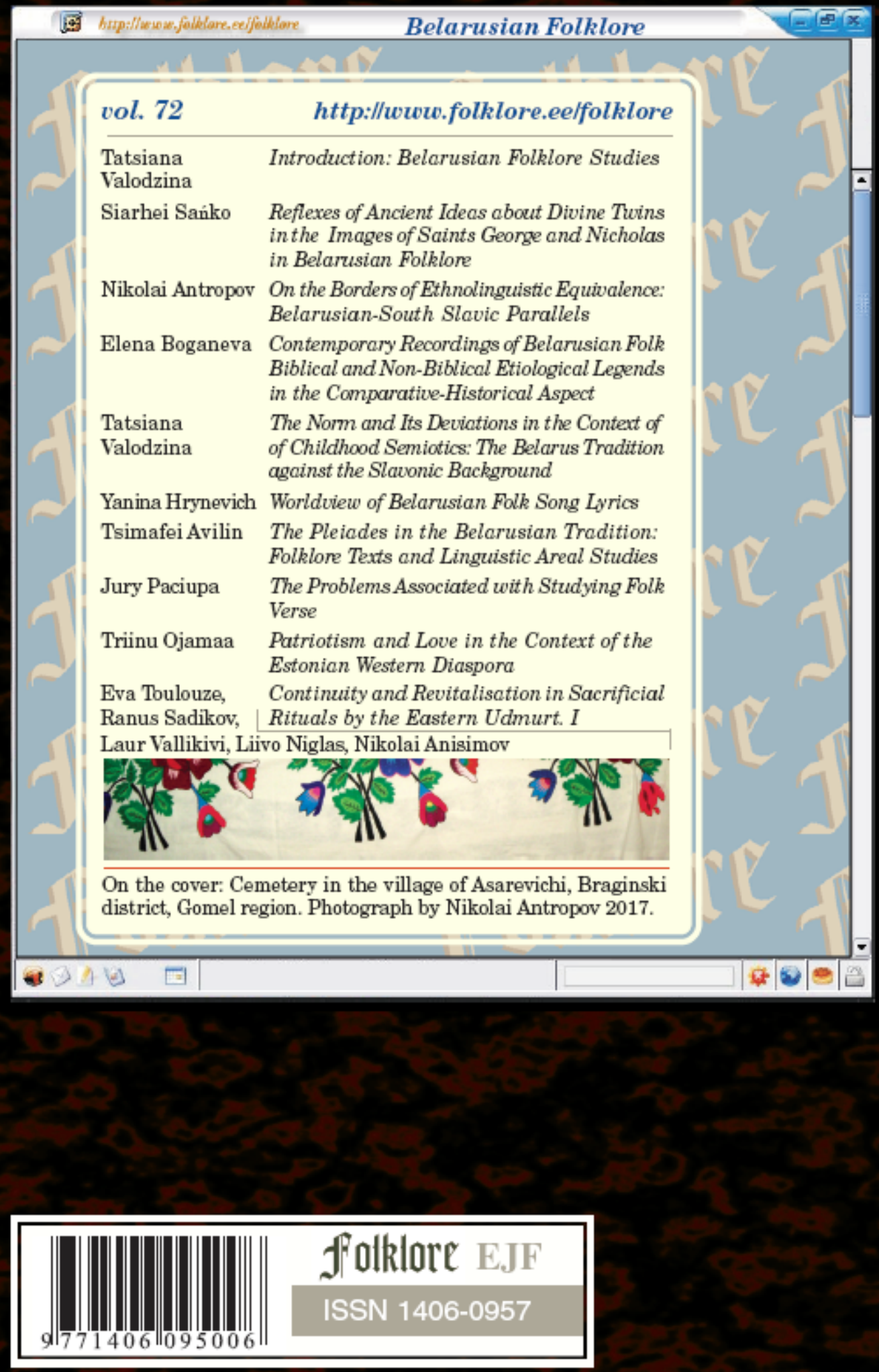